Prepared in cooperation with the Bureau of Land Management

\title{
Hydrogeology of Lower Amargosa Valley and Groundwater Discharge to the Amargosa Wild and Scenic River, Inyo and San Bernardino Counties, California, and Adjacent Areas in Nye and Clark Counties, Nevada
}

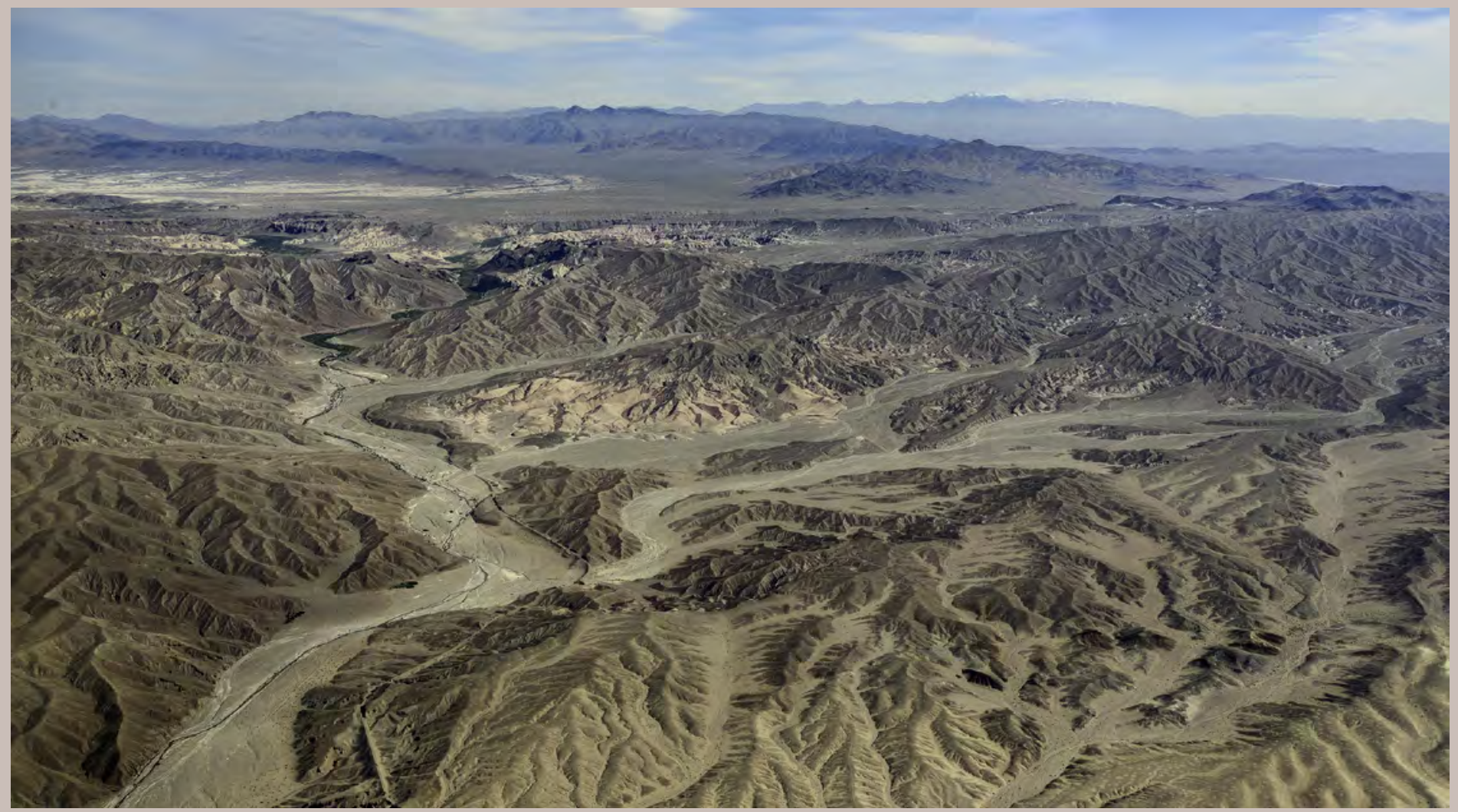

Scientific Investigations Report 2018-5151

U.S. Department of the Interior

U.S. Geological Survey 
Cover photograph: Oblique aerial view looking toward the north from Sperry Wash to the Amargosa Canyon and the southern part of the Tecopa basin. Photograph by Birgitta Jansen and Neal Nurmi, National Park Service, Death Valley National Park, April 6, 2017. 


\section{Hydrogeology of Lower Amargosa Valley and Groundwater Discharge to the Amargosa Wild and Scenic River, Inyo and San Bernardino Counties, California, and Adjacent Areas in Nye and Clark Counties, Nevada}

By Wayne R. Belcher, Donald S. Sweetkind, Candice B. Hopkins, and Megan E. Poff

Prepared in cooperation with the Bureau of Land Management

Scientific Investigations Report 2018-5151 


\title{
U.S. Department of the Interior \\ DAVID BERNHARDT, Acting Secretary
}

\author{
U.S. Geological Survey \\ James F. Reilly II, Director
}

U.S. Geological Survey, Reston, Virginia: 2019

For more information on the USGS - the Federal source for science about the Earth, its natural and living resources, natural hazards, and the environment-visit https://www.usgs.gov or call 1-888-ASK-USGS.

For an overview of USGS information products, including maps, imagery, and publications,

visit https://store.usgs.gov.

Any use of trade, firm, or product names is for descriptive purposes only and does not imply endorsement by the U.S. Government.

Although this information product, for the most part, is in the public domain, it also may contain copyrighted materials as noted in the text. Permission to reproduce copyrighted items must be secured from the copyright owner.

Suggested citation:

Belcher, W.R., Sweetkind, D.S., Hopkins, C.B., and Poff, M.E., 2019, Hydrogeology of Lower Amargosa Valley and groundwater discharge to the Amargosa Wild and Scenic River, Inyo and San Bernardino Counties,

California, and adjacent areas in Nye and Clark Counties, Nevada: U.S. Geological Survey Scientific Investigations Report 2018-5151, 131 p., 1 pl., https://doi.org/10.3133/sir20185151. 


\section{Acknowledgments}

Funding for this study was provided by the Bureau of Land Management under Interagency Agreement L11PG00359. The authors thank The Nature Conservancy and the Amargosa Conservancy for their support of this work by emphasizing its importance to the Bureau of Land Management and providing access to their consultant's work on the hydrology of the Lower Amargosa Valley. The authors thank Susan Sorrells of Shoshone, California, for providing access to the springs at Shoshone and for providing information on the municipal water-supply system. The authors thank Brian Brown of China Ranch, California, for allowing access to China Ranch to gage Willow Creek and for information related to water use at China Ranch. The overall enthusiastic support for this work by local land owners was much appreciated. The authors thank Andy Zdon (consultant to the Amargosa Conservancy) for sharing his data and interpretations, which greatly benefitted this work. Chris Fridrich (retired U.S. Geological Survey) and Jeremy Workman (U.S. Geological Survey) provided draft versions of geologic cross sections of the study area and subsurface interpretations that benefitted this work. Leigh Justet (formerly of the U.S. Geological Survey) provided significant assistance in the conceptual design of the hydrogeochemistry work and the collection of water and rock samples. 


\section{Contents}

Abstract

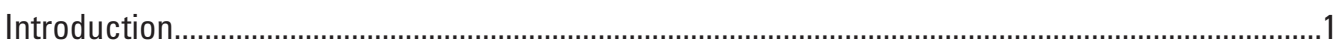

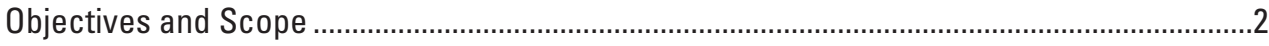

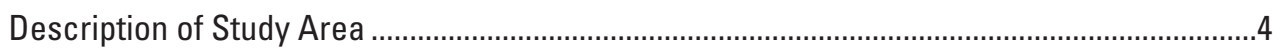

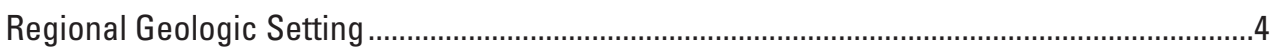

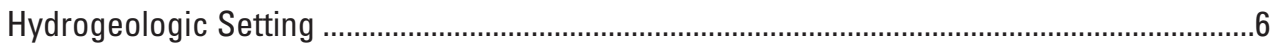

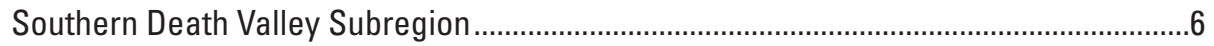

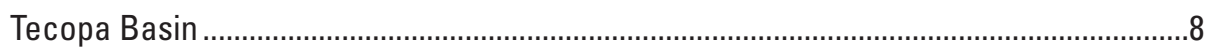

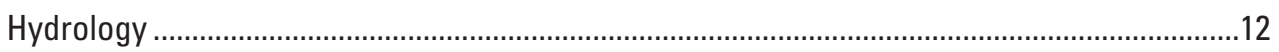

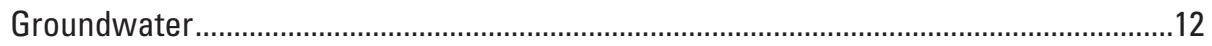

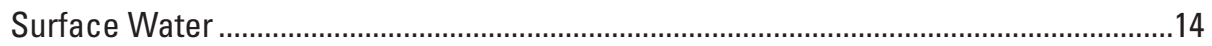

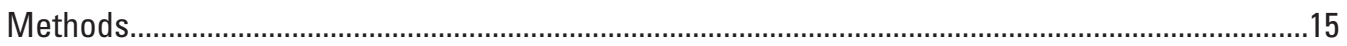

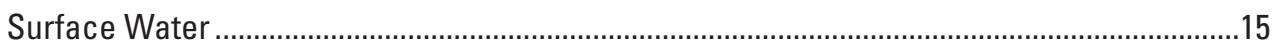

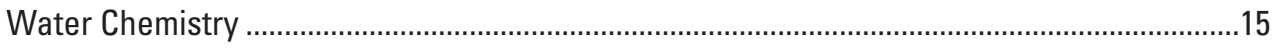

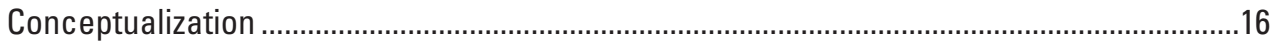

Surface-Water Measurements ...........................................................................................16

Discharge Measurements and Observations at Surface-Water and Discharge Sites ..........18

Shoshone Spring ......................................................................................................

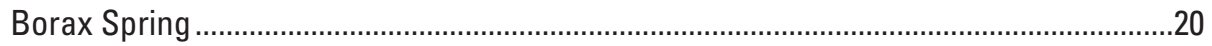

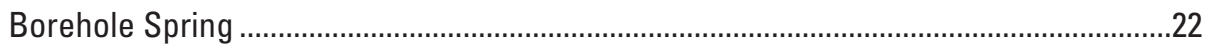

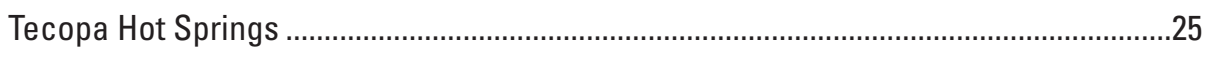

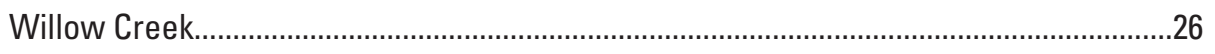

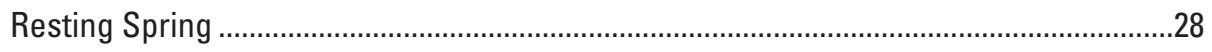

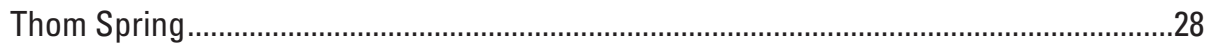

Amargosa Canyon Springs.....................................................................................28

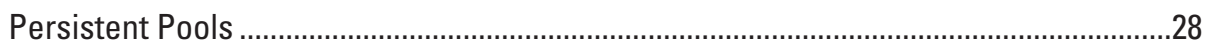

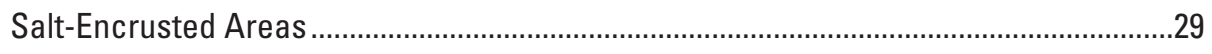

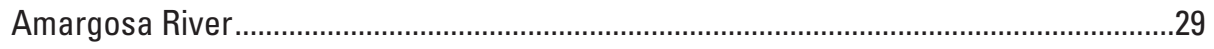

Synoptic Seepage Run on the Amargosa Wild and Scenic River ..........................................

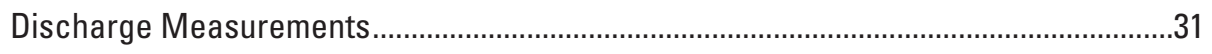

Physical Properties and Alkalinity ...............................................................................

Gains and Losses Along the Amargosa Wild and Scenic River .....................................37

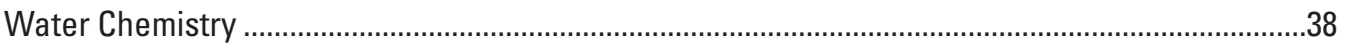

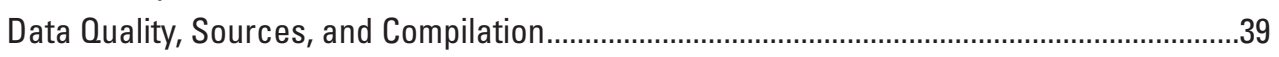

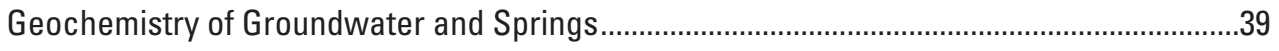

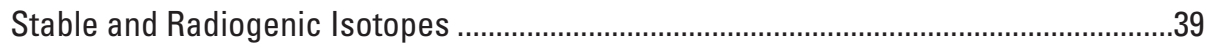

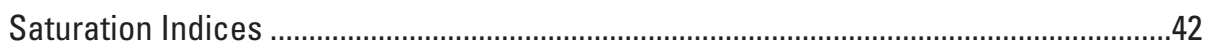

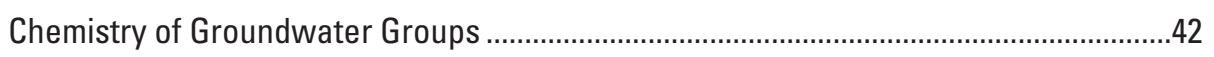

Temperature and Specific Conductance ............................................................. 42

Major lons and Hydrochemical Facies .............................................................4

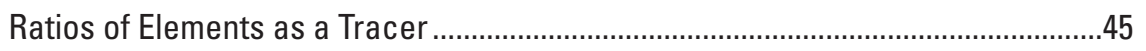

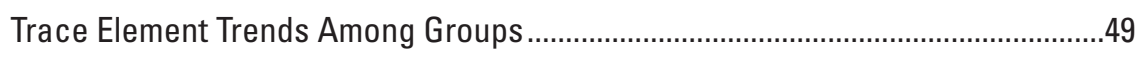

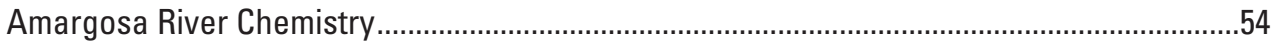

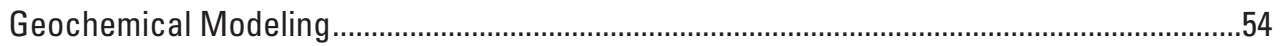




\section{Contents-Continued}

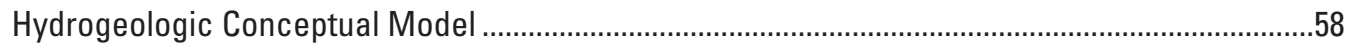

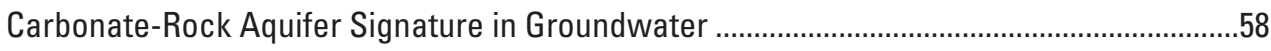

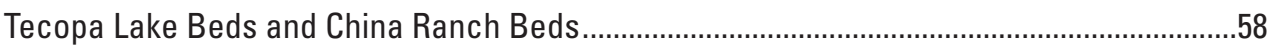

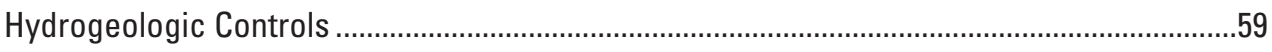

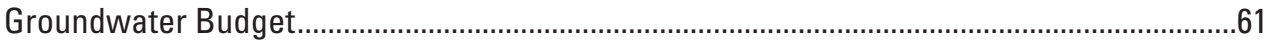

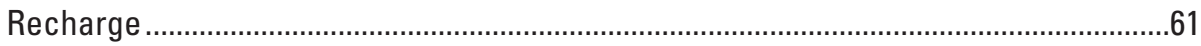

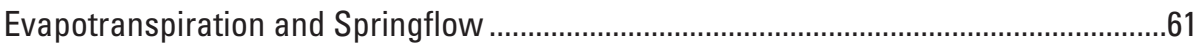

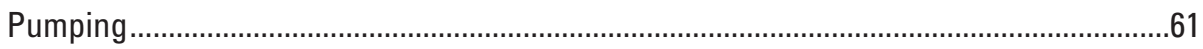

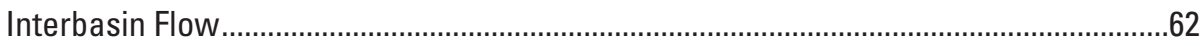

Local Flow Paths and Spring Hydrology .......................................................................62

Regional Carbonate Springs and Seeps ....................................................................62

Tecopa Hills Springs and Seeps ................................................................................65

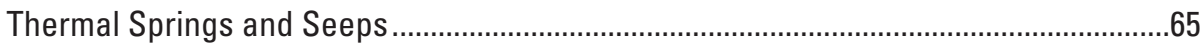

Amargosa Canyon Hillslope Springs and Seeps …………….........................................65

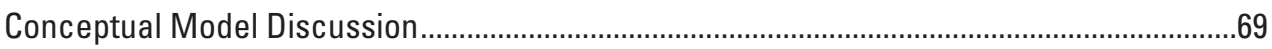

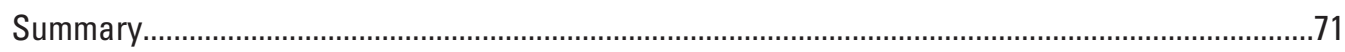

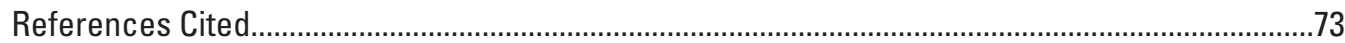

\section{Figures}

1. Map showing locations of the Amargosa Wild and Scenic River, the Lower Amargosa Valley Hydrographic Area, and model domains within the study area, California and Nevada

2. Map showing geology of the Lower Amargosa Valley study area and vicinity, California and Nevada

3. Diagrammatic geologic cross section of the southern Death Valley subregion, California and Nevada

4. Diagrammatic geologic cross sections of the Nopah and Resting Spring Ranges, California

5. Map showing geology of the Tecopa basin in the Lower Amargosa Valley study area, California.

6. Map showing the alluvial/basin-fill aquifer water-level surface and the regional potentiometric surface in the carbonate- and volcanic-rock aquifer in the Lower Amargosa Valley and extra-basin contributing areas, California and Nevada...

7. Map showing surface-water and spring discharge measurement sites along the Amargosa Wild and Scenic River, California ...............................................................17

8. Diagram showing the water-supply system for Shoshone, California ............................19

9. Graph showing discrete discharge measurements at Shoshone Spring concrete

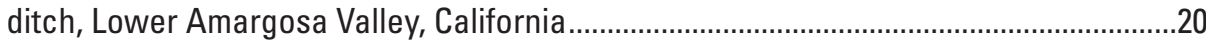

10. Map showing irrigated areas in Shoshone, California ..................................................21

11. Graph showing discrete discharge measurements at Borax Spring, Lower Amargosa Valley, California..

12. Graphs showing discrete and daily discharge measurements at Borehole Spring, Lower Amargosa Valley, California.

13. Graph showing discrete discharge measurements at Tecopa Hot Springs, Lower Amargosa Valley, California... 


\section{Figures-Continued}

14. Graphs showing discrete and daily discharge measurements at Willow Creek, Lower Amargosa Valley, California.

15. Photograph showing the southeast side of the Tecopa Hills in Lower Amargosa Valley, California, and the locations of seeps and springs, as indicated by salt crusts and perennial vegetation.

16. Photograph showing the persistent pools to the north of the Amargosa River at Tecopa, California streamgage in Lower Amargosa Valley.....

17. Photograph showing salt-encrusted area between Borax Spring and the Amargosa River in Lower Amargosa Valley, California, indicating areas of diffuse discharge .......30

18. Map showing seepage run measurement sites and streamgages along the Amargosa River from Shoshone to Dumont Dunes, California .

19. Graph showing discharge recorded on February 27, 2014, at U.S. Geological Survey streamgages Amargosa River at Tecopa, California, and Amargosa River above China Ranch Wash near Tecopa, California.....

20. Graphs showing stream stage measurements over time on February 27, 2014, at seepage run sites AR11, AR16, and AR21, along the Amargosa River, California

21. Graphs showing measurements made for specific conductance, temperature, and alkalinity, at seepage run sites along the Amargosa River downstream from Shoshone ditch, on February 27-28, 2014.

22. Graph showing discharge measurements made at seepage run sites along the Amargosa River downstream from Shoshone ditch, on February 27-28, 2014

23. Map showing location and geochemical group for selected representative waterchemistry samples in the Lower Amargosa Valley and extra-basin contributing areas, California and Nevada

24. Graphs showing delta deuterium versus delta oxygen-18 for groundwater, surfacewater, and precipitation samples plotted on global and local meteoric water lines at a normal scale and an enlarged scale, Lower Amargosa Valley and extra-basin contributing areas, California and Nevada

25. Graph showing water temperature versus specific conductance for groundwater samples in the Lower Amargosa Valley and extra-basin contributing areas, California and Nevada

26. Trilinear diagram showing representative water sample groups from the Lower Amargosa Valley and extra-basin contributing areas, California and Nevada

27. Graph showing chloride concentration versus strontium to calcium ratios in groundwater samples from the Lower Amargosa Valley and extra-basin contributing areas, California and Nevada

28. Graphs showing specific conductance versus sodium-to-calcium ratios plotted at a normal scale and an enlarged scale, for groundwater samples from the Lower Amargosa Valley and extra-basin contributing areas, California and Nevada

29. Graphs showing fluoride, lithium, and boron concentrations versus arsenic concentration plotted at a normal scale and an enlarged scale, for groundwater samples from the Lower Amargosa Valley and extra-basin contributing areas, California and Nevada

30. Graphs showing boron concentration versus strontium to calcium ratios plotted at a normal scale and an enlarged scale, for groundwater samples from the Lower Amargosa Valley and extra-basin contributing areas, California and Nevada......

31. Map showing feasible modeled flow paths to the Lower Amargosa Valley from extra-basin contributing areas, California and Nevada. 


\section{Figures-Continued}

32. Map showing inferred pathways of groundwater flow in relation to geology and structural controls, to the Lower Amargosa Valley from extra-basin contributing areas, California and Nevada....

33. Schematic cross section showing generalized groundwater flow from the carbonate-rock aquifer to carbonate springs and seeps on the west side of the Tecopa basin, Lower Amargosa Valley, California.

34. Schematic cross section showing generalized groundwater flow from the carbonate-rock aquifer to springs and seeps on the east side of the Tecopa Hills, Lower Amargosa Valley, California

35. Schematic cross section showing generalized groundwater flow from siliciclastic rocks to thermal springs and the Amargosa River, Lower Amargosa Valley, California 67

36. Schematic cross section showing generalized groundwater flow from the carbonate-rock aquifer to hillslope springs and seeps on the east side of Amargosa Canyon, Lower Amargosa Valley, California

37. Map showing conceptualization of the groundwater flow system in carbonate rocks, and unconsolidated alluvial deposits and sedimentary rocks, in the Tecopa basin, Lower Amargosa Valley, California.

\section{Tables}

1. Discrete discharge measurements at Shoshone Spring concrete ditch

(U.S. Geological Survey site 355846116161901)

2. Discrete discharge measurements at Borax Spring (U.S. Geological Survey site 355317116152901).

3. Discrete discharge measurements at Borehole Spring (U.S. Geological Survey site 10251290).

4. Discrete discharge measurements at Tecopa Hot Springs (U.S. Geological Survey site 355219116135901 )

5. Discrete discharge measurements at Willow Creek (U.S. Geological Survey site 10251335).

6. Annual mean discharge for Amargosa River at Tecopa, California (U.S. Geological Survey site 10251300).

7. Annual mean discharge for Amargosa River above China Ranch Wash near Tecopa, California (U.S. Geological Survey site 10251330).....

8. Stream discharge and physical-property measurements from synoptic seepage run sites along the Amargosa Wild and Scenic River, California

9. Water chemistry of selected samples from the Lower Amargosa Valley and extrabasin contributing areas, California and Nevada

10. Selected chemistry of representative samples used in geochemical analysis and modeling, Lower Amargosa Valley and extra-basin contributing areas, California and Nevada.

11. Ranges of selected chemical parameters by water group, Lower Amargosa Valley and extra-basin contributing areas, California and Nevada

12. Saturation indices for selected minerals for groundwater samples, Lower Amargosa Valley and extra-basin contributing areas, California and Nevada. 


\section{Tables-Continued}

13. Geochemical modeling results for attempted flow paths to the Lower Amargosa Valley from extra-basin contributing areas, California and Nevada.

14. Water budget components for the Lower Amargosa Valley, California ............................57

15. Observations and characteristics of springs in the Tecopa basin, Lower Amargosa Valley, California

\section{Plate}

[Available online only at https://doi.org/10.3133/sir20185151/.]

1. Significant hydrogeologic and hydrologic features and sampling locations, Tecopa basin and adjacent areas, California

\section{Conversion Factors}

U.S. customary units to International System of Units

\begin{tabular}{lcl}
\hline \multicolumn{1}{c}{ Multiply } & By & \multicolumn{1}{c}{ To obtain } \\
\hline foot $(\mathrm{ft})$ & Length & meter $(\mathrm{m})$ \\
mile $(\mathrm{mi})$ & 0.3048 & kilometer $(\mathrm{km})$ \\
\hline & 1.609 & \\
\hline square mile $\left(\mathrm{mi}^{2}\right)$ & Area & square kilometer $\left(\mathrm{km}^{2}\right)$ \\
\hline & 2.590 & \\
\hline acre-foot $($ acre-ft) & Volume & cubic meter $\left(\mathrm{m}^{3}\right)$ \\
\hline & $1,233.48$ & cubic meter per second $\left(\mathrm{m}^{3} / \mathrm{s}\right)$ \\
\hline cubic foot per second $\left(\mathrm{ft}{ }^{3} / \mathrm{s}\right)$ & Flow rate & cubic meter per year $\left(\mathrm{m}^{3} / \mathrm{yr}\right)$ \\
cubic foot per second $\left(\mathrm{ft}^{3} / \mathrm{s}\right)$ & 0.02832 & meter per second $(\mathrm{m} / \mathrm{s})$ \\
foot per second $(\mathrm{ft} / \mathrm{s})$ & 893,000 & cubic meter per year $\left(\mathrm{m}^{3} / \mathrm{yr}\right)$ \\
acre-foot per year $(\mathrm{acre}-\mathrm{ft} / \mathrm{yr})$ & 0.3048 & \\
\hline
\end{tabular}

International System of Units to U.S. customary units

\begin{tabular}{lll}
\hline \multicolumn{1}{c}{ Multiply } & By & \multicolumn{1}{c}{ To obtain } \\
\hline cubic meter $\left(\mathrm{m}^{3}\right)$ & 0.00081 & cubic foot $\left(\mathrm{ft}^{3}\right)$ \\
cubic meter per day $\left(\mathrm{m}^{3} / \mathrm{d}\right)$ & 0.00081 & acre-foot per day $($ acre-ft/d) \\
cubic meter per year $\left(\mathrm{m}^{3} / \mathrm{yr}\right)$ & 0.00081 & acre-foot per year $(\mathrm{acre}-\mathrm{ft} / \mathrm{yr})$ \\
meter $(\mathrm{m})$ & 3.2808 & foot $(\mathrm{ft})$ \\
\hline
\end{tabular}

Temperature in degrees Celsius $\left({ }^{\circ} \mathrm{C}\right)$ can be converted to degrees Fahrenheit $\left({ }^{\circ} \mathrm{F}\right)$ as follows:

$$
{ }^{\circ} \mathrm{F}=\left(1.8 \times{ }^{\circ} \mathrm{C}\right)+32 .
$$

Temperature in degrees Fahrenheit $\left({ }^{\circ} \mathrm{F}\right)$ can be converted to degrees Celsius $\left({ }^{\circ} \mathrm{C}\right)$ as follows:

$$
{ }^{\circ} \mathrm{C}=\left({ }^{\circ} \mathrm{F}-32\right) / 1.8 \text {. }
$$




\section{Datums}

Horizontal coordinate information is referenced to the North American Datum of 1927 (NAD 27). Vertical coordinate information is referenced to the National Geodetic Vertical Datum of 1929 (NGVD 29).

Altitude, as used in this report, refers to distance above the vertical datum.

\section{Water-Quality Units}

Specific conductance is given in microsiemens per centimeter at 25 degrees Celsius $(\mu \mathrm{S} / \mathrm{cm}$ at $\left.25^{\circ} \mathrm{C}\right)$.

Concentrations of chemical constituents in water are given in either milligrams per liter (mg/L) or micrograms per liter $(\mu \mathrm{g} / \mathrm{L})$.

Stable-isotope (oxygen-18, deuterium, carbon-13, and strontium-87) concentrations are given in units of per mil (per thousand). Tritium concentrations are reported as tritium units (TU), where $1 \mathrm{TU}=3.22$ picocuries per liter.

Carbon-14 concentrations are expressed as percent modern carbon (pMC).

\section{Abbreviations}

$\begin{array}{ll}\text { AWSR } & \text { Amargosa Wild and Scenic River } \\ \text { Calif. } & \text { California } \\ \text { DVRFS } & \text { Death Valley regional groundwater flow system } \\ \text { ET } & \text { evapotranspiration } \\ \text { GMWL } & \text { Global Meteoric Water Line } \\ \text { LAV } & \text { Lower Amargosa Valley } \\ \text { LMWL } & \text { Local Meteoric Water Line } \\ \text { NeV. } & \text { Nevada } \\ \text { NWIS } & \text { National Water Information System } \\ \text { NWQL } & \text { National Water Quality Laboratory } \\ \text { USGS } & \text { U.S. Geological Survey }\end{array}$




\title{
Hydrogeology of Lower Amargosa Valley and Groundwater Discharge to the Amargosa Wild and Scenic River, Inyo and San Bernardino Counties, California, and Adjacent Areas in Nye and Clark Counties, Nevada
}

\author{
By Wayne R. Belcher, Donald S. Sweetkind, Candice B. Hopkins, and Megan E. Poff
}

\section{Abstract}

In 2009, Congress designated certain reaches of the Amargosa River in Inyo County, California between the town of Shoshone and Dumont Dunes as a Wild and Scenic River. As part of the management of the Amargosa Wild and Scenic River, the Bureau of Land Management cooperated with the U.S. Geological Survey to assess the surface and groundwater resources of the Tecopa basin. Groundwater is the primary source of water to the perennial reaches of the Amargosa River. The U.S. Geological Survey studied the surface and groundwater systems in the basin, and assessed the sources and volume of groundwater discharging into the perennial reaches of the Amargosa Wild and Scenic River.

The springs within the Tecopa basin (and the greater Lower Amargosa Valley Hydrographic Area) can be generally grouped by spring type and geographic location. There are four types of groundwater discharge points in the Tecopa basin-regional carbonate-rock springs and seeps, Tecopa Hills springs and seeps, thermal springs and seeps, and Amargosa Canyon hillslope springs and seeps. Results of chemical analysis indicate that water from all of these springs in the Lower Amargosa Valley and particularly in the Tecopa basin, is sourced in the carbonate-rock aquifer, with a local component of recharge. Groundwater is recharged in the Spring Mountains and moves through and around the Nopah and Resting Spring Ranges and into the Tecopa basin. A small (less than 1 cubic foot per second $\left[\mathrm{ft}^{3} / \mathrm{s}\right]$ or 500 acre-feet per year) component of flow from the Amargosa Desert moves through the river channel alluvium and basin fill from the north.

The location and type of spring appear to be controlled by the geology and geologic structure of the Lower Amargosa Valley. The regional springs (such as Shoshone and Borax Springs) and associated seeps tend to occur along the west side of the basin whereas other carbonate-rock aquifer springs discharge from adjacent mountain ranges, such as the Resting Spring Range, and as a result of low-permeability barriers, such as the Tecopa Hills. The thermal springs and seeps discharge from an area near the town of Tecopa, California. The Amargosa Canyon hillslope springs and seeps discharge directly into the river. Salt-crusted soils adjacent to the river indicate additional areas of diffuse discharge where groundwater is being evaporated.

Perennial flow in the main channel of the Amargosa River appears to originate in an area of thermal springs near Tecopa. Persistent groundwater-fed pools begin to appear along the river channel just to the south of the Tecopa Hills. Flow between these pools is evident, but difficult to measure. During the synoptic seepage measurement survey in February 2014, flow in the Amargosa River at the Tecopa streamgage (U.S. Geological Survey site 10251300, Amargosa River at Tecopa, California) was approximately $1 \mathrm{ft}^{3} / \mathrm{s}$. Just to the south of the Tecopa streamgage, a line of cooler water springs (the Amargosa Canyon hillslope springs) emerges east of the river channel and continues for approximately 1 mile along the Amargosa Canyon wall. At the end of the spring reach, the flow in the river increased to just over $4 \mathrm{ft}^{3} / \mathrm{s}$. Flow then decreased to approximately $3 \mathrm{ft}^{3} / \mathrm{s}$ at the confluence of Willow Creek, approximately 3.5 miles downstream. Downstream from the confluence of Willow Creek, the river consistently loses water and was dry just north of Dumont Dunes during the February 2014 synoptic seepage measurement survey.

\section{Introduction}

The Amargosa River traverses approximately 150 miles (mi) of Nevada and California and is the only free-flowing river in the western part of the Mojave Desert near Death Valley (fig. 1). The river originates in the northwestern part of the Nevada National Security Site (NNSS) and its course continues southward through Oasis Valley and the Amargosa Desert toward Dumont Dunes, in California. After passing Dumont Dunes, the river course turns west and then north into Death Valley, terminating in the Badwater basin. 
The only perennial reaches of the river occur near Beatty, Nevada (Nev.) and Tecopa, California (Calif.), where the river is fed by spring discharge (Faunt, D'Agnese, and O'Brien, 2010). The river, its tributaries, and nearby springs and seeps support biologically rich wetlands, riparian woodlands, mesquite bosques, and alkaline meadows that harbor a large part of the region's biodiversity.

In 2009, Congress designated segments of the Amargosa River from Shoshone, Calif., to Dumont Dunes as part of the National Wild and Scenic Rivers System (fig. 1; National Wild and Scenic Rivers System, 2015). In order to fulfill the requirements of the National Wild and Scenic Rivers System Act, the Bureau of Land Management must develop a land monitoring and management plan for the wild and scenic parts of the Amargosa River, hereafter called the Amargosa Wild and Scenic River (AWSR).

Perennial flow in the AWSR is supplied by groundwater inflow to the river channel and by discharge from perennial springs and seeps along the river corridor (fig. 1; Faunt, D'Agnese, and O'Brien, 2010). Although a fraction of the perennial flow in the river may be supported by locally sourced groundwater (from direct precipitation, mountain runoff, and/or nearby higher-altitude recharge), previous hydrologic and geochemical data indicate that much of this flow is derived from groundwater that has recharged in the Spring Mountains, more than $40 \mathrm{mi}$ from the Amargosa River (Malmberg, 1967; Steinkampf and Werrell, 2001; Belcher and Sweetkind, 2010). Groundwater originating as surface recharge in the Spring Mountains and other mountain highlands (to a lesser degree) is assumed to move through consolidated carbonate- and volcanic-rock aquifers and basin fill, both as northeast-southwest flow beneath Pahrump Valley or as southward flow beneath the Amargosa Desert, to discharge sites in and near the river as part of a regional groundwater flow system (Harrill and Prudic, 1998; Belcher and Sweetkind, 2010).

The primary region of interest to this study lies within or adjacent to the Lower Amargosa Valley Hydrographic Area (Harrill and others, 1988), hereafter referred to as the Lower Amargosa Valley or LAV. Hydrographic areas are based primarily on surface-water divides and often used by state agencies as the basis for water-resource management. The LAV includes groundwater discharge sites near Shoshone and Tecopa, Calif. (generally referred to as the Tecopa basin), and the reach of the Amargosa River from Eagle Mountain on the north to a point midway along the Amargosa Canyon to the south (fig. 1). The remaining free-flowing part of the Amargosa River in the Amargosa Canyon to the Dumont Dunes lies just south of the LAV boundary (fig. 1).

The recent and proposed groundwater withdrawals in the region have the potential to impact perennial flow in the AWSR. Most groundwater pumping in the area occurs in Pahrump Valley and southern Amargosa Desert where the water is used for domestic and agricultural purposes (San Juan and others, 2010). There is also local domestic pumping at the Tecopa Heights area to the east of Amargosa Canyon, a single periodically pumped well in Chicago Valley, and two domestic pumping wells in the China Ranch area. Increased urbanization of Pahrump Valley and the potential for solar energy development in the Amargosa Desert and Pahrump Valley indicate the possibility of increased groundwater usage. Recent pumping and additional groundwater development have the potential to adversely impact spring discharge in the LAV and reduce flow to the AWSR.

\section{Objectives and Scope}

The objective of this study is to refine the conceptual understanding of the groundwater flow system within and surrounding the LAV and to better understand groundwater discharge contributions to the AWSR. An improved understanding of the groundwater flow system in the study area will aid resource managers with decisions regarding monitoring and management to mitigate potential influences on groundwater flow to the AWSR.

The scope of work completed to meet the project's objectives included the following tasks:

Data compilation: This task included compilation and evaluation of existing GIS, geologic, hydrologic, and geochemical data.

Hydrogeologic framework studies: This task entailed an understanding of the principal hydrogeologic units, bedrock architecture of the LAV, and geologic structures that may affect or influence regional groundwater flow. The work included (a) collecting surface geophysical information to better define the bedrock structure and thickness of basin fill, and identifying principal geologic units present in the subsurface, and (b) constructing geologic cross sections to illustrate the subsurface configuration of bedrock and basinfill aquifers and identifying geologic structures that affect or influence regional groundwater flow.

Hydrologic studies: This task characterized the surfacewater and groundwater hydrologic systems and defined the nature and magnitude of surface-water-groundwater interactions. This work included (a) measuring the discharge and other physical characteristics of selected springs in the study area, (b) conducting multiple discharge measurements over a short period of time (a synoptic seepage measurement survey or seepage "run") to define gaining and losing reaches in the AWSR and to quantify groundwater discharge directly into the river, and (c) making qualitative observations of areas of diffuse discharge where measurements were not possible.

Geochemical analysis and modeling: This task identified the chemical types of waters sampled at springs, in the Amargosa River, and from potential source areas. In addition to existing data compiled as part of task 1 from springs, wells, and surface-water locations, additional geochemical samples were collected from selected sites along the Amargosa River; no additional samples were collected from springs or wells.

Geochemical modeling was done using these data to evaluate the relation between source and discharge points along inferred groundwater flow paths. 


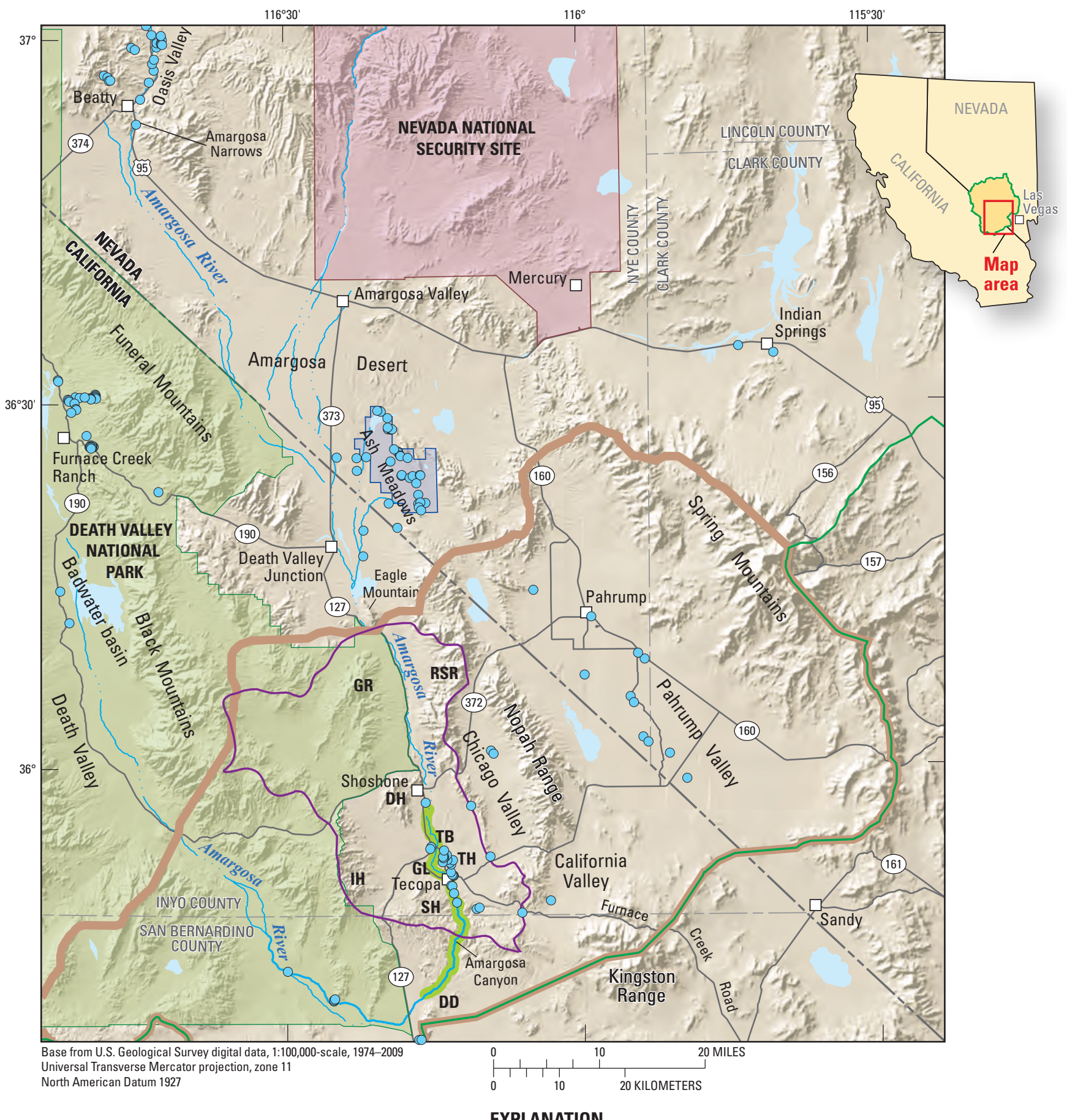

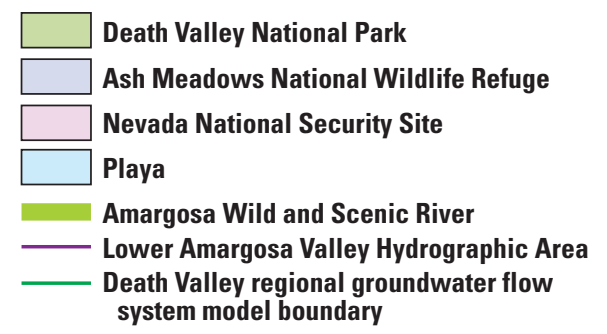

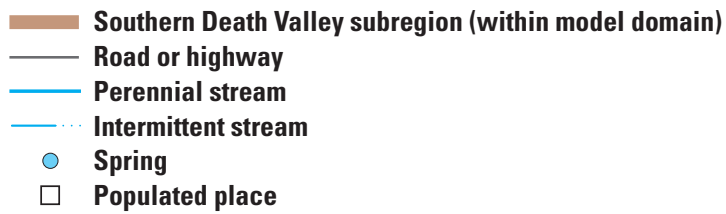

Abbreviations: DD, Dumont Dunes; DH, Dublin Hills; GL, Grimshaw Lake GR, Greenwater Range; IH, Ibex Hills; RSR, Resting Spring Range; SH, Sperry Hills; TB, Tecopa basin; TH, Tecopa Hills

Figure 1. Locations of the Amargosa Wild and Scenic River, the Lower Amargosa Valley Hydrographic Area, and model domains within the study area, California and Nevada. 
Conceptualization of the system: Interpretations were made using the data obtained during this study, as well as previously collected hydrologic and geologic information, to develop an overall conceptualization of the LAV groundwater system.

\section{Description of Study Area}

The Amargosa River originates in the mountains of southwestern Nevada and flows south and west, terminating in the sinks and playas of Death Valley (fig. 1). The Amargosa River drainage basin occupies approximately two-thirds of the 8,500-square mile Death Valley watershed and has the largest drainage area of any stream discharging into Death Valley (Grasso, 1996). Despite the large drainage area, most of the Amargosa River and its tributaries are ephemeral. Perennial reaches of the Amargosa River occur where groundwater is forced to the surface by shallow low-permeability rocks in the Amargosa Narrows near Beatty, Nev., and where springflow provides water to the river in the LAV and downstream in the Amargosa Canyon (fig. 1).

The primary focus area of this study is within or adjacent to the LAV (fig. 1) including the Tecopa basin, which in this report refers to the 200-square mile roughly triangular region that includes the towns of Shoshone and Tecopa and is bounded by the Dublin and Ibex Hills to the west, the Resting Spring and Nopah Ranges to the east and the Sperry Hills to the south (fig. 1). The town of Shoshone forms the apex of the study area, which includes the Amargosa Canyon through the Sperry Hills to the southern outlet of the canyon north of the Dumont Dunes (fig. 1). Because the major springs in the Tecopa basin have a regional component of flow from outside the LAV, this study also includes data from a broader area including Pahrump, Chicago, and California Valleys, parts of southern Death Valley, and the southern part of the Amargosa Desert (fig. 1). This broad region surrounding and including the LAV is referred to in this report as the LAV study area or study area (fig. 1).

\section{Regional Geologic Setting}

The LAV study area lies in the southern part of the Basin and Range physiographic province within the Great Basin (Fenneman, 1931; fig. 2). In the northeast part of the study area, the pre-Cenozoic consolidated-rock section is similar to that exposed throughout the southern Great Basin, consisting of an up to 15,000-foot-thick sequence of Paleozoic carbonate rocks overlying a 7,200-foot-thick consolidated-rock section of Upper Proterozoic and Lower Cambrian siliciclastic rock (fig. 2; Burchfiel and others, 1982; Dettinger and others, 1995; Plume, 1996; Page, Dixon, and others, 2005). In this region, carbonate rocks are prominently exposed in the Spring Mountains, the Nopah Range, and the
Resting Spring Range (fig. 2) and are inferred to be present beneath Cenozoic basin fill in many of the valleys (Sweetkind, Dickerson, and others, 2001; Page and others, 2011). In the southwest part of the study area, the combined effects of Cenozoic deformation, uplift, and erosion have removed the Paleozoic carbonate rocks, resulting in mountain-block uplifts where Cenozoic rocks unconformably overlie Proterozoic siliciclastic and crystalline rocks (fig. 2). The consolidated rocks in this area include a 7,200-foot-thick section of Neoproterozoic siliciclastic rocks, underlain by a 7,200-footthick Neoproterozoic and Mesoproterozoic sequence of mainly siliciclastic strata with two thick dolomite units, collectively named the Pahrump Group (Hewitt, 1956), and underlain by crystalline basement rocks, including granite and gneiss. The southwest part of the study area also features plutonic rocks, mostly Cenozoic in age (fig. 2; Workman, Menges, Page, Taylor, and others, 2002).

The LAV lies at the southern terminus of the carbonaterock province of the Great Basin, within which Paleozoic carbonate rocks form an extensive hydrogeologic unit that is inferred to underlie the entire eastern two-thirds of the Great Basin (Plume, 1996; Harrill and Prudic, 1998; Heilweil and Brooks, 2011).

Cenozoic rocks of the LAV study area consist of a wide variety of rock types, including Miocene and Pliocene volcanic rocks, consolidated older Cenozoic basin-fill rocks, and overlying unconsolidated basin-fill deposits. Volcanic rocks in the LAV study area are almost entirely associated with the central Death Valley volcanic field, which lies to the west of Shoshone, Calif., and to the southwest of Death Valley Junction (fig. 2). Volcanic rocks that have erupted from this volcanic field include basaltic to rhyolitic lava flows, rare welded tuffs, and nonwelded tuffs that were derived from several localized volcanic centers (Wright and others, 1991).

Consolidated Cenozoic rocks in the southern Death Valley subregion (D'Agnese and others, 1997) range in age from Oligocene to late Miocene and were deposited before, during, and after regional extension and volcanism in a variety of continental depositional environments (Sweetkind, Fridrich, and Taylor, 2001; Fridrich and Thompson, 2011). The distribution and character of Cenozoic sedimentary rocks in the LAV study area are influenced by the timing of basin opening, the magnitude and rate of uplift of the surrounding ranges, and the extent of drainage integration between basins (Fridrich and Thompson, 2011). Consolidated Cenozoic rocks include fine- to coarse-grained sedimentary rocks of variable sorting and bedding characteristics, including alluvial and fluvial conglomerate and sandstone, lacustrine limestone, gypsum-bearing siltstones and sandstones, and tuffaceous sedimentary rocks and reworked tuffs (Sweetkind, Fridrich, and Taylor, 2001; Fridrich and Thompson, 2011; Taylor and Sweetkind, 2014). Consolidated Neogene sedimentary rocks are often buried by younger deposits, but are exposed in the Sperry Hills to the south of the Tecopa basin (fig. 2). 


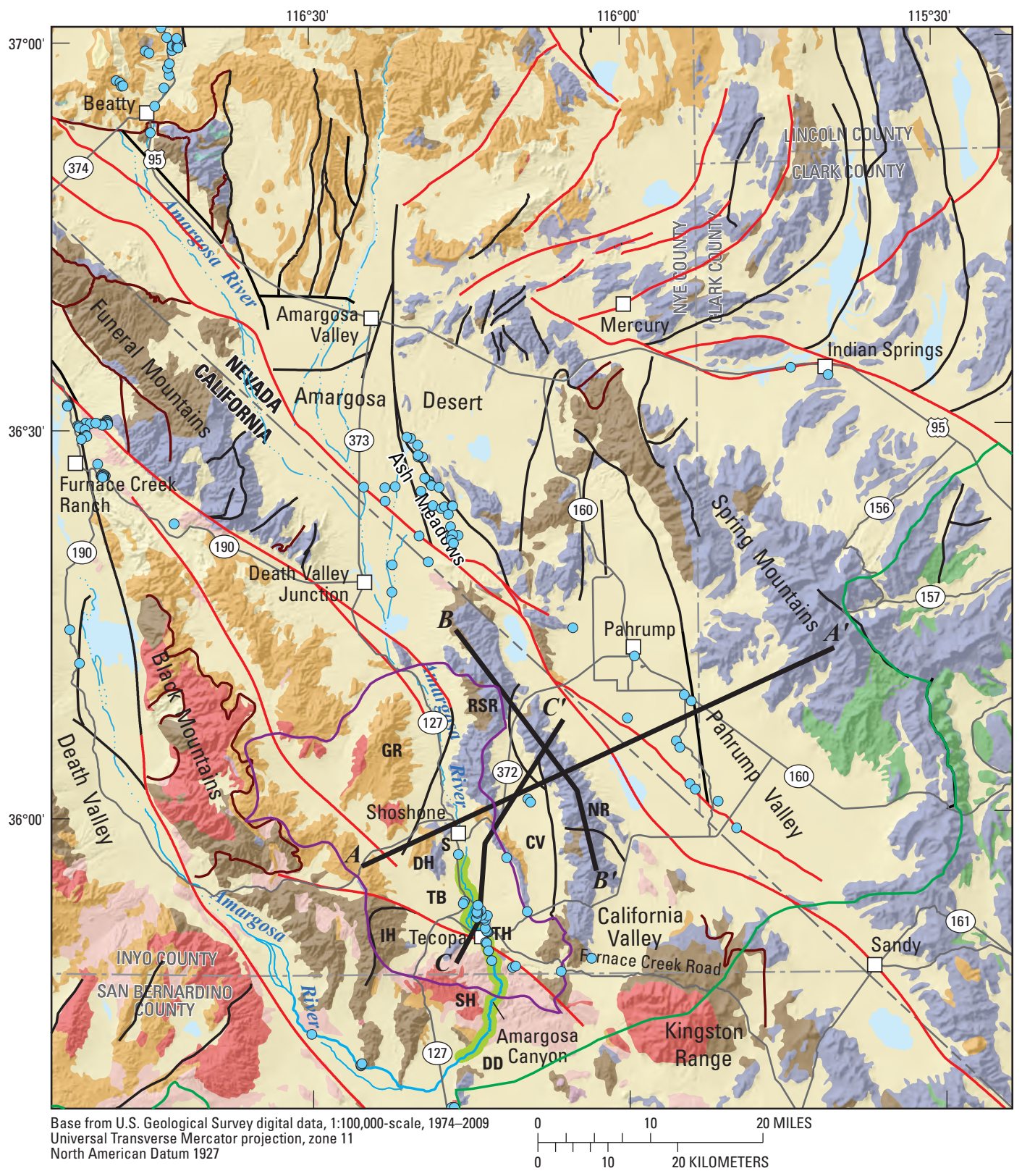

EXPLANATION

Map units (after Raines and others, 2003; Saucedo and others, 2000)

Amargosa Wild and Scenic River

Playa deposits

Quaternary alluvium and valley fill

Cenozoic volcanic rocks, undivided

Cenozoic sedimentary rocks, undivided

Mesozoic sedimentary rocks

Paleozoic carbonate rocks

Proterozoic and Lower Cambrian siliciclastic and crystalline rocks Intrusive rocks, undivided

Cenozoic geologic structures (after Potter and others, 2002)

Strike-slip fault

Normal fault

Low-angle detachment fault

Figure 2. Geology of the Lower Amargosa Valley study area and vicinity, California and Nevada. 
Pliocene deposits consist of alluvial and fluvial conglomerate and sandstone, along with widespread carbonate rocks and clays deposited in playas, marshlands, ponds, and floodplains (Hay and others, 1986). Pliocene to Pleistocene limestone and dolomite seepage mounds formed at groundwater discharge sites (Denny and Drewes, 1965; Hay and others, 1986), and Pleistocene lake beds occupy the surface of the Tecopa basin (hereafter referred to as Tecopa lake beds). Unconsolidated Quaternary deposits include fineto coarse-grained alluvial fan and stream channel deposits, spring discharge deposits, and eolian deposits, as both widespread sand sheets and more localized dunes (Denny and Drewes, 1965; Workman, Menges, Page, Taylor, and others, 2002). In general, coarse alluvial deposits occur adjacent to mountain fronts, and these deposits grade basinward to finer-grained materials. The thickness of these gravels and sand aquifers is variable, generally tens to hundreds of meters (Oatfield and Czarnecki, 1989, 1991; Taylor and Sweetkind, 2014).

Cenozoic deformation of the region is characterized by a variety of structural patterns that overlap in space and time: (1) basin-range extension, (2) local extreme extension along detachment faults that have gentle dips, (3) development of discrete strike-slip faults and transtensional basins in the Walker Lane belt, and (4) Cenozoic volcanism that preceded and accompanied regional extension. North of the Spring Mountains, and northward into southern and central Nevada, late Cenozoic extensional deformation was dominated by movement along north- to northeast-striking normal faults related to development of the characteristic basin and range structure and associated topography of the southern Great Basin (fig. 2; Plume, 1996; Page, Dixon, and others, 2005). The Spring Mountains are relatively unextended and are preserved as a high-standing structural block (fig. 2; Page, Lundstrom, and others, 2005). West and south of the Spring Mountains, extension is spatially variable, but generally of greater magnitude than in the northern part of the region (fig. 2). The block-faulted range blocks of the Nopah Range and Resting Spring Range and the intervening Stewart, Chicago, and California Valleys are the result of large-scale down-to-the-west block faulting and related eastward tilting (Burchfiel and others, 1983; Snow and Wernicke, 2000; Workman, Menges, Page, Ekren, and others, 2002). West of the Resting Spring Range and the Tecopa basin, extreme extension has occurred along gently to moderately dipping, large-offset extensional detachment faults and has completely removed the Paleozoic carbonate-rock section, resulting in a stratigraphic succession where Cenozoic rocks tectonically overlie Proterozoic basement rocks (Wright and others, 1999; Snow and Wernicke, 2000). The Tecopa basin overlies the boundary between the region of rotated range blocks containing Paleozoic carbonate rocks and the highly extended terrane to the west (fig. 2). The northwest-trending Walker Lane belt (Stewart, 1988; Stewart and Crowell, 1992) transects the LAV study area. The Walker Lane belt is a complex structural zone that is dominated by large right-lateral faults with northwest orientations, such as the Pahrump-Stewart Valley fault zone, the Furnace Creek fault zone, and the southern Death Valley fault zone. The study area lies within a region of moderately high to high heat flow that is interpreted to result from the complex tectonic history of the region, particularly contemporary and Neogene extensional tectonism, and to the presence of relatively young heat sources (Sass and others, 1994).

\section{Hydrogeologic Setting}

In order to support interpretation of regional and local hydrology, geochemistry, and groundwater flow paths, the hydrogeologic setting of the study area is considered at two scales. At the subregional scale, the hydrogeology is described for the southern Death Valley subregion, an area of approximately 4,600 square miles $\left(\mathrm{mi}^{2}\right)$ from the crest of the Spring Mountains to the southern end of Death Valley (D'Agnese and others, 1997; fig. 1). This scale of observation encompasses the geology along potential groundwater flow paths from regional upland recharge sites to the LAV and the Amargosa River. At the local scale, the stratigraphy and structure of the Tecopa basin is considered in order to support interpretation of geologic controls on groundwater movement to specific spring discharge sites.

\section{Southern Death Valley Subregion}

The study lies within a region designated as the southern Death Valley subregion of the Death Valley regional groundwater flow system (DVRFS), a major regional flow system that integrates groundwater flow over a large part of southern Nevada and eastern California (Belcher and Sweetkind, 2010). The subregion is defined as extending from the crest of the Spring Mountains southwestward approximately $60 \mathrm{mi}$ to the southern end of Death Valley (D'Agnese and others, 1997; Faunt, D'Agnese, and O'Brien, 2010). Previous geologic mapping of mountain ranges in the study area included the Spring Mountains (Page, Lundstrom, and others, 2005), the Nopah and Resting Spring Ranges (Burchfiel and others, 1982), the Kingston Range (Calzia and others, 2000), and the Dublin Hills (Chesterman, 1973). Regional hydrogeology was initially compiled by Faunt and others (1997) from 1:250,000-scale geologic maps in California and a 1:500,000-scale geologic map of Nevada. More recent geologic and geophysical investigations that included the southern Death Valley subregion were conducted as part of regional investigations of the DVRFS (Belcher and Sweetkind, 2010). Regional geology (Workman, Menges, Page, Taylor, and others, 2002), tectonic and structural features (Workman, Menges, Page, Ekren, and others, 2002), aeromagnetic data (Ponce and Blakely, 2001), gravity data (Ponce and others, 2001), and interpreted thickness of Cenozoic rocks (Blakely and Ponce, 2001) were compiled, a series of deep geologic cross sections (to $-33,000 \mathrm{ft}$ in altitude) of the region were constructed 
(Sweetkind, Dickerson, and others, 2001), and an interpretive map of structures with potential hydrologic significance was published (Potter and others, 2002). The Tecopa basin itself was mapped by Mason (1948), Hillhouse (1987), and Morrison (1999). The age and history of the Pleistocene Tecopa lake beds have been investigated by Caskey and Reheis (2014). Limited seismic, magnetic, and gravity data have been published for the Tecopa basin (Louie and others, 2001). The entire area is included in the regional-scale hydrogeologic framework of the DVRFS described by Faunt, Sweetkind, and Belcher (2010).

The southern Death Valley subregion includes from northeast to southwest, the high-standing block of the Spring Mountains, Pahrump Valley, the Nopah and Resting Spring Ranges, the Tecopa basin, and parts of the Greenwater Range and Black Mountains (fig. 1). To the south and southeast of the LAV, the subregion includes the Kingston Range and the Sperry Hills. The Amargosa Desert and the major spring discharge sites at Ash Meadows lie to the north of the LAV (fig. 2); these areas are included in the discussion because discharge from Ash Meadows springs may represent an intermediate source of water to the Tecopa basin.

The Spring Mountains in the northeastern part of the southern Death Valley subregion are bounded by major Cenozoic extensional and strike-slip faults, and the range is far less extended than surrounding areas (fig. 3; Sweetkind and others, 2001; Page, Lundstrom, and others, 2005). Within the range, a nearly complete stratigraphic sequence of Paleozoic carbonate rocks and underlying Neoproterozoic siliciclastic rocks are exposed; the sequence is partly disrupted by several Mesozoic-age thrust fault segments. The Paleozoic carbonaterock section in the Spring Mountains is inferred to be greater than 9,800 feet (ft) thick based on surface relations (Page, Lundstrom, and others, 2005). Average annual rainfall at the crest of the Spring Mountains is as much as 600 millimeters (Malmberg, 1967; Faunt, D'Agnese, and O'Brien, 2010), yet no significant streamflow exits the range except as flash floods during storm events. The ephemeral nature of streams within this range block that receives a relatively large amount of precipitation indicates that the carbonate bedrock has sufficient porosity and permeability to absorb and transmit most or all of this water as an aquifer (Hevesi and others, 2003; San Juan and others, 2010).

Pahrump Valley, immediately southwest of the Spring Mountains, is a topographically closed basin underlain by a structurally complex basin (Page, Lundstrom, and others, 2005). Gravity data have been used to calculate that the Cenozoic basin fill of the Pahrump Valley basin is mostly less than about 3,300 ft thick, except within two steep-sided basins on either side of the Stateline fault system, a large, segmented, northwest-striking strike-slip fault system that bisects the valley (fig. 3; Blakely and others, 1998; Scheirer and others, 2010). Surface geologic maps and drill-hole data show that the uppermost basin fill consists of unconsolidated Pliocene and younger coarse-grained alluvial materials that were deposited near the sides of the valley, and fine-grained playa, spring, and associated marsh or wetland deposits in the central part of the valley (Malmberg, 1967; Sweetkind

A

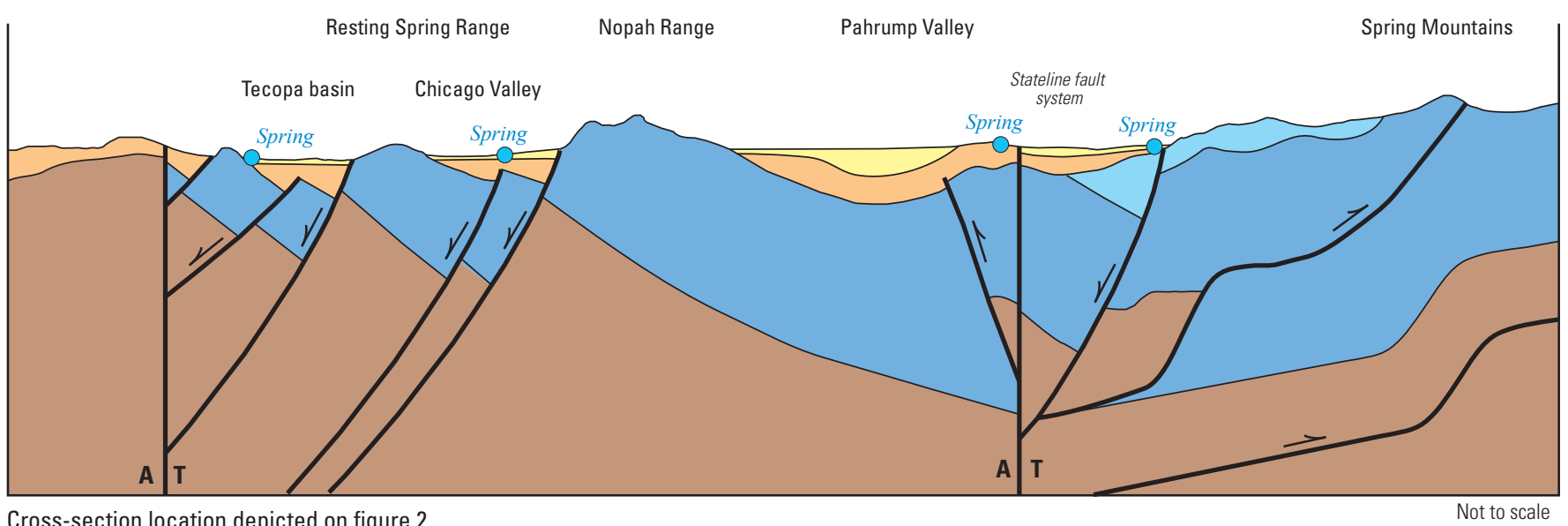

Cross-section location depicted on figure 2

EXPLANATION

Geologic units

Quaternary alluvium and valley fill

Cenozoic volcanic rocks, undivided

Paleozoic carbonate rocks, upper

Paleozoic carbonate rocks, lower

Proterozoic and Lower Cambrian siliciclastic rocks
Fault-Barbed arrows show relative sense of offset; $A$ and $T$ denote relative motion away from and toward the viewer, respectively 
and others, 2003; Page, Lundstrom, and others, 2005). The alluvial/basin-fill aquifer is locally confined under capping deposits of groundwater discharge-related tufa deposits in Pahrump Valley or fine-grained Tecopa lake bed deposits. Seismic data indicate that partly consolidated older Cenozoic rocks up to 6,600 to $9,800 \mathrm{ft}$ thick occupy the basins on either side of the Stateline fault system (Scheirer and others, 2010). Localization of small-volume springs along strands of the Stateline fault system (fig. 3) indicates that lateral movement of groundwater flow across them may be impeded (Malmberg, 1967). Paleozoic carbonate rocks have been inferred to underlie much of the basin fill (Malmberg, 1967; Sweetkind, Dickerson, and others, 2001), however, no deep wells penetrate to consolidated rock within the central part of the basin.

The Amargosa Desert basin is an intermontane structural basin that lies beneath the Amargosa Desert in southern Nevada and southeastern California (fig. 2). The basin comprises a complex assemblage of Tertiary and Quaternary sediments deposited in a trough to the northeast of the Funeral Mountains and to the west of the northwest end of the Spring Mountains (Oatfield and Czarnecki, 1989, 1991; Taylor and Sweetkind, 2014). Deeper parts of the basin are filled with consolidated and partly consolidated sedimentary rocks that range in age from Oligocene to late Miocene and are typically tuffaceous, clay-altered, and tilted and faulted (Sweetkind, Fridrich, and Taylor, 2001; Fridrich and Thompson, 2011). Older basin-fill deposits transition from coarse-grained gravel-dominated deposits in the northern part of the basin to fine-grained clay-dominated deposits at the southern end of the basin (Oatfield and Czarnecki, 1989, 1991; Taylor and Sweetkind, 2014). Pliocene deposits consist of widespread carbonate rocks and clays deposited in playas, marshlands, ponds, and floodplains (Hay and others, 1986). Unconsolidated Quaternary deposits include fine- to coarsegrained alluvial fan and stream channel deposits, spring discharge deposits, and eolian deposits, as both widespread sand sheets and more localized dunes (Denny and Drewes, 1965; Workman, Menges, Page, Taylor, and others, 2002). No deep boreholes penetrate to pre-Cenozoic bedrock in the center of the Amargosa Desert. The presence of carbonate bedrock underlying basin-fill sediments has been inferred on geologic cross sections across the basin (Sweetkind, Dickerson, and others, 2001; Fridrich and others, 2012), based on drillhole intercepts of Paleozoic rocks beneath Cenozoic rocks at the northeastern and southwestern edges of the Amargosa Desert (Carr and others, 1995; Wood, 2009; Fridrich and others, 2012), and on hydrochemical data from regional springs (Winograd and Thordarson, 1975; Steinkampf and Werrell, 2001).

Pahrump Valley and the Tecopa basin are separated by the uplifted range blocks of the Resting Spring Range, the Nopah Range, and by a part of the Kingston Range (figs. 2, 4). These ranges are separated by the intervening basins of Chicago and California Valleys. The Nopah and Resting Spring Ranges are east- and northeast-tilted fault blocks that are rotated by, and dip into, large-offset, down-to-the-west faults that bound the ranges (Burchfiel and others, 1983) (fig. 3). A nearly continuous 26,000-foot-thick stratigraphic section is exposed in the Nopah Range where Upper Paleozoic carbonate rocks are exposed at the northern end of the range and Neoproterozoic siliciclastic rocks are exposed at the southern end (Workman, Menges, Page, Taylor, and others, 2002; figs. 2, 4, cross-section B-B'). The east-tilted Resting Spring Range exposes several Mesozoic-age thrust sheets that juxtapose the Paleozoic carbonate rocks and the Neoproterozoic siliciclastic rock section. Between the Nopah and Resting Spring Range mountain blocks, Chicago Valley is an asymmetric graben with the master down-to-the-west fault near the eastern margin of the valley, at the base of the west flank of the Nopah Range (fig. 4, cross-section C-C'). The range-front fault on the west side of the Nopah Range has a west-side-down offset of approximately $6,500 \mathrm{ft}$ at the northern end of the Nopah Range (fig. 4; Burchfiel and others, 1983; Pavlis and others, 2014); fault offset increases southward to at least $19,700 \mathrm{ft}$ near the southern tip of the range (fig. 4, cross-section B-B'). Under the northernmost approximately $33,000 \mathrm{ft}$ of the range, fault offset is less than the thickness of the Paleozoic carbonate rocks, which are likely continuous across the western range front of the Nopah Range to downthrown, buried carbonate rocks under the northern part of Chicago Valley (figs. 3, 4). In contrast, the carbonate-rock section is completely faulted out at the southern end of the range, and Neoproterozoic siliciclastic rocks occur at the surface and in the subsurface (figs. 3, 4).

South and southwest of the LAV are several small ranges, including the Ibex Hills that are within the southern part of the Black Mountains (fig. 2). These small ranges are mainly composed of strongly faulted and fractured Neoproterozoic dominantly siliciclastic rocks of the Pahrump Group; no Paleozoic carbonate rocks are present in these range blocks.

\section{Tecopa Basin}

The general stratigraphic succession in the Tecopa basin includes, from oldest to youngest (1) a deep basement of crystalline rocks overlain by a 6,600-foot-thick Mesoproterozoic predominantly siliciclastic section, exposed at the southern end of the Nopah Range and in the Ibex Hills (fig. 5, unit 1); (2) a 600-foot-thick consolidated-rock section of Late Proterozoic and Lower Cambrian siliciclastic rocks, exposed on the western flanks of the Nopah and Resting Spring Ranges and in the Tecopa Hills (fig. 5, unit 2); (3) a 13,000-footthick Paleozoic succession of predominantly carbonate rocks, exposed in the Nopah and Resting Spring Ranges and in the Dublin Hills (fig. 5, unit 3); (4) partly consolidated Neogene sedimentary rocks, called the China Ranch beds, which are exposed in the Sperry Hills south of Tecopa and known to exist in the subsurface beneath the Tecopa basin (fig. 5, unit 4); (5) local accumulations of Neogene volcanic rocks (fig. 5, unit 5), exposed at the southern end of the Resting Spring Range and in the Dublin Hills, and locally intruded 


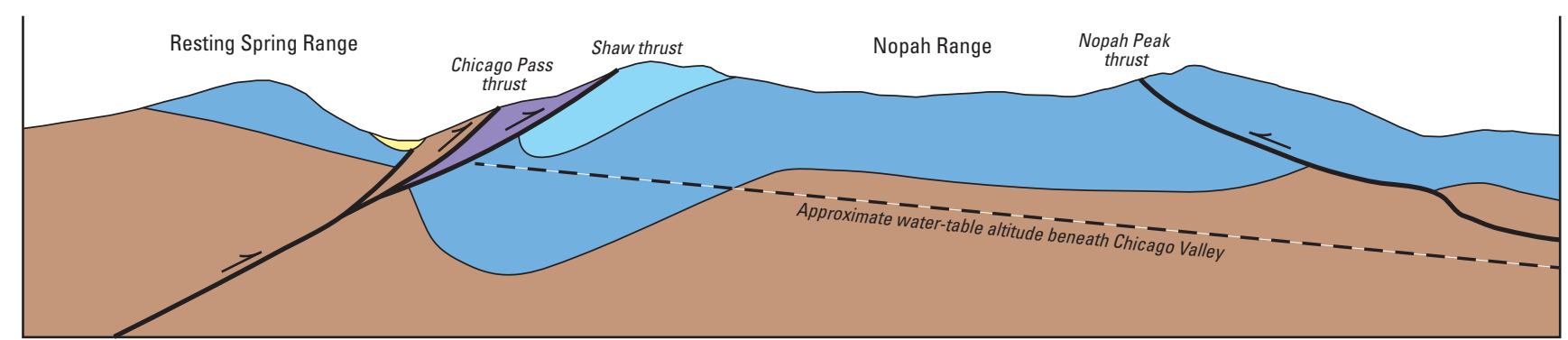

Cross-section location depicted on figure 2

Not to scale

C

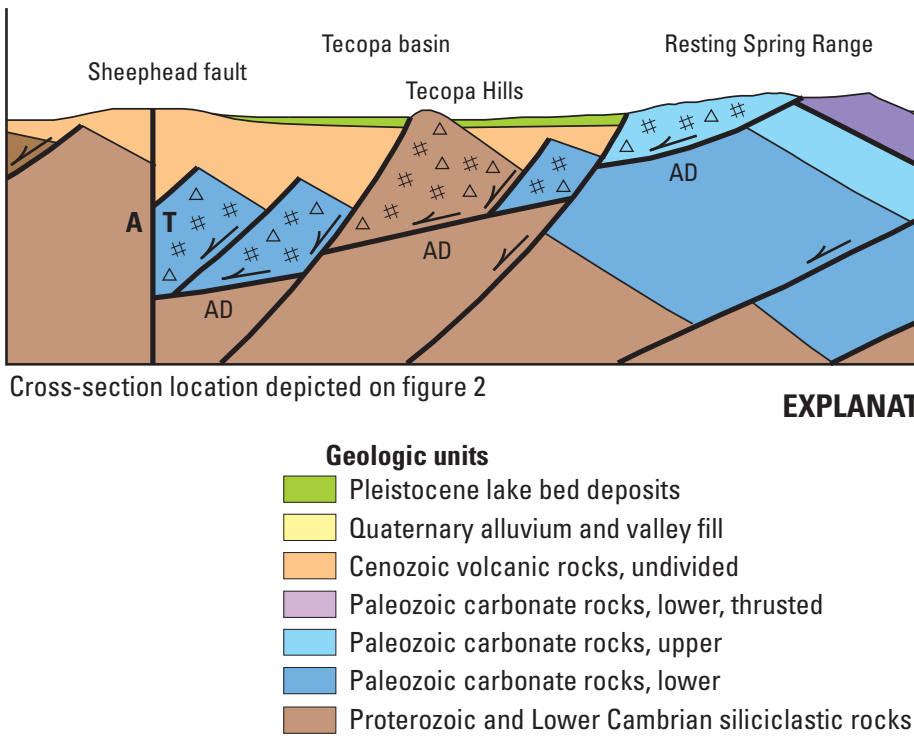

Figure 4. Diagrammatic geologic cross sections of the Nopah (B-B') and Resting Spring (C-C') Ranges, California.

by Neogene plutonic rocks (fig. 5, unit 6); (6) older and younger Quaternary alluvial and fluvial deposits that flank the ranges and occupy active channels, and younger fine-grained deposits that fill the valley bottoms (fig. 5 , units $7 \mathrm{a}, \mathrm{b}$, and c, respectively); and (7) Pleistocene Tecopa lake bed deposits and spring discharge deposits in the Tecopa basin and Chicago Valley (fig. 5, unit 8) ( Hillhouse, 1987; Sweetkind and others, 2001; Workman, Menges, Page, Taylor, and others, 2002).

Bedrock is covered throughout the Tecopa basin except for exposures of Late Proterozoic siliciclastic rocks in the Tecopa Hills (fig. 5). No deep wells penetrate bedrock within the Tecopa basin, and the lithology, continuity, and watertransmitting properties of concealed bedrock are highly uncertain. The maximum possible subsurface distribution of buried Paleozoic carbonate rock is confined to a subsurface region bounded to the east by the subsurface presence of older siliciclastic rocks in the southern half of the Nopah Range, to the south by the Sheephead fault - to the south of which only Neoproterozoic siliciclastic rocks are present, and to the west by the Dublin Hills, which represent the westernmost exposure of carbonate rock (fig. 5).
Locally large values of hydraulic conductivity for the carbonate rock result from the presence of fractures, solution channels, and enhanced permeability adjacent to faults (Winograd and Thordarson, 1975; Dettinger and others, 1995). Where hydraulically connected, these rocks provide a path for interbasin flow and support regional-scale groundwater flow systems (Harrill and others, 1988; Bedinger and others, 1989; Harrill and Prudic, 1998; Heilweil and Brooks, 2011). South and west of the Dublin Hills, bedrock exposures are mainly composed of strongly faulted and fractured siliciclastic rocks of the Mesoproterozoic Pahrump Group. The dominantly siliciclastic rocks of the Neoproterozoic sequence and the rocks of the underlying Pahrump Group are a regional confining unit (Winograd and Thordarson, 1975; Belcher and Sweetkind, 2010), although they may be transmissive where highly fractured and faulted. Mesoproterozoic Pahrump Group and Neoproterozoic siliciclastic rocks may transmit water where they are strongly faulted and fractured; extreme structural disruption within the Tecopa basin may allow the brecciated siliciclastic rocks to function as an aquifer. 


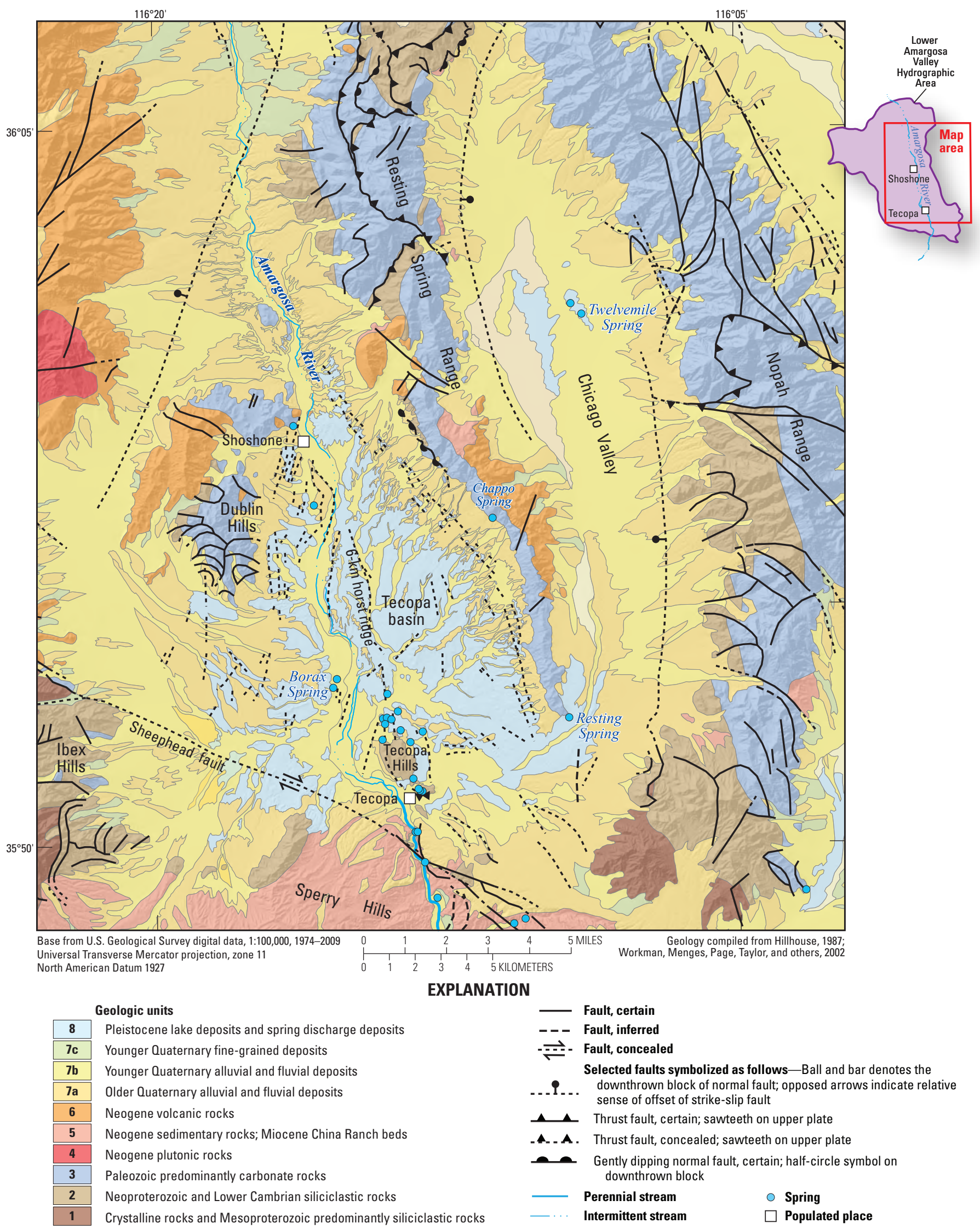

Figure 5. Geology of the Tecopa basin in the Lower Amargosa Valley study area, California. 
Miocene China Ranch beds overlie the Neoproterozoic siliciclastic rocks in the Sperry Hills immediately south of the Sheephead fault (figs. 4, 5). The China Ranch beds consist of semi-consolidated conglomerates, sandstones, and localized megabreccia (Topping, 1993; Prave and McMackin, 1999). The unit is synextensional, being deposited as the region was extending and the Tecopa structural basin was forming. In places, this tectonic activity is recorded by the presence of megabreccia in the sedimentary section-coarse conglomerate and breccia lenses that were the result of tectonic upliftdriven landslides that were deposited in the opening adjacent sedimentary basins (Topping, 1993; Prave and McMackin, 1999). The China Ranch beds are inferred to exist in the subsurface of the Tecopa basin, beneath the Tecopa lake beds and above bedrock. A west-east seismic profile across the basin displays an irregular set of seismic reflections below the horizontal reflectors of the Tecopa lake bed section and above the interpreted top of bedrock. The irregular reflections are interpreted to represent variably dipping and faulted Cenozoic rocks (Louie and others, 2001). Gravity and magnetotelluric (MT) data portray the top of bedrock as an irregular surface of variable elevation that probably represents the top of tilted, faulted bedrock blocks. Depressions between these blocks are likely filled with dipping, syntectonic Cenozoic sediments correlative to the China Ranch beds (Topping, 1993; Prave and McMackin, 1999). The Stauffer borehole (Rhodes, 1969), approximately $5 \mathrm{mi}$ northwest of the town of Tecopa, and the recent site of Borehole Spring, penetrated $350 \mathrm{ft}$ of finegrained Tecopa lake bed sediments before penetrating $3 \mathrm{ft}$ of what was interpreted as volcanic rock, but likely represents the top of the China Ranch beds section (Louie and others, 2001). The China Ranch beds make up an aquifer which is confined under capping deposits of the fine-grained Tecopa lake bed deposits.

The Tecopa basin contains a sequence of Recent to Miocene mudstones and thin-bedded volcanic ash deposited in Pleistocene Lake Tecopa, ringed by conglomerates on its margin (Hillhouse, 1987; Morrison, 1999) (fig. 5). Between approximately 5 million years ago and until approximately 200 thousand years ago, the Tecopa basin was the termination point for the Amargosa River and the site of Lake Tecopa. Throughout much of this time, depositional conditions oscillated between playa and shallow-lake conditions (Morrison, 1999; Caskey and Reheis, 2014). Lake Tecopa rose to its highest stage at 186 thousand years ago, after which the outlet in the Sperry Hills was breached or overtopped and the lake quickly drained. Between Death Valley Junction and Shoshone, the channel of the Amargosa River is incised into older, partly consolidated basin-fill deposits. Subsequent erosion has created extensive badlands in the Tecopa basin that expose approximately $240 \mathrm{ft}$ of the Tecopa lake bed deposits (Morrison, 1999).

The Tecopa lake beds are as thick as $560 \mathrm{ft}$ (Louie and others, 2001). These beds confine groundwater within the center of the basin (Larsen and others, 2001) and include soluble minerals that locally influence groundwater chemistry.
Mineralogy of the Tecopa lake beds varies throughout the basin and includes gaylussite, authigenic potassium feldspar, illite, sealesite, opal, quartz, calcite, halite, dolomite, siderite, aragonite, and gypsum (Starkey and Blackmon, 1979; Larsen, 2008).

The Tecopa lake beds are divided into two lithofacies: (1) lacustrine mudstone, claystone, and thin volcanic ash marker beds; and (2) shoreline facies conglomerate, fanglomerate and pebbly fluviatile deposits. Hillhouse (1987) mapped a chain of carbonate tufa deposits along the eastern margin of the basin as a third lake-related lithofacies, but subsequent mapping has shown these to be largely unrelated to lake processes (Morrison, 1999; Nelson and others, 2001). Seismic reflection data and one borehole that penetrates the full thickness of the lake bed section demonstrate the presence of an additional 300-ft-thick section of subhorizontal and undeformed Plio-Pleistocene lake bed sequence beneath the lowest beds exposed at the surface (Rhodes, 1969; Louie and others, 2001). The Amargosa River channel and all other tributary channels do not completely cut through the lake beds, which form a continuous blanket across the Tecopa basin. The altitude of exposed siliciclastic bedrock at the northern end of Amargosa Canyon creates a local base level, which limits the depth that the Amargosa River can incise into the 300-footthick lake bed sediments.

The Tecopa basin is bounded on the south by the Sheephead fault, which has about $12 \mathrm{mi}$ of right-lateral offset (fig. 5; Fridrich and Thompson, 2011); Neoproterozoic siliciclastic rock is uplifted to the south of the fault. Westdipping range-front faults along the west side of the Resting Spring Range bound the east and northeast side of the Tecopa basin. A series of north- and northeast-striking faults with Quaternary offset lie along the west side of the Tecopa basin (Morrison, 1999), with Neoproterozoic siliciclastic bedrock and overlying Cenozoic Greenwater volcanics uplifted to the west (fig. 5). Faulted and shattered siliciclastic rocks in the Tecopa Hills are the surface expression of a fault-bounded uplifted block that trends north-south beneath the Tecopa basin, named the "6-km horst ridge" (Morrison, 1999) (fig. 5).

Geologic mapping and geophysical data indicate that the main bounding fault beneath the Tecopa basin (1) dips westward and is down-to-the-west, dropping the carbonaterock section exposed in the Resting Spring Range into the basin; and (2) has a listric geometry (that is, dip lessens with depth) such that the fault is present under most of the Tecopa basin at geologically shallow depths, probably nowhere much deeper than approximately $13,000 \mathrm{ft}$. The steeply east-dipping Dublin Hills may be a large bedrock fault block that has been rotated into this west-dipping fault. The west side of the Resting Spring Range marks the transition from east-rotated range blocks to the highly extended terrane exposed in the Black Mountains to the west (Snow and Wernicke, 2000). The west-dipping fault that bounds the west side of the Tecopa basin is likely the eastern edge of the Amargosa detachment fault, a very large low-angle normal fault that is exposed in the west-central part of the Black Mountains (Wright and 
Troxel, 1984), approximately 16 mi northwest of the Tecopa basin. In the Black Mountains, consolidated rocks in the upper plate of this fault are structurally thinned and internally shattered fault slivers; similar highly deformed rocks may lie at depth beneath the Tecopa basin.

A series of younger, more steeply west-dipping faults occur on the east side of the Tecopa basin (fig. 4). These faults are locally expressed as a series of west-dipping hogbacks that expose moderately west-dipping fault planes and fault breccia that cut the bedrock exposures at the base of the Resting Spring Range (fig. 5; Gross and Louie, 1992). These faults cut the Tecopa lake bed deposits, and a series of carbonate tufa mounds are aligned along the fault trend (fig. 5; Morrison, 1999; Nelson and others, 2001). The tufa mounds are fault-controlled paleospring deposits along the west side of the Resting Spring Range and represent paleogroundwater discharge through the lake bed deposits. The Tecopa Hills and the 6-km horst ridge are bounded by relatively steep-dipping faults within the basin. Geophysical data from profiles across the Tecopa Hills indicate that these faults are relatively planar and extend to at least a few miles in depth (Brian Rodriguez, U.S. Geological Survey, written commun., June 2015).

\section{Hydrology}

In Winter and others (1998), Robert Hirsch (U.S. Geological Survey) writes that "[t]raditionally, management of water resources has focused on surface water or ground water as if they were separate entities. As development of land and water resources increases, it is apparent that the development of either of these resources affects the quantity and quality of the other." To manage the resources of the AWSR, the sources and quantities of the water of these linked systems must be understood.

Climatic conditions in the DVRFS region vary significantly and are primarily controlled by altitude. The southern part of the region, which includes Death Valley, the eastern Mojave Desert, and the LAV, is characterized by hot, dry summers and warm, dry winters (Benson and Darrow, 1981). Precipitation in the region is influenced by two distinct storm patterns, one occurring in the winter and the other in the summer. Winter precipitation (dominantly snow in the mountains and rain in the valleys) tends to be of low intensity and long duration, and covers great areas. In contrast, most summer rains, resulting from local convective thunderstorms, are of high intensity and short duration (Hales, 1972, 1974).

\section{Groundwater}

The LAV study area is in the southern part of the DVRFS, in the southern Death Valley subregion (fig. 1). Groundwater in the southern Death Valley subregion primarily is derived from recharge in the Spring Mountains and to a lesser extent from recharge in the Nopah, Kingston, and Greenwater Ranges (Faunt, D’Agnese, and O'Brien, 2010) (fig. 1). Most of the discharge in the subregion is from pumpage in Pahrump Valley (Faunt, D'Agnese, and O'Brien, 2010). However, previous interpretations of hydrologic data (Malmberg, 1967), geochemical data (Steinkampf and Werrell, 2001), and results from numerical modeling (Faunt, Blainey, and others, 2010) indicate that the springs and seeps of the Tecopa basin are regional discharge sites within the southern Death Valley subregion. Groundwater flow under Pahrump Valley has been inferred to exit the basin to the southwest (interbasin flow) on the basis of (1) the monotonic southwestward slope of the water table under Pahrump Valley toward the northern Nopah Range (Malmberg, 1967), (2) the absence of significant discharge from springs or playas in the southwestern part of the Pahrump Valley (Malmberg, 1967), and (3) the presence of presumably permeable Paleozoic carbonate rocks in the Nopah and Resting Spring Ranges to the west of Pahrump Valley (Malmberg, 1967; Harrill, 1986). However, little water-level data are available to define the regional potentiometric gradient to the west of the Nopah Range. Alternate groundwater flow paths to the Tecopa basin could result from the southward movement of water from the Amargosa Desert through basin-fill deposits along the course of the Amargosa River. However, previous water-budget calculations (Harrill and others, 1988) and numerical modeling results (Faunt, Blainey, and others, 2010) indicate that the magnitude of groundwater and surface flow from the northern part of the Amargosa River system into the southern part is far too small to explain the high discharge rates of Tecopa basin springs. Previously collected geochemical data indicate that Tecopa basin spring discharge is isotopically similar to that of Pahrump Valley springs and dissimilar to that of springs to the north at Ash Meadows (Steinkampf and Werrell, 2001).

Fractures and faults within the consolidated hydrogeologic units constitute the dominant pathways for regional groundwater flow (Faunt, 1997). The presence, orientation, and type of fault provide major controls on groundwater flow (Faunt, 1997, p. 24-31).

The overall flow system can be thought of as a set of relatively shallow localized flow systems that overlie and can be in some degree of hydraulic connection with a deeper regional flow system (Faunt, D'Agnese, and O'Brien, 2010). Within the entire Amargosa River basin, groundwater occurs within the alluvial/basin-fill deposits and the consolidatedrock aquifer (Walker and Eakin, 1963). Alluvial/basin-fill and regional consolidated-rock aquifer water-table and potentiometric-surface maps are shown on figure 6 . Because it was beyond the scope of this project to create new water-table and potentiometric-surface maps of these aquifer systems, existing maps were used. 


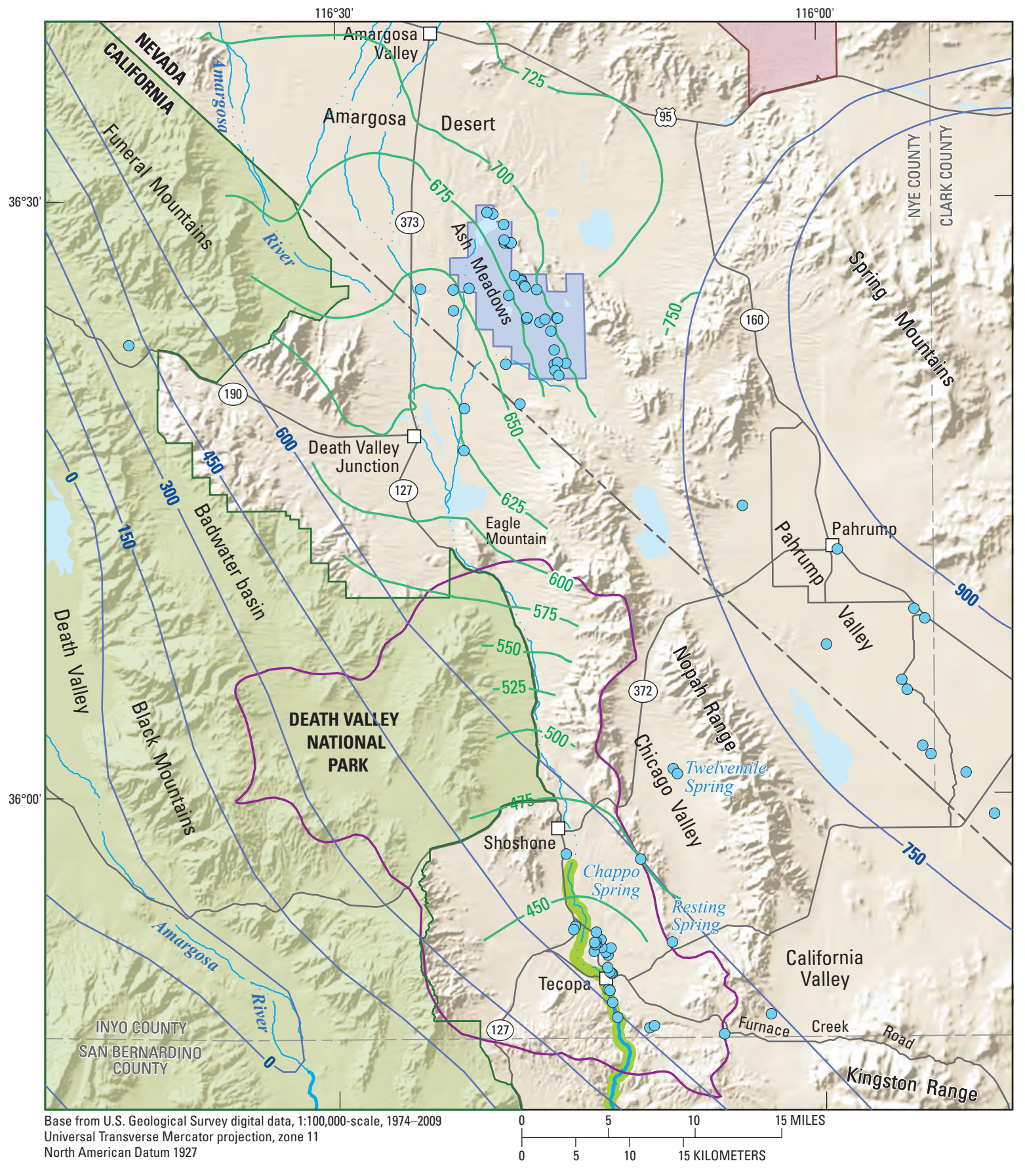

EXPLANATION

Death Valley National Park

Ash Meadows National Wildlife Refuge

Nevada National Security Site

Playa

Amargosa Wild and Scenic River

Lower Amargosa Valley Hydrographic Area
-450 - Water-level contour in shallow alluvium - Shows altitude at which water level would have stood in tightly cased wells, in meters above National Geodetic Vertical Datum of 1929. Contour interval 25 meters. Modified from Andy Zdon \& Associates, Inc., 2014

- 150 - Regional potentiometric surface contour-Shows altitude of potentiometric surface, in meters above National Geodetic Vertical Datum of 1929. Contour interval 150 meters. From Bedinger and Harrill, 2010

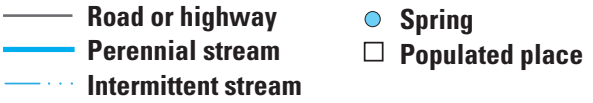

Figure 6. Alluvial/basin-fill aquifer water-level surface and the regional potentiometric surface in the carbonate- and volcanic-rock aquifer in the Lower Amargosa Valley and extra-basin contributing areas, California and Nevada. 
Groundwater in the alluvial/basin-fill aquifer system occurs largely in the basin fill of the valleys and the alluvial deposits of the Amargosa River channel as an unconfined aquifer. Groundwater generally moves from points of recharge at higher altitudes (such as the Nopah Range and the Black Mountains) to lower-altitude points of discharge such as the springs or Amargosa River in the Tecopa basin. Groundwater moves through these deposits, downgradient toward the lowest point in the Tecopa basin, the Amargosa River channel. Water also likely moves southward from the Amargosa Desert in the basin-fill deposits in the LAV. Figure 6 and plate 1 show the water-table surface map for the alluvial/basin-fill aquifer groundwater system, modified from Zdon and others (2015).

The regional potentiometric-surface map contours shown on figure 6 (Bedinger and Harrill, 2010) represent the deeper flow system in the volcanic- and carbonate-rock aquifer and do not necessarily follow or reflect topography like the watertable surface contours for the alluvial/basin-fill system. The contours were developed to represent flow on a regional scale and do not reflect the detailed, more localized flow through specific areas of the regional carbonate-rock aquifer. The contours indicate general flow directions from the regional recharge area of the Spring Mountains to the southwest toward Death Valley. It is important to note that the contours represent hydraulic potential and may not correspond to groundwater flow pathways, especially in relatively impermeable units. Actual flow volumes through the aquifer are governed by the hydraulic gradient and the hydraulic conductivity of the rocks. As an example, hydraulic-head gradients derived from the potentiometric-surface map depict water in the carbonate-rock aquifer moving from the Spring Mountains through Pahrump Valley and through the Nopah and Resting Spring Ranges to discharge in the Tecopa basin because the carbonate-rock aquifer is relatively transmissive (fig. 6, pl. 1). In contrast, the occurrence of significant groundwater flow from the Tecopa basin through the lower-transmissivity volcanic rocks of the Greenwater Range has not been definitively established, despite the presence of a favorable hydraulic-head gradient.

Groundwater movement in the regional flow system generally originates as recharge in highland areas and along mountain fronts and as underflow across the lateral boundaries of the DVRFS. Because of present-day arid conditions, recharge from precipitation is generally restricted to higher altitudes, and virtually no recharge of direct precipitation occurs in lowland valley areas. Regional groundwater discharges from springs or by evapotranspiration at locations in valley floors (Fenelon and others, 2010).

Within the Tecopa basin, the altitude of the regional potentiometric surface (Bedinger and Harrill, 2010) is usually higher than the water-table surface of the shallower alluvial/ basin-fill aquifer (fig. 6), indicating an upward gradient. This upward gradient is consistent with the occurrence of springs within the Tecopa basin where it drives deeper and warmer groundwater to the surface where the potential is higher than land surface. The relatively high temperatures of these springs, as well as their artesian (confined) conditions, indicates flow from a deeper system. The carbonate-rock aquifer appears to terminate directly south of Eagle Mountain north of the LAV and somewhere in the eastern part of the LAV (see "Hydrogeologic Setting" section).

Although there is undoubtedly some component of local recharge, most of the groundwater present in the LAV is likely sourced from the carbonate-rock aquifer. Discharge from springs and seeps in the area is greater than that of the local recharge to the basin, indicating an extra-basin source for the water. Although some have suggested that the carbonate-rock springs in the region are the result of Pleistocene recharge, the amount of water discharged from springs over time far exceeds the available storage in basin-fill aquifers (Belcher and others, 2009).

The actual degree of hydraulic connectivity between the alluvial/basin fill and carbonate-rock groundwater systems is largely unknown. However, because the carbonate-rock system appears to originate from depth (as indicated by elevated temperatures of spring water) and is under confined conditions (as indicated by artesian flow of the regional springs) the flow systems appear to have some degree of hydraulic separation. Water levels from a piezometer (ARHS-03; Andy Zdon, Andy Zdon \& Associates, Inc., written commun., 2015, 2016), near Twelvemile Spring show an approximate 60 -foot difference in water levels at the spring (assumed to be at land surface), indicating an upward hydraulic gradient from the carbonate-rock aquifer to the overlying alluvial/basin-fill aquifer.

\section{Surface Water}

In the DVRFS, perennial streamflow is sparse. Little or no perennial surface water is present in the lowlands and valley floors (Winograd and others, 2005). Most surface water in the region is either runoff or springflow discharge. Precipitation falling on the slopes of the mountains (such as the Black and Funeral Mountains) forms small, intermittent streams that quickly disappear into the fractured consolidatedrock and basin-fill deposits and infiltrate as groundwater recharge. In addition, several streams originate from snowmelt in the high altitudes of the Spring Mountains. Both types of streams have highly variable base flows and in dry years have no significant discharge. Springs maintain perennial flow for short distances in some of the drainages such as the Amargosa River. The most notable of these springs are in the Oasis Valley area, the Amargosa Narrows near Beatty, Nev., and in the area near Tecopa, Calif. (fig. 1). Seasonally, during storm events, the river can flow along its entire length. 


\section{Methods}

The methods used for the surface-water studies, chemical analyses, and conceptualization are described below.

\section{Surface Water}

Discharge measurements were made or compiled for selected springs and seeps in the study area. Although most of the surface-water features were monitored by the U.S. Geological Survey (USGS), a few springs, including Resting Spring, Thom Spring, and the Amargosa Canyon springs, were monitored by consultants to the Amargosa Conservancy between 2011 and 2014 (Andy Zdon \& Associates, Inc., 2014).

Discrete measurements of Shoshone Spring, Borehole Spring, Borax Spring, Tecopa Hot Spring, and Willow Creek were made with a Sontek FlowTracker or with a 3-inch portable Parshall flume using standard USGS methods (Buchanan and Somers, 1969, Kilpatrick and Schneider, 1983; U.S. Geological Survey Office of Surface Water, 2004). Each of the discharge measurements was field-rated as "poor" (uncertainty greater than 8 percent of actual discharge), "fair" (uncertainty greater than 5 percent and less than 8 percent of actual discharge), or "good" (uncertainty less than 5 percent of actual discharge) based on field estimates of standard error for each discharge measurement (Sauer and Meyer, 1992). Graphs of discharge measurements rated as poor were plotted with 10-percent error bars to indicate this level of uncertainty, as is the practice within the Rating Curve Toolbox software used to analyze the discharge measurements. In addition to the measured springs and seeps, groundwater pools and areas of diffuse discharge were identified and observed along the AWSR.

A synoptic seepage run was made for 32 sites along the Amargosa River from Shoshone Calif., to Dumont Dunes, in February 2014 to delineate losing and gaining reaches of the river and to assess the volume of water contributed to the AWSR by springs and seeps. For the synoptic seepage run, all discharge measurements were made with a Sontek FlowTracker or with a pygmy current meter using standard USGS methods (Buchanan and Somers, 1969; U.S. Geological Survey Office of Surface Water, 2004). Each of the discharge measurements was field-rated as poor based on field estimates of standard error for each discharge measurement (Sauer and Meyer, 1992). Reference points were installed at each site and tape downs (a measurement of the distance from the water surface to a local datum established by the hydrographer) were done before and after each measurement to monitor changes in the stage of the river.
During the seepage run, $\mathrm{pH}$ and temperature of the stream water were measured and samples were collected for alkalinity analysis. Water temperatures were measured using field thermistors that are checked annually against a NIST-traceable thermometer. The water temperatures were originally used as point samples to ensure the FlowTracker thermistors were functioning properly, but because the Amargosa River is not very wide or deep, it is assumed that the stream is well-mixed and that the measured temperatures are a reasonable surrogate for mean water temperature at each site. Specific conductance and $\mathrm{pH}$ were measured on grab samples with a Myron $\mathrm{L}$ Ultrameter II 6P multiprobe meter. The conductivity data were converted to specific conductance based on correction factors found in the USGS National Field Manual for the Collection of Water Quality Data (U.S. Geological Survey, variously dated). Alkalinity was determined by using the inflection point titration method on filtered samples. This titration method is described in the USGS National Field Manual for the Collection of Water Quality Data (U.S. Geological Survey, variously dated, chapter 6.6).

\section{Water Chemistry}

Data were compiled from several sources and used to create representative samples from the various sites that represent typical chemical conditions. Creating these representative samples involved sorting results at the same site from several dates according to various criteria and selecting samples with the greatest number of analytes or most complete geochemical analysis. Representative samples were checked against previous results (if available) to ensure that the water chemistry was consistent among dates sampled. If the water chemistry was reasonably consistent among sample dates, additional data from other samples collected at the site were included in the representative sample to fill data gaps. All sample results were rounded to two significant figures to provide more robust comparisons in data among sites. Isotopic data were rounded to three significant figures to provide higher resolution.

For groundwater and spring samples, charge balances were calculated to quality assure the validity of the representative chemical analyses; a charge balance of less than or equal to 10 percent was considered to represent a reasonable major-ion chemical analysis and the compilation of chemical analyses for that site acceptable. If total alkalinity was unavailable, bicarbonate values were used because carbonate values were mostly negligible in the charge balance equation (Drever, 1982, p. 39). However, if no alkalinity, bicarbonate, and carbonate values existed, a bicarbonate value was assumed to keep the charge balance within 10 percent. If samples did not charge balance with the existing alkalinity, the lack of charge balance was indicated. 
For ease of discussion, samples were classified into different groups based on geographic area, location, and physical characteristics. Commonly analyzed constituents (including physical properties, major ions, and selected trace elements and isotopes) that were present in the majority of samples were used in crossplots to delineate unique geochemical patterns among water groups. Crossplots help to identify unique patterns that may not be obvious using geochemical modeling alone, and they can provide insight into recharge sources and geochemical changes along a groundwater lake. Major-ion chemistry data were plotted on a Piper diagram to distinguish similar water types or hydrochemical facies among samples. Water type was determined by calculating the percentage contribution of each majorion to the total ionic composition of each sample. Milliequivalents per liter (meq/L) give each ion an equivalent weight, thereby allowing comparisons among the different ions.

The program PHREEQC (Parkhurst and Appelo, 2013) was used for geochemical modeling. Inverse modeling applies geochemical mass balance to observed chemical and isotopic compositions of natural waters to estimate masses of mineral and gas transfer in water-rock systems. The model is used to identify net geochemical reactions that account for observed changes in chemistry between a final water sample and one or more initial water samples ("initial" and "final" are descriptors of the location along the entire or partial regional flow path). Data required for inverse modeling include the chemical composition for all possible "initial" water samples and a "final" water sample that are assumed to be along a single (or joined) flow path. Saturation indices of selected minerals also were calculated using PHREEQC.

Geochemical models can be used to assess the chemical feasibility of a proposed flow path between two points. Valid model solutions account for the change in major-ion water chemistry between the "initial" and "final" waters along a flow path resulting from reactions with minerals and gases identified in the aquifer, proportional mixing of chemically different waters, and/or evaporation. Although inverse modeling of flow paths and quantitative mass transfers are discussed here, such modeling can only show whether chemical changes along a flow path are feasible: a valid model solution does not prove that such a flow path actually exists. Model input consisted of the chemical composition of solutions from analytical results, the set of gases and solid phases (minerals) involved in possible chemical reactions, and the set of elements and constraints required or available to chemically describe the solutions and phases. Previous studies have allowed for mixing of two waters in addition to geochemical reactions (Thomas and others, 2002), a technique employed as part of this study. The mineralogy used was based on the regional geology described in various reports (see "Water Chemistry" section); this mineralogy included anhydrite, amorphous silica, calcium montmorillonite, calcite, halite, gypsum, fluorite, illite, kaolinite, and the possible ion exchange between calcium and sodium.

PHREEQC allows for uncertainties in input solution data to calculate feasible reactions; allowing these uncertainties in models may allow for more models to be calculated, but introduces greater uncertainty into the interpretation of model output. In this study, tolerance of mass-balance uncertainty was raised from the default of 5 percent to 10 percent. Tolerance was raised to accommodate uncertainty resulting from combining chemical data from multiple samples to obtain the most representative chemical composition for each site and to determine the uncertainties in sampling and analytical techniques assumed in some sources of data. A closed system with little exchange of carbon dioxide gas between unsaturated zone carbon dioxide gas and the groundwater was assumed in modeling.

\section{Conceptualization}

The hydrogeologic conceptualization described in this report incorporates several different components. These components are based on the analysis and interpretation of the work of previous authors, use of existing potentiometric maps for the alluvial/basin-fill and carbonate/volcanic-rock aquifers, analysis of well driller reports, water chemistry, geochemistry and geochemical modeling, and geophysical surveys.

The basis of any groundwater investigation is waterlevel contour maps and water budgets. This study only used existing potentiometric-contour maps or water-level data, available in USGS or consultant reports. Similarly, water-budget components were obtained from previously published estimates and/or modeling (such as interbasin flow and recharge), or estimated as part of ongoing USGS work (pumping), river flow, and spring discharge.

\section{Surface-Water Measurements}

Regional spring discharge data were collected to obtain baseline information to assess impacts of future pumping or development on the springs and groundwater system. For the purposes of this report, springs and seeps were considered to be surface water, even though they are sourced in a groundwater system. Discrete discharge measurements were made by the USGS at selected regional springs in the study area, including Shoshone Spring, Borax Spring, and Tecopa Hot Springs (fig. 7). Other notable springs, Thom Spring and Resting Spring, were measured by consultants to the Amargosa Conservancy (Andy Zdon \& Associates, Inc., 2014). Streamgages were installed at Borehole Spring and on the spring-fed discharge of Willow Creek to record continuous stage (fig. 7). Two existing streamgages measure flow in the Amargosa River at Tecopa and above China Ranch Wash near Tecopa, Calif. (fig. 7). A synoptic seepage run measuring discharge at many points over a short period of time along the AWSR was completed during a period of low evapotranspiration in February 2014 to assess contributions to the river from spring discharge. All continuous and discrete data were quality-assured and entered into the USGS National Water Information System (NWIS) database. The data are publicly available at http://waterdata.usgs.gov/nv/nwis/rt. 


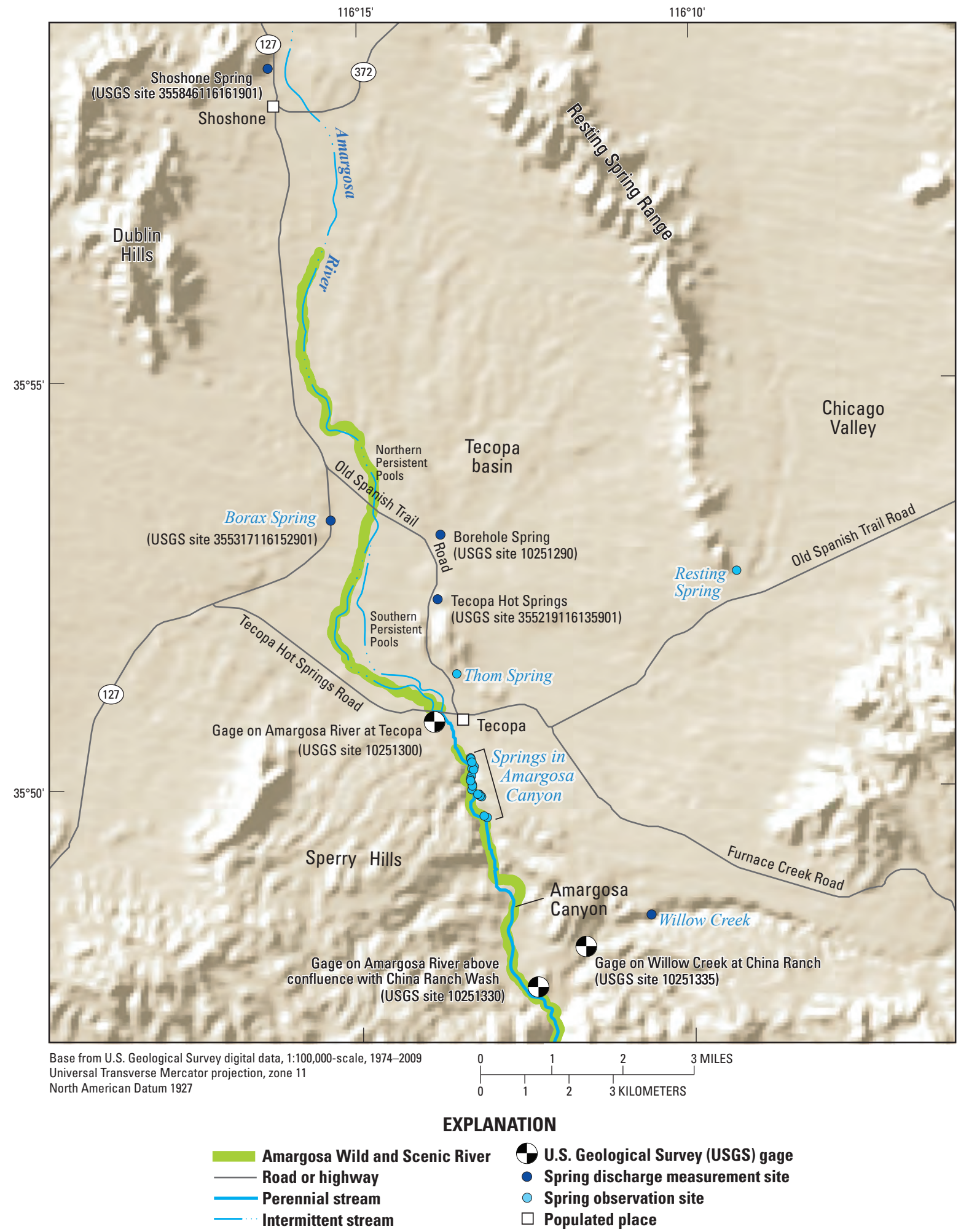

Figure 7. Surface-water and spring discharge measurement sites along the Amargosa Wild and Scenic River, California. 


\section{Discharge Measurements and Observations at Surface-Water and Discharge Sites}

One of the features of the LAV is the extensive and persistent nature of groundwater seeps and springs in the area. In cooperation with stakeholders and cooperators, several of these were selected for monitoring to assess contributions of flow into the Amargosa River as well as for establishing baseline data to assess future effects of climate change and/or anthropogenic activities. These spring and seep measurement sites (fig. 7) were

- Shoshone Spring (the primary water supply for the town of Shoshone, Calif.)

- Borax Spring

- Borehole Spring

- Tecopa Hot Springs

- Willow Creek (sourced at Willow Spring)

- Resting Spring

- Thom Spring

- Amargosa Canyon springs

In addition to the sites mentioned above, three other types of surface-water sites were assessed in the Tecopa basin:

- persistent pools (presumably fed by groundwater)

- diffuse discharge areas (salt-encrusted)

- the Amargosa River

\section{Shoshone Spring}

The Shoshone Spring complex is a series of springs and seeps that supply municipal and irrigation water to the town of Shoshone (fig. 7). Runoff from the spring complex contributes flow to a part of the Amargosa River. Total discharge of the spring complex is obtained through a combination of direct measurements of that part of the spring discharge that flows through the recreational pool and estimates of water diverted for municipal and irrigation use.

The concrete ditch below the swimming pool at Shoshone Spring (USGS site 355846116161901) was directly measured approximately every 6 weeks from May 2013 to February 2015. This ditch represents through-flow from the recreational pool and discharges into the Amargosa River (fig. 8). A summary of the 30 discharge measurements made at this site is presented in table 1 .

Measured discharge at the concrete ditch ranged from 0.05 to 0.52 cubic foot per second $\left(\mathrm{ft}^{3} / \mathrm{s}\right)$. The two measurements of $0.05 \mathrm{ft}^{3} / \mathrm{s}$ were made on a day when flow to the ditch was reduced in order for the pool to be cleaned. Excluding these measurements, measured discharge ranged from 0.17 to $0.52 \mathrm{ft}^{3} / \mathrm{s}$. The mean value of the measurements at the ditch was $0.33 \mathrm{ft}^{3} / \mathrm{s}$ and the median value of the measurements was $0.31 \mathrm{ft}^{3} / \mathrm{s}$. The site displays some seasonal variation, with greater discharge during the winter months and lower discharge during the summer months. Discharge is greater in the winter when evapotranspiration is lower (fig. 9). The temperature of the water discharging at the primary source at the spring boxes was about 33 degrees Celsius $\left({ }^{\circ} \mathrm{C}\right)$ (Andy Zdon \& Associates, 2014).

In addition to the pool outflow, the total discharge of the spring consists of the volume of water used for the town of Shoshone's water supply and the amount of water used to irrigate town landscaping. These components were estimated because of the difficulty of making direct measurements.

The town of Shoshone uses a reverse-osmosis system to treat springwater for municipal use (fig. 8). The Shoshone Development Corporation estimates that approximately 10,000 gallons per day is processed through the reverseosmosis system (Susan Sorrells, Shoshone Development Corporation, written commun., 2016), resulting in an annual water supply of approximately 3,652,500 gallons.

To estimate the amount of water used to irrigate the landscaping in and around Shoshone, satellite imagery was used to delineate the grass areas in town near the trailer park and the high school (fig. 10). This areal estimate was 9.3 acres. Applying an average net irrigation water requirement for grass in nearby Pahrump Valley of $5.2 \mathrm{ft}$ (Huntington and Allen, 2010) gives an approximate annual water use for irrigation of 49 acre-feet (acre-ft).

The total estimated annual discharge of the Shoshone Spring complex is the sum of (1) the average annual discharge from the pool outlet (24 acre-ft), (2) the estimated annual volume of water used to irrigate grass areas (approximately 50 acre-ft), and (3) the average annual volume of water used for the municipal water supply (approximately 11 acre-ft), resulting in an average springflow of about 300 acre-feet per year (acre-ft/yr) from 2013 to 2016. These amounts indicate that approximately 78 percent of the discharge from Shoshone Spring is non-consumptive and discharges to the Amargosa River. 


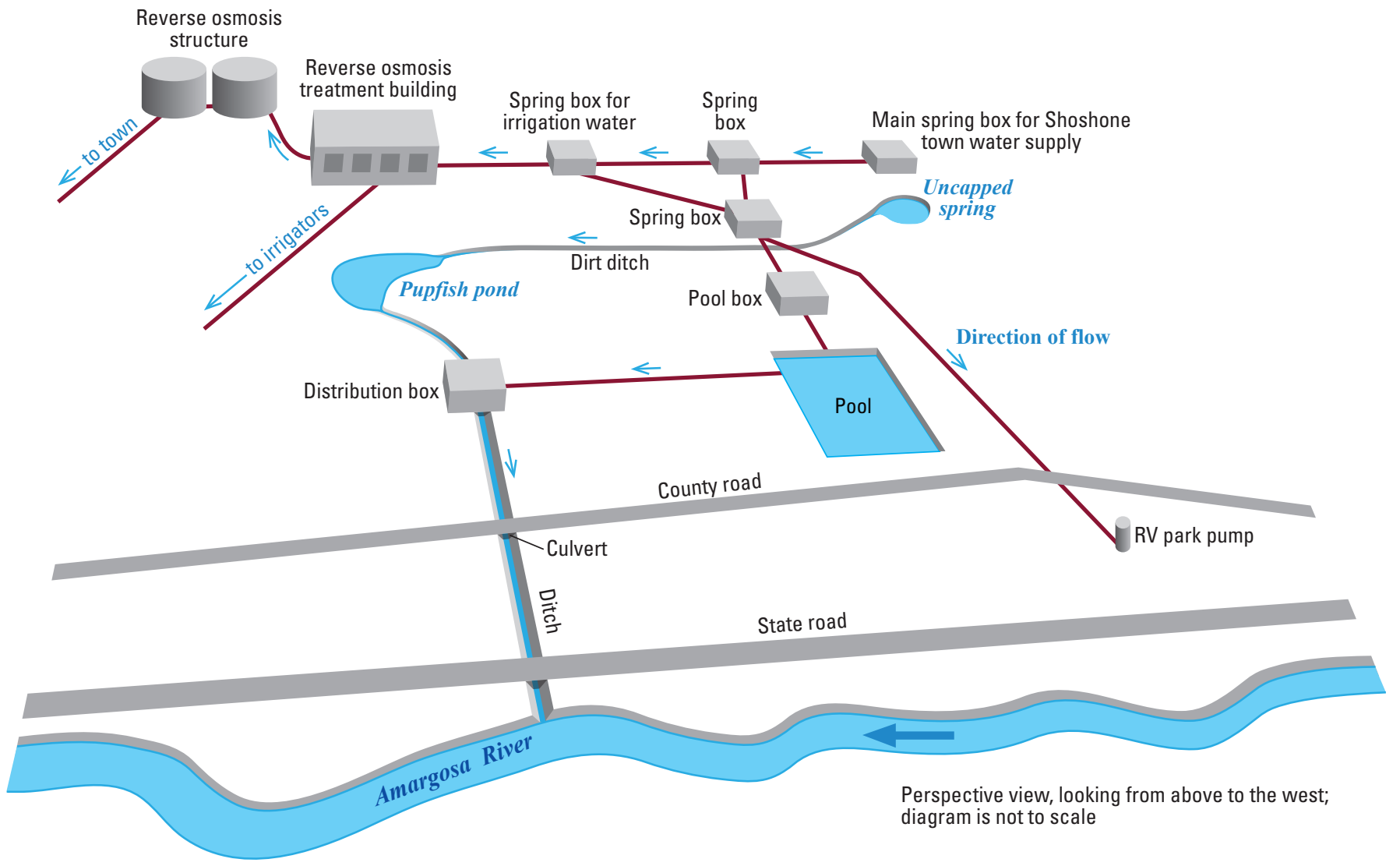

Figure 8. Water-supply system for Shoshone, California.

Table 1. Discrete discharge measurements at Shoshone Spring concrete ditch (U.S. Geological Survey site 355846116161901).

[Discharge rounded to two significant figures. Poor measurements are greater than 8 percent of actual discharge. Abbreviation: $\mathrm{mm} / \mathrm{dd} / \mathrm{yyyy}$, month/day/year]

\begin{tabular}{|c|c|c|c|c|c|c|c|}
\hline $\begin{array}{l}\text { Measurement } \\
\text { number }\end{array}$ & $\begin{array}{c}\text { Date } \\
\text { (mm/dd/yyyy) }\end{array}$ & $\begin{array}{c}\text { Discharge } \\
\text { (cubic feet per second) }\end{array}$ & Rating & $\begin{array}{c}\text { Measurement } \\
\text { number }\end{array}$ & $\begin{array}{c}\text { Date } \\
\text { (mm/dd/yyyy) }\end{array}$ & $\begin{array}{c}\text { Discharge } \\
\text { (cubic feet per second) }\end{array}$ & Rating \\
\hline 1 & $05 / 02 / 2013$ & 0.24 & Poor & 16 & $05 / 20 / 2014$ & 0.23 & Poor \\
\hline 2 & $05 / 02 / 2013$ & 0.21 & Poor & 17 & $05 / 20 / 2014$ & 0.20 & Poor \\
\hline 3 & $06 / 12 / 2013$ & 0.42 & Poor & 18 & $07 / 18 / 2014$ & 0.28 & Poor \\
\hline 4 & $06 / 12 / 2013$ & 0.34 & Poor & 19 & $07 / 18 / 2014$ & 0.35 & Poor \\
\hline 5 & $07 / 31 / 2013$ & 0.05 & Good & 20 & $08 / 28 / 2014$ & 0.19 & Poor \\
\hline 6 & $07 / 31 / 2013$ & 0.05 & Good & 21 & $08 / 28 / 2014$ & 0.24 & Poor \\
\hline 7 & 09/13/2013 & 0.31 & Poor & 22 & $08 / 28 / 2014$ & 0.17 & Poor \\
\hline 8 & 09/13/2013 & 0.31 & Poor & 23 & $10 / 27 / 2014$ & 0.30 & Poor \\
\hline 9 & $10 / 24 / 2013$ & 0.30 & Poor & 24 & $10 / 27 / 2014$ & 0.33 & Poor \\
\hline 10 & $10 / 24 / 2013$ & 0.27 & Poor & 25 & $11 / 20 / 2014$ & 0.46 & Poor \\
\hline 11 & $12 / 17 / 2013$ & 0.47 & Poor & 26 & $11 / 20 / 2014$ & 0.47 & Poor \\
\hline 12 & $01 / 28 / 2014$ & 0.42 & Poor & 27 & $01 / 08 / 2015$ & 0.43 & Poor \\
\hline 13 & $01 / 28 / 2014$ & 0.52 & Poor & 28 & $01 / 08 / 2015$ & 0.46 & Poor \\
\hline 14 & $02 / 27 / 2014$ & 0.40 & Poor & 29 & $02 / 19 / 2015$ & 0.27 & Poor \\
\hline 15 & 03/18/2014 & 0.37 & Poor & 30 & $02 / 19 / 2015$ & 0.26 & Poor \\
\hline
\end{tabular}




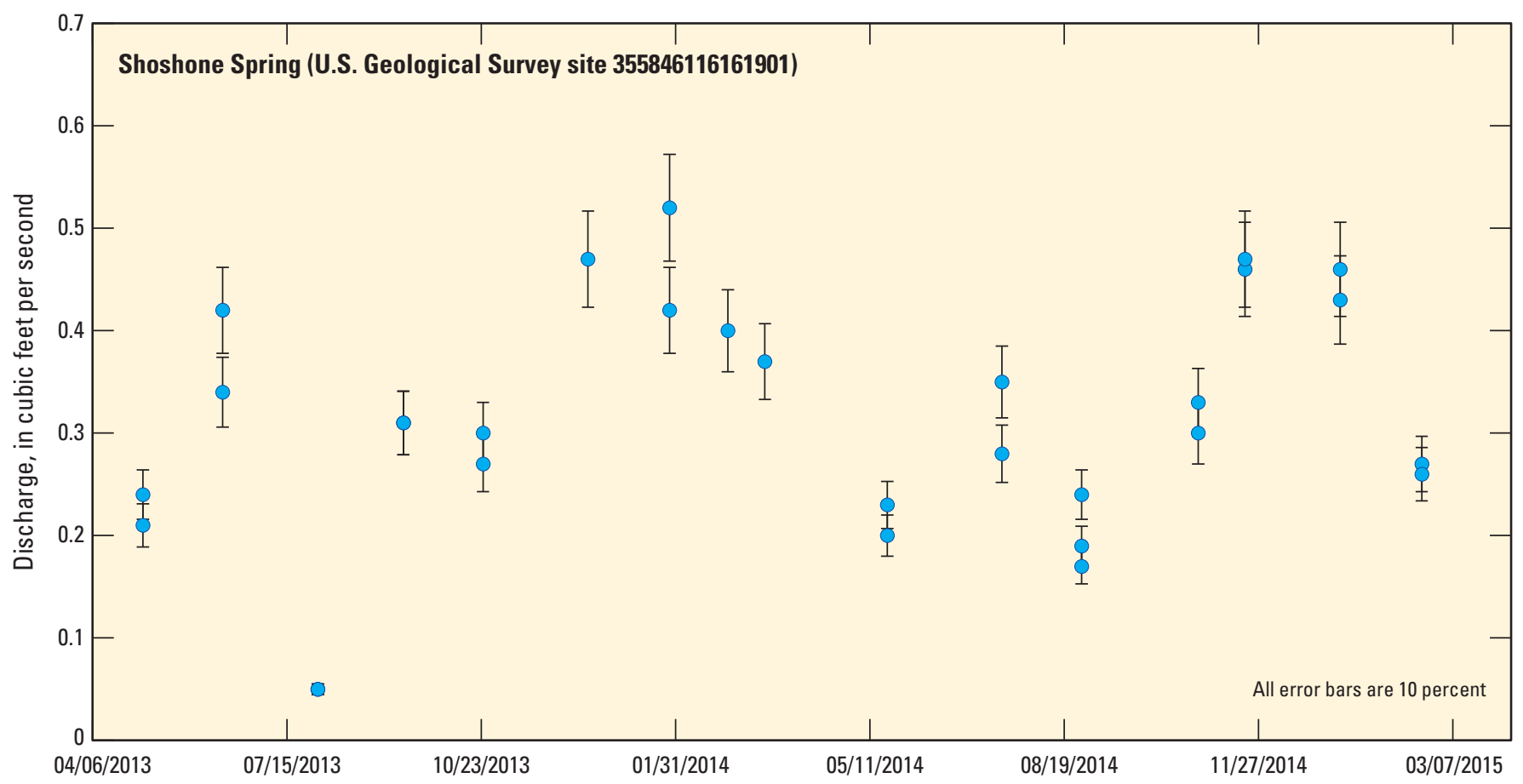

Figure 9. Discrete discharge measurements at Shoshone Spring concrete ditch, Lower Amargosa Valley, California.

\section{Borax Spring}

Borax Spring is located approximately 6 mi south of Shoshone, Calif., on the west side of the Tecopa basin at the old Amargosa Borax Works (fig. 7). At this site, spring discharge is captured in a pipe and flows into a small pond. Overland and subsurface waters leaving the spring and pond area flow toward the river channel to the east. Diffuse discharge is indicated by a salt crust between the west side of the basin and the river channel (pl. 1, moist bare soil evapotranspiration unit).

Borax Spring was directly measured approximately every 3 months (quarterly) from May 2013 to February 2015. Quarterly measurements were made to evaluate any seasonal trends in discharge from Borax Spring. Volumetric discharge measurements at Borax Spring were made with a volumecalibrated bucket and stopwatch (Rantz and others, 1982, p. 262-263). Each of the discharge measurements was fieldrated as poor (uncertainty greater than 8 percent of actual discharge) to good (uncertainty less than 5 percent of actual discharge) based on field estimates of standard error for each discharge measurement (Sauer and Meyer, 1992). A summary of the eight discharge measurements made at this site is presented in table 2 .

Measured discharge of Borax Spring ranged from 0.015 to $0.018 \mathrm{ft}^{3} / \mathrm{s}$ with a mean of $0.017 \mathrm{ft}^{3} / \mathrm{s}$ and a median of $0.0175 \mathrm{ft}^{3} / \mathrm{s}$. During the measurement on October 24, 2013, the pipe was leaking and the measured discharge was $0.016 \mathrm{ft}^{3} / \mathrm{s}$. The pipe was repaired on the visit on January 29, 2014, and the measured discharge was $0.017 \mathrm{ft}^{3} / \mathrm{s}$. On a subsequent visit to the site on May 15, 2014, discharge from the pipe was $0.018 \mathrm{ft}^{3} / \mathrm{s}$. Since May 15, 2014, the discharge of the spring has been consistently $0.018 \mathrm{ft}^{3} / \mathrm{s}$; it is likely that without the leaking pipe, the discharge would have been $0.018 \mathrm{ft}^{3} / \mathrm{s}$ for the entire period of record. Discharge measurements for Borax Spring are presented graphically on figure 11 and show that no seasonal trends are discernable in the data. The temperature of the spring is about $30^{\circ} \mathrm{C}$ (Andy Zdon \& Associates, 2014).

Table 2. Discrete discharge measurements at Borax Spring (U.S. Geological Survey site 355317116152901).

[Discharge rounded to three significant figures. Poor measurements are greater than 8 percent of actual discharge. Abbreviation: mm/dd/yyyy, month/day/ year]

\begin{tabular}{cccc}
\hline $\begin{array}{c}\text { Measurement } \\
\text { number }\end{array}$ & $\begin{array}{c}\text { Date } \\
\text { (mm/dd/yyyy) }\end{array}$ & $\begin{array}{c}\text { Discharge } \\
\text { (cubic feet per second) }\end{array}$ & Rating \\
\hline 1 & $05 / 02 / 2013$ & 0.015 & Good \\
2 & $07 / 31 / 2013$ & 0.015 & Good \\
3 & $10 / 24 / 2013$ & 0.016 & Poor \\
4 & $01 / 29 / 2014$ & 0.017 & Good \\
5 & $05 / 15 / 2014$ & 0.018 & Fair \\
6 & $08 / 20 / 2014$ & 0.018 & Good \\
7 & $11 / 20 / 2014$ & 0.018 & Poor \\
8 & $02 / 18 / 2015$ & 0.018 & Good \\
\hline
\end{tabular}



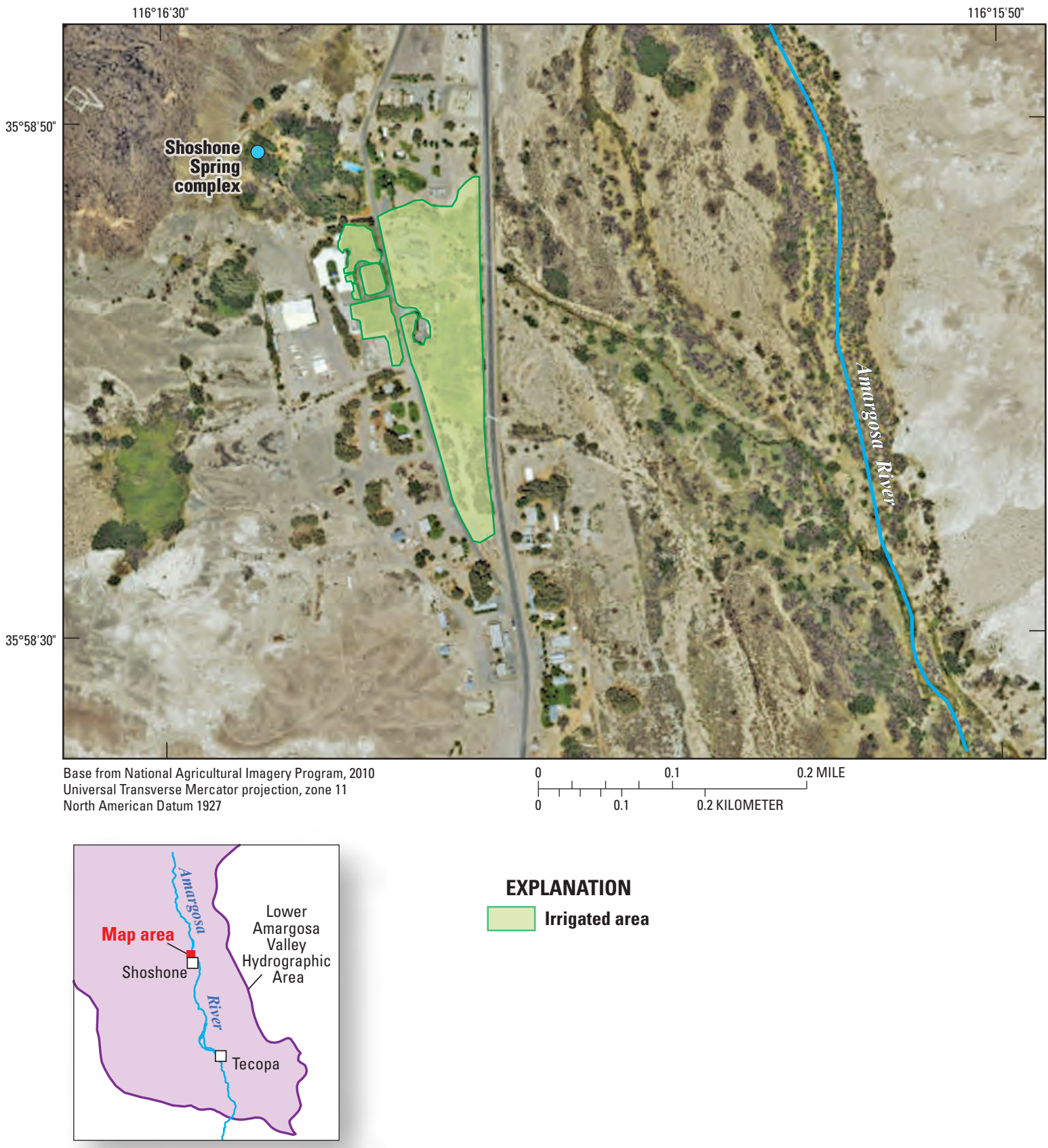

EXPLANATION

Irrigated area

Figure 10. Irrigated areas in Shoshone, California. 


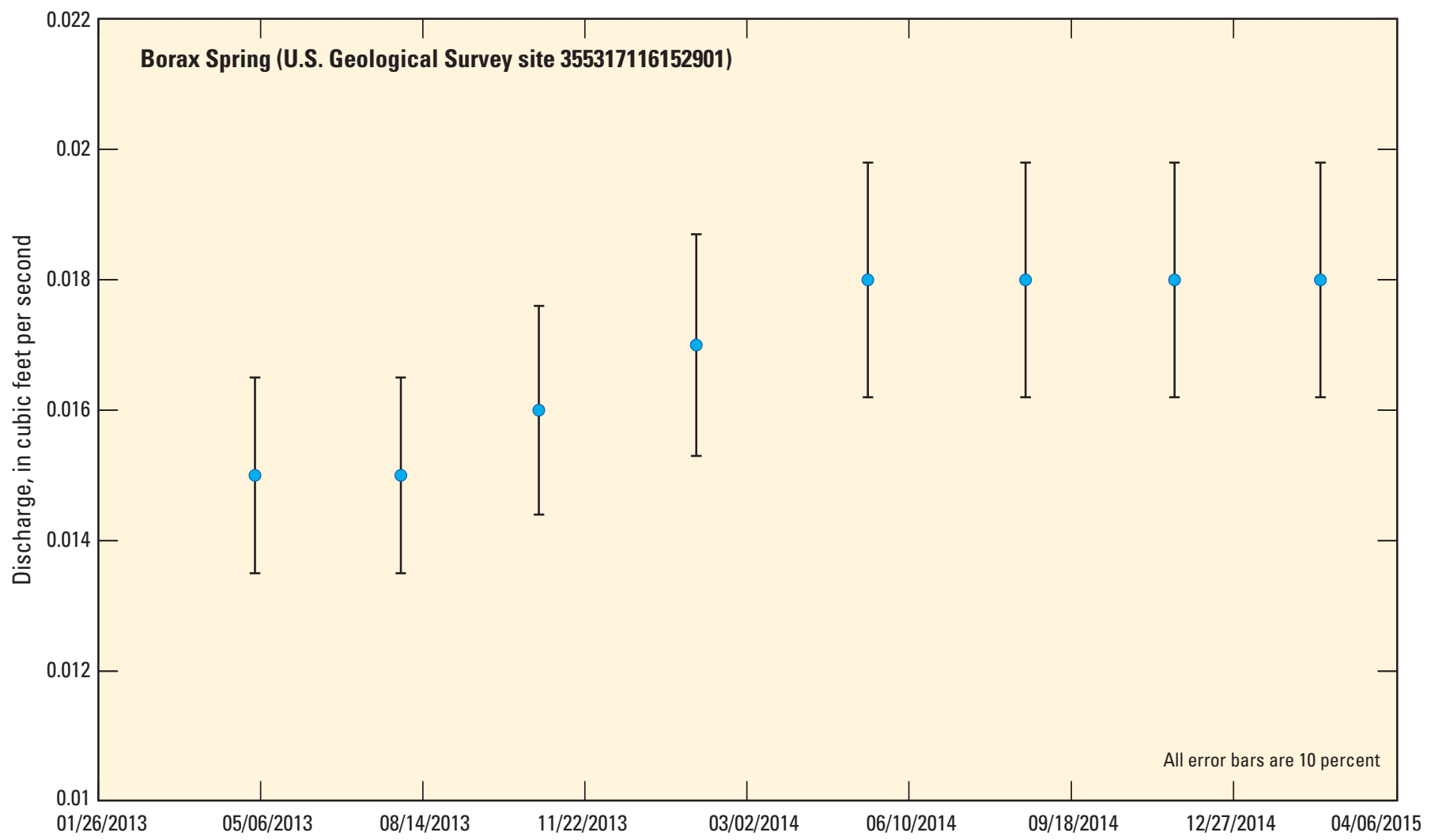

Figure 11. Discrete discharge measurements at Borax Spring, Lower Amargosa Valley, California.

\section{Borehole Spring}

Borehole Spring is a thermal spring located approximately $2.5 \mathrm{mi}$ north of Tecopa, Calif. (fig. 7). Borehole Spring was accidentally created by the Stauffer Chemical Company in March 1967 during exploratory drilling for sodium (Rhodes, 1969). The borehole penetrated into the Tecopa lake beds at a depth of approximately $350 \mathrm{ft}$ into the underlying China Ranch beds, containing thermal water under confining conditions.

Borehole Spring appears to contribute a significant amount of perennial flow to the Amargosa River. For the 4 water years of record prior to the creation of Borehole Spring (1962-1966), the USGS streamgage Amargosa River at Tecopa, Calif., measured an average streamflow of $0.63 \mathrm{ft}^{3} / \mathrm{s}$ during the non-monsoon season months of March, April, May, and June. In the 4 water years after Borehole Spring was formed (1968-1972), the gage measured an average streamflow of $1.0 \mathrm{ft}^{3} / \mathrm{s}$ for the same non-monsoon months. In addition to providing perennial flow to the Amargosa River, Borehole Spring is one of the few habitats for the endangered
Amargosa vole (Microtus californicus scirpensis) (Foley and others, 2014).

A continuous streamgage with a 15-minute recording interval was installed at the outlet channel for Borehole Spring on April 25, 2013. Direct measurements of discharge were made approximately every 6 weeks for the duration of the 2-year data collection phase of the project. All of the discharge measurements were field-rated as poor (greater than 8 percent of actual discharge) based on field estimates of standard error for each discharge measurement (Sauer and Meyer, 1992). A total of 30 discharge measurements were made between May 2013 and April 2015. Four measurements were considered to be of greater error than the others and were flagged as unused. A summary of the remaining 26 discharge measurements made at this site is presented in table 3 . Because the streamflow was difficult to measure accurately as the velocities are very low, repeat measurements were made on some visits.

Measured discharge (excluding "unused" measurements) ranged from 0.07 to $0.34 \mathrm{ft}^{3} / \mathrm{s}$ with a mean of $0.25 \mathrm{ft}^{3} / \mathrm{s}$ and a median of $0.27 \mathrm{ft}^{3} / \mathrm{s}$. Discharge measurements are presented graphically on figure 12 . 
Table 3. Discrete discharge measurements at Borehole Spring (U.S. Geological Survey site 10251290).

[Discharge rounded to two significant figures. Measurements 2, 8, 9, 12, and 30 were eliminated because of large errors. Poor measurements are greater than 8 percent of actual discharge. Abbreviation: $\mathrm{mm} / \mathrm{dd} / \mathrm{yyyy}$, month/day/ year]

\begin{tabular}{|c|c|c|c|}
\hline $\begin{array}{c}\text { Measurement } \\
\text { number }\end{array}$ & $\begin{array}{c}\text { Date } \\
\text { (mm/dd/yyyy) }\end{array}$ & $\begin{array}{c}\text { Discharge } \\
\text { (cubic feet per second) }\end{array}$ & Rating \\
\hline 1 & $05 / 03 / 2013$ & 0.07 & Poor \\
\hline 3 & $06 / 12 / 2013$ & 0.10 & Poor \\
\hline 4 & $07 / 31 / 2013$ & 0.16 & Poor \\
\hline 5 & 09/16/2013 & 0.21 & Poor \\
\hline 6 & $10 / 18 / 2013$ & 0.19 & Poor \\
\hline 7 & $12 / 17 / 2013$ & 0.27 & Poor \\
\hline 10 & $02 / 11 / 2014$ & 0.27 & Poor \\
\hline 11 & $02 / 11 / 2014$ & 0.27 & Poor \\
\hline 13 & $02 / 26 / 2014$ & 0.30 & Poor \\
\hline 14 & $03 / 11 / 2014$ & 0.34 & Poor \\
\hline 15 & $03 / 11 / 2014$ & 0.27 & Poor \\
\hline 16 & $03 / 11 / 2014$ & 0.31 & Poor \\
\hline 17 & $05 / 20 / 2014$ & 0.27 & Poor \\
\hline 18 & $05 / 21 / 2014$ & 0.27 & Poor \\
\hline 19 & $07 / 16 / 2014$ & 0.19 & Poor \\
\hline 20 & $07 / 16 / 2014$ & 0.19 & Poor \\
\hline 21 & 08/20/2014 & 0.31 & Poor \\
\hline 22 & $08 / 20 / 2014$ & 0.28 & Poor \\
\hline 23 & $10 / 15 / 2014$ & 0.27 & Fair \\
\hline 24 & $10 / 15 / 2014$ & 0.26 & Poor \\
\hline 25 & $11 / 20 / 2014$ & 0.32 & Poor \\
\hline 26 & $11 / 20 / 2014$ & 0.32 & Poor \\
\hline 27 & $01 / 07 / 2015$ & 0.25 & Poor \\
\hline 28 & $02 / 17 / 2015$ & 0.29 & Poor \\
\hline 29 & $02 / 17 / 2015$ & 0.34 & Poor \\
\hline
\end{tabular}

Discharge appeared to increase from April 25 to December 17, 2013, and then remained relatively steady at approximately $0.3 \mathrm{ft}^{3} / \mathrm{s}$. It is possible that this apparent increase is due to changes in the measurement method and measurement reach. The first three measurements at this site were made with the hydrographer standing directly in the water. From September 2013 to December 2013, measurements were made with the hydrographer standing on a wooden plank across the stream so flow would not be disturbed during the measurement. At some point between December 2013 and February 2014, the California Department of Transportation installed a rock ledge downstream from the gage, which improved measuring conditions by creating an area where a standard velocity profile exists and greater velocities can be measured. Prior to the installation of the rock ledge, discharge measurements were made in the 2-foot-deep main channel where mean velocities of 0.01 to 0.02 foot per second (ft/s) occurred with a non-standard velocity profile. Although the Sontek FlowTracker can be used within a velocity range of 0.003 to $13 \mathrm{ft} / \mathrm{s}$ (http://www.sontek.com/ productsdetail.php?FlowTracker-Handheld-ADV-1, accessed March 27, 2015), even a slight movement of the hydrographer while measuring at very low velocities can increase the error of a measurement. Measurements made on the rock ledge after installation had average depths of about $0.3 \mathrm{ft}$ and mean velocities of $0.3 \mathrm{ft} / \mathrm{s}$. Even though they are still rated as "poor," measurements on the rock ledge are likely more reliable than those made in the channel because the velocities are faster. Whether the apparent increase in discharge in 2013 represents an actual change in springflow or an artifact of changing measurement conditions was not possible to determine. Stream-flow records from June 2014 to April 2015 are more reliable, although they are still rated as poor due to periodic vandalism and difficult measurement conditions.

Borehole Spring exhibits daily fluctuations in discharge, which may be attributed to evapotranspiration (ET). From May to July 2013, the discharge increased, which is atypical behavior of springs in the Mojave Desert. Typically, discharge decreases during the hotter months from increased ET. The increase is probably a result of direct measurement error as described above, as well as channel construction or modifications by users of the spring.

From August to October 2013, discharge generally decreased from ET. From October 2013 to December 2013, discharge generally increased as ET decreased during the cooler months. A decrease occurs again from January 2014 to February 2014. In February 2014, the gage was vandalized, contributing to the poor record and the general decrease in discharge. Channel construction or modifications by users of the spring could also contribute to the poor record.

Discharge generally increased from March 2014 to April 2014, then generally decreased during the hottest part of the year through August 2014. A brief increase in discharge in May 2014 is most likely due to the installation of a standpipe near the road, which backed up more water. The standpipe was installed to mitigate damage to the adjacent Amargosa vole habitat. The standpipe installation was completed in June 2014. After August 2014, the discharge increased as ET decreased.

Computed daily discharge of Borehole Spring ranged from a minimum of $0.04 \mathrm{ft}^{3} / \mathrm{s}$ on May 1-2, 2013, to a maximum of $0.76 \mathrm{ft}^{3} / \mathrm{s}$ on Dec 23-24, 2013. The hydrograph of continuous daily values is presented on figure 12 . The temperature of the spring is approximately $47^{\circ} \mathrm{C}$ (Andy Zdon \& Associates, 2014). 

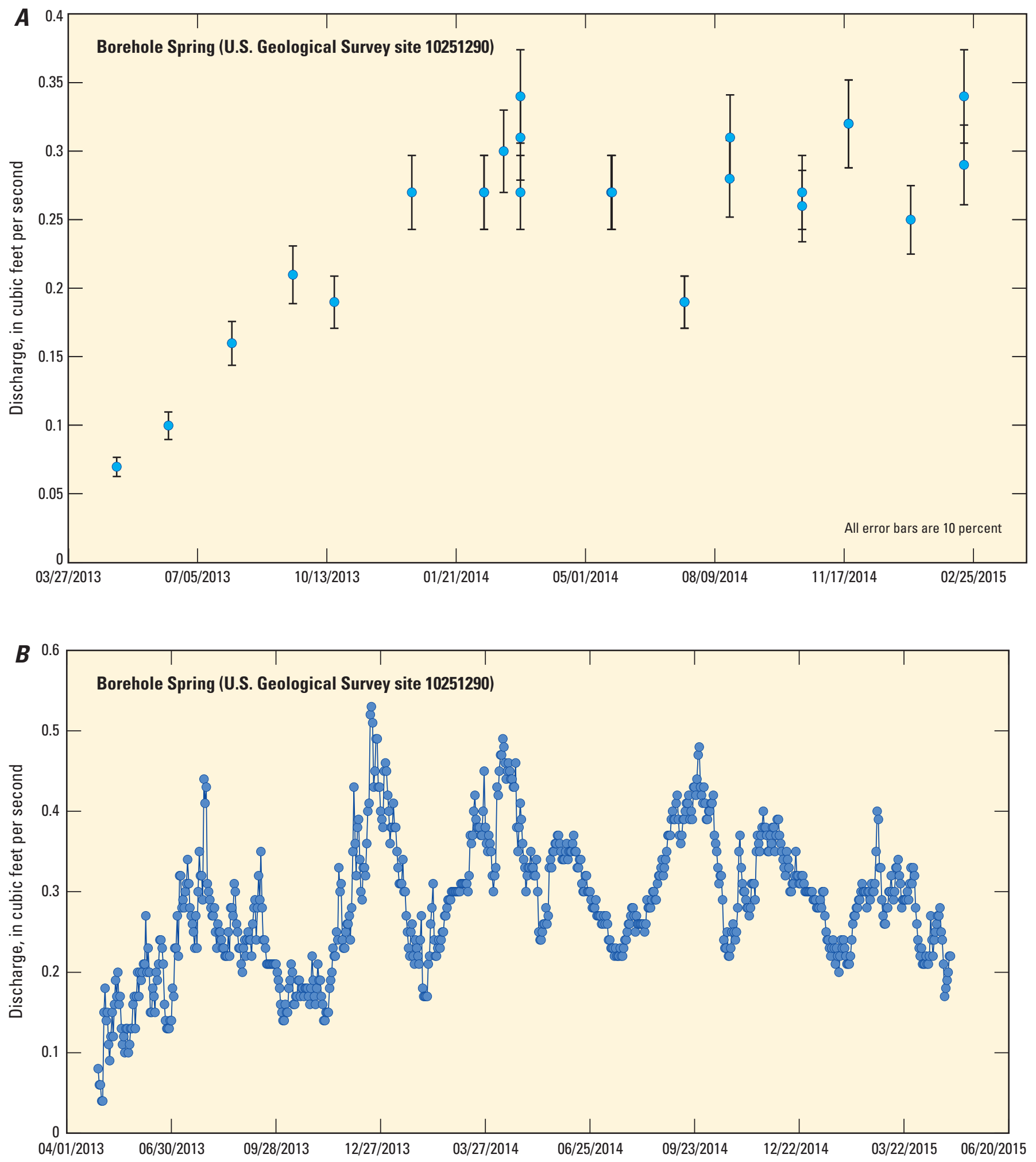

Figure 12. Discrete $(A)$ and daily $(B)$ discharge measurements at Borehole Spring, Lower Amargosa Valley, California. 


\section{Tecopa Hot Springs}

Tecopa Hot Springs is located in the Tecopa Hot Springs County Park (fig. 7) and is the original orifice used by the resort; most other resort facilities are supplied by artesian wells. The spring was the habitat for the now extinct Tecopa pupfish (Cyprinodon nevadensis calidae) (Miller and others, 1989). Tecopa Hot Springs was directly measured approximately every 3 months (quarterly) from April 2013 to February 2015 to assess any seasonal trends in discharge.

All of the discharge measurements were field-rated as poor (uncertainty greater than 8 percent of actual discharge) based on field estimates of standard error for each discharge measurement (Sauer and Meyer, 1992). A total of 17 discharge measurements were made. Four measurements were considered to be of greater error than the others and were flagged and unused. A summary of the remaining 13 discharge measurements made at this site is presented in table 4 .

Because the spring was difficult to measure accurately as the depths of the flow were shallow and the flow widths were narrow, two measurements were made on most visits.

There appears to be a slight seasonal trend of greater discharge in the winter and lower discharge in the summer, most likely due to ET, although this uncertainty may be due to limited record length. Discharge appeared to generally decline throughout the 2-year measurement period, although this apparent trend is influenced by the first measurement. It is unknown if the decline originates from normal minor changes from year-to-year at the site or if the decline is a permanent feature of the spring caused by aquifer drawdown or drought conditions.
Measured discharge of Tecopa Hot Springs (excluding unused measurements) ranged from 0.07 to $0.48 \mathrm{ft}^{3} / \mathrm{s}$ with a mean of $0.25 \mathrm{ft}^{3} / \mathrm{s}$ and a median of $0.24 \mathrm{ft}^{3} / \mathrm{s}$. The measurements are graphically presented on figure 13 . The temperature of the spring is approximately $40{ }^{\circ} \mathrm{C}$.

Table 4. Discrete discharge measurements at Tecopa Hot Springs (U.S. Geological Survey site 355219116135901).

[Discharge rounded to two significant figures. Measurements 3, 6, 12, and 13 were eliminated due to errors. Poor measurements are greater than 8 percent of actual discharge. Abbreviation: $\mathrm{mm} / \mathrm{dd} / \mathrm{yyyy}$, month/day/year]

\begin{tabular}{cccc}
\hline $\begin{array}{c}\text { Measurement } \\
\text { number }\end{array}$ & $\begin{array}{c}\text { Date } \\
\text { (mm/dd/yyyy) }\end{array}$ & $\begin{array}{c}\text { Discharge } \\
\text { (cubic feet per second) }\end{array}$ & Rating \\
\hline 1 & $04 / 25 / 2013$ & 0.48 & Poor \\
2 & $04 / 25 / 2013$ & 0.40 & Poor \\
4 & $07 / 31 / 2013$ & 0.07 & Poor \\
5 & $10 / 25 / 2013$ & 0.20 & Poor \\
7 & $10 / 25 / 2013$ & 0.16 & Poor \\
8 & $01 / 30 / 2014$ & 0.35 & Poor \\
9 & $01 / 30 / 2014$ & 0.37 & Poor \\
10 & $05 / 20 / 2014$ & 0.24 & Poor \\
11 & $05 / 20 / 2014$ & 0.21 & Poor \\
14 & $11 / 20 / 2014$ & 0.25 & Poor \\
15 & $11 / 20 / 2014$ & 0.30 & Poor \\
16 & $02 / 18 / 2015$ & 0.12 & Poor \\
17 & $02 / 18 / 2015$ & 0.16 & Poor \\
\hline
\end{tabular}

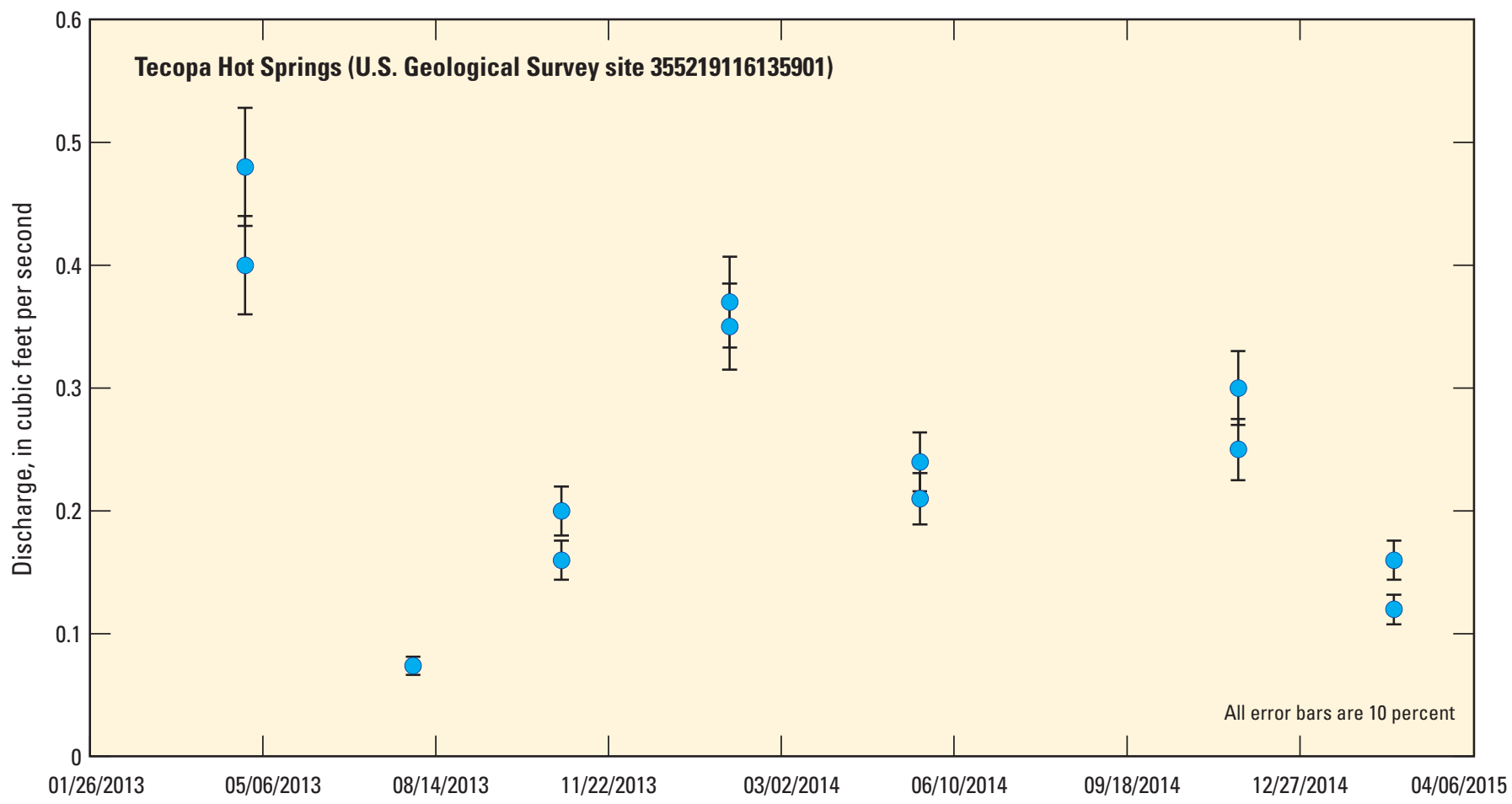

Figure 13. Discrete discharge measurements at Tecopa Hot Springs, Lower Amargosa Valley, California. 


\section{Willow Creek}

Willow Creek is a spring-fed stream that represents discharge from Willow Spring. The creek was measured at China Ranch, Calif. (fig. 7). A continuous streamgage with a 15-minute recording interval was installed on Willow Creek on February 20, 2013. Direct measurements of discharge were made approximately every 6 weeks from February 2013 to February 2015. A total of 38 discharge measurements were made between February 20, 2013, and March 12, 2015. Four measurements were considered to be of greater error than the others and were marked unused. Because the creek was difficult to measure accurately as the depths were shallow and the widths were narrow, two measurements were made on most visits. A summary of the remaining 34 discharge measurements made at this site is presented in table 5 .

Measured discharge (excluding unused measurements) ranged from 0.018 to $0.363 \mathrm{ft}^{3} / \mathrm{s}$ with a mean of $0.178 \mathrm{ft}^{3} / \mathrm{s}$ and a median of $0.116 \mathrm{ft}^{3} / \mathrm{s}$. Discharge measurements are presented graphically on figure 14 .

Willow Creek shows a strong seasonal trend of greater discharge in the winter and less in the summer, which can be partially attributed to increased ET in the summer. This site is also downstream from a pond and a french drain used to collect water for irrigation at the China Ranch Date Farm (Brian Brown, China Ranch Date Farm, oral commun., 2012), so it is likely that the low discharge in the summer months also reflects the effects of increased diversions for irrigation during warmer months in addition to ET.

The streamflow record at Willow Creek was ultimately rated as "poor" (95 percent of daily values are greater than 15 percent from the true value) due to variable gage-height control conditions. A "control" is a human-made or natural obstruction in the channel such as a rock riffle that backs up water and therefore controls the height of water at the gage. When the gage in Willow Creek was originally installed, it was located one culvert-width upstream of a culvert with a large tree growing on the upstream side. The tree was removed by the landowner, forming a steep gradient in the channel, subsequently changing the channel rating. A control was constructed out of rocks in an attempt to stabilize the channel at the gage, but the stream began eroding into its bed downstream from the rocks. The constant downcutting resulted in a slowly changing control for the entire period of record at the site.

Computed daily discharge ranged from a minimum of $0.02 \mathrm{ft}^{3} / \mathrm{s}$ on many days to a maximum instantaneous discharge of $0.956 \mathrm{ft}^{3} / \mathrm{s}$ on February 28, 2014. A hydrograph of continuous daily values is presented on figure 14 .

The continuous data show similar trends as the discharge measurements, with more discharge in the winter months and less in the summer due to ET and irrigation water use. Slight increases in discharge over the course of a few days during the warmer months are most likely due to irrigation by the date farm releasing water into Willow Creek.
Table 5. Discrete discharge measurements at Willow Creek (U.S. Geological Survey site 10251335).

[Discharge rounded to two significant figures. Measurements 18, 30, 34, and 35 had large errors and were not used. Poor measurements are greater than 8 percent of actual discharge. Abbreviation: mm/dd/yyyy, month/day/year]

\begin{tabular}{|c|c|c|c|}
\hline $\begin{array}{c}\text { Measurement } \\
\text { number }\end{array}$ & $\begin{array}{c}\text { Date } \\
\text { (mm/dd/yyyy) }\end{array}$ & $\begin{array}{c}\text { Discharge } \\
\text { (cubic feet per second) }\end{array}$ & Rating \\
\hline 1 & $02 / 20 / 2013$ & 0.36 & Poor \\
\hline 2 & $02 / 20 / 2013$ & 0.35 & Poor \\
\hline 3 & $02 / 22 / 2013$ & 0.31 & Poor \\
\hline 4 & $03 / 25 / 2013$ & 0.29 & Poor \\
\hline 5 & $03 / 25 / 2013$ & 0.31 & Poor \\
\hline 6 & $05 / 01 / 2013$ & 0.16 & Poor \\
\hline 7 & 05/01/2013 & 0.19 & Poor \\
\hline 8 & $05 / 20 / 2013$ & 0.11 & Poor \\
\hline 9 & $05 / 20 / 2013$ & 0.11 & Poor \\
\hline 10 & $05 / 23 / 2013$ & 0.12 & Poor \\
\hline 11 & $05 / 23 / 2013$ & 0.11 & Poor \\
\hline 12 & $06 / 10 / 2013$ & 0.09 & Poor \\
\hline 13 & $06 / 10 / 2013$ & 0.09 & Poor \\
\hline 14 & $07 / 30 / 2013$ & 0.02 & Poor \\
\hline 15 & $09 / 13 / 2013$ & 0.06 & Poor \\
\hline 16 & $09 / 13 / 2013$ & 0.05 & Poor \\
\hline 17 & $10 / 18 / 2013$ & 0.08 & Poor \\
\hline 19 & $01 / 30 / 2014$ & 0.32 & Poor \\
\hline 20 & $01 / 30 / 2014$ & 0.32 & Fair \\
\hline 21 & $01 / 30 / 2014$ & 0.35 & Fair \\
\hline 22 & $01 / 30 / 2014$ & 0.33 & Fair \\
\hline 23 & $03 / 20 / 2014$ & 0.36 & Poor \\
\hline 24 & $05 / 16 / 2014$ & 0.12 & Fair \\
\hline 25 & $05 / 16 / 2014$ & 0.12 & Fair \\
\hline 26 & $07 / 17 / 2014$ & 0.07 & Good \\
\hline 27 & $07 / 17 / 2014$ & 0.07 & Good \\
\hline 28 & $08 / 27 / 2014$ & 0.07 & Fair \\
\hline 29 & $08 / 27 / 2014$ & 0.08 & Fair \\
\hline 31 & $10 / 20 / 2014$ & 0.08 & Good \\
\hline 32 & $11 / 19 / 2014$ & 0.08 & Fair \\
\hline 33 & $01 / 08 / 2015$ & 0.09 & Poor \\
\hline 36 & $02 / 18 / 2015$ & 0.19 & Poor \\
\hline 37 & $03 / 12 / 2015$ & 0.31 & Poor \\
\hline 38 & $03 / 12 / 2015$ & 0.32 & Poor \\
\hline
\end{tabular}



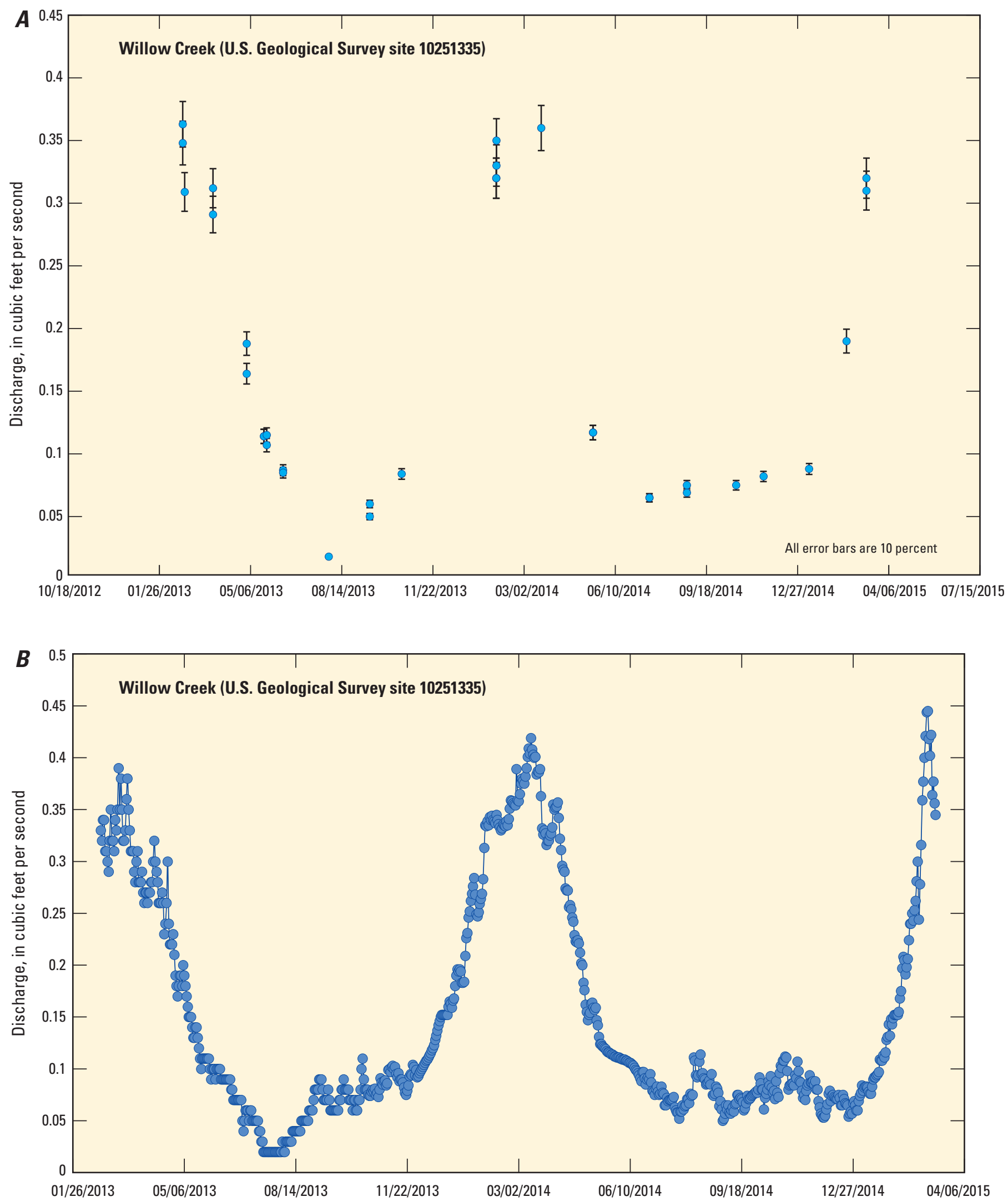

Figure 14. Discrete $(A)$ and daily $(B)$ discharge measurements at Willow Creek, Lower Amargosa Valley, California. 


\section{Resting Spring}

Resting Spring is a developed spring located on private property within the Resting Springs Ranch at the southern end of the Resting Spring Range (fig. 7). A discharge of $0.33 \mathrm{ft}^{3} / \mathrm{s}$ was measured during a site visit on January 23, 2011 (Andy Zdon \& Associates, 2014). Winograd and Thordarson $\left(1975\right.$, p. C43) also reported a flow of $0.33 \mathrm{ft}^{3} / \mathrm{s}$. These identical measurements, made decades apart, suggest that flow is likely stable at Resting Spring and connected to the regional carbonate-rock aquifer. The temperature of the spring is approximately $27^{\circ} \mathrm{C}$ (Andy Zdon \& Associates, 2014).

\section{Thom Spring}

Thom Spring is located on the southern end of the Tecopa Hills (fig. 7). Other smaller springs and seeps exist along the east side of the Tecopa Hills as well, as indicated by a band of salt crust (seeps) and vegetated areas (springs and seeps) (fig. 15). The water discharging from Thom Spring is about $28{ }^{\circ} \mathrm{C}$ and the flow is approximately 0.007 to $0.011 \mathrm{ft}^{3} / \mathrm{s}$ (Andy Zdon \& Associates, Inc., 2014).

\section{Amargosa Canyon Springs}

Along the east side of Amargosa Canyon, springs and seeps discharge along the contact between the China Ranch beds and Neoproterozoic siliciclastic rocks (Andy Zdon \& Associates, Inc., 2014). This series of relatively cool springs (most less than $25^{\circ} \mathrm{C}$ and ranging between 15 and $27^{\circ} \mathrm{C}$; Andy Zdon \& Associates, 2014) discharge along the bottom and wall of the east side of Amargosa Canyon for an approximately 1.3-mile reach of the Amargosa River (fig. 7). The northernmost discharge point in the canyon is a swampy area with flowing streams just downstream from the Tecopa gage on private land along the river. South of this discharge area, additional springs occur along the former Tonopah and Tidewater railroad bed. Flow of these springs ranges from less than 0.011 to greater than $0.067 \mathrm{ft}^{3} / \mathrm{s}$ (Andy Zdon \& Associates, Inc., 2014). Total flow from all the springs in Amargosa Canyon is unknown, but a synoptic seepage measurement was able to provide an estimate (see "Synoptic Seepage Run on the Amargosa Wild and Scenic River" section).

\section{Persistent Pools}

Along two reaches of the AWSR there are areas of persistent pools that appear to be fed by groundwater. Although it is possible that the pools are fed by Amargosa River water entering the river channel aquifer and then re-emerging, there are seeps and springs adjacent to both pools to the west and the east. The proximity of the seeps and springs indicates that spring discharge, infiltrating into the shallow subsurface and flowing toward the river channel, is likely the source of the pools. The northern set of pools are located between Shoshone, Calif., and Old Spanish Trail Road, and the southern set of pools are located between the Tecopa Hills and the gage at Tecopa (fig. 7). Both areas are marked by persistent vegetation even during hot seasonal periods and appear to flow during cooler months. Figure 16 shows a photograph of the southern groundwater-fed pools north of the Tecopa gage. Plate 1 shows the locations of the northern and southern persistent pools.

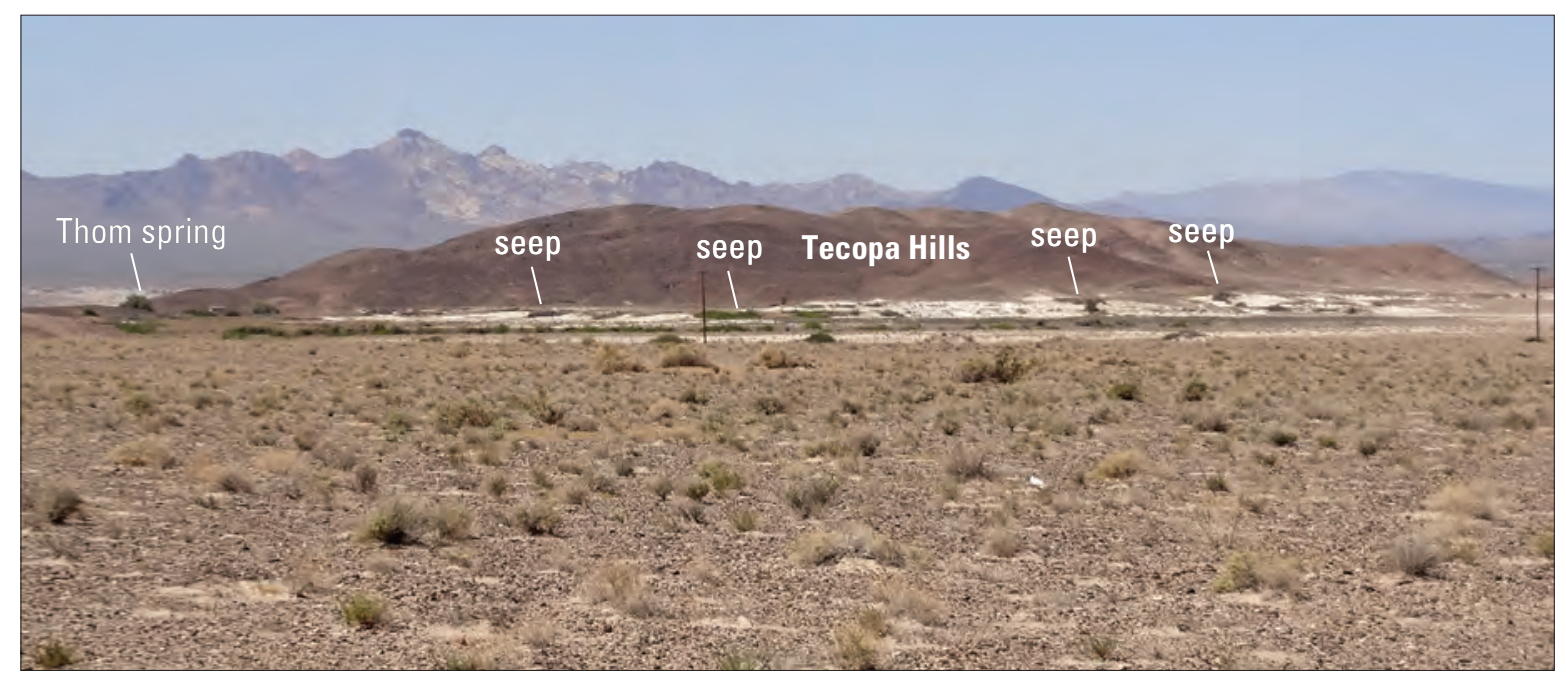

Figure 15. Southeast side of the Tecopa Hills in Lower Amargosa Valley, California, and the locations of seeps and springs, as indicated by salt crusts and perennial vegetation. Photograph taken by Donald S. Sweetkind, U.S. Geological Survey, April 3, 2015. 
The northern set of pools exist in an area of the river channel adjacent to bluffs of the Tecopa lake beds (fig. 7). The water in these pools is likely from the seeps and springs on the west side of the Tecopa basin flowing in the subsurface toward the incised channel of the Amargosa River. This is inferred from the groundwater altitudes in this site as well as the persistent vegetation in the vicinity of the river. The southern pools exist in an area of dissected headlands of the Amargosa Canyon, just upstream of the Tecopa streamgage (fig. 7).

The pools vary in size and flow into one another, eventually coalescing into a flowing reach of the river just upstream of the streamgage at Tecopa.

\section{Salt-Encrusted Areas}

Two areas of salt crust are present along the AWSR. These salt-encrusted soils are thought to be an indication of upward diffuse discharge through the Tecopa lake beds and are indicated by the evapotranspiration areas depicted on plate 1 . The northern area is located on the west side of the river from just south of the town of Shoshone to the Tecopa Hot Springs Road (fig. 7), whereas the southern area extends from the hot springs resort area to the town of Tecopa. It is inferred that diffuse groundwater evaporates leaving behind the salt crust/ evaporites. Figure 17 shows an example of the salt-encrusted areas to the west of the Amargosa River.

\section{Amargosa River}

Two long-term streamgages have been in continuous operation for several years at two sites on the main stem of the Amargosa River: Amargosa River at Tecopa (USGS site 10251300), and Amargosa River above China Ranch Wash near Tecopa, Calif. (USGS site 10251330). During periods of base flow, the reach between the Tecopa gage and the China Ranch gage gains water due to perennial spring inflows between the gages. However, these measurements include overland runoff during flood events that reflect greater flow than that from the springs alone (base flow).

The Amargosa River at Tecopa, Calif., streamgage (USGS site 10251300; fig. 7) was first installed in October 1961 and was operated as a continuous gage until August 1983. Infrequent discharge measurements were made at the site from October 1991 to September 1995 and again in 1998. The gage was re-established as a continuous streamgage in January 1999 and remains a continuous streamgage at present (2018). The maximum discharge recorded at the gage was $10,600 \mathrm{ft}^{3} / \mathrm{s}$ on August 19, 1983, during a flood event. The minimum discharge is no flow on some days in some years. Annual mean flows for the site are presented in table 6.

The streamgage at Amargosa River above China Ranch Wash near Tecopa, Calif. (USGS site 10251330; fig. 7), was installed in June 2006 and has operated as a continuous gage through the present (2018). The maximum discharge recorded at the site was 2,200 $\mathrm{ft}^{3} / \mathrm{s}$ on December 22, 2010. The minimum daily discharge was $0.25 \mathrm{ft}^{3} / \mathrm{s}$ on August 6, 2007. Annual mean flows for years of complete data are presented in table 7.

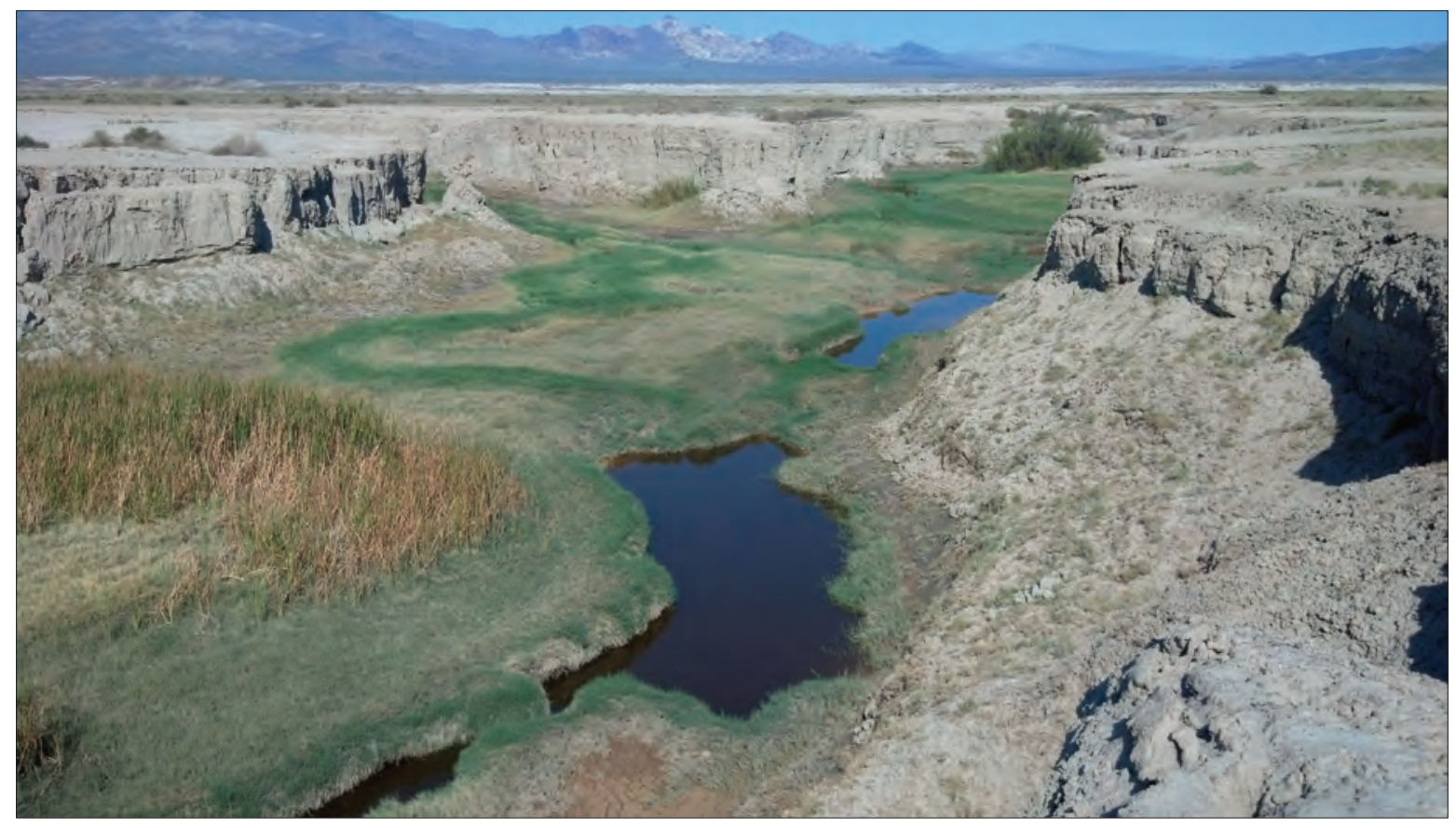

Figure 16. Persistent pools to the north of the Amargosa River at Tecopa, California streamgage in Lower Amargosa Valley. View looking upstream along the Amagosa River. Photograph taken by Wayne R. Belcher, U.S. Geological Survey, October 25, 2013. 


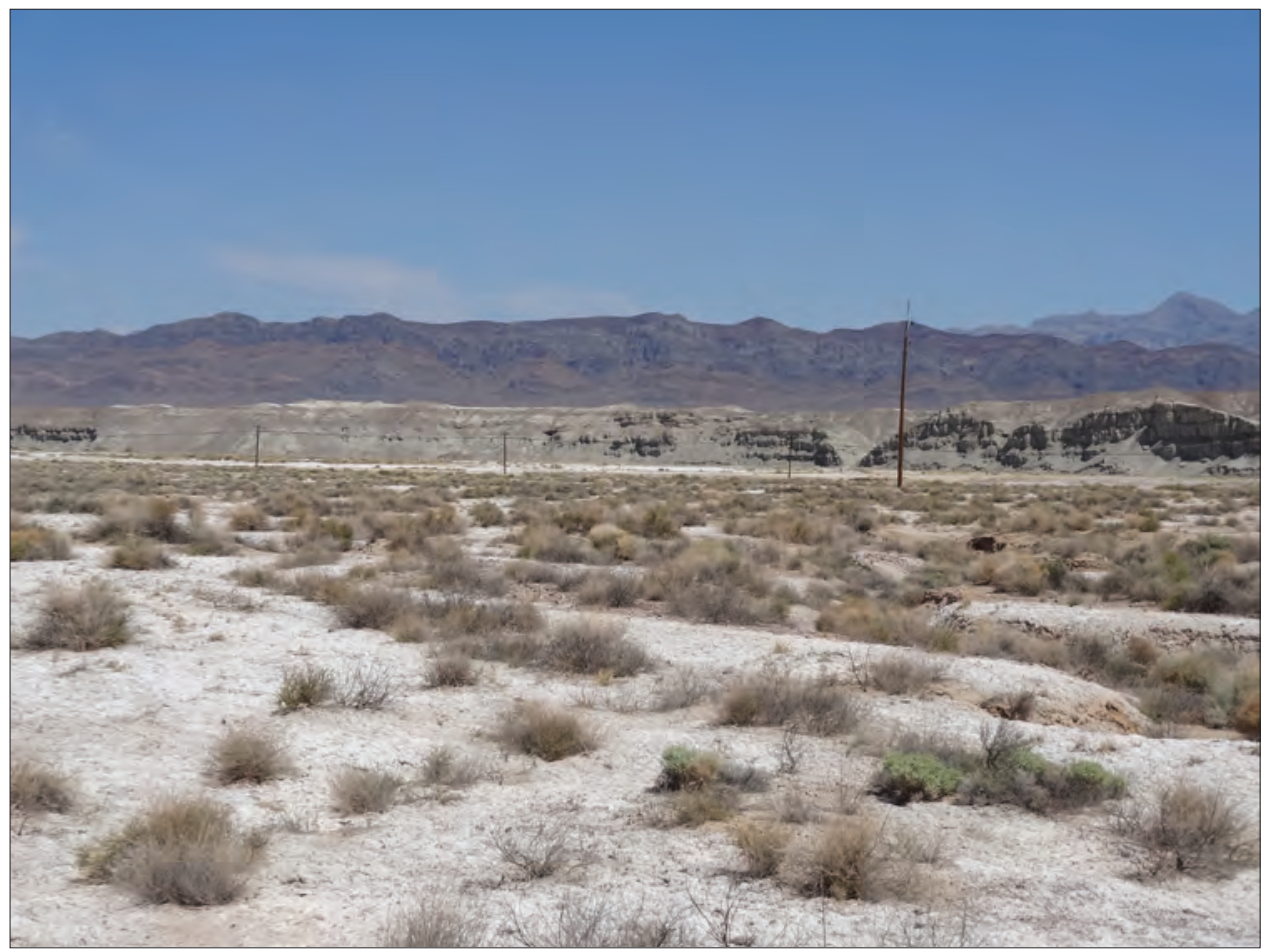

Figure 17. Salt-encrusted area between Borax Spring and the Amargosa River in Lower Amargosa Valley, California, indicating areas of diffuse discharge. View looking northeast toward the Resting Spring Range. Photograph taken by Donald S. Sweetkind, U.S. Geological Survey, April 3, 2015.

Table 6. Annual mean discharge for Amargosa River at Tecopa, California (U.S. Geological Survey site 10251300).

\begin{tabular}{|c|c|c|c|}
\hline $\begin{array}{l}\text { Water } \\
\text { year }^{1}\end{array}$ & $\begin{array}{c}\text { Discharge } \\
\text { (cubic feet per second) }\end{array}$ & $\begin{array}{l}\text { Water } \\
\text { year }^{1}\end{array}$ & $\begin{array}{c}\text { Discharge } \\
\text { (cubic feet per second) }\end{array}$ \\
\hline 1962 & 1.04 & 1992 & 3.38 \\
\hline 1964 & 0.79 & 1994 & 0.22 \\
\hline 1965 & 1.03 & 1995 & 6.36 \\
\hline 1968 & 1.68 & 2002 & 0.72 \\
\hline 1969 & 9.19 & 2003 & 5.23 \\
\hline 1970 & 1.36 & 2004 & 1.26 \\
\hline 1971 & 0.65 & 2005 & 11.10 \\
\hline 1976 & 9.93 & 2009 & 0.53 \\
\hline 1977 & 8.80 & 2010 & 1.52 \\
\hline 1978 & 8.59 & 2011 & 5.04 \\
\hline 1979 & 0.57 & 2012 & 0.37 \\
\hline 1980 & 4.86 & 2013 & 0.69 \\
\hline 1981 & 1.06 & 2014 & 0.61 \\
\hline
\end{tabular}

$1982 \quad 0.95$

${ }^{1}$ A water year begins on October 1 and ends on September 30 of the

$1983 \quad 14.90$


Table 7. Annual mean discharge for Amargosa River above China Ranch Wash near Tecopa, California (U.S. Geological Survey site 10251330).

\begin{tabular}{cc}
\hline $\begin{array}{c}\text { Water } \\
\text { year }^{1}\end{array}$ & $\begin{array}{c}\text { Discharge } \\
\text { (cubic feet per second) }\end{array}$ \\
\hline 2007 & 6.24 \\
2008 & 1.55 \\
2009 & 1.56 \\
2010 & 1.99 \\
2012 & 1.21 \\
2013 & 1.07 \\
2014 & 2.13 \\
\hline
\end{tabular}

${ }^{1} \mathrm{~A}$ water year begins on October 1 and ends on September 30 of the following year. For example, the 2013 water year begins on October 1, 2012, and ends on September 30, 2013.

\section{Synoptic Seepage Run on the Amargosa Wild and Scenic River}

In a synoptic seepage measurement or "run", many different sites along a stream are measured at approximately the same time so that differential measurements can be used to assess the locations and quantities of streamflow along losing and gaining reaches of the stream. Thirty-two synoptic measurement sites (fig. 18) were selected initially, based on the locations of visible spring and groundwater inflows, their actual or perceived accessibility, and the quality of the measurement section (fig. 16). Measurements for the seepage run were made on February 27-28, 2014, because of minimal ET in the LAV (Laczniak and others, 1999, p. 32) and a period of steady base flow during this time. In the downstream part of the study area (fig. 18, sites AR16 to AR32), there were no discernable inflows, so measurement sites were spaced approximately every half mile. There are no diversions from the Amargosa River between the town of Shoshone and Dumont Dunes, and no significant pumping of groundwater occurs in the area (Faunt, D'Agnese, and O'Brien 2010).

\section{Discharge Measurements}

Discharge measurements were made at 30 sites in the study area (fig. 18; table 8). At least two measurements were made at each site except for AR1 and AR4 (fig. 18), where there was no streamflow, AR3 (fig. 18), where flow was estimated, and AR14 and AR15 (fig. 18) due to safety concerns. Measurements were made between 08:54 AM and 4:19 PM (Pacific Standard Time), except for one measurement made at AR15 (fig. 18), which was completed on
February 28, 2013, at 1:24 PM. Sites AR6 and AR27 were not measured due to inaccessibility by field crews.

Fluctuations in streamflow were assessed by examining the discharge in the river at the streamgages and during the seepage run by recording the river stage at selected locations. Discharge at both streamgages (USGS sites 10251300 and 10251330) remained relatively steady for the day with stages ranging plus or minus $0.02 \mathrm{ft}$ (fig. 19).

Data loggers were used to assess the potential for diurnal fluctuations in river stage during the time period of the seepage run (fig. 20). Water levels remained relatively steady at AR11 (fig. 20) and declined by approximately $0.20 \mathrm{ft}$ throughout the day at AR16 and AR21 (fig. 20). Because the stage at AR11 and the two streamgages was relatively stable, the discharge measurements in the upper and middle parts of the AWSR are considered representative of the daily mean discharge at each site. A trend of losing flow downstream from AR16 was expected due to increased ET in these more highly vegetated areas throughout the day; this would result in a diurnal decrease of groundwater discharge to the river. Because no diurnal pattern was apparent, the change in stage during the day was minimal, indicating that the daily discharge was approximately the same. Because of this, measurements made downstream from AR16 are also considered to represent daily mean discharge at each site.

\section{Physical Properties and Alkalinity}

Specific conductance, $\mathrm{pH}$, and water temperature were measured at 27 of the sites (table 8). Alkalinity samples were also collected at seven of the sites and were analyzed in the Nevada Water Science Center laboratory in Henderson, Nev. Plots of specific conductance, temperature, and alkalinity at each site are presented on figure 21 .

Measurements of specific conductance at sites within the study area ranged from 2,630 microsiemens per centimeter $(\mu \mathrm{S} / \mathrm{cm})$ at $25{ }^{\circ} \mathrm{C}$ at AR2 to $11,600 \mu \mathrm{S} / \mathrm{cm}$ at AR5 (table 8). In the AWSR, specific conductance increased downstream from $5,640 \mu \mathrm{S} / \mathrm{cm}$ at AR7 to $5,650 \mu \mathrm{S} / \mathrm{cm}$ at AR32 (fig. 18). Measurements of $\mathrm{pH}$ were consistently above 8 , ranging from 8.2 at the most upstream site, AR2, to 9.0 in the lower reaches of the AWSR (table 8). Temperature readings ranged from $12.0^{\circ} \mathrm{C}$ at $\mathrm{AR} 5$ to $21.5^{\circ} \mathrm{C}$ at AR23. Water temperature appeared to be strongly affected by the time of the measurement, particularly downstream of AR17. Generally, alkalinity values were fairly consistent among the sites, ranging from 831 to 882 milligrams per liter (mg/L) as calcium carbonate (table 8); alkalinity at AR5 was substantially higher $(1,480 \mathrm{mg} / \mathrm{L})$. 


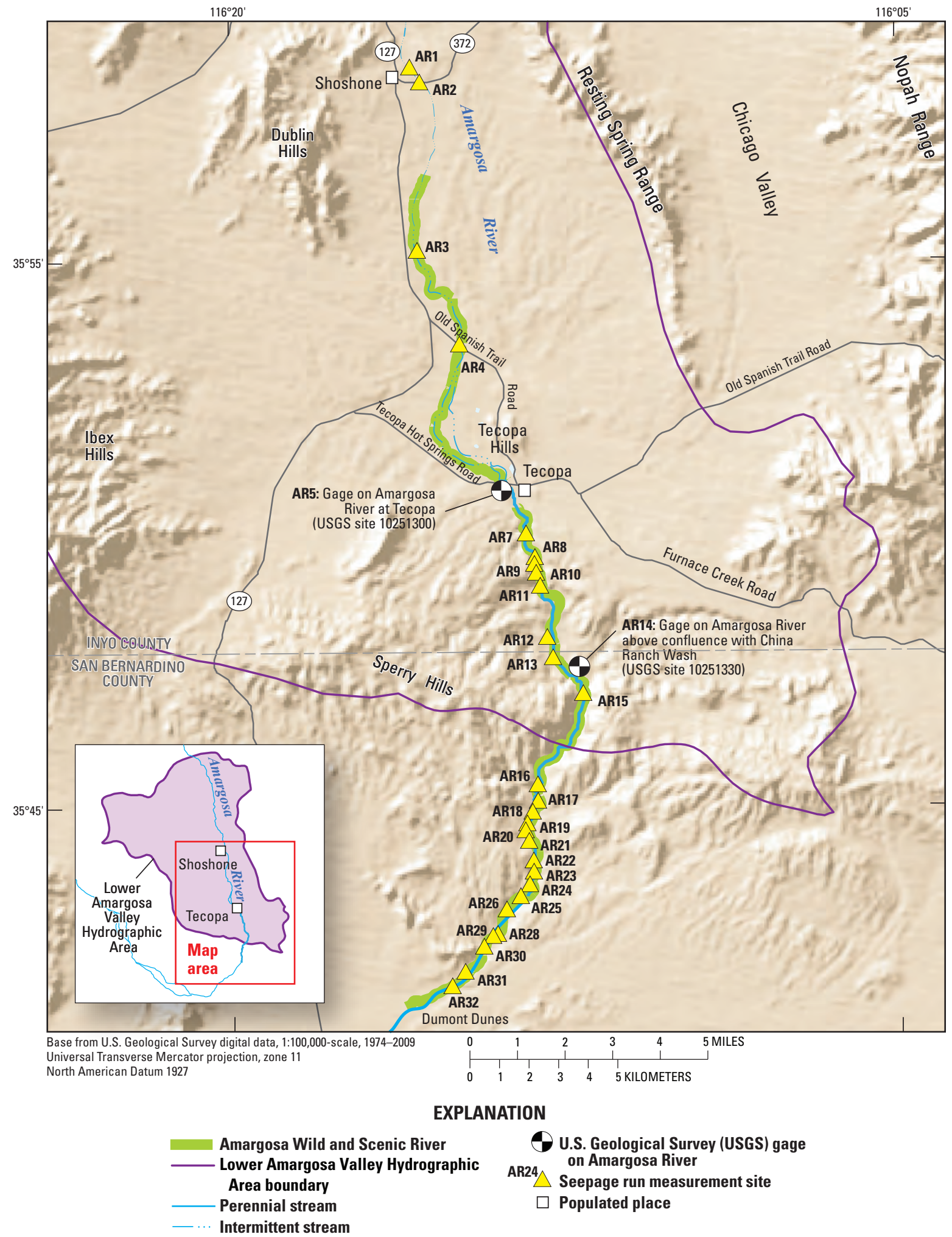

Figure 18. Seepage run measurement sites and streamgages along the Amargosa River from Shoshone to Dumont Dunes, California. 
Table 8. Stream discharge and physical-property measurements from synoptic seepage run sites along the Amargosa Wild and Scenic River, California.

[Downstream distance is measured from the confluence of the Shoshone Spring outlet ditch and the Amargosa River. Abbreviations: $\mathrm{ft}^{3} / \mathrm{s}$, cubic foot per second; ID, identification; mg/L, milligram per liter; USGS, U.S. Geological Survey; $\mu \mathrm{S} / \mathrm{cm}$, microsiemens per centimeter; ${ }^{\circ} \mathrm{C}$, degrees Celsius; - , no data]

\begin{tabular}{|c|c|c|c|c|c|c|c|c|c|}
\hline $\begin{array}{c}\text { USGS site ID } \\
355834116155601\end{array}$ & $\begin{array}{c}\begin{array}{c}\text { Site } \\
\text { name }\end{array} \\
\text { AR1 }\end{array}$ & $\begin{array}{c}\begin{array}{c}\text { Water } \\
\text { temperature } \\
\left({ }^{\circ} \mathrm{C}\right)\end{array} \\
-\end{array}$ & $\begin{array}{c}\text { Specific } \\
\text { conductance }^{2} \\
(\mu \mathrm{S} / \mathrm{cm} \text { at } \\
\left.25^{\circ} \mathrm{C}\right) \\
-\end{array}$ & $\begin{array}{c}\mathrm{pH}^{3} \\
-\end{array}$ & $\begin{array}{c}\begin{array}{c}\text { Discharge } \\
\left(\mathbf{f t}^{3} / \mathbf{s}\right)\end{array} \\
0.00\end{array}$ & $\begin{array}{c}\text { Lab } \\
\text { alkalinity } \\
\text { (mg/L as } \\
\mathrm{CaCO}_{3} \text { ) } \\
-\end{array}$ & Latitude & Longitude & $\begin{array}{c}\text { Downstream } \\
\text { distance } \\
\text { (miles) }\end{array}$ \\
\hline 355817116154201 & AR2 & 17.5 & 2,630 & 8.2 & 0.23 & - & 35.97144 & -116.26175 & 0.43 \\
\hline 355512116154701 & AR3 & 17.0 & 11,500 & 8.9 & 0.10 & - & 35.92004 & -116.26306 & 4.24 \\
\hline 102513005 & AR5 & 12.0 & 11,600 & 8.9 & 0.97 & 1,480 & 35.84861 & -116.22917 & 11.133 \\
\hline - & AR6 & - & - & - & - & - & - & - & - \\
\hline 355001116132301 & AR7 & 15.5 & 5,450 & 8.7 & 2.78 & 861 & 35.83350 & -116.22303 & 12.421 \\
\hline 354935116131101 & AR8 & 14.5 & 5,470 & 8.5 & 2.76 & - & 35.82632 & -116.21972 & 13.018 \\
\hline 354807116125501 & AR12 & 14.0 & 4,640 & 8.5 & 2.31 & - & 35.80188 & -116.21531 & 15.132 \\
\hline 354744116124801 & AR13 & 14.5 & 5,010 & 8.7 & 3.00 & - & 35.79566 & -116.21323 & 15.595 \\
\hline 102513305 & AR14 & 15.0 & 5,430 & 8.5 & 3.11 & 882 & 35.79025 & -116.20533 & 16.202 \\
\hline 354705116120701 & AR15 & 13.0 & - & - & 2.95 & - & 35.78470 & -116.20200 & 16.767 \\
\hline 354525116131001 & AR16 & 13.5 & 5,440 & 8.5 & 2.65 & - & 35.75692 & -116.21931 & 19.279 \\
\hline 354507116130901 & AR17 & 15.0 & 5,570 & 8.6 & 3.33 & - & 35.75185 & -116.21928 & 19.676 \\
\hline 354455116131601 & AR18 & 20.0 & 5,240 & 8.6 & 3.05 & - & 35.74855 & -116.22124 & 19.899 \\
\hline 354442116132401 & AR19 & 20.5 & 5,180 & 8.7 & 2.88 & 857 & 35.74498 & -116.22327 & 20.168 \\
\hline 354435116132601 & AR20 & 20.0 & 5,350 & 8.8 & 3.00 & - & 35.74292 & -116.22397 & 20.355 \\
\hline - & AR27 & - & - & - & - & - & - & - & - \\
\hline 354241116140501 & AR28 & 17.0 & 5,650 & 9.0 & 2.78 & - & 35.71129 & -116.23466 & 23.07 \\
\hline 354238116141101 & AR29 & 20.0 & 5,510 & 9.0 & 2.36 & 831 & 35.71067 & -116.23642 & 23.179 \\
\hline 354227116142301 & AR30 & 21.0 & 5,300 & 9.0 & 2.35 & - & 35.70745 & -116.23982 & 23.494 \\
\hline 354159116144901 & AR31 & 19.0 & 5,460 & 9.0 & 2.19 & - & 35.69986 & -116.24689 & 24.197 \\
\hline 354144116150601 & AR32 & 15.0 & 5,420 & 8.5 & 2.15 & - & 35.69548 & -116.25178 & 24.648 \\
\hline
\end{tabular}

${ }^{1}$ Mean value, rounded to nearest $0.5^{\circ} \mathrm{C}$.

${ }^{2}$ Referenced to $25^{\circ} \mathrm{C}$; mean value rounded to three significant figures.

${ }^{3}$ Mean value, rounded to nearest 0.1 .

${ }^{4} \mathrm{Mean}$ value rounded to three significant figures. 


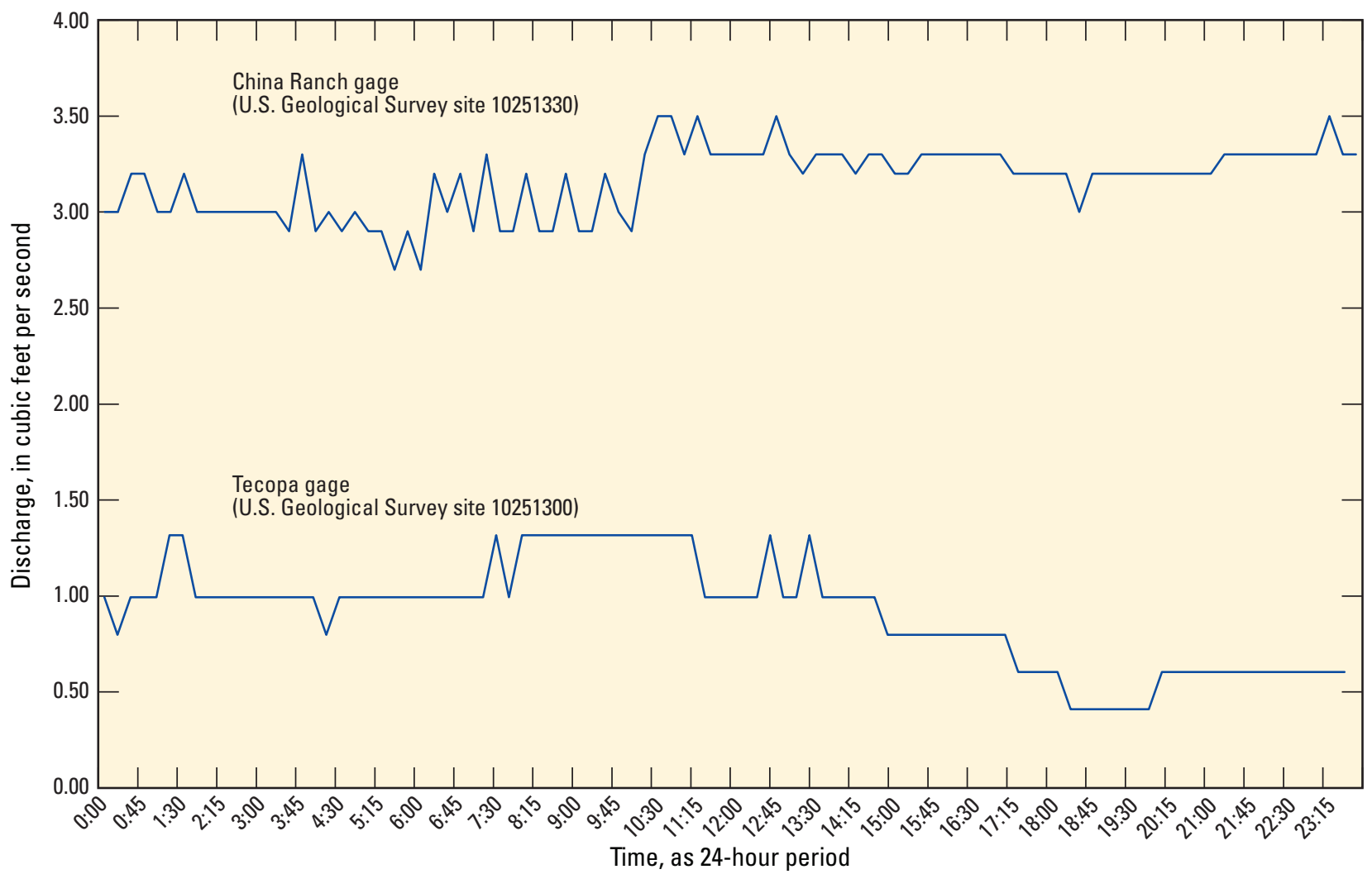

Figure 19. Discharge recorded on February 27, 2014, at U.S. Geological Survey streamgages Amargosa River at Tecopa, California, and Amargosa River above China Ranch Wash near Tecopa, California. 
$\boldsymbol{A}$

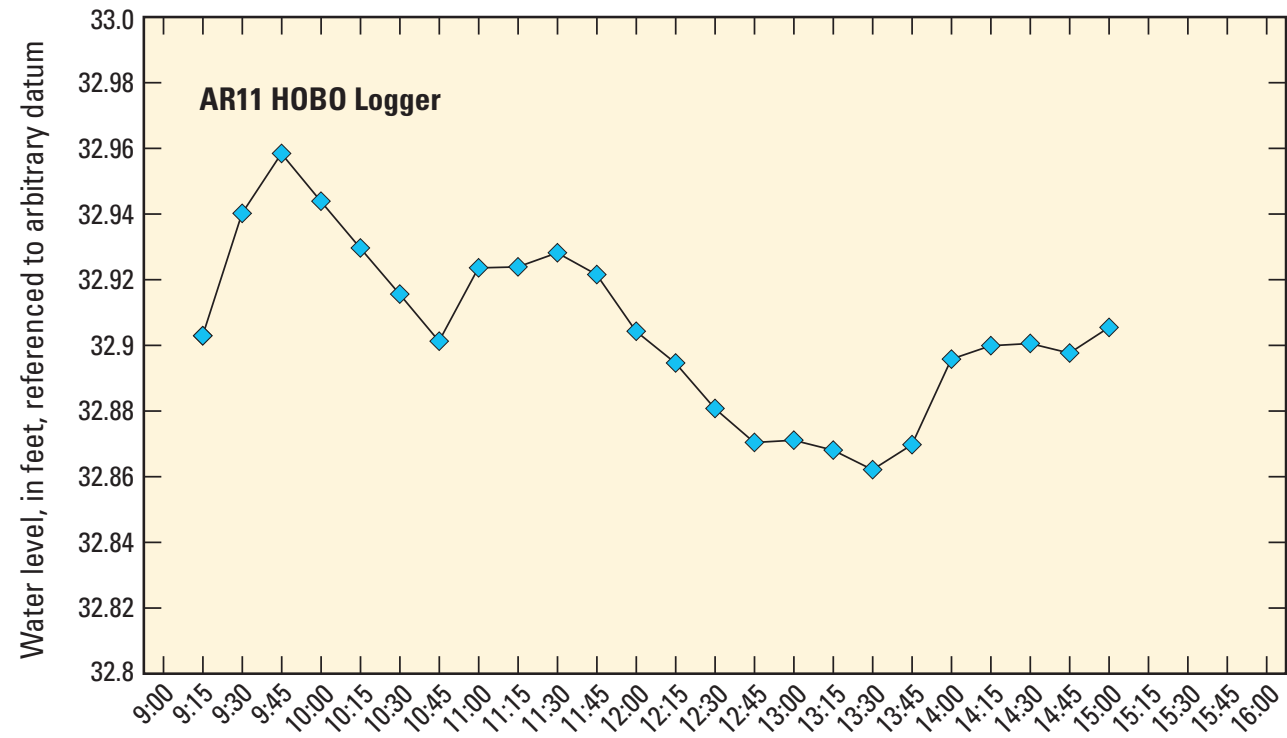

$\boldsymbol{B}$

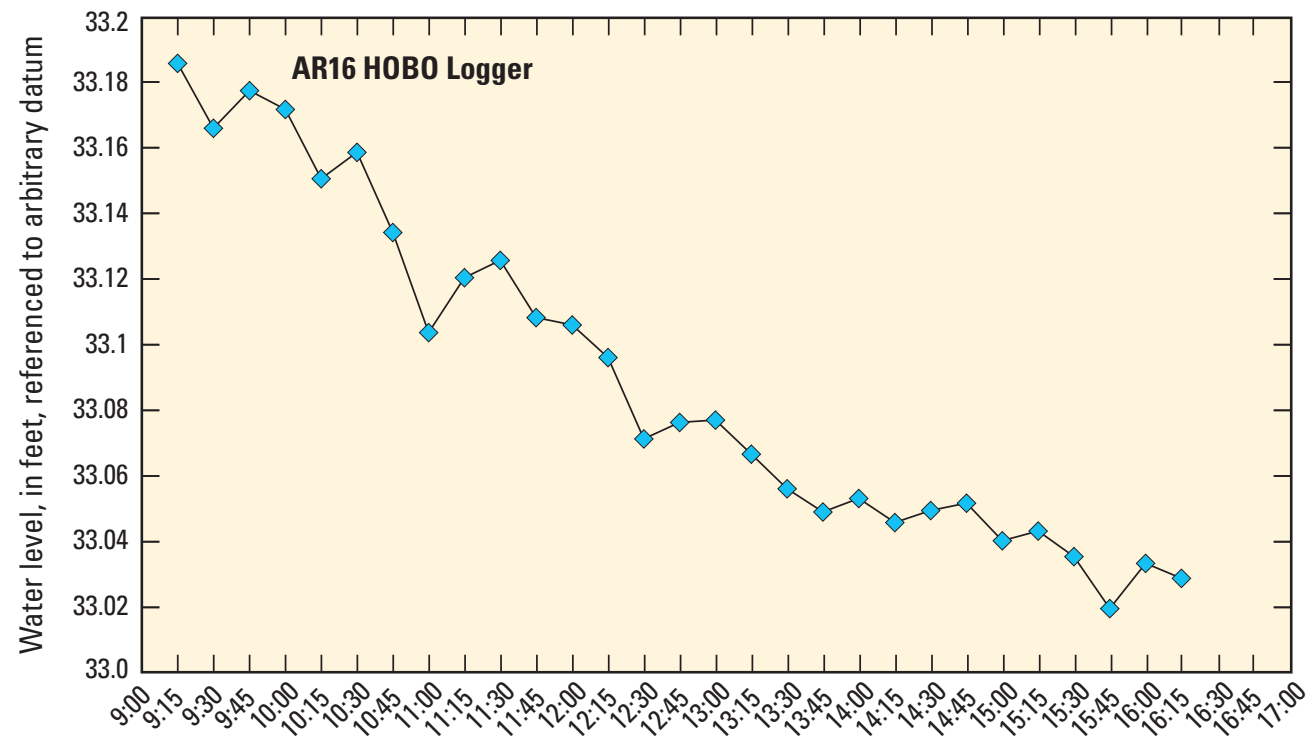

C

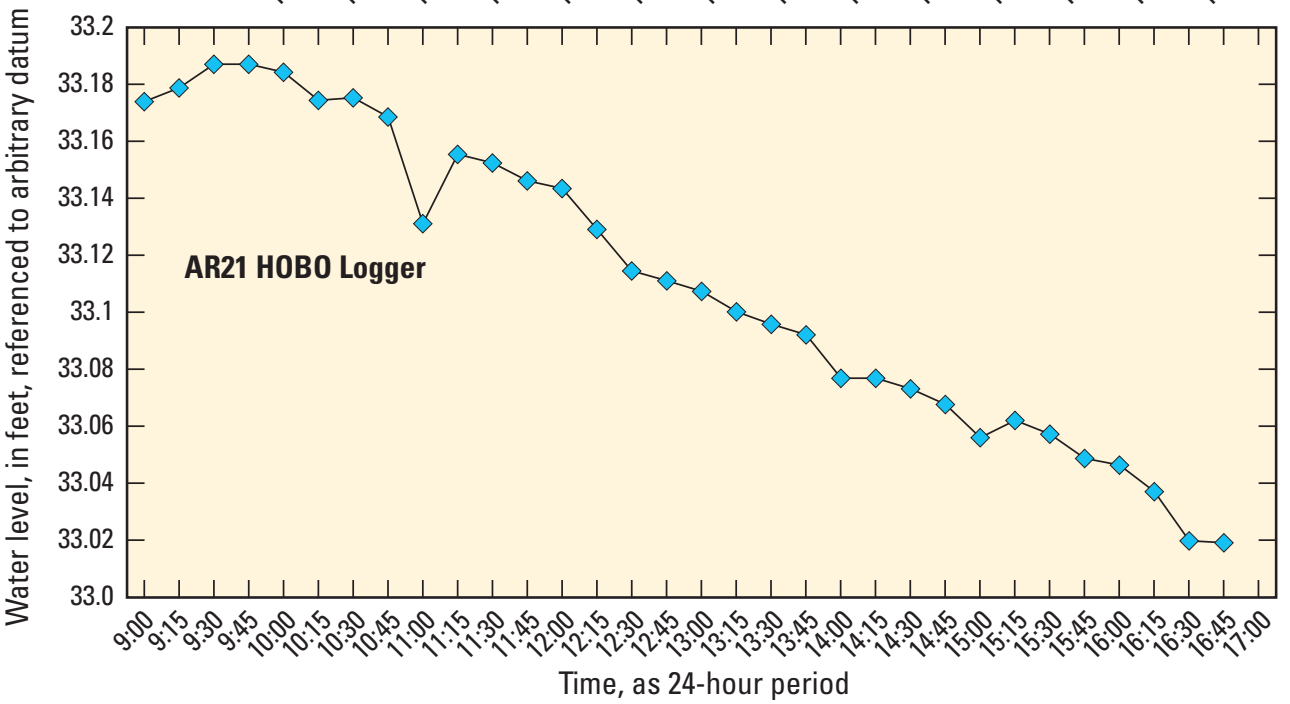

Figure 20. Stream stage measurements over time on February 27, 2014, at seepage run sites $A, A R 11, B, A R 16$, and $C$, AR21, along the Amargosa River, California. 

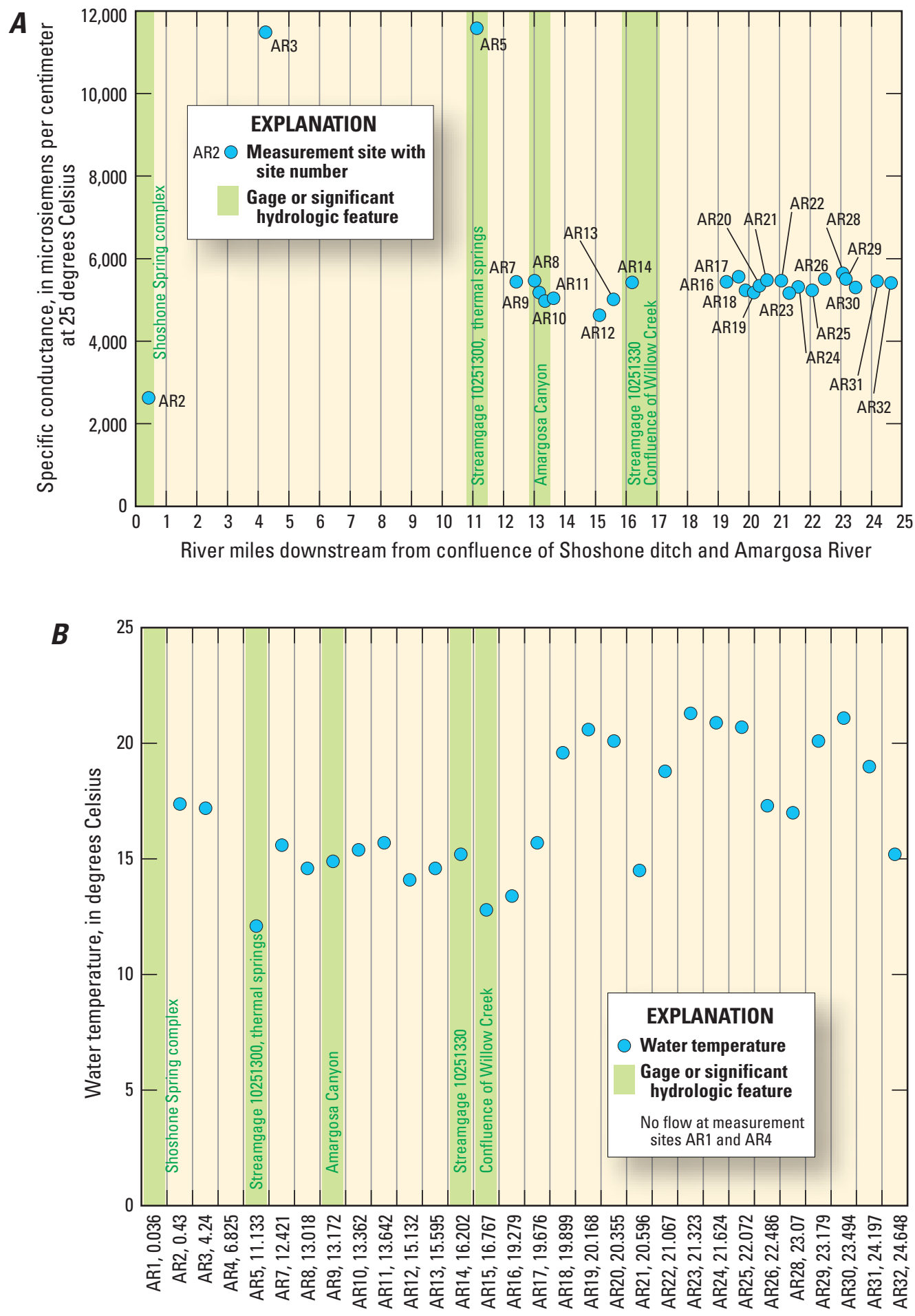

Site number and river mile downstream from confluence of Shoshone ditch and Amargosa River

Figure 21. Measurements made for $A$, specific conductance, $B$, temperature, and $C$, alkalinity, at seepage run sites along the Amargosa River downstream from Shoshone ditch, on February 27-28, 2014. See table 8 for site information. 


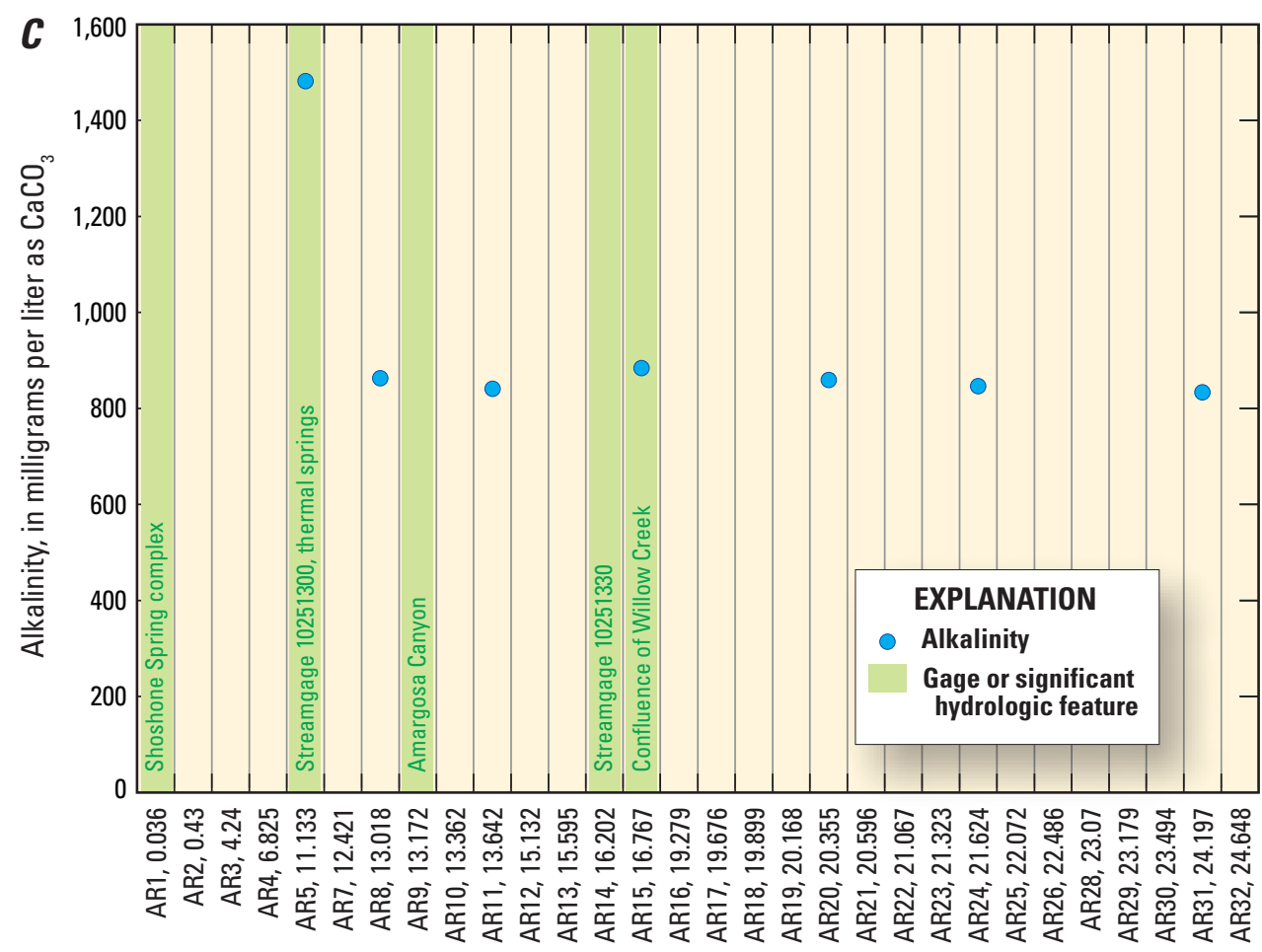

Site number and river mile downstream from confluence of Shoshone ditch and Amargosa River

Figure 21. - Continued

\section{Gains and Losses Along the Amargosa Wild and Scenic River}

The synoptic seepage measurement run indicates three major perennial inflows to the AWSR (fig. 22; pl. 1):

- Shoshone Spring water

- Thermal hot spring water

- Amargosa Canyon water

As mentioned in the "Shoshone Spring" section, approximately 78 percent of the discharge of Shoshone Spring enters the Amargosa River. This spring discharges to the river and flows to AR2 and AR3 before it seeps back into the ground upstream of AR4, where the riverbed is dry and no flow was measured (table 8; pl. 1).

Downstream from AR4, persistent pools are present in the channel (pl. 1). As mentioned previously in the "Discharge Measurements and Observations at SurfaceWater and Discharge Sites" section, there is a northern and southern set of pools (pl. 1); these pools are mostly standing water. The southern persistent pools are located just upstream of the Amargosa River at the Tecopa streamgage (USGS site 10251300, referred to as AR5 in the synoptic seepage run) (table 8; pl. 1). Inflow to the Amargosa River as represented by these persistent pools and from Borehole Spring, become the second major source of water to the perennially flowing section of the Amargosa River. The discharge is substantially greater at AR5 than at the upstream Shoshone Spring inflow at AR2 and AR3 (table 8). Discharge at the Tecopa gage is $0.97 \mathrm{ft}^{3} / \mathrm{s}$ (table 8).

Just downstream from the Tecopa gage (AR5) at site AR7, specific conductivity decreases by nearly 50 percent and the discharge nearly triples (fig. 22), from just under $1 \mathrm{ft}^{3} / \mathrm{s}$ at AR5 to $2.78 \mathrm{ft}^{3} / \mathrm{s}$ at AR7. A major inflow between AR5 and AR7, which could not be accessed on the day of the seepage run due to extremely dense vegetation, is the northern edge of a line of cool springs that enter the Amargosa River in the Amargosa Canyon (fig. 22; pl. 1). The cool springs manifest at sites AR7, AR8, and AR9 and are the third major source of flow to the Amargosa River (fig. 22; pl. 1). The brackish water measured at AR5 is diluted by water with a lower specific conductance from these springs (fig. 21). The source of these springs is likely the same because specific conductivity and water temperature remain nearly the same, even though discharge increases from $2.78 \mathrm{ft}^{3} / \mathrm{s}$ at AR7 to $4.18 \mathrm{ft}^{3} / \mathrm{s}$ at AR9 (fig. 21).

On the downstream section of the Amargosa River from AR16 to AR32, the discharge generally decreases (fig. 22; pl. 1). The riverbed was completely dry near the Dumont Dunes area at the time of the seepage run. There appear to be no significant inflows along the entire downstream part of the river south of its confluence with Willow Creek (AR15). 


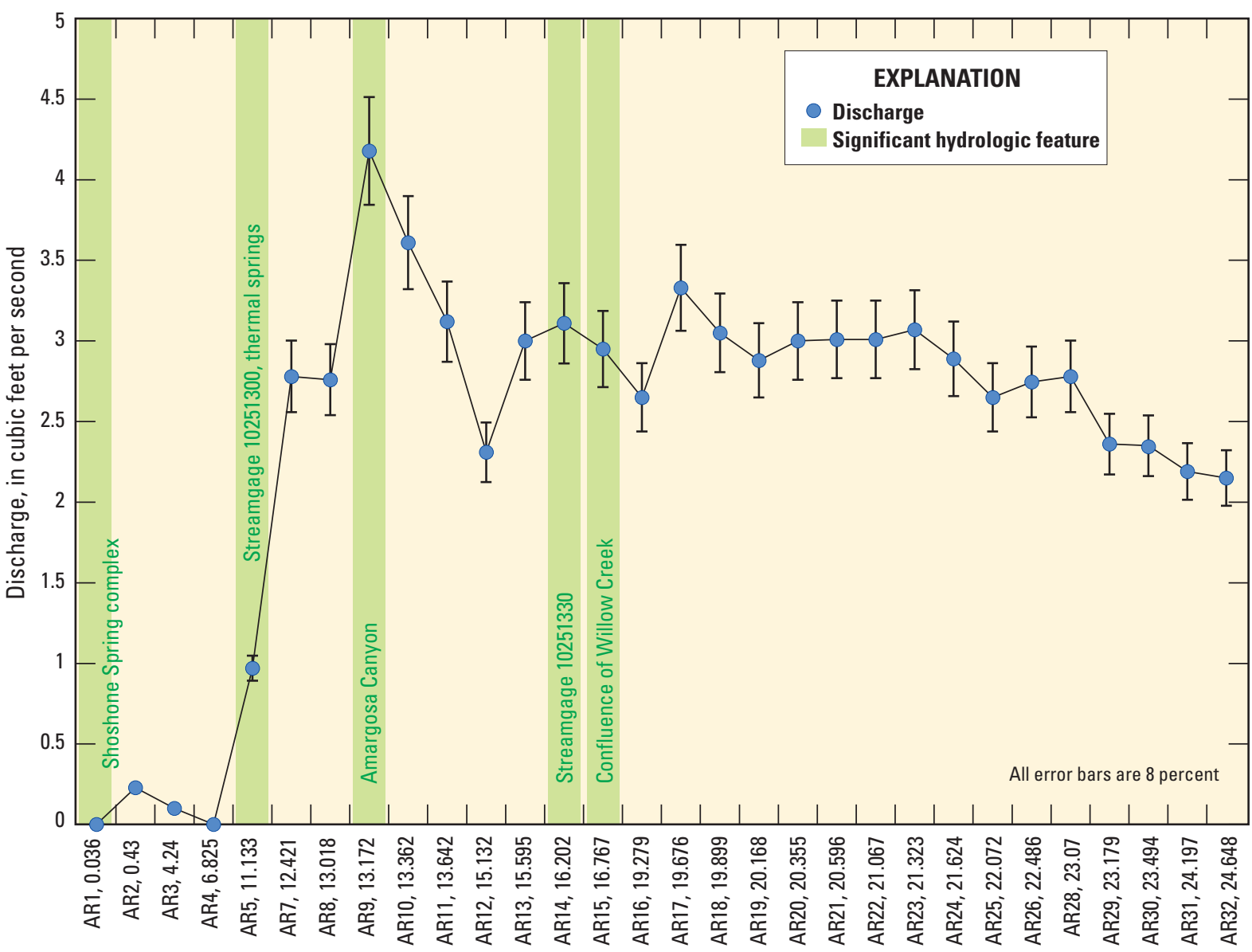

Site number and river mile downstream from confluence of Shoshone ditch and Amargosa River

Figure 22. Discharge measurements made at seepage run sites along the Amargosa River downstream from Shoshone ditch, on February 27-28, 2014. See table 8 for site information.

There may be a relation between areas of the river confined by canyon walls and increases in discharge. On the seepage run, areas that were confined by canyon walls on both sides showed increased discharge, and areas that are more open showed decreased discharge. It is possible that the canyon walls act as a boundary and force flow into the channel, as opposed to when the canyon is more open and more surface water filters into the surrounding alluvium. At AR9, flow increases, then decreases downstream to AR12 as the canyon widens. A similar pattern occurs between AR13 and AR15. As the canyon walls begin to confine the flow again at AR13, flow begins to increase, but as the canyon begins to open up in the vicinity of AR15, flow begins to decrease.

\section{Water Chemistry}

Interpretation of geochemical data can improve understanding of the groundwater flow system because geology, geologic structure, mineralogy, and groundwater flow all influence the chemistry of groundwater. Hydrochemical and isotopic data are useful in distinguishing unique water chemistries and, in some cases, identifying unique flow paths and sources of recharge. Data and interpretations from previous studies discussed below that examined water chemistry in the southern DVRFS, along with geochemical modeling and further interpretation, are used to improve understanding of the LAV groundwater flow system.

Recharged groundwater typically starts as a very dilute calcium-bicarbonate type water and evolves along a flow path before eventually discharging at the surface. Young groundwater has low ionic strength and does not carry the geochemical signature of surrounding aquifer materials as it has not yet interacted with it. As groundwater moves along a flow path, it can dissolve solutes and change from calcium-magnesium-bicarbonate type water, such as that in the Spring Mountains groundwater, to groundwater with more dominant ions that reflect local aquifer materials, as is noted in groundwater farther along the flow path. 


\section{Data Quality, Sources, and Compilation}

Geochemical data, available from previous studies and multiple sources, for samples collected from 1962 to 2014 from sites throughout the LAV and contributing areas exterior to the LAV ("extra-basin" areas) (fig. 23), were reviewed; the resulting data were compiled into a single data set for this study (table 9). Two surface-water grab samples were collected from the Amargosa River as part of this study using protocols outlined in the USGS National Field Manual for the Collection of Water-Quality Data (U.S. Geological Survey, variously dated), and analyzed for major ions and trace elements by the USGS National Water Quality Laboratory (NWQL) in Lakewood, Colorado, and for stable isotopes of oxygen and hydrogen by the Reston Stable Isotope Laboratory in Reston, Virginia. New groundwater samples were not collected for this study.

All water-chemistry data were either reported in previous publications or are available in the USGS National Water Information System (NWIS) database (U.S. Geological Survey, 2014) (table 9) and were combined to make representative samples (table 10). Water-chemistry data were available for the 52-year period, 1962-2014. Generally, groundwater chemistry changes vary little over time (Hem, 1992), and therefore, the results from the historical sampling efforts were considered to be representative of recent conditions and acceptable for the purposes of this study. However, the range of values for several analytes are listed in table 11 to demonstrate the possible range of values at each sample site. Data for this study were chosen to represent the spatial variability of groundwater and different groundwater sources. Many of the historical samples did not include detailed metadata on collection, preservation, or analytical procedures; therefore, the accuracy of the data is difficult to ascertain.

\section{Geochemistry of Groundwater and Springs}

The geochemistry of groundwater in the LAV and extrabasin areas is characterized by the distribution of dissolved gases, solutes, and isotopes in samples, which are controlled by sources and sinks of these constituents that are a function of the geology, mineralogy, land cover and use, and hydrology in the LAV and extra-basin contributing areas. Multiple physical (mixing and evaporation) and chemical (reactions and weathering) processes influence the geochemistry of groundwater. The following discussion describes the physical and chemical characteristics of representative samples (tables 10,11) and geochemical modeling results based on those samples. Dissolved oxygen values varied across the area, but all exceeded $1.0 \mathrm{mg} / \mathrm{L}$, indicating oxidizing conditions. Because of this, enhanced mobilization of redox sensitive elements is not expected.

\section{Stable and Radiogenic Isotopes}

Concentrations of the stable isotopes oxygen-18 and deuterium (hydrogen-2) in water vary in response to sources of precipitation, altitude, season, temperature, amount of evaporation, and other factors (Clark and Fritz, 1997). Radiogenic isotopes, such as hydrogen-3 (tritium) and carbon-14 are often used to evaluate groundwater age. Stable and radiogenic isotopic data were available for numerous samples (table 10). Stable isotopes analyzed in this study were deuterium, oxygen-18, and carbon-13; radiogenic isotopes analyzed were hydrogen-3 (tritium) and carbon- 14 .

The ratios of oxygen-18 and deuterium to their lighter isotopes (hereafter referred to as the isotopic signature) can indicate sources of precipitation or changes to water that have occurred since it existed as precipitation, resulting from processes such as evaporation or water-rock interactions (Coplen, 1993). The Local Meteoric Water Line (LMWL) can be used to describe a continuum in the isotopic signature of local precipitation and its variation from the Global Meteoric Water Line (GMWL) as defined by Craig (1961). Three LMWLs, derived by other researchers, were used to evaluate the isotopic signatures for groundwater, surface water, and precipitation in the LAV study area and adjacent basins (Ingraham and others, 1990; Hershey and others, 2005; Marshall and others, 2012). Together, these LMWLs show the variability in the isotopic signature of precipitation in the region (fig. 24).

Oxygen-18 to oxygen-16 ratios of precipitation samples collected from various locations and altitudes within the LAV and extra-basin areas ranged from -13.9 to -9.19 per mil (\%) and -106 to $-78.4 \%$, respectively (table 10 ). Precipitation sample values span the range of groundwater and surfacewater signatures in the LAV and extra-basin areas, and indicate that precipitation could have a wide range of signatures, depending on the location and altitude at which it fell. Oxygen-18 to oxygen- 16 ratios (reported as $\delta^{18} \mathrm{O}$ ) in groundwater and surface water in the study area ranged from -14.6 to $-11.2 \%$, and deuterium to hydrogen-1 ratios (reported as $\delta^{2} \mathrm{H}$ ) ranged from -107 to $-87.4 \%$ (table 10 ). Most of the samples plot below the LMWL. Spring Mountains samples span a range of values, whereas Ash Meadows samples tightly cluster toward the lower part of the LMWL near samples from the Spring Mountains. Pahrump Valley samples (except site 24) plot in a relatively tight cluster, near the Ash Meadows samples, indicating a similar high-altitude source of recharge for the Pahrump Valley samples (fig. 24). The sample with the lowest $\delta^{18} \mathrm{O}$ value (-14.6\%), from the Stump Spring well, plots near samples from Pahrump Valley and Ash Meadows (Larsen and others, 2001). Chappo (site 30), Wild Bath (site 34), and Thom Springs (site 33) samples plot close to each other and are isotopically heavier than water from Pahrump Valley, indicating that these waters are isotopically similar to Spring Mountains water. Tecopa Hot Springs samples plot near each other, with Borehole Spring plotting very close to the LMWL, whereas Tecopa Hot Springs samples plot below the LMWL. 


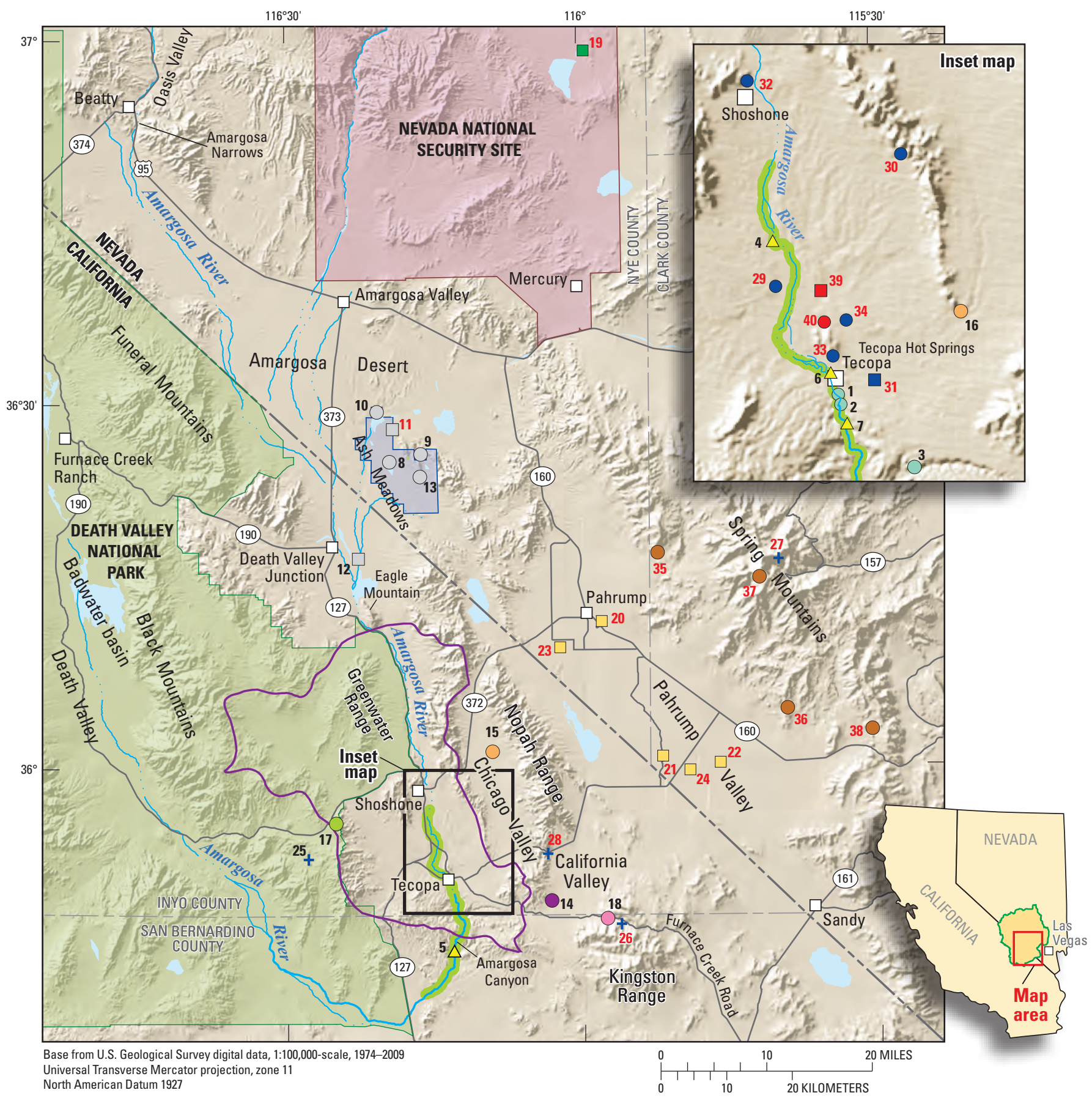

North American Datum 1927

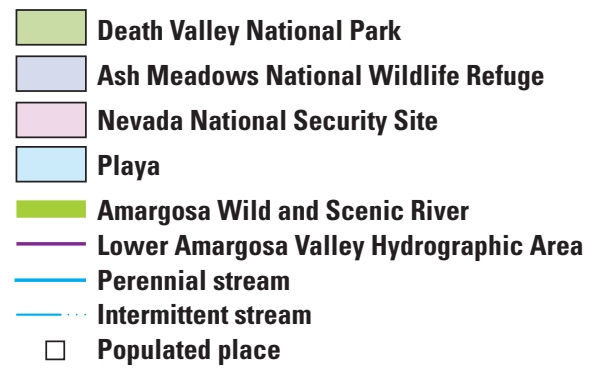

Geochemistry sites - Symbol type denotes type of sample; symbol color denotes geochemical grouping. Number refers to site number in table 10; red numbers identify those samples used in geochemical analysis and modeling

Type of sample and site number

$\mathbf{2 5}+$ Precipitation

$5 \triangle$ River

$14 \bigcirc$ Spring

$24 \square$ Well

\section{Geochemical Group}

Amargosa Canyon

$\triangle$ Amargosa River

$\square \bigcirc$ Ash Meadows

- California Valley

Chicago Valley

Greenwater Range

Kingston Range $\square$ Nevada National
Security Site

Pahrump Valley

+ Precipitation

- Shoshone-Tecopa

Spring Mountains

$\square$ Tecopa Hot Springs

Figure 23. Location and geochemical group for selected representative water-chemistry samples in the Lower Amargosa Valley and extra-basin contributing areas, California and Nevada. 

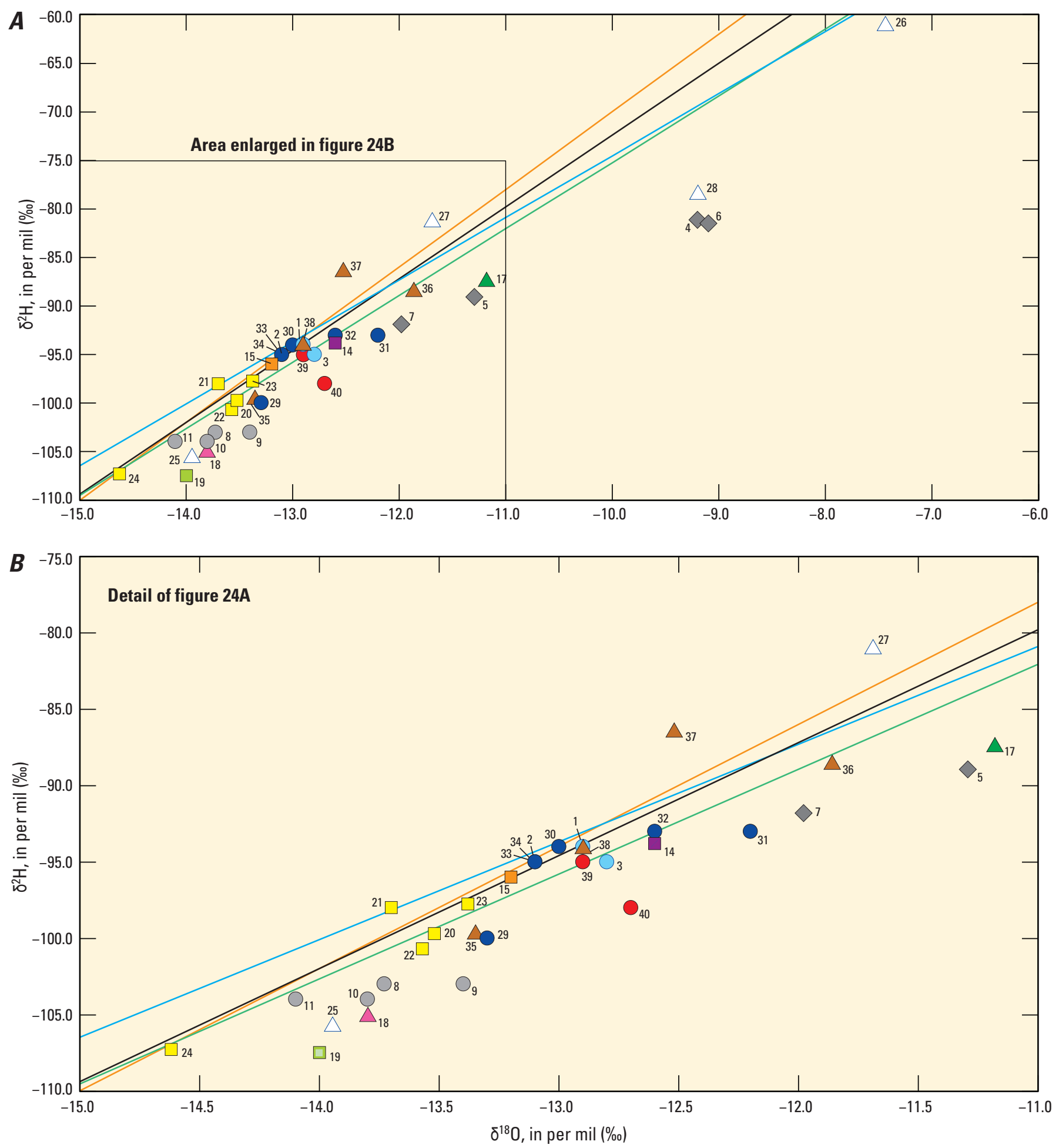

EXPLANATION

\section{— Frenchman Flat Local Meteoric Water Line — Yucca Mountain Local Meteoric Water Line _ Global Meteoric Water Line \\ __ Spring Mountain Local Meteoric Water Line}

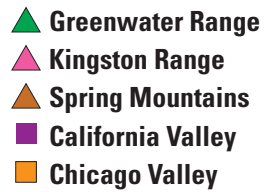

$\square$ Pahrump Valley Amargosa Canyon Ash Meadows Shoshone-Tecopa
Tecopa Hot Springs Nevada National Security Site Amargosa River $\triangle$ Precipitation

Figure 24. Delta deuterium $\left(\delta^{2} \mathrm{H}\right)$ versus delta oxygen-18 $\left(\delta^{18} \mathrm{O}\right)$ for groundwater, surface-water, and precipitation samples plotted on global and local meteoric water lines at $A$, a normal scale, and $B$, an enlarged scale, Lower Amargosa Valley and extra-basin contributing areas, California and Nevada. See table 10 for site reference number and site name. 
Carbon isotopes (carbon-13 and carbon-14) (table 10) can enhance understanding of water-rock interactions and groundwater age. Carbon in groundwater is derived from various components of the carbon cycle, and carbon isotopes can give useful information about interactions between groundwater and the environment. Carbon is introduced to the aquifer through atmospheric and soil carbon dioxide, and it can also be derived from plants, carbonate rocks, and other sources that groundwater may contact in the aquifer (Clark and Fritz, 1997).

The primary method of dating groundwater originating within the 1,000-40,000-year range is carbon-14 (half-life of 5,730 years). Most of the carbon-14 dissolved in groundwater is derived from carbon dioxide present in the soil zone that is incorporated into water as it moves downward into the aquifer as recharge (Drever, 1982, p. 348). Water is characterized as being "modern" if the percent modern carbon (pMC) is greater than 90 (Clark and Fritz, 1997). Young groundwater occurs in samples from the Spring Mountains, Kingston Range, and Greenwater Range (table 9); the pMC for samples representative of the Spring Mountains was highly variable ( 45 to $98 \mathrm{pMC}$ ). Generally, carbon-14 values were low (table 10,2.8 to $11.2 \mathrm{pMC}$ ) in the northern part of the region (Ash Meadows and the NNSS) and low to intermediate (6.9 to 50.5 pMC) in Pahrump and Chicago Valleys. Some samples that have young water are most likely a mix of modern and premodern water. No carbon-14 samples were analyzed from the Shoshone-Tecopa area or Amargosa Canyon.

The tritium isotope, ${ }^{3} \mathrm{H}$, has short-lived (half-life of 12.43 years) and is commonly used to identify young groundwater by providing an estimate of the time the sample was last in contact with the atmosphere (Clark and Fritz, 1997). Tritium concentrations in samples greater than 0.8 tritium units (TU) indicate modern (post-1950s) recharge or mixing with modern waters (Clark and Fritz, 1997). Samples from the Kingston Range, Greenwater Range, and Spring Mountains ranged from less than $5 \mathrm{TU}$ to $14 \mathrm{TU}$, and most mountainous sites had detectable tritium. However, samples from most sites at lower altitudes had tritium concentrations ranging from below the detection limit (varies depending on sample year and analytical method) to $0.5 \mathrm{TU}$. Water from sites in the LAV ranged from below the detection limit to $2.8 \mathrm{TU}$, indicating at least a component of modern (post-1950s) water at some of these sites.

\section{Saturation Indices}

Thermodynamic conditions in the aquifer environment were evaluated to assess whether groundwater compositions were saturated, undersaturated, or in equilibrium with respect to selected minerals. The thermodynamic state of each water composition was calculated by using the WATEQ4F thermodynamic database (Ball and Nordstrom, 1991) in PHREEQC (Parkhurst and Appelo, 2013). The saturation indices (SIs) for water samples evaluated as part of this study are shown in table 12. Positive and negative SIs indicate supersaturation (mineral may precipitate) and undersaturation (mineral may dissolve), respectively. Saturation indices of $0 \pm 0.1$ were interpreted as indicating that the mineral was in equilibrium with a water composition (table 12).

The calculated SIs for anhydrite, fluorite, gypsum, amorphous silica, and halite were negative in all samples, indicating that these minerals may possibly dissolve, releasing ions into solution. Meanwhile, SIs for quartz were all positive, indicating that quartz will only precipitate from solution. Calcite and amorphous silica were in equilibrium in some samples. Sites where water is at or above saturation with respect to calcite may be representative of the carbonaterock aquifer where these minerals are typically at or above saturation (Hershey and others, 2010).

\section{Chemistry of Groundwater Groups}

\section{Temperature and Specific Conductance}

Temperature and specific-conductance values vary among water groups (fig. 25). The temperature of groundwater from springs varied throughout the study area from 4.7 to $44^{\circ} \mathrm{C}$. The highest groundwater temperatures were observed in the Tecopa Hot Springs samples $\left(39\right.$ to $44^{\circ} \mathrm{C}$ ), representative of a deep circulating thermal system. Observed water temperatures may have been influenced by air temperature, depending on the water source and sampling technique. Specific conductance of water collected from springs in the LAV varied notably among geographic areas, (table 11; figs. 6, 7; pl. 1).

Specific conductance of water samples from higher altitudes (Spring Mountains, Greenwater Range, and Kingston Range) ranged from 130 to $630 \mu \mathrm{S} / \mathrm{cm}$ at $25^{\circ} \mathrm{C}$. Specific conductance of water samples from springs in the Amargosa Canyon ranged from 1,000 to $1,300 \mu \mathrm{S} / \mathrm{cm}$, whereas springs composing the Shoshone-Tecopa sample group ranged from 760 to 3,000 $\mu \mathrm{S} / \mathrm{cm}$. Borehole Spring and Tecopa Hot Springs samples had specific-conductance values of 4,200 and $6,400 \mu \mathrm{S} / \mathrm{cm}$, respectively.

Groundwater samples collected in mountainous terrains tended to be cooler and lower in specific conductance than groundwater samples from the valleys because these waters are (1) from higher altitudes (cooler), and (2) near the beginning of their groundwater flow path and have had little interaction with aquifer materials. As groundwater moves from the mountains into the valleys, many minerals dissolve, resulting in increased specific-conductance values. Temperatures of water from valley springs in the south-central Great Basin, Nevada and California, typically range from 24 to $35^{\circ} \mathrm{C}$ (Winograd and Thordarson, 1975). San Juan and others (2010) showed that large-volume springs in the region within this temperature range are discharging from the regional carbonate-rock aquifer. Samples from Wild Bath Spring and Tecopa Hot Springs exceed $35^{\circ} \mathrm{C}$. Samples from Tecopa Hot Springs have the highest measured temperatures and conductance values of all samples collected during this study and appear to be quite different than the regional carbonate springs. These high conductance values likely result from high temperatures allowing increased mineral solubility. 
Table 12. Saturation indices for selected minerals for groundwater samples, Lower Amargosa Valley and extra-basin contributing areas, California and Nevada.

[Saturation indices are the $\log 10$ of the ratio of an ion-activity product of a solution for a specific mineral and the equilibrium constant for the mineral. Negative saturation indices indicate that the water sample is undersaturated with respect to that mineral. Positive saturation indices indicate that the water sample is oversaturated with respect to that mineral. Abbreviations: am, amorphous; $\mathrm{CO}_{2}$, carbon dioxide; $\mathrm{SiO}_{2}$, silicon dioxide; —, no data]

\begin{tabular}{|c|c|c|c|c|c|c|c|c|c|}
\hline Site name & Anhydrite & Calcite & $\mathrm{CO}_{2}$ & Dolomite & Fluorite & Gypsum & Halite & Quartz & $\mathrm{SiO}_{2}(\mathrm{am})$ \\
\hline 162 S20 E 5323 ABAD1 U19 & -2.67 & -0.42 & -1.84 & -0.8 & -2.76 & -2.35 & -9.51 & 0.26 & -1.02 \\
\hline Amargosa Canyon Spring 1 & -2.03 & 1.03 & -3.22 & 2.25 & -0.55 & -1.71 & -6.71 & 0.89 & -0.39 \\
\hline Amargosa Canyon Spring 4 & -1.95 & 0.86 & -2.77 & 1.98 & -0.48 & -1.66 & -6.58 & 0.65 & -0.61 \\
\hline Borax Spring & -4.59 & ${ }^{1}-0.07$ & -4.52 & ${ }^{1}-0.06$ & -2.17 & -4.35 & -5.83 & 0.60 & -0.63 \\
\hline Borehole Spring & -2.57 & 0.35 & -2.80 & 0.60 & -1.71 & -2.51 & -5.07 & 0.79 & -0.34 \\
\hline Chappo Spring & -2.17 & -0.75 & -1.45 & -1.31 & -0.83 & -1.91 & -6.98 & 0.68 & -0.57 \\
\hline Crystal Pool & -2.11 & ${ }^{1}-0.01$ & -1.84 & ${ }^{1} 0.02$ & -0.85 & -1.87 & -7.37 & 0.53 & -0.70 \\
\hline Crystal Spring & -2.43 & -0.94 & -1.79 & -2.00 & -4.09 & -1.98 & -8.11 & 0.76 & -0.60 \\
\hline Cynthia's well & -2.25 & 0.63 & -3.08 & 1.58 & -0.77 & -1.90 & -6.60 & 1.07 & -0.22 \\
\hline Devils Hole well (AM-4) & -2.06 & -0.49 & -1.58 & -0.94 & -0.97 & -1.84 & -7.44 & 0.43 & -0.79 \\
\hline Fairbanks Spring & -2.15 & ${ }^{1} 0.10$ & -1.92 & 0.19 & -0.72 & -1.87 & -7.41 & 0.53 & -0.72 \\
\hline Five Springs well (AM-2) & -2.08 & 0.41 & -2.07 & 0.84 & -0.89 & -1.87 & -7.47 & 0.43 & -0.78 \\
\hline Hidden Hills Ranch well & -2.25 & -0.18 & -1.87 & -0.36 & -1.90 & -1.94 & -8.97 & 0.92 & -0.35 \\
\hline Hog Farm well & -3.54 & -1.68 & -1.35 & -3.08 & -1.15 & -3.15 & -6.42 & 0.72 & -0.55 \\
\hline Horse Springs & -3.04 & 0.22 & -2.44 & 0.34 & - & -2.62 & -9.04 & 0.43 & -0.90 \\
\hline Jeep Trail well & -2.49 & ${ }^{1}-0.03$ & -2.75 & ${ }^{1} 0.00$ & -2.94 & -2.16 & -9.27 & 0.53 & -0.75 \\
\hline Lost Cabin Spring & -1.99 & -0.26 & -2.30 & -0.63 & -1.98 & -1.57 & -8.22 & 0.67 & -0.67 \\
\hline Nevada National Security Site well & -2.48 & ${ }^{1}-0.05$ & -1.83 & ${ }^{1}-0.05$ & -1.74 & -2.35 & -7.72 & 0.44 & -0.73 \\
\hline Peak Spring & -3.60 & -0.36 & -2.87 & -1.34 & -3.56 & -3.07 & -10.96 & 0.13 & -1.28 \\
\hline Point of Rocks Spring & -2.09 & -0.12 & -1.80 & -0.20 & -0.98 & -1.86 & -7.66 & 0.46 & -0.76 \\
\hline NC-GWE-PV-04 & -2.96 & ${ }^{1} 0.06$ & -2.64 & 0.63 & -1.87 & -2.62 & -9.06 & 0.79 & -0.50 \\
\hline Rainbow Spring & -3.04 & ${ }^{1} 0.05$ & -1.94 & ${ }^{1} 0.10$ & -2.72 & -2.60 & -9.07 & 0.48 & -0.88 \\
\hline Resting Spring & -2.31 & 0.59 & -3.10 & 1.57 & -0.93 & -2.03 & -6.80 & 0.97 & -0.29 \\
\hline Salsberry Spring & -3.64 & -1.63 & -1.96 & -3.94 & -2.39 & -3.19 & -7.58 & 0.96 & -0.40 \\
\hline Shoshone Spring & -1.80 & 0.43 & -2.31 & 1.02 & -0.79 & -1.59 & -6.12 & 0.67 & -0.54 \\
\hline Stump Spring well & -2.62 & -0.58 & -2.64 & -1.03 & -2.45 & -2.30 & -9.55 & 0.60 & -0.68 \\
\hline Tecopa Hot Springs & -2.85 & ${ }^{1} 0.02$ & -2.89 & -0.34 & -1.81 & -2.69 & -4.98 & 0.89 & -0.29 \\
\hline Thom Spring & -2.14 & ${ }^{1}-0.05$ & -2.05 & 0.13 & -0.88 & -1.84 & -6.14 & 1.11 & -0.16 \\
\hline Tule Spring & -2.08 & -0.27 & -2.17 & -0.67 & -0.87 & -1.60 & -7.15 & 1.05 & -0.33 \\
\hline Twelvemile Spring & -2.15 & -0.14 & -2.48 & -0.23 & -0.82 & -1.82 & -7.02 & 1.29 & ${ }^{1} 0.00$ \\
\hline Wild Bath Spring & -2.07 & 0.33 & -2.28 & 0.85 & -1.16 & -1.90 & -6.13 & 0.99 & -0.19 \\
\hline Willow Spring & -1.75 & 0.94 & -2.91 & 2.05 & -0.46 & -1.44 & -6.82 & 0.87 & -0.41 \\
\hline
\end{tabular}

\footnotetext{
${ }^{1}$ Samples are neither undersaturated nor oversaturated with respect to that mineral.
} 


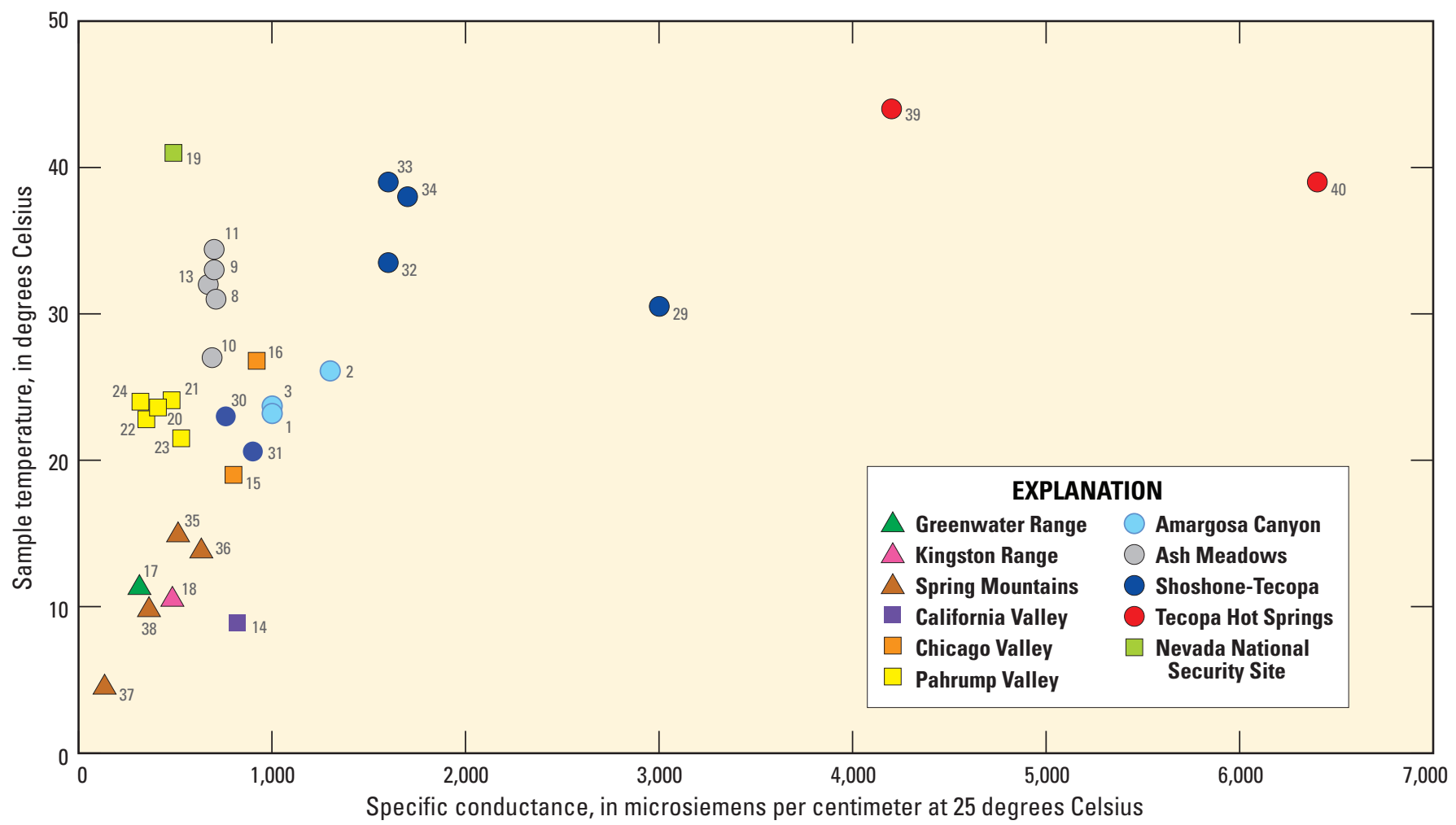

Figure 25. Water temperature versus specific conductance for groundwater samples in the Lower Amargosa Valley and extra-basin contributing areas, California and Nevada. See table 10 for site reference number and site name.

\section{Major lons and Hydrochemical Facies}

Groundwater accumulates solutes with distance travelled along a groundwater flow path. Previous investigations in this study area noted that as water moves downgradient, sodium, potassium, chloride, fluoride, and sulfate concentrations increase, showing the influence of dissolution of minerals such as gypsum and halite, and precipitation of carbonate minerals such as calcite (Hershey and others, 2010). The high specific-conductance values (general over $1,500 \mu \mathrm{S} / \mathrm{cm}$ ) and elevated concentrations of chloride, sodium, boron, and sulfate in the Shoshone-Tecopa sample group are most likely due to interaction with playa-accumulated evaporites (Larsen and others, 2001; Davisson, 2015), such as the Tecopa lake beds and China Ranch beds. Wild Bath Spring, Borax Spring, and Thom Spring are located on or adjacent to Tecopa lake bed deposits. Shoshone Spring is located near Tecopa lake bed deposits, and groundwater flowing to this spring also may have interacted with them; however, specific-conductance values of other Shoshone-Tecopa samples do not indicate interaction with these lake bed deposits.

Chloride concentrations vary greatly throughout the LAV and extra-basin areas, and can be used as an indicator of geochemical evolution because it demonstrates conservative geochemical behavior (Hem, 1992). Concentrations of chloride in groundwater samples collected from the LAV and extra-basin areas could be influenced by atmospheric inputs, anthropogenic inputs, and/or mixing with formation waters or evaporites (Edmunds and Smedley, 2000). Recharge water has typically low chloride concentrations. Chloride concentrations in water samples collected from the Greenwater Range, Kingston Range, and Spring Mountains ranged from 0.45 to $65 \mathrm{mg} / \mathrm{L}$ (table 10). A water sample collected from a well at the nearby NNSS, had a chloride concentration of $13 \mathrm{mg} / \mathrm{L}$; the main source of chloride in recharge to this well is atmospheric deposition (dry and wet fall) and the contribution from rock-water interaction is negligible (Marshall and others, 2012). Evaporite deposits in Pahrump Valley, Ash Meadows, and the Amargosa Desert all have the potential to contribute large amounts of chloride. Samples in the Shoshone-Tecopa group, as well as those from Tecopa Hot Springs, have the highest chloride and specific-conductance values of all samples included for analysis, quite possibly from localized interaction with evaporites in the Tecopa lake beds (Zdon and others, 2015).

Water type can indicate the relative position of a sample along a flow path. Water types identified in previous studies from surrounding areas were plotted on figure 26, along with samples from this study. Atmospheric precipitation in the southern DVRFS has been inferred to be a calcium-bicarbonate type water, with very low ionic strength, based on a precipitation chemistry monitoring station in the Kawich Range (Marshall and others, 2012). 
Recharge waters sampled from the Spring Mountains are calcium-magnesium-bicarbonate type (Davisson, 2015). Groundwater in Pahrump Valley, downgradient of the Spring Mountains, is a calcium-magnesium-bicarbonate or similar type water such as calcium-bicarbonate or magnesiumcalcium-bicarbonate (Winograd and Thordarson, 1975; Davisson, 2015), similar to the findings of this study (table 10). Regional non-carbonate water sourced from recharge into volcanic rocks, such as that found in the upper Amargosa Desert (south of the NNSS) and near the NNSS (Oasis Valley and Jackass Flats) is a sodium-potassiumbicarbonate type water (Winograd and Thordarson, 1975; Hershey and Acheampong, 1997; Hershey and others, 2010; Belcher and Sweetkind, 2010; Davisson, 2015) with sodium and potassium concentrations increasing downgradient with continued dissolution of volcanic rocks and silicate minerals and further mixing with water from volcanic-rock aquifers (Davisson, 2015). Water in the regional carbonate-rock aquifer is a calcium-magnesium-bicarbonate type (Belcher and Sweetkind, 2010; Davisson, 2015), and is controlled by carbonate mineral equilibria and the source of recharge water (Winograd and Thordarson, 1975; Claassen, 1985; Thomas and others, 2002). Water type at Ash Meadows is consistent with regional carbonate-rock aquifer water that has been influenced by sodium and sulfate from volcanic rocks at the NNSS (Winograd and Thordarson, 1975; Davisson, 2015). This mixing creates a calcium-magnesiumsodium-bicarbonate, a sodium-potassium-bicarbonate, or a magnesium-bicarbonate type water (Thomas and others, 1996; Marshall and others, 2012).

Samples from surrounding areas that were evaluated in this study tend to plot in previously identified water type groupings (groups 1-5). However, samples from the LAV (Greenwater Range, Amargosa Canyon, Shoshone-Tecopa, Tecopa Hot Springs, and Amargosa River) are characterized by a variety of water types in groups 1,2, or 3 (fig. 26). Shoshone-Tecopa groundwater samples collected from Wild Bath Spring (site 34), Thom Spring (site 33), and Cynthia's well (site 31) are characterized as a sodium-bicarbonatesulfate type water. This water type is distinctly higher in sodium and sulfate than in samples from Ash Meadows, the regional carbonate-rock aquifer, Pahrump Valley, and Spring Mountains waters, which would be expected of a water that has been influenced by evaporites in the Tecopa lake beds. Cynthia's well (site 31) is not in the vicinity of the Tecopa lake beds, but likely receives water from an upgradient area that was influenced by these deposits. The solubility of calcite decreases with increasing temperature, which may help to explain why the warm waters in the Shoshone-Tecopa area, as well as those from the carbonate-rock aquifer, tend to have lower concentrations of calcium (fig. 26). The Shoshone
Spring sample (site 32) plots near samples from Thom Spring (site 33), Wild Bath Spring (site 34), and Cynthia's well (site 31), but shows a greater amount of chloride, resulting in a sodium-bicarbonate-sulfate-chloride type water (fig. 26). Chappo Spring (site 30) is characterized as a sodiummagnesium-calcium-bicarbonate-sulfate type water.

Other samples from the LAV plot differently than regional samples. Samples from Amargosa Canyon Springs 1 and 4 (sites 1 and 2, respectively) plot as sodium-bicarbonatesulfate type water similar to the Shoshone-Tecopa group samples (sites 31, 33, and 34). Willow Spring (site 3) plots as a sodium-magnesium-calcium-sulfate-bicarbonate type water. As Larsen and others (2001) note, the Tecopa Hot Springs samples (sites 39 and 40) have an entirely unique chemistry, characterized by a dominance of sodium-chloride-sulfatebicarbonate type water and being alkaline along with elevated dissolved-solids concentrations.

\section{Ratios of Elements as a Tracer}

Ratios of dissolved constituents can help to discern patterns among various water groups. Strontium to calcium $(\mathrm{Sr} / \mathrm{Ca})$ ratios can be used to identify the extent of waterrock interaction in a sample. Strontium can replace calcium and magnesium in carbonate minerals, so it should increase as carbonate minerals dissolve (Hershey and others, 2010). Calcite can back-precipitate out of solution, which lowers the calcium content of waters (Edmunds and Smedley, 2000), and strontium that has been dissolved into groundwater does not precipitate, increasing its presence in relation to calcium (Hershey and others, 2010). Groundwater that has undergone very little water-rock interaction will have lower $\mathrm{Sr} / \mathrm{Ca}$ ratios (less than 0.02), as noted in samples from the Spring Mountains (sites 35-38), NNSS (site 19), Pahrump Valley (sites 20-24), and the Greenwater Range (site 17). Samples from Ash Meadows (sites 8-13) have $\mathrm{Sr} / \mathrm{Ca}$ ratios between 0.017 and 0.094 , indicating limited water-rock interaction or that waters that never became fully saturated with calcium. The Shoshone-Tecopa sample group (sites 29-34) has $\mathrm{Sr} / \mathrm{Ca}$ ratios from 0.025 to 0.15 , indicating that these samples have undergone a greater amount of water-rock interaction (fig. 27). Tecopa Hot Springs samples (sites 39 and 40 ) had $\mathrm{Sr} / \mathrm{Ca}$ ratios of 0.024 and 0.039 , respectively, falling in the same range as the Shoshone-Tecopa sample group (sites 29-34). Hershey and others (2005) observed lower $\mathrm{Sr} / \mathrm{Ca}$ ratios in samples from the NNSS (mean ratio of 0.0038), whereas samples from the regional carbonate-rock aquifer in the northern part of the region ranged from 0.010 to 0.018 (fig. 27), indicating less water-rock interaction upgradient along potential flow paths into the LAV. Alluvial/basin-fill groundwater north of the study area had $\mathrm{Sr} / \mathrm{Ca}$ ratios of approximately 0.0058 (Hershey and others, 2005). 


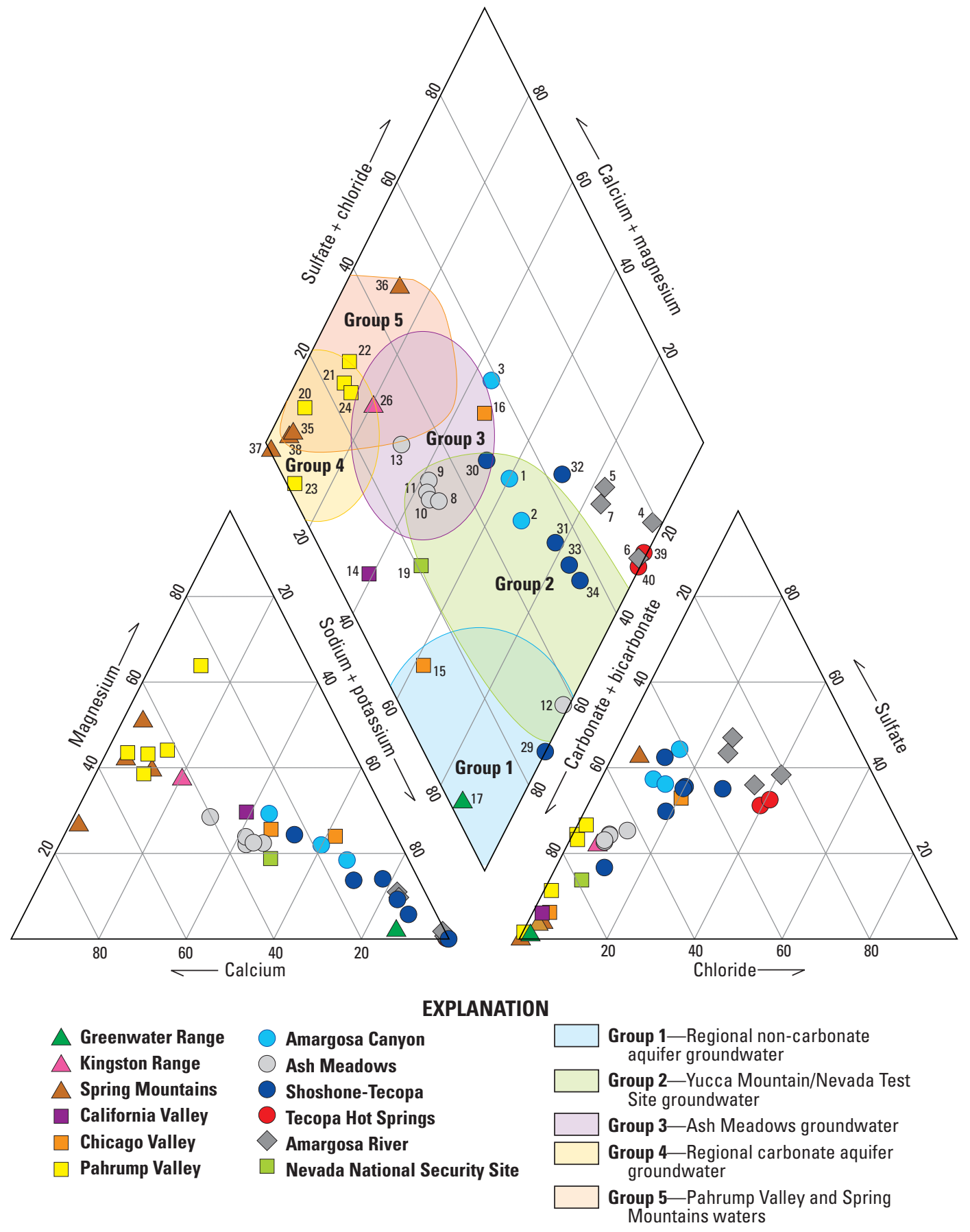

Figure 26. Representative water sample groups from the Lower Amargosa Valley and extra-basin contributing areas, California and Nevada. See table 10 for site reference number and site name. 


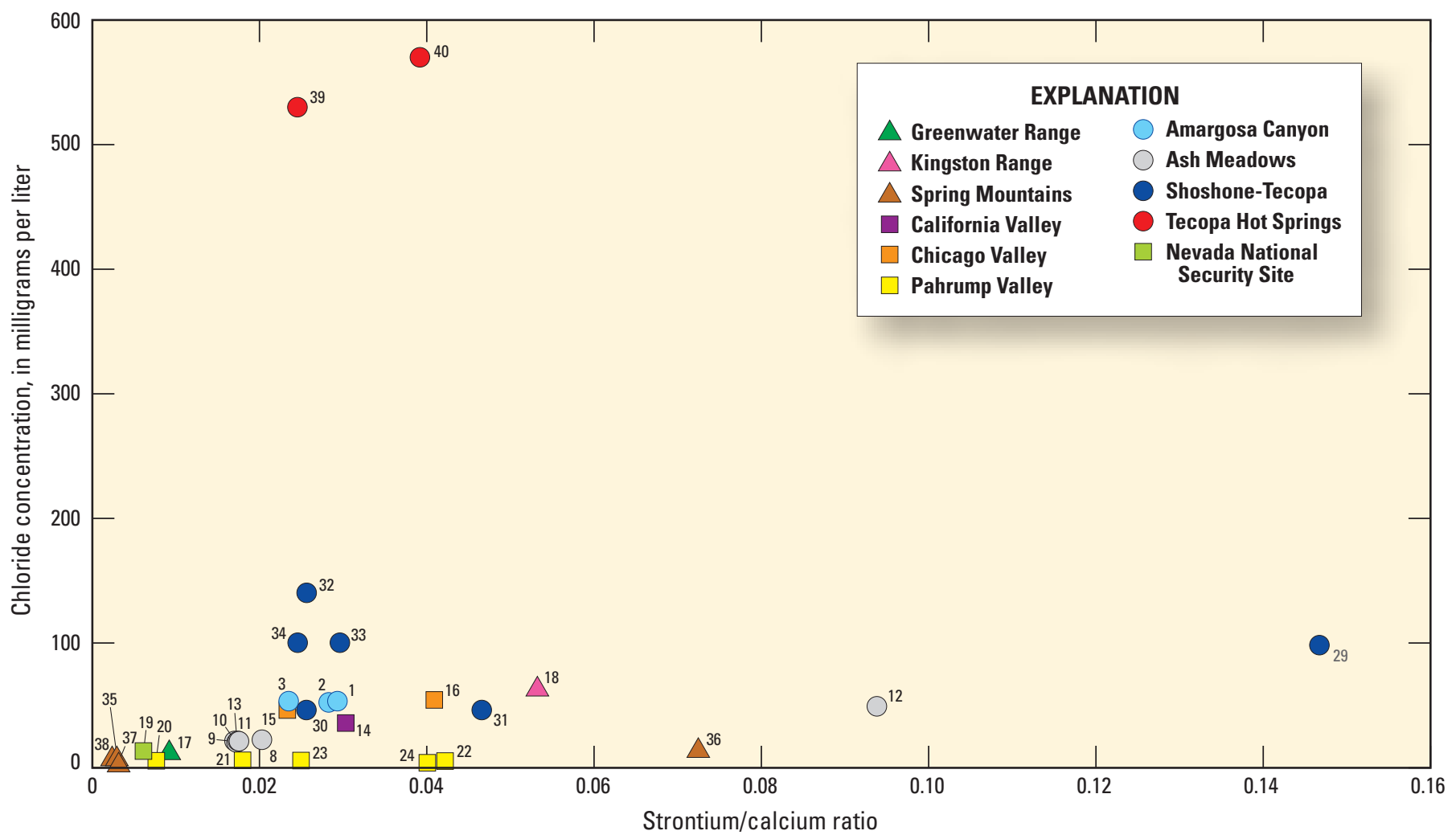

Figure 27. Chloride concentration versus strontium to calcium ratios in groundwater samples from the Lower Amargosa Valley and extra-basin contributing areas, California and Nevada. See table 10 for site reference number and site name.

Sodium to calcium $(\mathrm{Na} / \mathrm{Ca})$ ratios can also be used to assess how groundwater has evolved chemically along a flow path. Ratios can be influenced by ion exchange, mixing with different water types, or prior flow through carbonate rocks, as noted in the LAV and the extra-basin areas (Steinkampf and Werrell, 2001). A Na/Ca ratio of 0.4 indicates recently recharged waters associated with non-carbonate terrains that lie upgradient along the flow path, whereas $\mathrm{Na} / \mathrm{Ca}$ ratios greater than 10 indicate more evolved waters farther along a flow path (Steinkampf and Werrell, 2001). Figure 28 shows $\mathrm{Na} / \mathrm{Ca}$ ratios plotted against specific conductance, which is known to increase along a relative flow path, indicating an increase of solutes with increased water-rock interaction. Samples from the Spring Mountains (sites 35-38) and Pahrump Valley (sites 20-24) have relatively low specificconductance values (130 to $630 \mu \mathrm{S} / \mathrm{cm}$ ), low $\mathrm{Sr} / \mathrm{Ca}$ ratios (less than 0.02), and low $\mathrm{Na} / \mathrm{Ca}$ ratios (greater than 1.00), all indicating minimal geochemical evolution (figs. 25, 27, 28). As Na/Ca ratios increase in samples from Ash Meadows (sites 8-11, and 13), Chicago Valley (sites 15 and 16), the NNSS (site 19), and California Valley (site 14), so do conductance values, indicating greater groundwater evolution. The Shoshone-Tecopa sample group and Amargosa Canyon samples tend to have greater $\mathrm{Na} / \mathrm{Ca}$ ratios and greater sulfate concentrations and have "evolved" more than samples from surrounding areas. Few waters plot as more-evolved waters; Borax Spring (site 29) has a distinctly high $\mathrm{Na} / \mathrm{Ca}$ ratio $(2,300)$, as does water from the Hog Farm well in Ash Meadows (site 12;190), indicating that these sites were either affected by ion exchange or dissolved local evaporites, or have mixed with sodium-enriched waters. Tecopa Hot Springs samples also demonstrate a more-evolved $\mathrm{Na} / \mathrm{Ca}$ signature, with values of 200 and 370 . 


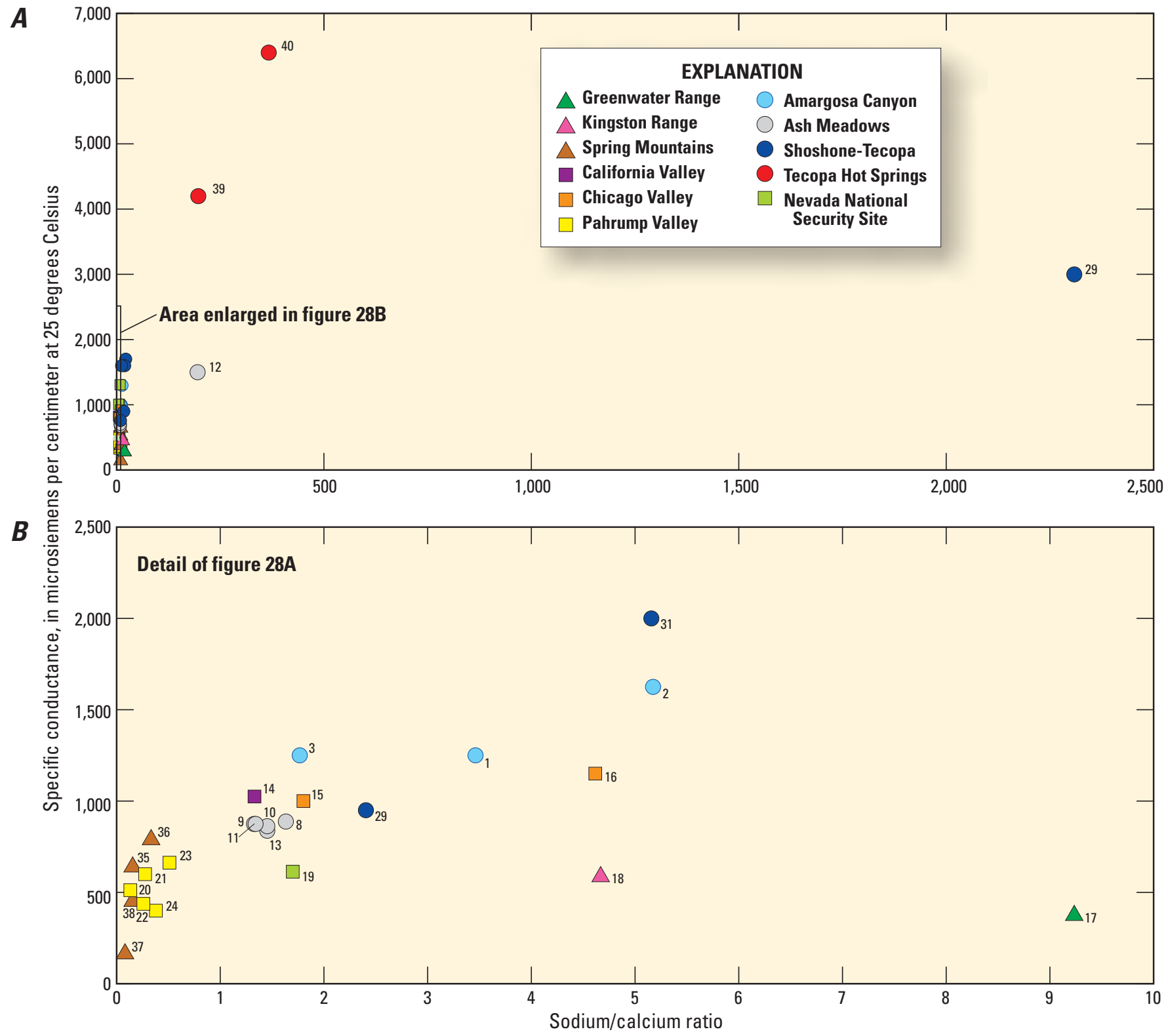

Figure 28. Specific conductance versus sodium-to-calcium ratios plotted at $A$, a normal scale and $B$, an enlarged scale, for groundwater samples from the Lower Amargosa Valley and extra-basin contributing areas, California and Nevada. See table 10 for site reference number and site name. 


\section{Trace Element Trends Among Groups}

Lithium, boron, and arsenic concentrations in groundwater samples can be used to help explain geochemical differences among groups of waters. Arsenic, boron, fluoride, and lithium tend to be naturally enhanced in geothermal waters compared to near-surface groundwaters (Goff and others, 1991). Lithium can be sourced from the dissolution of volcanic rocks (Hershey and others, 2010) or from lithiumbearing clay, such as in the Tecopa lake beds (Starkey and Blackmon, 1979), and tends to increase along flow paths (Hershey and others, 2010). Few lithium values are included in the data set for this study, but the largest lithium concentrations are in the Tecopa Hot Springs samples (sites 39 and 40), which likely indicate both geothermal inputs and interaction with the lithium-bearing Tecopa lake beds.

Arsenic concentrations vary throughout the study area, with many samples exceeding the U.S. Environmental Protection Agency's Maximum Contaminant Level (MCL) for arsenic (10 micrograms per liter $[\mu \mathrm{g} / \mathrm{L}])$ (U.S. Environmental Protection Agency, 2014). Arsenic concentrations in samples from Pahrump, Chicago, and California Valleys ranged from 0.50 to $59 \mu \mathrm{g} / \mathrm{L}$ (table 10). Ash Meadows samples contained arsenic concentrations between 10 and $120 \mu \mathrm{g} / \mathrm{L}$. Arsenic concentrations in the Shoshone-Tecopa sample group ranged from 13 to $110 \mu \mathrm{g} / \mathrm{L}$, with the exception of the sample from Borax Spring, which had an arsenic concentration of 1,600 $\mu \mathrm{g} / \mathrm{L}$. One sample from Amargosa Canyon had an arsenic concentration of $20 \mu \mathrm{g} / \mathrm{L}$; Tecopa Hot Springs samples had arsenic concentrations of 310 and $330 \mu \mathrm{g} / \mathrm{L}$. Aquatic life criteria also exist for surface water that are based on how much of a chemical can be present in water before it is likely to harm plant or animal life (https://www.epa. gov/wqc/aquatic-life-criteria-and-methods-toxics, accessed January 5, 2018). Amargosa River samples exceeded the freshwater aquatic life criterion maximum concentration for arsenic $(340 \mu \mathrm{g} / \mathrm{L})$ in all four samples and for chloride (860 mg/L) at sites 4 and 6 (https://www.epa.gov/wqc/ national-recommended-water-quality-criteria-aquatic-lifecriteria-table, accessed January 5, 2018). Chloride and arsenic concentrations at these levels may pose a threat to certain species. Surface-water chemistry may change with seasonality and precipitation, potentially rendering the chemistry of the Amargosa River more hospitable to sensitive species.

Generally, arsenic concentrations in samples evaluated as part of this study were positively correlated with concentrations of fluoride, lithium, and boron (fig. 29). Arsenic concentrations varied considerably among the ShoshoneTecopa groundwater samples, but concentrations of fluoride were similar (fig. 29A). In addition to having the largest arsenic concentration (1,600 $\mu \mathrm{g} / \mathrm{L})$, Borax Spring (site 29) also has a high $\mathrm{pH}$ (10) and the lowest dissolved oxygen value $(1.7 \mathrm{mg} / \mathrm{L})$ of all Shoshone-Tecopa samples (table 10). Arsenic mobility increases with increasing $\mathrm{pH}$ (Davisson, 2015) and reducing conditions. Other than Borax Spring, the Tecopa Hot Springs samples (sites 39 and 40) have similar and relatively high arsenic concentrations, as well as elevated fluoride concentrations (3.9 and $4.0 \mathrm{mg} / \mathrm{L}$ ), which indicates that these elements may be derived from geothermal interactions. The Shoshone-Tecopa sample group (sites 29-34), as well as samples from Amargosa Canyon (sites 1-3), tend to have arsenic concentrations greater than $10 \mu \mathrm{g} / \mathrm{L}$ and fluoride concentrations greater than $2.0 \mathrm{mg} / \mathrm{L}$. Samples from Ash Meadows (sites 8-13), the Spring Mountains (sites 35-38), and Pahrump Valley (sites 20-24) tend to have lower arsenic and fluoride concentrations.

Boron concentrations also vary throughout the LAV and extra-basin areas, and are generally much larger than boron concentrations in other parts of the country (Toccalino and others, 2010). The Shoshone-Tecopa sample group had boron concentrations of 1,400 to $130,000 \mu \mathrm{g} / \mathrm{L}$, with the largest boron concentration at Borax Spring (fig. 29). Amargosa Canyon samples had boron concentrations between 1,000 and $1,900 \mu \mathrm{g} / \mathrm{L}$, whereas Tecopa Hot Springs samples had larger boron concentrations of 9,200 and $11,000 \mu \mathrm{g} / \mathrm{L}$. Boron is likely sourced from the Tecopa lake beds which contain borate minerals (Larsen and others, 2001). Boron concentrations were plotted against $\mathrm{Sr} / \mathrm{Ca}$ ratios (fig. 30) to determine which sites may have interacted with evaporites in the Tecopa lake beds. Borax Spring (site 29) had the largest concentration of boron $(130,000 \mu \mathrm{g} / \mathrm{L})$ and the highest $\mathrm{Sr} / \mathrm{Ca}$ ratio (0.15), indicating borate mineral dissolution from the Tecopa lake beds (fig. 30). Similar Sr/Ca ratios were noted among the Tecopa Hot Springs samples (sites 39 and 40), and remaining samples from the Shoshone-Tecopa sample group (sites 29, 31-34) all showed relatively high boron concentrations exceeding 1,400 $\mu \mathrm{g} / \mathrm{L}$ (fig. 30); however, it is possible that some of the boron in the hot springs is from geothermal sources. Samples obtained from Amargosa Canyon (sites 1-3) and Chicago Valley (site 15) also showed somewhat elevated concentrations of boron and slightly higher $\mathrm{Sr} / \mathrm{Ca}$ ratios, as compared to most of the samples from the Spring Mountains (sites 35, 37, 38), Ash Meadows (sites 8-11 and 13), and Pahrump Valley (site 20). Lithium concentrations ranged from 4.9 to $220 \mu \mathrm{g} / \mathrm{L}$, with the smallest value in Chicago Valley and the largest value in the Tecopa Hot Springs; elevated lithium concentrations can indicate geothermal interaction. Uranium concentrations did not vary significantly throughout the study area and were less than $10 \mu \mathrm{g} / \mathrm{L}$, with no detectable pattern among groups. 

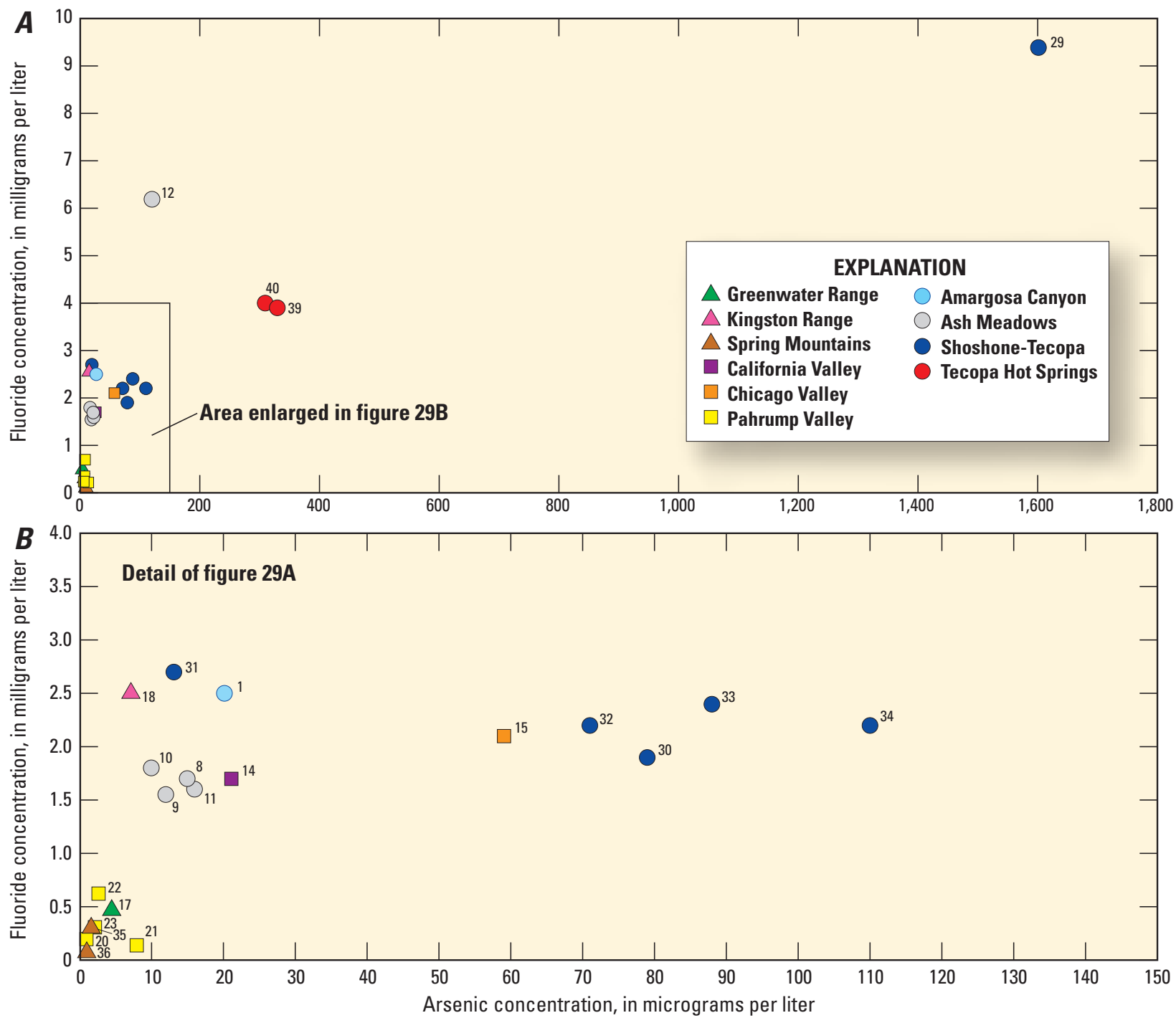

Figure 29. Fluoride, lithium, and boron concentrations versus arsenic concentration plotted at $A, C$, and $E$, a normal scale, and $B, D$, and $F$, an enlarged scale, for groundwater samples from the Lower Amargosa Valley and extra-basin contributing areas, California and Nevada. See table 10 for site reference number and site name. 

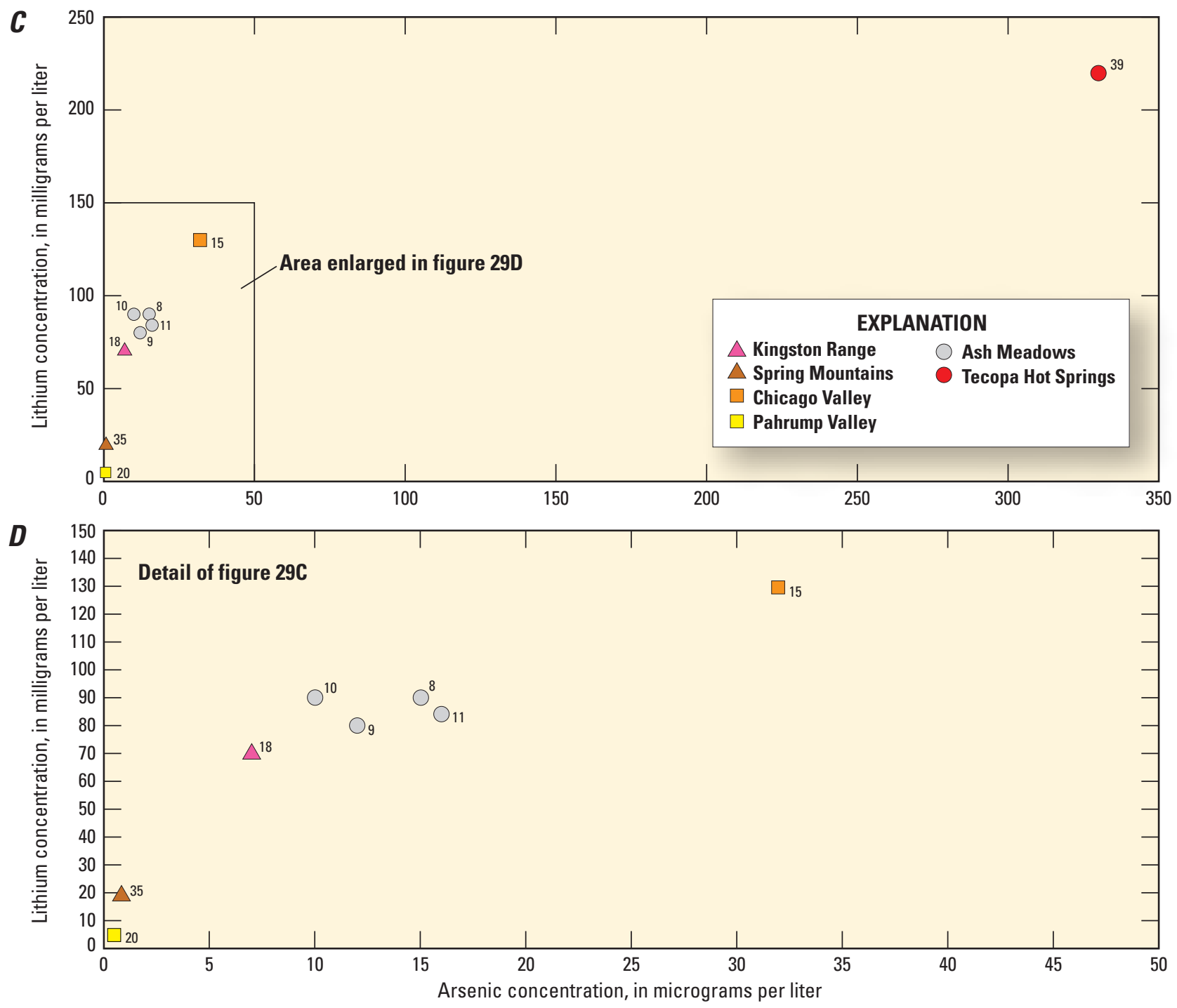

Figure 29. - Continued 

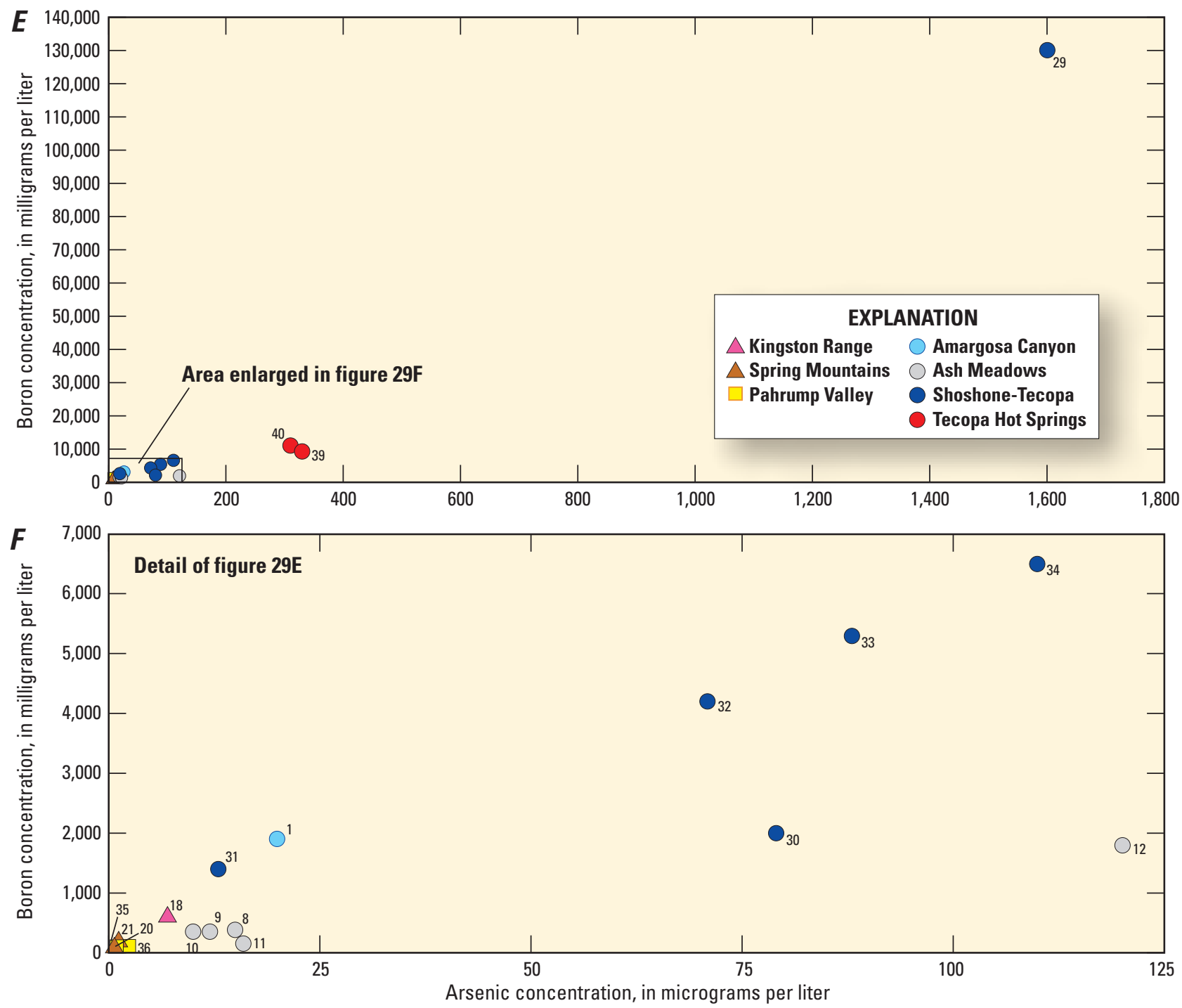

Figure 29. - Continued 


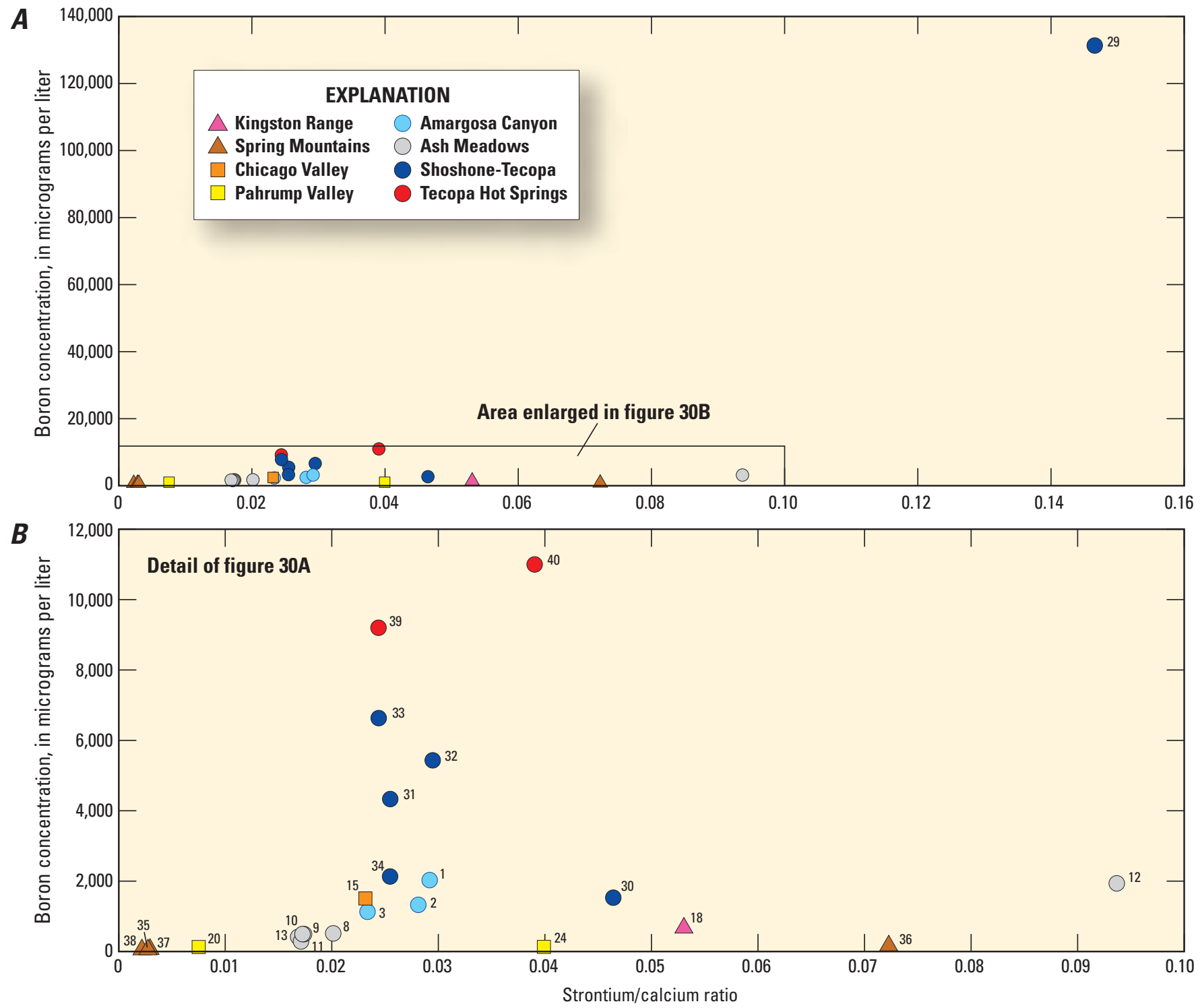

Figure 30. Boron concentration versus strontium to calcium ratios plotted at $A$, a normal scale, and $B$, an enlarged scale, for groundwater samples from the Lower Amargosa Valley and extra-basin contributing areas, California and Nevada. See table 10 for site reference number and site name. 


\section{Amargosa River Chemistry}

The few surface-water samples available for hydrochemical analysis in the LAV (table 10, sites 7-10) provide insight into the interaction between the surface water and groundwater. Specific conductance and solute concentrations increase in Amargosa River water as it flows downstream from Shoshone Spring toward the Amargosa Canyon, with specific conductance increasing from 3,300 to $13,000 \mu \mathrm{S} / \mathrm{cm}$. Evapoconcentration, flow through evaporite deposits of the Tecopa lake beds, and introduction of high conductance spring water are likely the cause of the high solute concentrations and unique isotopic signatures observed in water samples collected from the river. The stable isotopes of $\delta^{18} \mathrm{O}$ and $\delta^{2} \mathrm{H}$ from Amargosa River samples plot below and to the right of the LMWL (fig. 24); a linear regression of these river samples has a slope of 4.8 , which is indicative of evaporation (Clark and Fritz, 1997). The surface-water samples plot between the Shoshone-Tecopa sample group and Tecopa Hot Springs samples on the trilinear diagram (fig. 26), supporting the idea that high conductance waters from these springs are likely contributing to river chemistry.

The Amargosa River flows over the Tecopa lake bed deposits and acquires a chemical signature that reflects dissolution of those deposits. The Amargosa River samples (sites 4-6) also have elevated arsenic concentrations (170$1,000 \mu \mathrm{g} / \mathrm{L}$ ), indicating dissolution of minerals in the Tecopa lake beds or evaporative effects on groundwater discharged to the river. Surface-water samples also have a chemical signature similar to that in Shoshone-Tecopa groundwater samples, with high boron concentrations $(7,900-20,000 \mu \mathrm{g} / \mathrm{L})$. In addition, concentrations of many trace elements and the major ions are much higher in river samples than in groundwater samples due to interaction with evaporite deposits and evaporation.

\section{Geochemical Modeling}

Seven potential groundwater flow paths in the study area were evaluated with respect to their geochemical evolution and the most realistic models presented (fig. 31). Initial sources of water (Spring Mountains, Ash Meadows, and the local basin-fill aquifer) and selected final discharge points within the LAV (Shoshone, Amargosa Canyon Spring 4, and Wild Bath Spring) were considered to be along potential flow paths (table 13). Some flow paths allowed for the mixing of two initial waters; the resulting models provide the percentage contribution from each source water (table 13). Many of the chemical reactions evaluated along the possible flow paths are similar to those in other geochemical modeling applications in nearby areas (Thomas and others, 2002; Bushman and others, 2010; Marshall and others, 2012). The number of phases included in each model is constrained by the number of elements in the model. Feasible geochemical reactions that can explain the changes in water chemistry along proposed flow paths include dissolution/precipitation of anhydrite, calciummontmorillonite, gypsum, fluorite, kaolinite, and amorphous silica; dissolution of illite; and exchange of calcium for sodium on clays or zeolites.

The results of composited water samples were used to represent the water chemistry from Ash Meadows, the Spring Mountains, Pahrump Valley, and local recharge; the individual well or spring was used in modeling to represent the chemistry of the region. Ash Meadows is not considered a primary recharge area; water at that location lies along an intermediate flow path, upgradient from the LAV. For the purposes of this modeling effort, however, it is considered as an initial water (table 13; fig. 31). Flow paths from Ash Meadows (represented by the Five Springs well, site 11) to Shoshone Spring (site 32) and Amargosa Canyon Spring 4 (site 2) (fig. 31, flow paths A and D) indicate that waters from these springs may initially flow through the Ash Meadows area. A Spring Mountains sample (represented by Peak Spring, site 37) was used as an initial water for flow paths B and E to Shoshone Spring (site 32) and Wild Bath Spring (site 34), respectively, with results indicating that water from the Spring Mountains could be the source of water to these downgradient springs. Flow path B included four possible feasible models (table 13); it is likely that a realistic simulation of the chemical reactions along this flow path would involve precipitation of calcite given the long residence time and its oversaturation at both sites (table 12).

A mixed-source model (fig. 31, flow path C) indicated that water from the Spring Mountains composes approximately 61 percent of the water at Shoshone Spring (site 32). Water from Pahrump Valley could provide the additional 39 percent of the water at Shoshone Spring.

In another model (fig. 31, flow path D), mixing waters from Ash Meadows and the local alluvial/basin-fill aquifer could result in the water chemistry at Amargosa Canyon Spring 4 (site 2). Multiple mixing scenarios are chemically feasible for this flow path where water from either Ash Meadows or the local aquifer could evolve to the water discharging at Amargosa Canyon Spring 4 (site 2), although the model that accounts for the dissolution of halite and illite is most representative of geochemical conditions at the site (table 13). A mix of water (fig. 31, flow path F) from Borehole Spring (site 39) and the local alluvial/basin-fill aquifer was simulated to produce the water chemistry at Wild Bath Spring (site 34) and to simulate mixing of thermal water from Tecopa Hot Springs (site 40) and local alluvial aquifer water. Water from Borehole Spring was simulated to provide up to 50 percent of the water at Wild Bath Spring, and water from the local alluvial/basin-fill aquifer could provide between 50 and 100 percent. The geochemical models presented here are all chemically feasible, but not necessarily feasible with respect to the hydrology and/or geology, and models could be better calibrated with a more complete knowledge of the local mineralogy at depth. 


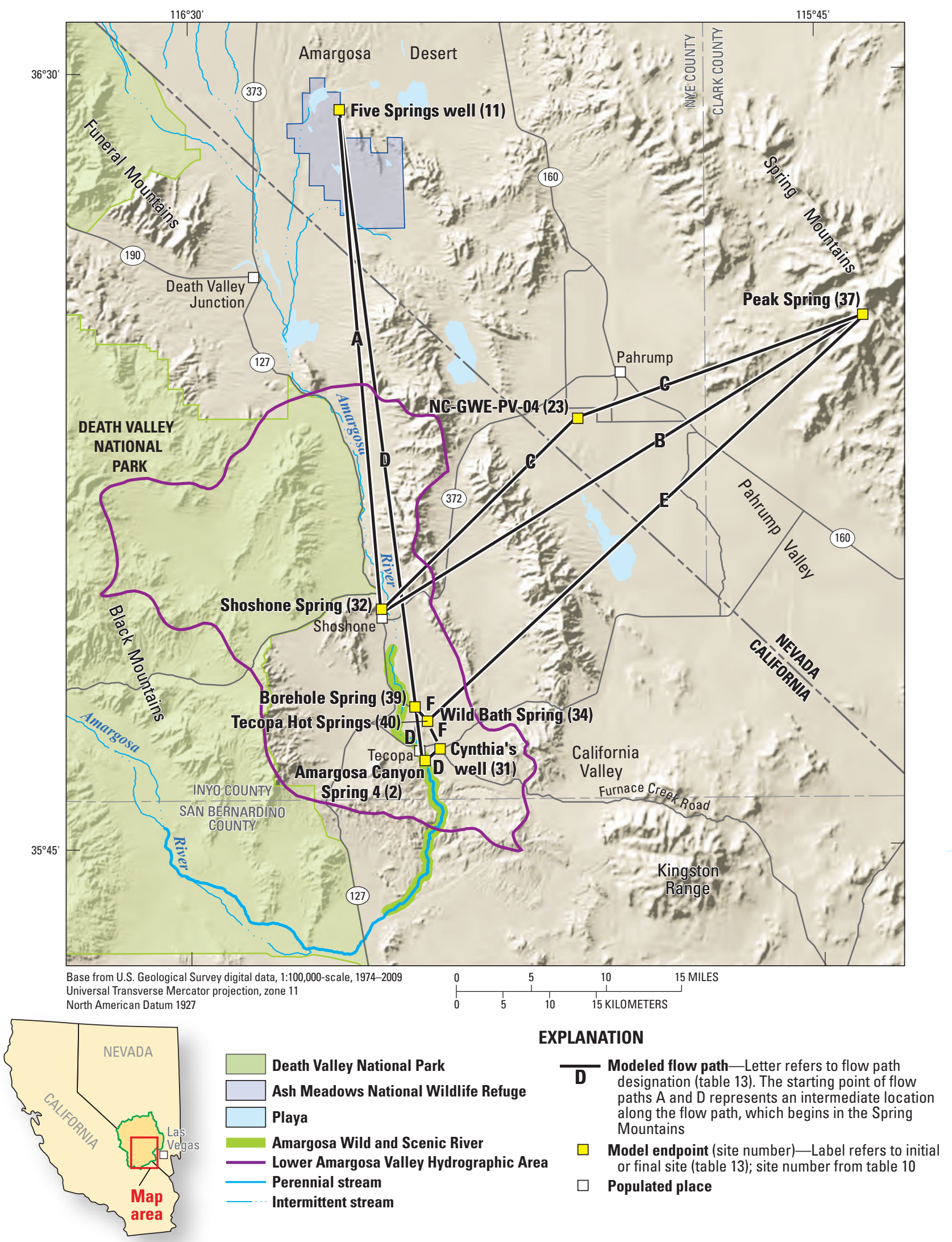

Figure 31. Feasible modeled flow paths to the Lower Amargosa Valley from extra-basin contributing areas, California and Nevada. 
Table 13. Geochemical modeling results for attempted flow paths to the Lower Amargosa Valley from extra-basin contributing areas, California and Nevada.

[Percent solution indicates the amount of initial solution(s) required to produce the final solution. Solutions are not repeated twice if modeled during mixing. Most likely models in bold and listed first. Positive and negative phase mass transfers indicate dissolution and precipitation, respectively. Abbreviation: - , phase not required by model]

\begin{tabular}{|c|c|c|c|c|c|c|c|c|c|c|c|c|c|}
\hline \multicolumn{4}{|c|}{ Solution ${ }^{1}$} & \multicolumn{10}{|c|}{ Phase mass transfer (millimoles per kilogram of water) } \\
\hline Initial site ${ }^{2}$ & $\begin{array}{l}\text { Percent } \\
\text { solution }\end{array}$ & Final site & Anhydrite & $\begin{array}{c}\text { Calcium- } \\
\text { Montmorillonite }\end{array}$ & Calcite & Gypsum & Halite & Illite & Fluorite & Kaolinite & $\begin{array}{l}\text { Amorphous } \\
\text { silicon dioxide }\end{array}$ & $\begin{array}{c}\text { Calcium } \\
\text { exchange }\end{array}$ & $\begin{array}{c}\text { Sodium } \\
\text { exchange }\end{array}$ \\
\hline \multicolumn{14}{|c|}{ Flow path $A-$ Two successful models } \\
\hline Five Springs well (AM-2) & 100 & Shoshone Spring & - & 0.08004 & - & 1.574 & 3.389 & 0.8109 & 0.00158 & - & $\mathbf{0 . 0 3 8 3}$ & -1.632 & 3.264 \\
\hline Five Springs well (AM-2) & 100 & Shoshone Spring & 1.574 & -0.8004 & - & - & 3.388 & 0.08108 & 0.00158 & - & 0.0383 & -1.632 & 3.264 \\
\hline \multicolumn{14}{|c|}{ Flow path $B-$ Four successful models } \\
\hline Peak Spring & 100 & Shoshone Spring & 374.4 & -1.155 & - & -374.4 & 3.923 & 1.170 & -5.487 & - & 0.6497 & -2.673 & 5.364 \\
\hline Peak Spring & 100 & Shoshone Spring & 374.4 & - & 0.5691 & -374.4 & 3.923 & 1.170 & 0.0549 & 7.035 & 8.741 & -2.469 & 4.939 \\
\hline Peak Spring & 100 & Shoshone Spring & 374.4 & -1.155 & - & -374.4 & 3.923 & 1.170 & 0.0549 & - & 0.6497 & -2.673 & 5.346 \\
\hline Peak Spring & 100 & Shoshone Spring & 374.4 & -1.155 & 0.0425 & -374.4 & 3.923 & 1.170 & 0.0549 & - & 0.6497 & -2.716 & 5.431 \\
\hline \multicolumn{14}{|c|}{ Flow path $\mathrm{C}$ - Two successful models } \\
\hline $\begin{array}{l}\text { Peak Spring, } \\
\text { NC-GWE-PV-04 }\end{array}$ & 61,39 & Shoshone Spring & 2.276 & -1.231 & -2.411 & - & 3.914 & 1.155 & 0.05081 & 13.01 & 15.51 & -2.411 & 4.821 \\
\hline $\begin{array}{l}\text { Peak Spring, } \\
\text { NC-GWE-PV-04 }\end{array}$ & 61,39 & Shoshone Spring & - & 12.31 & 2.55 & 2.276 & 3.914 & 1.155 & 0.05081 & 13.01 & 15.51 & -2.411 & 4.821 \\
\hline \multicolumn{14}{|c|}{ Flow path D - Three successful models } \\
\hline $\begin{array}{l}\text { Five Springs well (AM-2), } \\
\text { Cynthia's well }\end{array}$ & 5,95 & $\begin{array}{l}\text { Amargosa Canyon } \\
\text { Spring } 4\end{array}$ & 123.9 & -0.5492 & - & -123.9 & - & - & - & 0.6399 & - & - & - \\
\hline $\begin{array}{l}\text { Five Springs well (AM-2), } \\
\text { Cynthia's well }\end{array}$ & 0,100 & $\begin{array}{l}\text { Amargosa Canyon } \\
\text { Spring } 4\end{array}$ & 576.9 & -0.6331 & - & 577 & - & - & - & 0.7376 & - & 1.051 & -2.102 \\
\hline $\begin{array}{l}\text { Five Springs well (AM-2), } \\
\text { Cynthia's well }\end{array}$ & 100,0 & $\begin{array}{l}\text { Amargosa Canyon } \\
\text { Spring } 4\end{array}$ & 956.8 & -0.5433 & - & -956.6 & 0.709 & 0.5504 & 0.02237 & - & - & -1.823 & 3.646 \\
\hline \multicolumn{14}{|c|}{ Flow path $E-O$ ne successful model } \\
\hline Peak Spring & 100 & Wild Bath Spring & 141.6 & -19.68 & 5.316 & 141.7 & 2.818 & 1.232 & 0.05732 & 21.51 & 26.46 & -4.462 & 8.924 \\
\hline \multicolumn{14}{|c|}{ Flow path $\mathrm{F}$ - Three successful models } \\
\hline $\begin{array}{l}\text { Borehole Spring, } \\
\text { Cynthia's well }\end{array}$ & $\mathbf{0 , 1 0 0}$ & Wild Bath Spring & -219.1 & -18.73 & 5.162 & 219.1 & 2.551 & 1.085 & 0.04302 & 20.58 & 25.17 & -3.739 & 7.478 \\
\hline $\begin{array}{l}\text { Borehole Spring, } \\
\text { Cynthia's well }\end{array}$ & 50,50 & Wild Bath Spring & -897.1 & -0.5924 & -718 & 897.1 & -2.737 & 0.6001 & - & - & 0.7803 & - & - \\
\hline $\begin{array}{l}\text { Borehole Spring, } \\
\text { Cynthia's well }\end{array}$ & 18,82 & Wild Bath Spring & -960.5 & -0.4983 & 1.264 & 960.6 & - & 0.5048 & - & - & 0.8573 & -1.197 & 2.394 \\
\hline
\end{tabular}

Cynthia's well

${ }^{1}$ For solutions or mixtures of solutions that were evaporated: micromoles/kilogram of water where kilograms of water $=$ sum of percent of initial solution(s)/100.

${ }^{2}$ Initial sites represent recharge areas or intermediate points along a flow path. Five Springs (AM-2) is in the Ash Meadows intermediate area; Peak Spring is in the Springs Mountains recharge area; NC-GWPV-04 is in the Pahrump Valley intermediate area; Cynthia's well is in the Shoshone-Tecopa intermediate area; and Borehole Spring is in the Shoshone-Tecopa intermediate area. 
Models presented in table 13 only represent some of the possible geochemical scenarios that may explain the chemical evolution of water from extra-basin recharge areas to the LAV. However, these models can be used to verify whether some of the flow paths between initial/intermediate and final areas that have been previously postulated can be explained using the available water chemistry and local geology. Modeled flow paths indicate that the dissolution of solutes in the LAV is an important geochemical process that leads to the unique chemical signatures of LAV samples. The conceptual flow paths suggest that interbasin flow sourced in the Spring
Mountains moves southwest through the intervening Nopah and Resting Spring Ranges to the springs in the Tecopa basin and also moves from an intermediate location in Ash Meadows in the Amargosa Desert south into the Tecopa basin (fig. 31; table 14). A significant component of local recharge is not required to explain the geochemistry at these springs. Viable geochemical models include the dissolution of many evaporite minerals and re-precipitation of some minerals at certain locations. Cation exchange appears to be an important process due to clay minerals in the Tecopa lake beds.

Table 14. Water budget components for the Lower Amargosa Valley, California.

[acre-ft, acre-foot; $\mathrm{m}^{3}$, cubic meter]

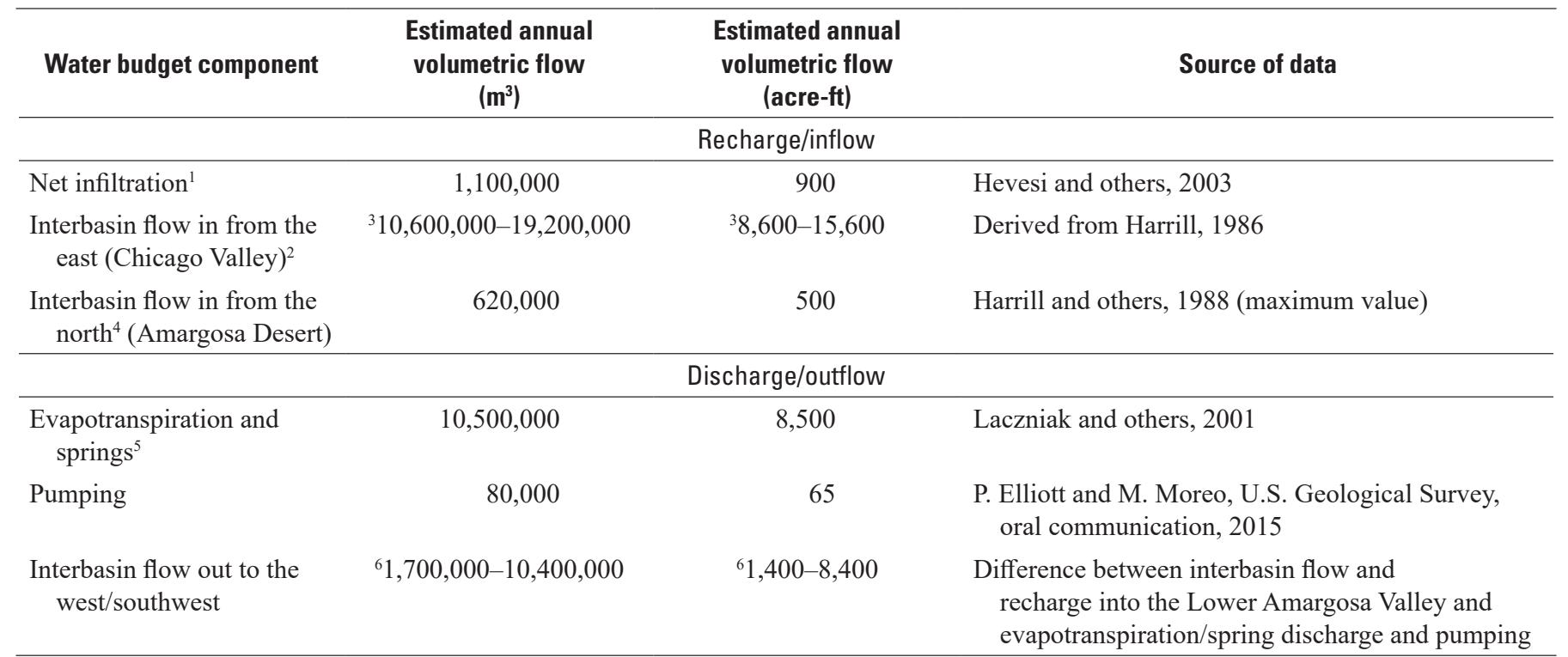

\footnotetext{
${ }^{1}$ Recharge from the direct infiltration of precipitation within the Lower Amargosa Valley.

${ }^{2}$ Assumed to occur through the carbonate-rock aquifer.

${ }^{3}$ The interbasin inflow component of recharge to Lower Amargosa Valley is derived by subtracting pre-development estimates of annual groundwater discharge from Pahrump Valley (10,000 to 13,000 acre-feet) reported by Harrill (1986) and the estimate of annual groundwater discharge from Chicago Valley (430 acre-feet) reported by Laczniak and others (2001) from the range of annual recharge to Pahrump Valley (22,000 to 26,000 acre-feet) reported by Harrill (1986). Because some of these values represent pre-development conditions, the budget is not necessarily representative of current (2018) conditions, which may be affected by upgradient groundwater development.

${ }^{4}$ Assumed to occur through the alluvial/basin-fill aquifer.

${ }^{5}$ This is the sum of groundwater discharge by evapotranspiration estimates for the Shoshone and Tecopa areas reported by Laczniak and others (2001).

${ }^{6}$ The interbasin outflow from the Lower Amargosa Valley is likely closer to the middle of this range due to the relatively impermeable volcanic bedrock west and southwest of the hydrographic basin. It is possible that southwestward interbasin flow through fractured low-permeability rocks contributes to discharge from Saratoga Springs (3,040,000 cubic meters per year or 2,500 acre-feet per year; Faunt, Blainey, and others, 2010). Because of uncertainty in the budget estimates used to derive the estimate of interbasin flow, the lower value may be as low as zero.
} 


\section{Hydrogeologic Conceptual Model}

Previously published conceptualizations of groundwater flow in the southern Death Valley subregion have recognized that insufficient recharge exists within the subregion and the LAV to support the observed volumes of spring discharge and perennial streamflows (Mifflin, 1988; Harrill and others, 1988; Harrill and Prudic, 1998; Faunt, D'Agnese, and O'Brien, 2010). Previous studies have proposed two main contributions of groundwater from outside the LAV: (1) southwestward flow from the Spring Mountains across Pahrump Valley to the Nopah Range and California Valley (Malmberg, 1967; Larsen and others, 2001; Faunt, D'Agnese, and O'Brien, 2010), or (2) southward flow from the Amargosa Desert and Ash Meadows, either moving north-to-south along the course of the Amargosa River or as southward-moving water entering the subregion from the southern part of the Amargosa Desert (Miner and others, 2007; Zdon and others, 2015). Most previous conceptualizations emphasize the importance of recharge from remote uplands, primarily the Spring Mountains, and regional interbasin flow (Larsen and others, 2001; Faunt, D'Agnese, and O'Brien, 2010; Zdon and others, 2015), although the potential importance of a local recharge component is emphasized in some studies (Miner and others, 2007; Zdon and others, 2015). Some previous studies have attempted to conceptualize the local controls on spring discharge within the LAV, with normal faults beneath the Amargosa River south of Eagle Mountain forcing groundwater upward to the surface or a shallow (less than $6 \mathrm{mi}$ deep) intrusive body influencing the flow of groundwater (Steinkampf and Werrell, 2001). All of the previous studies present an incomplete conceptualization, relying on either small numbers of sampled springs, being based on limited localized data, or, based on regional waterbudget considerations without specific reference to data from the LAV.

\section{Carbonate-Rock Aquifer Signature in Groundwater}

Regional groundwater that comes into contact primarily with carbonate rock will reflect this in its dissolved major-ion chemical signature, typically having increased concentrations of calcium, magnesium, and bicarbonate. However, it is likely that groundwater from the carbonate-rock aquifer discharging in the Shoshone-Tecopa area has moved through aquifer materials containing evaporite minerals on its way to the surface that impart a unique chemical signature to the water.

Discharge from Chappo Spring (site 30), Shoshone Spring (site 32), and springs in the Amargosa Canyon (sites 1-3) have a similar water type to Ash Meadows samples (fig. 26). Chappo Spring (site 30), which has a sodium-magnesium-calcium-bicarbonate-sulfate type water, discharges directly from Paleozoic carbonate rocks (pl. 1). Springs in the Amargosa Canyon (sites 1-3) discharge from the eastern wall of the canyon, and appear to represent water that has not significantly interacted with evaporites (pl. 1) as would be indicated by elevated sodium concentrations. Shoshone-Tecopa water samples do not cleanly plot in groups identified in previous studies; many of these groups overlap and it is difficult to identify the source of Shoshone-Tecopa water solely based on water type. Recharge from the Spring Mountains andother surrounding mountain ranges could account for the isotopic values in water from the TecopaShoshone region (Steinkampf and Werrell, 2001; Davisson, 2015). These waters likely originate from regional flow through the carbonate-rock aquifer in Chicago Valley or other mostly carbonate-rock aquifer sources.

\section{Tecopa Lake Beds and China Ranch Beds}

In the Tecopa basin, Cenozoic alkaline-lake deposits that make up the Tecopa lake beds are as thick as $560 \mathrm{ft}$ (Louie and others, 2001); the extent of the Tecopa lake beds is shown on figure 5. These lake beds confine groundwater in the center of the basin (Larsen and others, 2001) and contain soluble minerals that can locally influence groundwater chemistry. Mineralogy of the Tecopa lake beds varies throughout the basin. Minerals identified by previous studies include gaylussite, authigenic potassium feldspar, illite, salesite, opal, quartz, calcite, halite, dolomite, siderite, aragonite, and gypsum (Starkey and Blackmon, 1979; Larsen, 2008).

Of the Shoshone-Tecopa sample group (sites 29-34), three springs discharge from exposed Tecopa lake bed deposits, which influence the chemistry of the springs (table 10; pl. 1). Groundwater from these springs likely migrates through the evaporite deposits before discharging, influencing water chemistry and increasing specific conductance (dissolved-solids concentration). Discharge from Thom Spring is likely sourced from a combination of alluvial and carbonate-rock aquifer water or thermal water and water from alluvial aquifers that migrates through the Tecopa lake beds, resulting in higher conductance values and elevated boron concentrations. Wild Bath Spring (site 34) may be sourced from a mixture of thermal water (as indicated by elevated water temperatures) and groundwater from alluvial aquifers or from a confined aquifer and discharges upward through the lake bed deposits, also resulting in a chemical signature that is indicative of interaction with evaporites. Boron concentrations for Thom Spring and Wild Bath Spring plot between other regional groundwater samples and those from the Tecopa Hot Springs (fig. 30, sites 39 and 40), indicating similar geologic influences. 
Shoshone Spring (site 32) is not located on the Tecopa lake beds, but may interact with these deposits at depth or near the point of discharge. Spring temperature (about $34^{\circ} \mathrm{C}$ ) and major-ion concentrations similar to those in water from Ash Meadows (sites 8-13) indicate Shoshone Spring is likely sourced from the regional carbonate-rock aquifer. Other solutes such as sodium, potassium, chloride, and sulfate are higher at Shoshone Spring than at sites in Ash Meadows, indicating further dissolution along the flow path between Ash Meadows (sites 8-13) and Shoshone Spring. The Tecopa lake beds exist near the spring (toward the valley axis), and may act as a confining bed, allowing groundwater to discharge at Shoshone Spring.

Borehole Spring (site 39) and Tecopa Hot Springs (site 40) of the Tecopa Hot Springs group also discharge from Tecopa lake bed deposits. The thermal groundwater is most likely sourced from confined water in the China Ranch beds, with the overlying Tecopa lake beds acting as a confining unit approximately $350 \mathrm{ft}$ below land surface, as indicated on the Stauffer well record (Rhodes, 1969). As this water moves upward and past the confining unit, it encounters hundreds of feet of low-permeability Tecopa lake beds. The thermal temperatures of these waters increase the solubility of most evaporite minerals, enhancing their dissolution. The unique chemistry of these two hot springs, characterized by their high specific-conductance values, high concentrations of sodium, arsenic, and chloride, and low concentrations of calcium and magnesium, indicates the dissolution of evaporites, similar to the chemistry of water from Borax Spring. Saturation indices in water from these two sites show that calcite is at equilibrium and may have precipitated out of solution, whereas geochemical models support the precipitation of dolomite and calcium montmorillonite, along with a considerable amount of cation exchange.

\section{Hydrogeologic Controls}

In order to assess the feasibility of the geochemical flow paths depicted on figure 31 and in table 13, the hydrogeology was evaluated to further refine these flow paths. Figure 32 summarizes the potential flow paths in the subregional flow system based on stratigraphic and structural controls. Using the inferred subsurface hydrogeology, three potential groundwater pathways are proposed: (1) westward subsurface flow from the Spring Mountains beneath Pahrump Valley to the northern half of the Nopah Range through the carbonaterock aquifer, (2) southward flow from the Amargosa Desert in Cenozoic basin-fill deposits and shallow subsurface flow in the Amargosa River channel and associated alluvial deposits, and (3) southwestward flow from the Spring Mountains beneath Pahrump Valley to California Valley through the carbonaterock aquifer.

The majority of water moving into the Tecopa basin likely moves westward along an interbasin flow pathway through the carbonate-rock aquifer from Pahrump Valley through the northern half of the Nopah Range into the area where the carbonate-rock aquifer presumably lies beneath the Tecopa basin and Chicago Valley, and the intervening southern part of the Resting Spring Range. To the east of the Tecopa basin, Chappo Spring issues from the base of the carbonaterock aquifer at the topographically lowest exposure of this bed on the west side of the Resting Spring Range. Water flowing from Pahrump Valley likely intersects the base of the carbonate-rock aquifer in this part of the Resting Spring Range and discharges to the surface along fractures within the carbonate rock. In the northern Resting Spring Range, the base of the carbonate-rock aquifer is not exposed and water flows from Pahrump Valley into the Tecopa basin. Shoshone Spring issues from an east-tilted faulted carbonate-rock block on the west side of the basin. Geophysical studies by Louie and others (2001) reveal listric, moderately west-dipping faults at the base of the Resting Spring Range that downdrop the carbonate-rock section into the basin. There may be a highly faulted series of back-rotated carbonate-rock blocks beneath the Tecopa lake beds at the northern end of the basin, similar to the exposed Dublin Hills. These highly faulted blocks may create a permeable pathway in the carbonaterock aquifer, allowing water to flow beneath the Tecopa basin from the Resting Spring Range to the seeps and springs on the west side of the basin, including Shoshone and Borax Springs. The maximum possible subsurface distribution of buried carbonate rock is confined to the east by siliciclastic rocks in the southern half of the Nopah Range, to the south by the Sheephead fault, where the only consolidated bedrock to the south of the fault is Proterozoic siliciclastic rock, and to the west by the Dublin Hills where the outcrop of limestone near Shoshone Spring is the westernmost exposure of carbonate rock.

The southward flow path from the Amargosa Desert north of Eagle Mountain is largely based on water balances (Harrill and others, 1988). Groundwater likely flows through the Cenozoic basin fill and volcanic rocks, along with minor surface flow in the Amargosa River and related subsurface flow through the Amargosa River channel alluvium. Harrill and others (1988) estimated that groundwater interbasin flow from the Amargosa Desert to the LAV was no more than 500 acre-ft/yr. Recent geophysical surveys (Blakely and Ponce, 2001) show that there is sufficient thickness of basinfill deposits to allow some volume of groundwater to flow from the Amargosa Desert to the LAV. The thick section of basin fill northwest of Eagle Mountain abuts against fractured volcanic rocks, potentially providing an interbasin flow pathway. However, geologic conditions are not favorable for a significant amount of groundwater flow to enter the Tecopa basin from the southern Amargosa Desert and the area north of Eagle Mountain through the carbonate-rock aquifer. The base of the carbonate-rock aquifer is exposed on the southwestern flank of Eagle Mountain, so no likely flow path exists through the carbonate rock in this area. 


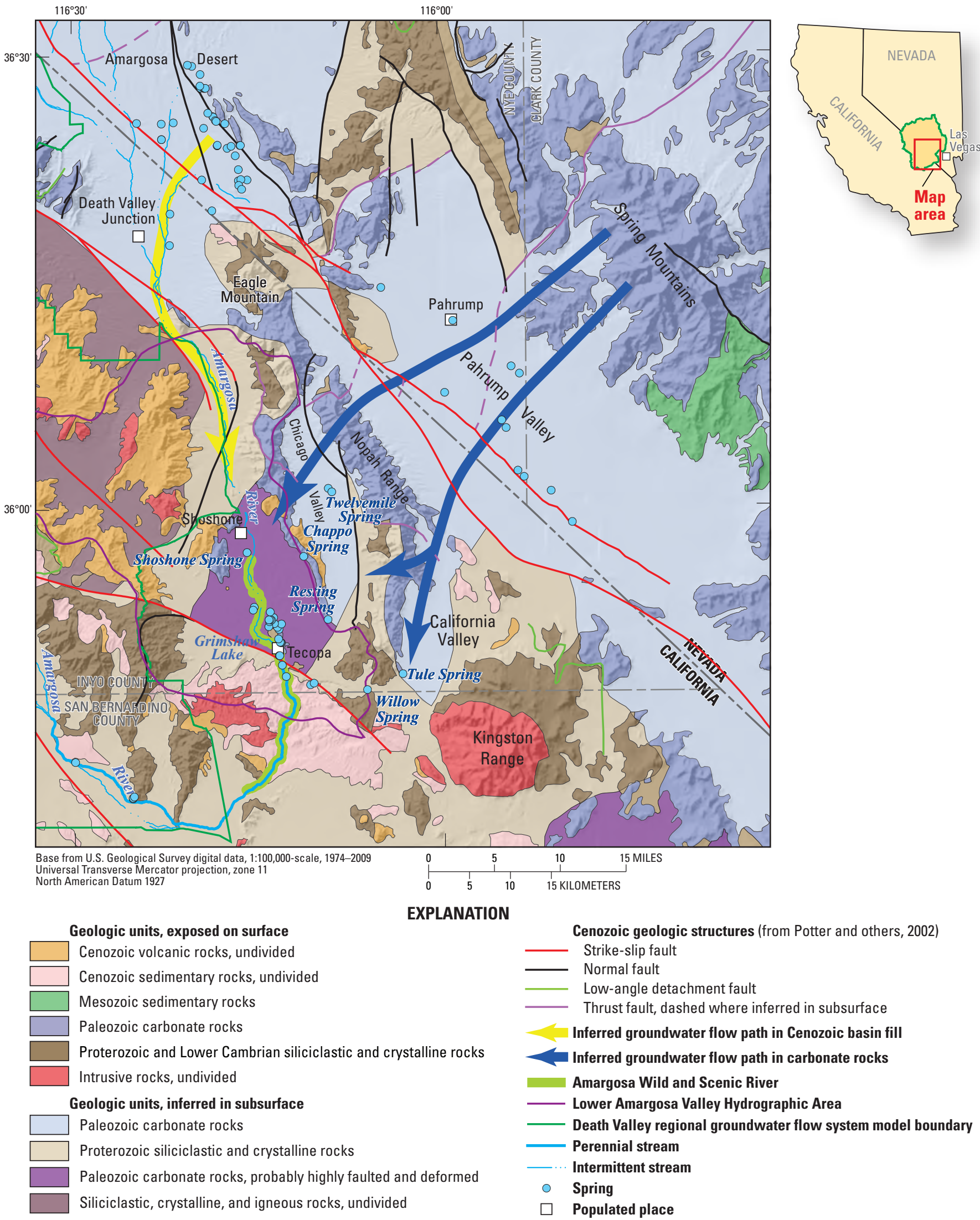

Figure 32. Inferred pathways of groundwater flow in relation to geology and structural controls, to the Lower Amargosa Valley from extra-basin contributing areas, California and Nevada. 
Thick and likely permeable Cenozoic basin-fill sediments are present to the northwest and southeast of Eagle Mountain (Blakely and Ponce, 2001), but there is no apparent subsurface connection between the two basins. The siliciclastic rocks exposed in the lower part of Eagle Mountain, along with an uplift of relatively impermeable Tertiary basin fill exposed immediately to the southwest, also form a barrier between these two areas. At the northwest tip of Eagle Mountain, the small perennial flow in the Amargosa River is likely because of the relatively impermeable playa claystone; there are no channel gravels to form an alluvial aquifer through which minimal end-of-summer discharge might flow. The flow of the river in this area, which is very small, may well represent most of the flow entering the Tecopa basin from the Amargosa Desert basin to the north.

The Pahrump Valley-California Valley flow path is likely characterized by westward interbasin flow through the carbonate-rock aquifer into and through California Valley, ending at Tule Spring (fig. 32). Runoff from Tule Spring supplies the flow in Willow Wash upstream of Willow Spring. The lack of significant channel deposits to form an alluvial aquifer allows this minor flow to support riparian vegetation along the channel.

\section{Groundwater Budget}

A long-term average water budget was developed to evaluate the balance between the flow into and out of the groundwater flow system in the LAV. The primary components of the water budget are recharge, natural discharge (ET and springflow), pumping, and lateral flow into and out of the LAV (interbasin flow). The following sections describe these budget components and provide estimates for the LAV.

\section{Recharge}

Groundwater recharge is defined as water that infiltrates downward through the unsaturated zone to the water table. Most of the groundwater recharge in the DVRFS originates from precipitation that falls on mountainous areas.

Total annual average recharge (net infiltration) for the LAV was estimated by Hevesi and others (2003) to be about 900 acre-ft using the net-infiltration model INFILv3. INFILv3 simulates surface-water flow, snowmelt, transpiration, and groundwater drainage in the root zone and has a climate algorithm that simulates daily climate conditions in local watersheds (Hevesi and others, 2003). Estimates of net infiltration help to quantify the amount of water moving downward across the root zone (Hevesi and others, 2003). Although net infiltration is not necessarily the same as recharge, it can be viewed as a reasonable indicator of groundwater recharge (Hevesi and others, 2003). In general, the uncertainty of approximating potential recharge from net infiltration increases as the thickness and heterogeneity of the unsaturated zone increases.

\section{Evapotranspiration and Springflow}

Investigations in the DVRFS estimated natural discharge by calculating evapotranspiration (ET) using micrometeorological measurements (Laczniak and others, 2001). The underlying assumption of this approach is that most of the groundwater issuing from springs and seeps within the discharge area ultimately is evaporated or transpired locally in the LAV and therefore is accounted for in estimates of ET. Thus, the groundwater discharge estimates to the AWSR from the seepage run are included in these estimates. In this report, ET refers to water evaporated or transpired from the regional groundwater flow system, not sourced from direct precipitation infiltrating into the basin fill and alluvium. Evapotranspiration estimates derived using the Bowen ratio method are published in Laczniak and others (2001). The total ET from the regional groundwater flow system in the LAV, as reported by Laczniak and others (2001), is about 8,500 acre-ft/yr.

The ET rates used by Laczniak and others (2001) were not measured in the LAV, but rather from other discharge areas within the DVRFS: Oasis Valley (Reiner and others, 2002) and Ash Meadows (Laczniak and others, 1999). The ET zones used by Laczniak and others (2001) for the Tecopa basin closely align themselves to the salt-encrusted areas along the AWSR (pl. 1).

Groundwater ET estimates by the Desert Research Institute (Huntington and others, 2016) were made using Landsat-derived vegetation indices and empirical relations for 1984 to 2015 imagery. The estimated groundwater ET compared reasonably well with that reported by Laczniak and others (2001), except for the southern part of the Shoshone area where ET estimates (2,082 acre-ft/yr) are approximately 30 percent greater than those estimated by Huntington and others (2016) (1,377 acre-ft/yr). Huntington and others (2016) indicate that the reason for this difference is that the ET units classified by Laczniak and others (2001) in the southern part of the Shoshone area were derived from June 1992 imagery that portrayed high vegetation vigor from high precipitation in 1992.

\section{Pumping}

Groundwater withdrawal (pumping) was estimated for the LAV for 2010. Potential groundwater withdrawal points in or near the town of Tecopa were located using satellite imagery. It was assumed that the water supply for Shoshone is from Shoshone Spring and that potable water for residents of Tecopa is supplied from commercial outside sources. Six commercial sites were identified for a total withdrawal of 15.5 acre-ft, and 70 households were identified for domestic use in the vicinity of Tecopa; domestic use was estimated to be 0.7 acre-ft per household in 2010. Using these assumptions for commercial and domestic use in the LAV from the early 1990s through 2010, it was estimated that 65 acre-ft/yr were used for water supply in the vicinity of Tecopa. 


\section{Interbasin Flow}

There is a large amount of groundwater in the LAV, as indicated by the multiple springs and seeps in the area. Evapotranspiration estimates for the LAV are $8,500 \mathrm{acre}-\mathrm{ft} / \mathrm{yr}$, which is nearly ten times greater than recharge derived from precipitation falling within the basin (900 acre-ft/yr). This indicates that most of the discharging water likely comes from interbasin flow. Interbasin flow to the LAV originates from Pahrump Valley and moves through Chicago and California Valleys in the carbonate-rock and basin-fill aquifers (Malmberg, 1967; Harrill, 1986; Harrill and others, 1988). Harrill (1986, table 7) reported a range of field and empirical estimates of recharge from 2,200 to 2,600 acre-ft/yr and evapotranspiration/pumping from 10,000 to $13,000 \mathrm{acre}-\mathrm{ft} / \mathrm{yr}$ ). Using a conservative difference of these two ranges of inflow and outflow results in 9,000 to 16,000 acre-ft/yr of interbasin flow out of Pahrump Valley. Laczniak and others (2001) reported ET from Chicago Valley to be $430 \mathrm{acre}-\mathrm{ft} / \mathrm{yr}$. Subtracting this Chicago Valley ET from the subsurface outflow from Pahrump Valley yields a range of interbasin flow entering the LAV through the carbonate-rock aquifer from 8,600 to 15,600 acre-ft/yr. A further maximum of 500 acre-ft/yr likely enters from the Amargosa Desert to the north through the basin-fill and alluvial deposits (Harrill and others, 1988). This results in a total of approximately 9,100 to 16,100 acre-ft/yr that enters the LAV through interbasin flow. Subtracting the components of discharge from the LAV (ET, springs, and a small amount of pumping) results in 1,400 to $8,400 \mathrm{acre}-\mathrm{ft} / \mathrm{yr}$ that exits the LAV to the west through the Black Mountains or to the southwest toward Saratoga Springs. Because of the uncertainty of these estimates, the lower range could be effectively zero (that is, there may be no significant groundwater flow out of the LAV). These interbasin flow estimates are based on assumed pre-development discharge estimates from Pahrump Valley and likely have been affected by any pumping that has occurred there. Anecdotal evidence (Andy Zdon \& Associates, 2014) suggests that discharge for some regional springs in the LAV (Chappo and Thom Springs) and Chicago Valley (Twelvemile Spring) was greater in the past.

\section{Local Flow Paths and Spring Hydrology}

There appear to be four different types of springs in the Tecopa basin on the basis of spring characteristics and geographic location. The type and location of springs are key to refining the existing generalized conceptual model. The geochemistry (see "Geochemistry of Groundwater and Springs" section) indicates that most of the water discharging from these springs is from the carbonate-rock aquifer, but can be substantially altered from the typical bicarbonate signature due to interactions with evaporites in the Tecopa lake beds. Table 15 presents a summary of the characteristics used for categorizing the following types of springs in the Tecopa basin:

- regional carbonate springs and seeps discharging west of the Amargosa River and in the ranges and valleys to the east,

- springs and seeps discharging on the east side of the Tecopa Hills,

- thermal springs and seeps discharging in the Tecopa Hot Springs resort area, and

- hillslope springs and seeps discharging along the east side of Amargosa Canyon.

\section{Regional Carbonate Springs and Seeps}

Regional springs sourced in the carbonate-rock aquifer in the DVRFS tend to have temperatures greater than $30^{\circ} \mathrm{C}$ and discharges greater than $0.6 \mathrm{ft}^{3} / \mathrm{s}$ (450 acre-ft/yr) (San Juan and others, 2010). In the LAV, these springs are considered to be those with temperatures between approximately 25 and $35^{\circ} \mathrm{C}$. Although measured direct discharge from Shoshone and Borax Springs is less than the characteristic $0.6 \mathrm{ft}^{3} / \mathrm{s}$ for a regional spring, ET in the area surrounding Shoshone is more than 2,000 acre-ft/yr. In the Tecopa basin, regional carbonate springs include Shoshone and Borax Springs on the east side of the basin. Other warms springs in the LAV include Chappo and Resting Spring in the Resting Spring Range, Twelvemile Spring in Chicago Valley, Willow Spring near China Ranch, and Tule Spring in California Valley (fig. 32).

A schematic cross section depicting the conceptualization of groundwater flow from the regional carbonate aquifer to springs in the LAV in shown on figure 33. In this schematic, groundwater moves westward through the carbonate-rock aquifer and into the China Ranch beds. A component of westerly flow also continues through the deep-seated carbonate-rock aquifer. Upon reaching the west side of the Tecopa basin, the water is forced upward along faults and barriers of low-permeability volcanic rock from both the carbonate-rock aquifer and the China Ranch beds, discharging at Shoshone and Borax Springs, as well as numerous seeps along the west side of the basin. A small amount of water may flow westward through the volcanic and carbonate rocks of the Dublin Hills, Greenwater Range, and Black Mountains.

The chemistry of the carbonate-rock aquifer water is modified by its movement through the China Ranch beds (inferred) and interaction with the Tecopa lake beds. Water discharging from the springs can move to the east just below or along the surface of the ground before entering the Amargosa River. Diffuse discharge between the west side of the Tecopa basin and the Amargosa River is indicated by areas of salt crust. 
Table 15. Observations and characteristics of springs in the Tecopa basin, Lower Amargosa Valley, California.

[ET, evapotranspiration; $\mathrm{m}^{3} / \mathrm{d}$, cubic meter per day; >, greater than]

\begin{tabular}{|c|c|c|c|c|c|}
\hline Hydrologic feature & Springs $^{1}$ & Hydrogeology & Physical hydrology & Geochemistry & Geographic location \\
\hline $\begin{array}{l}\text { Carbonate/ } \\
\text { regional } \\
\text { springs/seeps }\end{array}$ & $\begin{array}{l}\text { Shoshone Spring } \\
\text { Borax Spring } \\
\text { Chappo Spring } \\
\text { Resting Spring }\end{array}$ & $\begin{array}{l}\text { Presence of carbonate-rock aquifer in } \\
\text { Resting Spring Range and Nopah Range } \\
\text { allows regional flow paths } \\
\text { Salt crust indicates diffuse discharge }\end{array}$ & $\begin{array}{l}\text { Generally large flow volumes } \\
\left(>1,500 \mathrm{~m}^{3} / \mathrm{d}\right) \\
\text { Combined spring/ET discharge in } \\
\text { Shoshone and Borax Springs area of } \\
7,015 \mathrm{~m}^{3} / \mathrm{d} \\
\text { Chappo Spring discharge of } 30 \mathrm{~m}^{3} / \mathrm{d} \\
\text { Resting Spring discharge of } 9,000 \mathrm{~m}^{3} / \mathrm{d}\end{array}$ & $\begin{array}{l}\text { Shoshone and Borax } \\
\text { Springs show } \\
\text { bicarbonate waters } \\
\text { modified by } \\
\text { interaction with local } \\
\text { evaporite minerals }\end{array}$ & $\begin{array}{l}\text { West side of basin } \\
\text { and discharging } \\
\text { directly from } \\
\text { carbonate rock } \\
\text { on east side of } \\
\text { Resting Spring } \\
\text { Range }\end{array}$ \\
\hline $\begin{array}{l}\text { Tecopa Hills } \\
\text { springs/seeps }\end{array}$ & Thom Spring/seeps & $\begin{array}{l}\text { Low-permeability Tecopa Hills (Stirling } \\
\text { Quartzite) restricts groundwater flow } \\
\text { Presence of carbonate-rock aquifer in } \\
\text { Resting Spring Range } \\
\text { Lack of salt crust at land surface indicates } \\
\text { no diffuse discharge between Resting } \\
\text { Spring Range and Tecopa Hills } \\
\text { Salt crust along west side of Tecopa Hills } \\
\text { indicates discharge along flank of Tecopa } \\
\text { Hills from low-permeability rock }\end{array}$ & $\begin{array}{l}\text { Generally large flow volumes } \\
\left(>1,500 \mathrm{~m}^{3} / \mathrm{d}\right) \\
{ }^{2} \text { Thom Spring discharge of } 27 \mathrm{~m}^{3} / \mathrm{d}\end{array}$ & $\begin{array}{l}\text { Bicarbonate signature } \\
\text { indicates carbonate- } \\
\text { rock aquifer source, } \\
\text { and bypass of } \\
\text { evaporite deposits }\end{array}$ & $\begin{array}{l}\text { East side of the } \\
\text { Tecopa Hills }\end{array}$ \\
\hline $\begin{array}{l}\text { Thermal springs/ } \\
\text { seeps }\end{array}$ & $\begin{array}{l}\text { Borehole Spring } \\
\text { Tecopa Hot Springs } \\
\text { Wild Bath Spring }\end{array}$ & $\begin{array}{l}\text { Low-permeability Tecopa lake beds overlie } \\
\text { China Ranch beds } \\
\text { 6-kilometer horst structure allows deeply } \\
\text { circulating thermal groundwater to } \\
\text { discharge } \\
\text { Highly fractured and brecciated Stirling } \\
\text { Quartzite allows water to flow along } \\
\text { faults/fractures and through disrupted } \\
\text { rock which is normally low permeability }\end{array}$ & $\begin{array}{l}\text { Presence of confined groundwater system } \\
\text { beneath Tecopa lake beds in China } \\
\text { Ranch beds } \\
\text { ET estimates (inclusive of springflow) of } \\
\text { about } 12,100 \mathrm{~m}^{3} / \mathrm{d}\end{array}$ & $\begin{array}{l}\text { High concentrations of } \\
\text { total dissolved solids } \\
\text { Helium indicates deep } \\
\text { crust } / \text { mantle contact }^{3} \\
\text { Oxygen and hydrogen } \\
\text { signature similar to } \\
\text { other groundwater } \\
\text { in Lower Amargosa } \\
\text { Valley, indicating } \\
\text { similar sources }\end{array}$ & $\begin{array}{l}\text { Tecopa Hot Springs } \\
\text { resort area north of } \\
\text { the Tecopa Hills }\end{array}$ \\
\hline $\begin{array}{l}\text { Amargosa Canyon } \\
\text { hillslope } \\
\text { springs/seeps }\end{array}$ & Amargosa Canyon & $\begin{array}{l}\text { Tecopa lake beds not present south of } \\
\text { Tecopa Hills } \\
\text { Structural fault at southern end of } \\
\text { Amargosa Canyon spring line } \\
\text { Occurence of springs at China Ranch beds/ } \\
\text { Stirling Quartzite contact } \\
\text { Presence of tufa deposits in Amargosa } \\
\text { Canyon walls indicates carbonate water }\end{array}$ & $\begin{array}{l}\text { Unconfined system in China Ranch beds } \\
\text { Unconfined system in China Ranch beds } \\
\text { allows heat to dissipate } \\
\text { ET/spring discharge estimates of } \\
3,360 \mathrm{~m}^{3} / \mathrm{d}\end{array}$ & $\begin{array}{l}\text { Bicarbonate signature } \\
\text { indicates carbonate- } \\
\text { rock aquifer source }\end{array}$ & Amargosa Canyon \\
\hline
\end{tabular}

${ }^{1}$ Spring locations are shown on plate 1.

${ }^{2}$ Thom Spring and associated seeps along the east side of Tecopa Hills are included in upper Tecopa basin ET estimates reported by Faunt, Blainey, and others (2010) of about 12,100 cubic meters per day. Some anecdotal evidence suggests that when Borehole Spring was created, the discharge in Thom Spring dropped drastically.

${ }^{3}$ Davisson, 2015. 


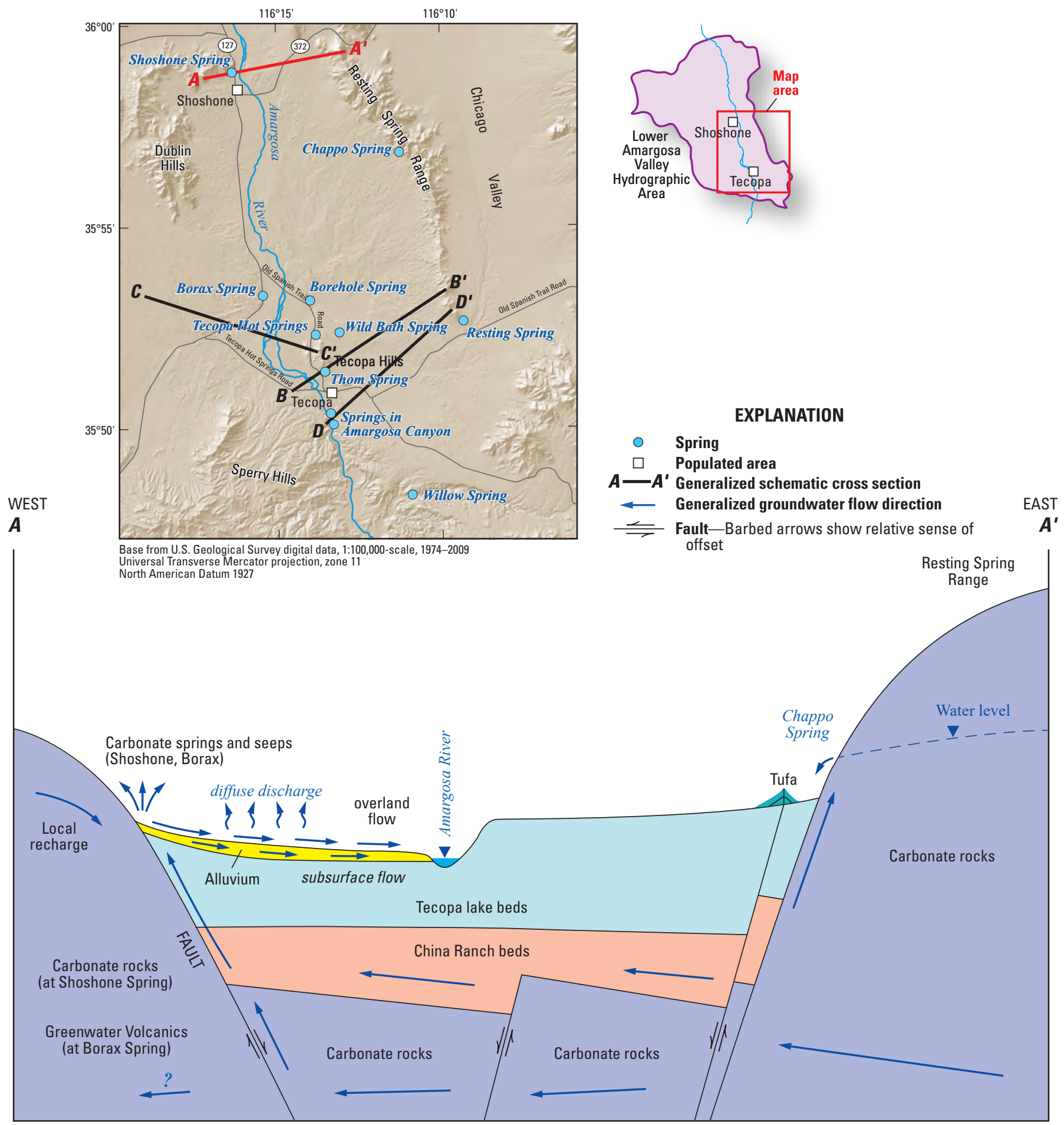

Not to scale

Figure 33. Generalized groundwater flow from the carbonate-rock aquifer to carbonate springs and seeps on the west side of the Tecopa basin, Lower Amargosa Valley, California. 


\section{Tecopa Hills Springs and Seeps}

On the east side of the Tecopa Hills, a series of springs and seeps exist that are delineated by vegetated areas and salt crust at similar altitudes. Figure 34 shows a schematic cross section of the conceptualization of groundwater flow that supplies the warm springs and a series of seeps along the east side of the Tecopa Hills. Groundwater discharging from the carbonate rock that makes up the Resting Spring Range enters the China Ranch beds and continues to move to the west under confined conditions. Upon intersecting the low-permeability siliciclastic rocks composing the Tecopa Hills, the water is forced upward, creating springs (including Thom Spring) and a band of seeps along the east side of the Tecopa Hills. The lack of a salt crust on the Tecopa lake beds between the Resting Spring Range and the Tecopa Hills indicates diffuse discharge is not occurring and that the lake beds are confining the groundwater.

\section{Thermal Springs and Seeps}

Thermal springs occur in the resort area of Tecopa, Calif., directly north of the town. These springs generally have temperatures greater than $35^{\circ} \mathrm{C}$. The immediate source of the thermal water for these springs and seeps appears to be from a confined system within the China Ranch beds beneath approximately $350 \mathrm{ft}$ of low-permeability Tecopa lake beds. The temperature of the springs indicates, however, a much deeper flow path for the water.

A conceptualization of the thermal flow system that provides water to the Tecopa Hot Springs area is shown on figure 35 . These thermal springs occur at the southern end of the 6-km horst, indicating that this faulted structure is the likely conduit for the deep thermal water. It is hypothesized that the elevated temperature of the water originates from the deeper parts of the regional flow system that enters faults and fractures in the siliciclastic rocks within the 6-km horst system and is forced upward to the surface. The recharge source of the water is likely the Spring Mountains, with deep flow paths through the carbonate-rock aquifer and possibly siliciclastic rocks. Based on oxygen and hydrogen isotope compositions, Larsen and others (2001) proposed that these waters are from the central Spring Mountains. Davisson (2015) also stated that the ${ }^{3} \mathrm{He}$ and ${ }^{4} \mathrm{He}$ ratios of these waters indicated a deep geothermal source in contact with the mantle along deep faults.

The thermal water discharges as seeps and springs along faults in the siliciclastic rocks, creating the hot springs area, and also discharges from wells drilled through the Tecopa lake beds where it is used for resort area activities. Runoff from the springs and subsurface flow through the alluvium moves toward the river, with some of it diffusely discharging between the hot spring area and the river channel, as indicated by salt crusts. The thermal water may also discharge into the China Ranch beds where it moves westward beneath the Amargosa River, cools, and discharges as seeps along the west side of the basin. Alternatively, water from these seeps may be sourced in the carbonate-rock aquifer, which then moves through the China Ranch beds and is forced upward after encountering low-permeability volcanic rocks of the Black Mountains or the Sheephead fault, similar to the conceptualization of the regional carbonate springs presented earlier (fig. 33). Runoff and subsurface flow through the surface alluvium moves toward the river. Diffuse discharge between the west side of the basin and the Amargosa River is indicated by salt crusts. A small amount of the deep-sourced thermal water may flow westward through the Dublin Hills and the Black Mountains toward Death Valley.

\section{Amargosa Canyon Hillslope Springs and Seeps}

A series of cooler (generally less than $25^{\circ} \mathrm{C}$ ) springs and seeps occur along hillslopes on the east side of Amargosa Canyon, directly feeding into the river. Geochemistry and tufa deposits indicate that these waters are sourced from the carbonate-rock aquifer. Furthermore, these springs contribute significant flows to the Amargosa River (see "Synoptic Seepage Run on the Amargosa Wild and Scenic River" section). The hillslope springs and seeps appear to exist only on the east side of the canyon at the contact of the relatively impermeable Stirling Quartzite and the China Ranch beds. In this area, just south of the Tecopa Hills, the low-permeability Tecopa lake beds do not exist and consist of a higher permeability shoreline facies overlying the permeable China Ranch beds.

Figure 36 depicts groundwater discharging from the carbonate-rock aquifer at the Resting Spring Range, entering the shoreline deposits of the Tecopa lake beds and the China Ranch beds, then moving westward toward the Amargosa Canyon, which dissects the China Ranch beds. The unconfined and shallow nature of this local system presumably allows the warmer water from the carbonate-rock aquifer to lose heat and cool as it moves from the Resting Spring Range to discharge as a line of springs for approximately $1.3 \mathrm{mi}$ along the Amargosa River within Amargosa Canyon, just south of Tecopa. The springline is truncated by a fault, which relatively downdrops the Stirling Quartzite, resulting in a thicker section of China Ranch beds south of the fault. There may be minor upward leakage into the Amargosa River, but the synoptic seepage run indicates that all groundwater discharge of these cooler springs occurs north of the fault. 


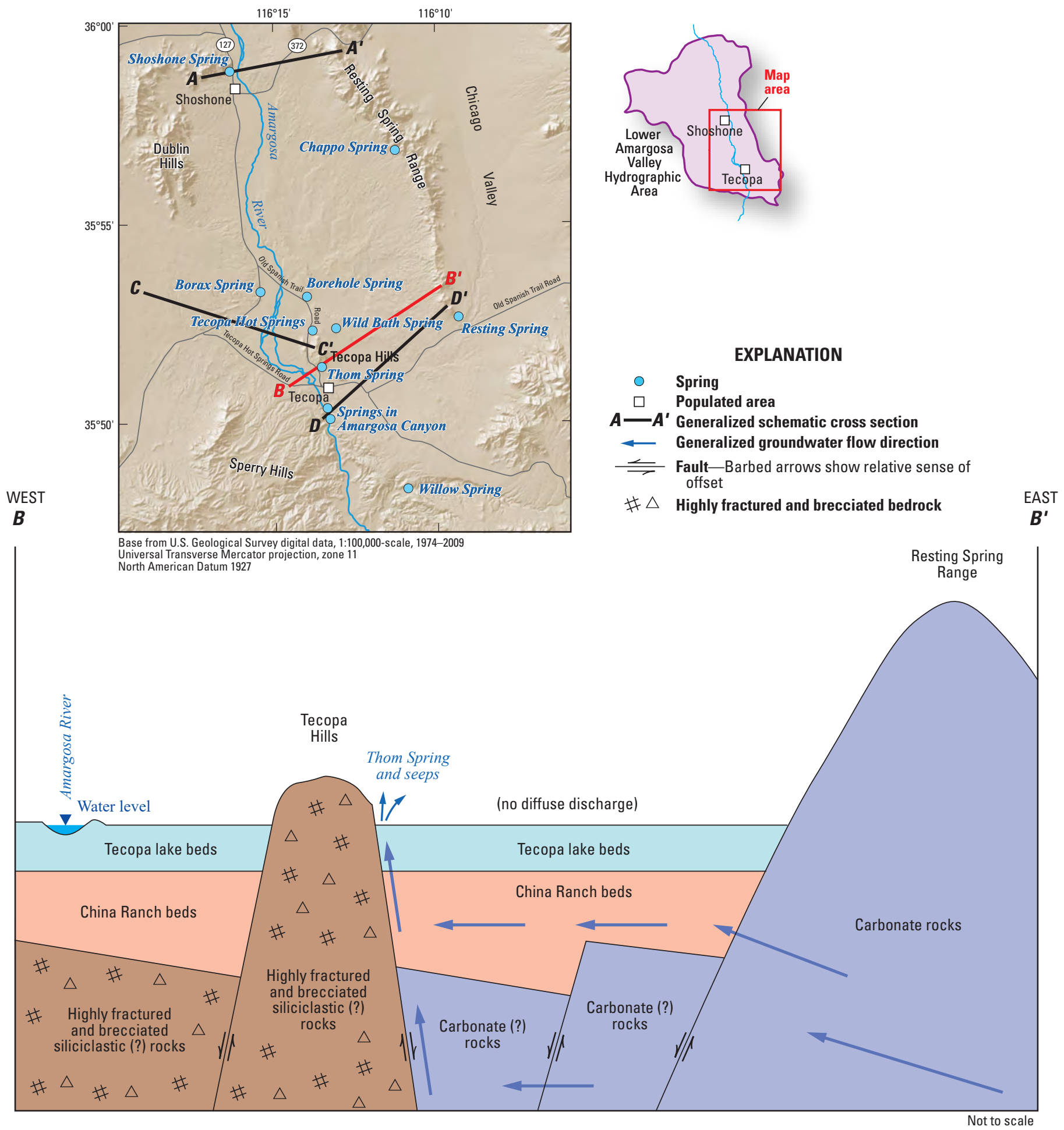

Figure 34. Generalized groundwater flow from the carbonate-rock aquifer to springs and seeps on the east side of the Tecopa Hills, Lower Amargosa Valley, California. 


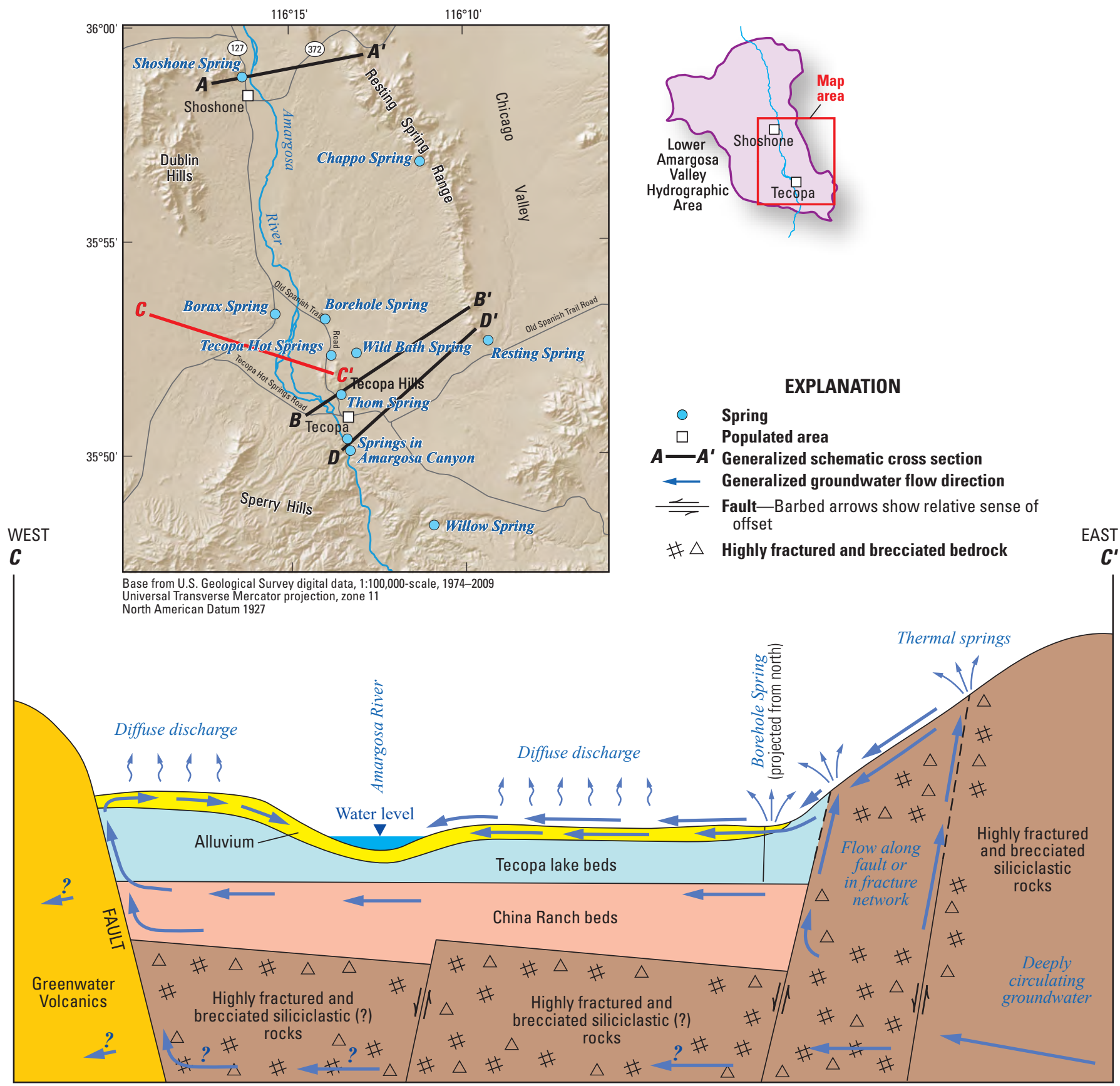

Not to scale

Figure 35. Generalized groundwater flow from siliciclastic rocks to thermal springs and the Amargosa River, Lower Amargosa Valley, California. 


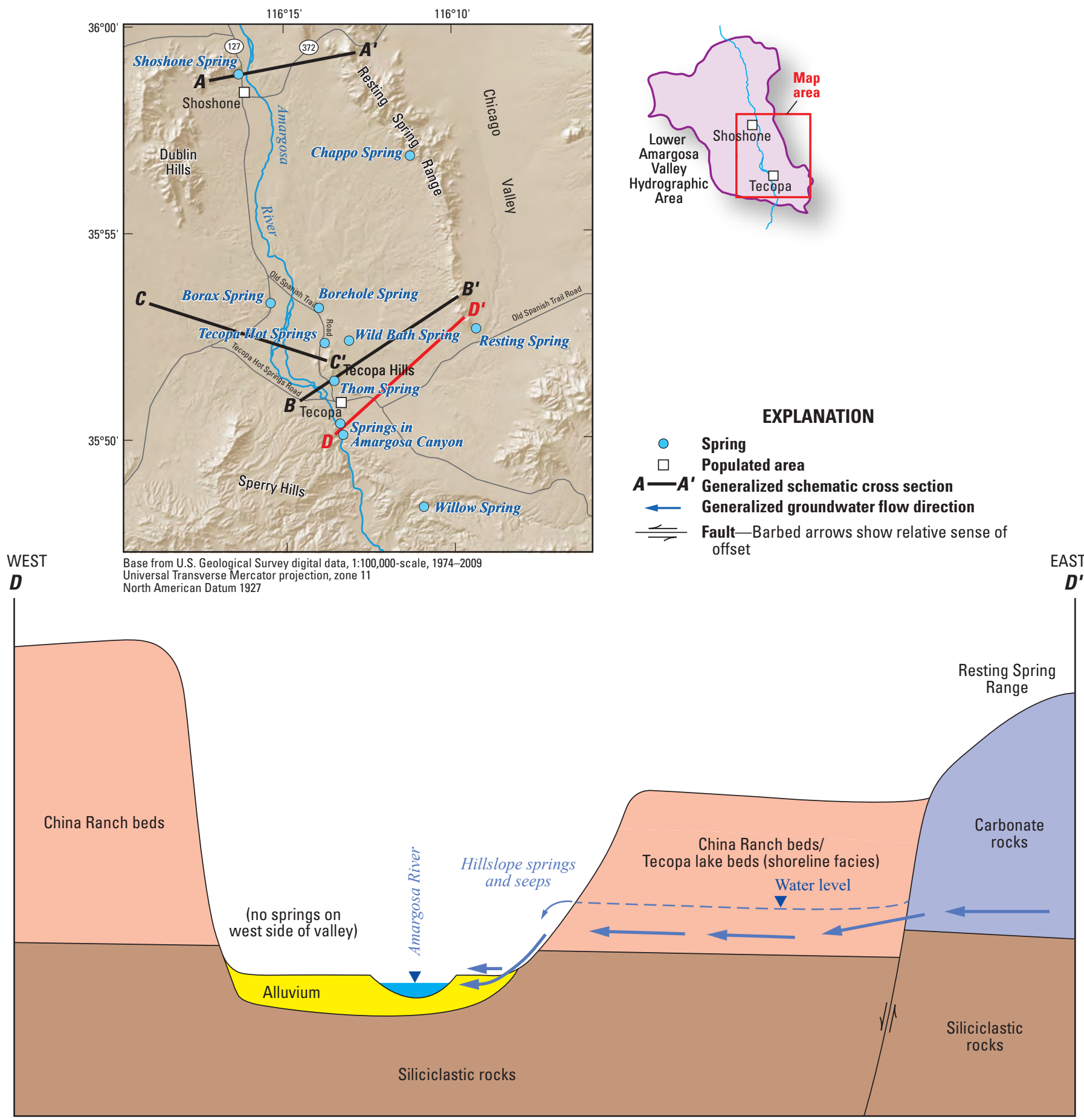

Not to scale

Figure 36. Generalized groundwater flow from the carbonate-rock aquifer to hillslope springs and seeps on the east side of Amargosa Canyon, Lower Amargosa Valley, California. 


\section{Conceptual Model Discussion}

A conceptualization of the groundwater flow system for the Tecopa basin incorporating regional flow lines (fig. 32) with conceptual models of flow to the springs in the basin (figs. 33-36) is shown on figure 37. The blue arrows represent regional flow paths in the carbonate-rock aquifer, and the orange arrows represent more localized (shallow) flow paths in alluvial deposits and younger rocks within the Tecopa basin. Regional flow paths depict the direction of flow of water from its source in the Spring Mountains (fig. 32) through the Resting Spring Range to the Tecopa basin. Some regional water discharges on the east side of the basin (west side of the Resting Spring Range) at Chappo Spring, due to upward flow along front-range faults. Regional water also discharges from the carbonate-rock aquifer along faults on the west side of the basin between Shoshone and Borax Springs (fig. 37). As shown on plate 1, regional flow arrows in the southern part of the Nopah Range are depicted as perpendicular to the potentiometric contours, but actual flow paths are likely more tortuous through the carbonate rocks, reflecting a more localized flow component. Westward flowing regional groundwater also moves from the carbonate-rock aquifer in the Resting Spring Range into the China Ranch beds (pl. 1).

Water discharging from springs and seeps along the west side of the basin between Shoshone and Borax Springs moves as surface runoff and shallow flow (orange arrows) toward the AWSR to the east through alluvial deposits above the Tecopa lake beds. Some of this water is diffusely discharged leaving behind salt-encrusted soils, and some discharges into the AWSR (fig. 37). Regional groundwater enters the 6-km horst block, having been warmed at depth to produce thermal water that is in a confined system in the China Ranch beds beneath the Tecopa lake bed deposits. Thermal water discharges along faults penetrating the siliciclastic rock and in boreholes and wells drilled through the confining layer of the Tecopa lake beds. Regional groundwater flowing to the west through the China Ranch beds under confined conditions (orange arrows) intersects the low-permeability Tecopa Hills, creating warm seeps and springs on the east side of the Tecopa Hills (fig. 37). Farther to the south, the China Ranch beds are not overlain by the Tecopa lake beds, allowing for an unconfined flow system. Water discharging from the carbonate-rock aquifer composing the Resting Spring Range enters the China Ranch beds and the shoreline facies of the Tecopa lake beds, resulting in an unconfined flow system. Groundwater then flows to the west (orange arrows), losing heat as it does, and discharges along the walls of the Amargosa Canyon (fig. 37).

The conceptualization described in this report builds upon and refines the existing regional conceptualizations described by Winograd and Thordarsen (1975), Harrill and others (1988), and Faunt, D'Agnese, and O'Brien (2010); this conceptualization describes specific flow paths from the Spring Mountains and the type and location of springs in the Tecopa basin. Most of the discharge of the springs and diffuse discharge in the Tecopa basin is ultimately sourced in the carbonate-rock aquifer, with flow moving southwest from its source in the Spring Mountains through the Nopah and Resting Spring Ranges. Larsen and others (2001) and this report show that the waters of the Tecopa basin are largely from the Spring Mountains through the carbonate-rock aquifer. A small component of flow also occurs from the Amargosa Desert south into the LAV through the basin-fill deposits.

Nelson and others (2001) largely agree with the previous conceptualization of regional interbasin flow. They report that the potentiometric contours of D'Agnese and others (1997) show flow from the Spring Mountains to the southwest into the Tecopa basin through the Nopah and Resting Spring Ranges. In contrast, Miner and others (2007) show that interbasin flow through these ranges dominated by carbonate rocks is unlikely due to stratigraphic and structural complexity, and that flow from the Spring Mountains is along a north-south-trending fault zone from Ash Meadows to the Tecopa basin. This conceptualization does not consider the physical hydrology and hydrogeology utilized in the previous regional conceptualizations (Harrill and others, 1988; Harrill and others, 1998), such as the lack of a large volume of carbonate rock to convey significant amounts of water (see "Hydrogeologic Controls" section) and regional water levels (see "Groundwater" section). Miner and others (2007) also indicate that water discharging in the Tecopa basin has a large component of locally recharged water. This conceptualization is untenable; however, due to the low amount of local recharge in the LAV (see "Groundwater Budget" section); not enough local recharge appears to be present to supply the significant amount of spring and diffuse discharge in the Tecopa basin. As indicated in the "Groundwater Budget" section, recharge for the LAV is only about one-tenth of the total discharge in the LAV. Furthermore, the warm springs indicate regional flow at depth and along substantially long flow paths rather than along shorter and shallower flow paths of local recharge.

Zdon and others (2015) proposed that the water discharging from Shoshone Spring is sourced from water in the basin-fill deposits of the Amargosa Desert. According to this conceptualization, this water is confined beneath the Tecopa lake bed deposits and flows southward until it reaches the discharge point at Shoshone Spring. A well (ARHS-01) drilled south of Eagle Mountain for the Amargosa Conservancy contains water that is relatively warm $40+{ }^{\circ} \mathrm{C}$ at a depth of over $100 \mathrm{ft}$. Chemical analyses of water samples from this well indicate that the water is similar to that of Ash Meadows. More data are needed, however, to definitively link these waters to those in the basin-fill deposits of the Amargosa Desert. An alternative explanation, based on the carbonate geochemical signature and temperature, is that the warm water in well ARHS-01 is from the carbonate-rock aquifer where it terminates just south of Eagle Mountain at the northern end of the LAV. This hypothesis seems to agree with recent and previous conceptualizations (such as that of Harrill and others, 1998) of regional flow into the LAV. 


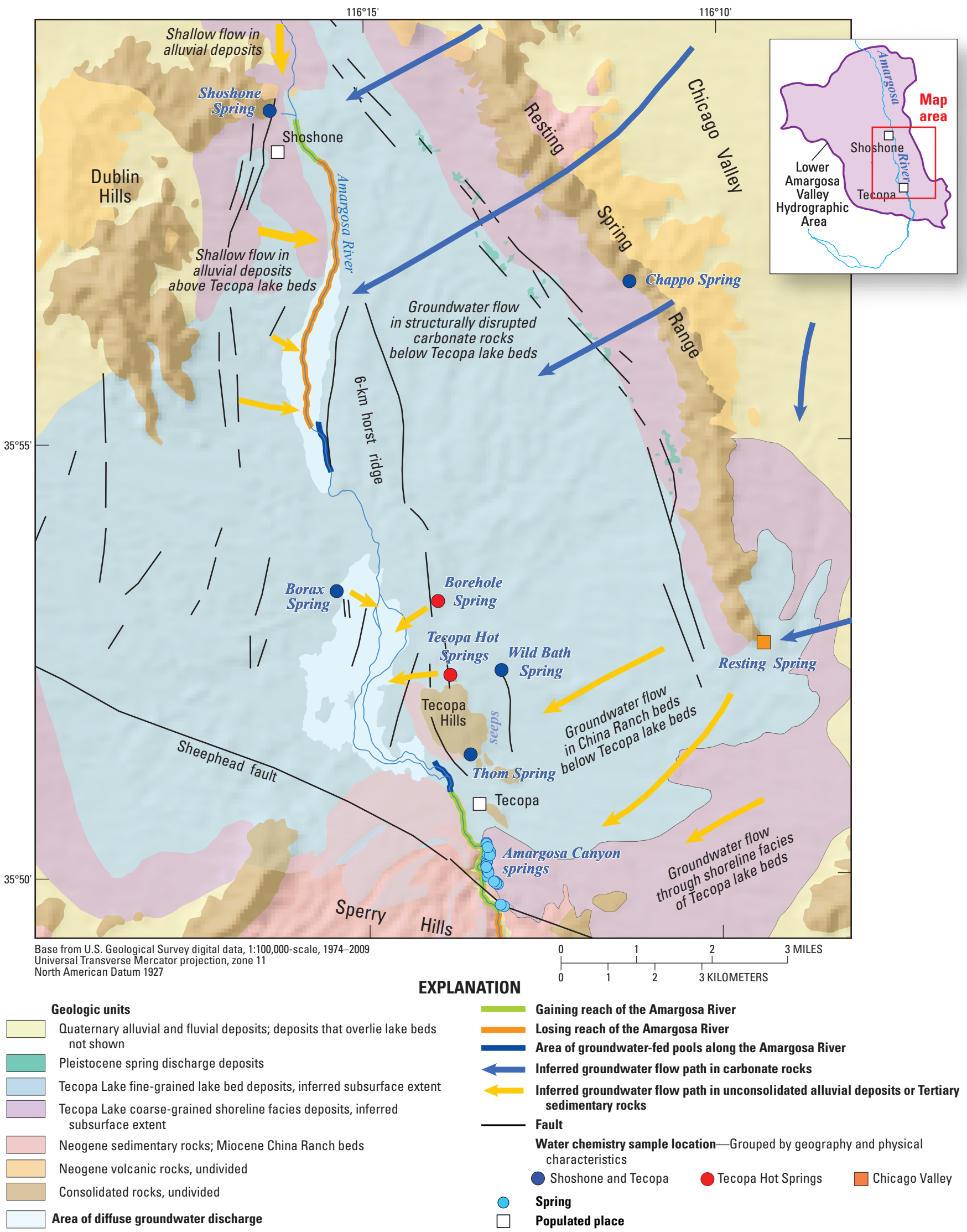

Figure 37. Conceptualization of the groundwater flow system in carbonate rocks, and unconsolidated alluvial deposits and sedimentary rocks, in the Tecopa basin, Lower Amargosa Valley, California. 
Although the conceptualization of the LAV surfacewater and groundwater hydrology has been considerably refined, there are limitations, mainly with respect to the hydrogeology, physical hydrology, and water chemistry. As with any conceptualization, the one presented in this report has limitations. These limitations include (1) availability of lithologic, water-level, and chemical data, (2) estimates of water budget components, and (3) spring discharge measurements. The limitations of this work can be lessened by increased data from wells to obtain information on stratigraphy, water levels, and water chemistry of both the shallow and deep groundwater systems, especially of the carbonate-rock aquifer. More information on these aspects could help refine and improve the conceptualization.

Considerable uncertainty exists in the interpretation of subsurface hydrogeology. In parts of the study area the extent of carbonate rocks and continuity of the aquifer is essentially unknown and only inferred from available data. For example, the extent, continuity, and hydraulic properties of Paleozoic carbonate rocks beneath Pahrump, Chicago, and California Valleys and the Tecopa basin are basically unknown. An extensive and expensive drilling program would be required to address this kind of uncertainty, although in places geophysics would aid in defining the subsurface extent and geometry of the Paleozoic carbonate rocks.

The hydraulic properties of the carbonate-rock aquifer are also uncertain and largely unknown in the Tecopa basin. There has been some aquifer testing of the carbonate-rock aquifer in the DVRFS (Belcher and others, 2001), but none in the Tecopa basin. Although an upward gradient from the carbonate-rock aquifer and the overlying basin fill is inferred from regional potentiometric data, the hydraulic connection between them remains uncertain. The properties of faults in the Tecopa basin and larger study area are also uncertain and largely unknown, particularly with regard to their function as barriers or conduits, and their interconnectivity.

In large parts of the study area, there is also a lack of water-level data. Interpretation is hampered by the absence of water levels southwest of Pahrump Valley and at the southern end of the Amargosa Desert. Multiple-completion wells would be required to evaluate the extent of the shallow (alluvial and basin fill) and deep (carbonate) flow systems and their degree of connectivity.

The water balance is limited by the estimated values and uncertainties of the components that make up the overall water budget. Estimates of ET are based on rates outside of the LAV, and measurements of ET within the basin would provide more accurate estimates, which could improve the overall water budget. The number of pumping wells, their locations, and their pumping rates were all estimated or assumed. A beneficial use survey to assess the actual locations and pumping rates of domestic wells in the vicinity of Tecopa could greatly improve the pumpage component of the water budget. Other components, such as recharge and interbasin flow, are limited by the inherent uncertainties in these estimates, which are described in the literature from which they were obtained.

The seepage run interpretation is limited by the scope of the measurements - only a single seepage run was completed for this study. Although the data were collected during a low ET and non-storm event period (potentially isolating the spring discharge component to the AWSR), no seasonal or year-to-year variability was assessed. Multiple seepage runs over several years could aid in assessing variability in groundwater and spring discharge to the ASWR.

Future studies would benefit from additional data collection, including surface-water chemistry samples, to better understand the relation between surface water and groundwater. Additional groundwater samples along the flow path would greatly improve geochemical interpretations. Additional samples collected from existing wells within the study area would also enhance interpretation of geochemical data and give insight into subsurface processes. The collection of more precipitation samples for stable-isotope analysis from different altitudes and seasons in the same potential recharge areas, could also greatly aid in assessing flow paths and source areas for groundwater in the regional system. Future analyses should also include trace elements, which may yield additional insight into sources of groundwater.

\section{Summary}

The conceptual model of the groundwater system of the Lower Amargosa Valley (LAV), at the time of this study, builds on the existing generalized regional conceptualization and attempts to explain how diverse types of springs occur in the same basin. This study integrates several lines of evidence and types of data to identify likely groundwater flow paths; no single type of data is definitive, yet taken together, these multiple lines of evidence tend to consistently support the model proposed in this report. These lines of evidence include (1) permitted/likely groundwater flow paths based on inferred subsurface geology, (2) water-budget considerations including magnitude of streamflow and spring discharge in relation to likely local and subregional recharge components, (3) geochemical and isotopic analyses of LAV springs and comparison to spring and precipitation chemistry in surrounding regions, and (4) geochemical modeling of permitted/likely flow paths. The conceptualization takes into account local data, including gaining and losing reaches of the Amargosa River, and the presence of springs with specific characteristics (temperature, chemistry, isotopic signature) in specific parts of the Tecopa basin.

Perennial flow in the Wild and Scenic sections of the Amargosa River is mostly supplied by groundwater discharge. Hydrologic and geochemical data indicate that perennial flow in the river is likely from groundwater that has recharged outside of the LAV through the regional carbonaterock aquifer from the Spring Mountains as interbasin flow. 
The carbonate-rock aquifer extends from western Utah through central and southern Nevada, and terminates in eastern California, near the western boundary of the LAV.

Groundwater in the southern Death Valley subregion primarily is derived from recharge in the Spring Mountains and to a lesser extent from recharge in the Nopah, Kingston, and Greenwater Ranges. The geochemistry indicates that most of the water in the system is from the carbonate-rock aquifer, but can be substantially altered from the typical bicarbonate signature due to interaction with evaporites in the Tecopa lake beds.

Groundwater is abundant in the LAV, as indicated by the multiple springs and seeps in the area. Estimated evapotranspiration rates for the LAV are at least

8,500 acre-feet per year, almost ten times greater than the estimated local recharge (900 acre-feet per year), indicating that the discharging water is sourced from outside the basin (interbasin flow).

Three potential groundwater flow paths can be inferred from the subsurface hydrogeology: (1) westward subsurface flow from the Spring Mountains beneath Pahrump Valley to the northern half of the Nopah Range through the carbonaterock aquifer, (2) southward flow from the Amargosa Desert in Cenozoic basin-fill deposits, and shallow subsurface flow in the Amargosa River channel and associated alluvial deposits (thought to be relatively small), and (3) southwestward flow from the Spring Mountains beneath Pahrump Valley to California Valley through the carbonate-rock aquifer.

Four different types of springs (based on type and location) can be identified in the LAV:

- regional carbonate springs and seeps discharging west of the Amargosa River and in the ranges and valleys to the east,

- springs and seeps discharging on the east side of the Tecopa Hills,

- thermal springs and seeps discharging in the Tecopa Hot Springs resort area, and

- hillslope springs and seeps discharging along the east side of Amargosa Canyon.

The regional carbonate springs (Shoshone and Borax Springs) and seeps tend to occur along the west side of the Tecopa basin from Shoshone to the Old Spanish Trail road, although several regional springs occur in the ranges and valleys to the east of the basin. The chemistry of both springs has been modified by dissolution of the evaporite deposits or volcanic rocks, even though sourced in the carbonate-rock aquifer. Groundwater moves westward through the carbonaterock aquifer and into the China Ranch beds. A component of westerly flow also continues deeper through the carbonaterock aquifer. Upon reaching the west side of the Tecopa basin, the water is forced upward from both the carbonate-rock aquifer and the China Ranch beds along faults, discharging at Shoshone and Borax Springs, as well as at numerous seeps along the west side of the basin. The chemistry of the carbonate-rock aquifer water is modified as it moves through the China Ranch beds and as it interacts with the Tecopa lake beds. Water discharging from the springs can move to the east just along or below the surface of the ground to discharge into the Amargosa River. Diffuse discharge between the west side of the Tecopa basin and the Amargosa River is indicated by areas of salt crust.

Springs and seeps discharge along the eastern flank of the Tecopa Hills. Groundwater discharging from the carbonaterock aquifer that makes up the Resting Spring Range likely enters the China Ranch beds and continues to move west under confined conditions produced by the overlying Tecopa lake beds. Upon intersecting the low-permeability siliciclastic rocks composing the Tecopa Hills, the water is forced upward, discharging as springs and as a band of seeps along the east side of the Tecopa Hills, which are visible as vegetated areas and salt crusts at similar altitudes. The lack of a salt crust on the Tecopa lake beds between the Resting Spring Range and the Tecopa Hills indicates no diffuse discharge occurs and that the lake beds are confining the groundwater.

Thermal springs occur in the resort area of Tecopa, California, directly north of the town. These springs generally have temperatures greater than $35^{\circ} \mathrm{C}$. The hot water for these springs and seeps appears to originate from a confined system within the China Ranch beds beneath approximately 350 feet of low-permeability Tecopa lake beds. These thermal springs occur at the southern end of the 6-km horst, where water from the deeper parts of the regional flow system enters faults and fractures in the siliciclastic rocks and is forced upward. The water is likely sourced in the carbonate-rock aquifer.

The hillslope springs and seeps occur along the east side of the Amargosa Canyon at the contact of the China Ranch beds and the underlying low-permeability Stirling Quartzite. The temperatures of these springs and seeps are generally less than $25^{\circ} \mathrm{C}$. Chemical analyses indicate that these waters are sourced in the carbonate-rock aquifer, likely from the Spring Mountains. Tufa deposits from the seeps and springs indicate calcium carbonate saturation, further supporting a source from the carbonate-rock aquifer. In this area, just south of the Tecopa Hills, the low-permeability Tecopa lake beds are not present, and instead, consist of the higher-permeability shoreline facies overlying the permeable China Ranch beds. Groundwater discharges from the carbonate-rock aquifer in the Resting Spring Range and enters the shoreline deposits of the Tecopa lake beds and the China Ranch beds, moving to the west toward the Amargosa Canyon, which dissects the China Ranch beds. The unconfined nature of this local system allows warmer water from the carbonate-rock aquifer to cool as it moves to discharge points along the Amargosa Canyon. The approximately 1.3 mile-long springline is truncated by a fault, which downdrops the Stirling Quartzite. This thicker section of China Ranch beds south of the fault allows water to potentially bypass the river channel. 
Perennial flow from springs to the Amargosa River appears to begin in the vicinity of the hot springs near Tecopa. Persistent groundwater-fed pools appear along the river channel just south of the Tecopa Hills; flow between the pools is evident, but difficult to measure. During a synoptic seepage run, flow in the Amargosa River at the Tecopa streamgage was about 1 cubic foot per second $\left(\mathrm{ft}^{3} / \mathrm{s}\right)$. South (downstream) of the Tecopa gage, a line of hillslope springs and seeps occurs along the east side of the river channel through Amargosa Canyon. At the southern end of this line of springs, the flow in the river was just over $4 \mathrm{ft}^{3} / \mathrm{s}$; this increase of approximately $3 \mathrm{ft}^{3} / \mathrm{s}$ presumably is from the cool springs in Amargosa Canyon. Downstream of this reach, the flow in the river decreased to $3 \mathrm{ft}^{3} / \mathrm{s}$ until below the confluence of Willow Creek, where the river consistently loses flow; no flow is present in the river channel just north of Dumont Dunes. At other times of the year, flow has been observed in the Amargosa River well past Dumont Dunes.

\section{References Cited}

Andy Zdon \& Associates, Inc., 2014, State of the basin report, Amargosa River basin, Inyo and San Bernardino Counties, California and Nye County, Nevada: Report prepared for the Nature Conservancy, Pasadena, Calif., 60 p., 7 appendixes.

Ball, J.W., and Nordstrom, D.K., 1991, User's manual for WATEQ4F, with revised thermodynamic data base and test cases for calculating speciation of major, trace, and redox elements in natural waters: U.S. Geological Survey OpenFile Report 91-183, 188 p.

Bedinger, M.S., and Harrill, J.R., 2010, Appendix 1. Regional potential for interbasin flow of groundwater, in Belcher, W.R., and Sweetkind, D.S., eds., Death Valley regional groundwater flow system, Nevada and CaliforniaHydrogeologic framework and transient groundwater flow model: U.S. Geological Survey Professional Paper 1711, p. 347-364, http://pubs.usgs.gov/pp/1711/.

Bedinger, M.S., Langer, W.H., and Reed, J.E., 1989, Groundwater hydrology, in Bedinger, M.S., Sargent, K.A., and Langer, W.H., eds., Studies of geology and hydrology in the Basin and Range Province, southwestern United States, for isolation of high-level radioactive waste - Characterization of the Death Valley region, Nevada and California: U.S. Geological Survey Professional Paper 1370-F, 49 p., 8 pls. in pocket.

Belcher, W.R., Bedinger, M.S., Back, J.T., and Sweetkind, D.S., 2009, Interbasin flow in the Great Basin with special reference to the southern Funeral Mountains and the source of Furnace Creek springs, Death Valley, California, U.S.: Journal of Hydrology, v. 369, p. 30-43.
Belcher, W.R., Elliott, P.E., and Geldon, A.L., 2001, Hydraulic-property estimates for use with a transient regional ground-water flow model of the Death Valley regional ground-water flow system, Nevada and California: U.S. Geological Survey Water-Resources Investigations Report 01-4120, 28 p., 1 pl.

Belcher, W.R., and Sweetkind, D.S., eds., 2010, Death Valley regional groundwater flow system, Nevada and CaliforniaHydrogeologic framework and transient groundwater flow model: U.S. Geological Survey Professional Paper 1711, $398 \mathrm{p}$.

Benson, Lyman, and Darrow, R.A., 1981, Trees and shrubs of the southwestern deserts: Tucson, University of Arizona Press, $416 \mathrm{p}$.

Blakely, R.J., Morin, R.L., McKee, E.H., Schmidt, K.M., Langenheim, V.E., and Dixon, G.L., 1998, Threedimensional model of pre-Cenozoic basement beneath Amargosa Desert and Pahrump Valley, California and Nevada - Implications for tectonic evolution and water resources: U.S. Geological Survey Open-File Report 98-496, 29 p.

Blakely, R.J., and Ponce, D.A., 2001, Map showing depth to pre-Cenozoic basement in the Death Valley groundwater model area, Nevada and California: U.S. Geological Survey Miscellaneous Field Studies Map MF-2381-E, scale 1:250,000.

Buchanan, T.J., and Somers, W.P., 1969, Discharge measurements at gaging stations: U.S. Geological Survey Techniques of Water-Resources Investigations, book 3, chap. A8, 65 p.

Burchfiel, B.C., Hamill, G.S., and Wilhelms, D.E., 1982, Stratigraphy of the Montgomery Mountains and the northern half of the Nopah and Resting Spring Ranges, Nevada and California: Geological Society of America Map and Chart Series MC-44, scale 1:62,500.

Burchfiel, B.C., Hamill, G.S., and Wilhelms, D.E., 1983, Structural geology of the Montgomery Mountains and the northern half of the Nopah and Resting Spring Ranges, Nevada and California: Geological Society of America Bulletin, v. 94, p. 1359-1376.

Bushman, M.A., Nelson, S.T., Tingey, D., and Eggett, D., 2010, Regional groundwater flow in structurally complex extended terranes-An evaluation of the sources of discharge at Ash Meadows, Nevada: Journal of Hydrology, v. 386, p. 118-129.

Calzia, J.P., Troxel, B.W., Wright, L.A., Burchfiel, B.C., Davis, G.A., and McMackin, M.R., 2000, Geologic map of the Kingston Range, southern Death Valley, CA: U.S. Geological Survey Open-File Report 00-412, scale $1: 24,000$. 
Carr, W.J., Grow, J.A., and Keller, S.M., 1995, Lithologic and geophysical logs of drill holes Felderhoff Federal 5-1 and 25-1, Amargosa Desert, Nye County, Nevada: U.S. Geological Survey Open-File Report 95-155, 14 p.

Caskey, J., and Reheis, M., 2014, Pleistocene lake transgressions, paleohydrologic environments, and stratigraphy of the Tecopa basin - Constraints on the integration history of the Amargosa River: Field guide for the Pacific Cell, Friends of Pleistocene field trip, November 7-9, 2014, accessed November 13, 2015, at http://www.fop.cascadiageo.org/pacific_cell/2014/FOP_ PACCELL_2014_GUIDEBOOK.pdf.

Chesterman, C.W., 1973, Geology of the northeast quarter of Shoshone quadrangle, Inyo County, California: California Division of Mines and Geology, Map Sheet 18, scale $1: 24,000$.

Claassen, H.C., 1985, Sources and mechanisms of recharge for ground water in the west-central Amargosa Desert, Nevada-A geochemical interpretation: U.S. Geological Survey Professional Paper 712-F, 66 p.

Clark, I.D., and Fritz, P., 1997, Environmental isotopes in hydrogeology: Boca Raton, New York, Lewis Publishers, $328 \mathrm{p}$.

Coplen, T.B., 1993, Uses of environmental isotopes, in Alley, W.M., ed., Regional ground-water quality: New York, Van Nostrand Reinhold, p. 227-254.

Craig, H., 1961, Isotopic variations in meteoric waters: Science, v. 133, no. 3465, p. 1702-1703.

D'Agnese, F.A., Faunt, C.C, Turner, A.K., and Hill, M.C., 1997, Hydrogeologic evaluation and numerical simulation of the Death Valley regional ground-water flow system, Nevada and California: U.S. Geological Survey WaterResources Investigations Report 96-4300, 124 p.

Davisson, M.L., 2015, Constraints on the recharge sources, flowpaths, and ages of groundwater in the Amargosa River Valley using stable isotope, water quality, and noble gas data: M.L. Davisson and Associates report to County of Inyo Planning Department, Independence, California.

Denny, C.S., and Drewes, H., 1965, Geology of the Ash Meadows quadrangle, Nevada-California-The history of a desert basin and its bordering highlands: U.S. Geological Survey Bulletin 1181-L, 56 p., 1 pl., scale 1:62,500.

Dettinger, M.D., Harrill, J.R., Schmidt, D.L., and Hess, J.W., 1995, Distribution of carbonate-rock aquifers and the potential for their development, southern Nevada and parts of Arizona, California, and Utah: U.S. Geological Survey Water-Resources Investigations Report 91-4146, 100 p.
Drakos, P., and Hodgins, M., 2013, Assessment of selected springs and wells in the Pahrump Valley and western Spring Mountains, Nye County, Nevada: Glorietta Geoscience, Inc., $56 \mathrm{p}$.

Drever, J.I., 1982, The geochemistry of natural waters: Englewood Cliffs, N.J., Prentice-Hall, 388 p.

Dudley, W.W., Jr., and Larsen, J.D., 1976, Effect of irrigation pumping on desert pupfish habitats in Ash Meadows, Nye County, Nevada: U.S. Geological Survey Professional Paper 927, 52 p.

Edmunds, W.M., and Smedley, P.L., 2000, Residence time indicators in groundwater-The East Midlands Triassic sandstone aquifer: Applied Geochemistry, v. 15, no. 6 , p. $737-752$.

Faunt, C.C., 1997, Effect of faulting on ground-water movement in the Death Valley region, Nevada and California: U.S. Geological Survey Water-Resources Investigations Report 95-4132, 42 p.

Faunt, C.C., Blainey, J.B., Hill, M.C., D'Agnese, F.A., and O'Brien, G.M., 2010, Chapter F. Transient flow model, in Belcher, W.R., and Sweetkind, D.S., eds., Death Valley regional groundwater flow system, Nevada and CaliforniaHydrogeologic framework and transient groundwater flow model: U.S. Geological Survey Professional Paper 1711, p. 251-344.

Faunt, C.C., D'Agnese, F.A., and O’Brien, G.M., 2010, Chapter D. Hydrology, in Belcher, W.R., and Sweetkind, D.S., eds., Death Valley regional groundwater flow system, Nevada and California-Hydrogeologic framework and transient ground-water flow model: U.S. Geological Survey Professional Paper 1711, p. 133-159.

Faunt, C.C., D’Agnese, F.A., and Turner, A.K., 1997, A hydrogeologic map of the Death Valley region, Nevada and California, developed using GIS techniques: U.S. Geological Survey Water-Resources Investigations Report 95-4016, 18 p., 1 pl., scale 1:500,000.

Faunt, C.C., Sweetkind, D.S., and Belcher, W.R., 2010, Chapter E. Hydrogeologic framework model, in Belcher, W.R., and Sweetkind, D.S., eds., Death Valley regional ground-water flow system, Nevada and California-Hydrogeologic framework and transient ground-water flow model: U.S. Geological Survey Professional Paper 1711, p. 161-250.

Fenelon, J.M., Sweetkind, D.S., and Laczniak, R.J., 2010, Groundwater flow systems at the Nevada Test Site, Nevada - A synthesis of potentiometric contours, hydrostratigraphy, and geologic structures: U.S. Geological Survey Professional Paper 1771, 54 p., 6 pls. 
Fenneman, N.M., 1931, Physiography of the western United States: New York, McGraw-Hill Book Company, 534 p.

Foley, J., Roy, A., and Clifford, D., 2014, Translocation and captive propagation of the Amargosa vole-Preliminary assessment of need, feasibility, and protocols: California Department of Fish and Wildlife, Sacramento, Calif., 40 p.

Fridrich, C.J., and Thompson, R.A., 2011, Cenozoic tectonic reorganizations of the Death Valley region, southeast California and southwest Nevada: U.S. Geological Survey Professional Paper 1783, 36 p., 1 pl.

Fridrich, C.J., Thompson, R.A., Slate, J.L., Berry, M.E., and Machette, M.N., 2012, Geologic map of the southern Funeral Mountains including nearby groundwater discharge sites in Death Valley National Park, California and Nevada: U.S. Geological Survey Scientific Investigations Map 3151, 20 p. pamphlet, 1 sheet, scale 1:50,000.

Goff, F., Wollenberg, H.A., Brookins, D.C., and Kistler, R.W., 1991, A Sr-isotopic comparison between thermal waters, rocks, and hydrothermal calcites, Long Valley caldera, California: Journal of Volcanology and Geothermal Research, v. 48, p. 265-281.

Gomez, J.B., Auque, L.F., Gimeno, M., and Acero, P., 2013, On the origin of Ash Meadows groundwater: Geochemical Modelling Group (GMG), Department of Earth Sciences, University of Zaragoza.

Grasso, D.N., 1996, Hydrology of modern and late Holocene lakes, Death Valley, California: U.S. Geological Survey Water-Resources Investigations Report 95-4237, 53 p.

Gross, M.R., and Louie, J.N., 1992, Geometry of normal faulting in Tecopa Valley, California from magnetic surveys: California Geology, v. 45, no. 4 (July/August), p. 110-117.

Hales, J.R., Jr., 1972, Surges of maritime tropical air northward over the Gulf of California: Monthly Weather Review, v. 100, p. 298-306.

Hales, J.R., Jr., 1974, Southwestern United States summer monsoon source - Gulf of Mexico or Pacific Ocean?: Journal of Applied Meteorology, v. 13, p. 331-342.

Harrill, J.R., 1986, Ground-water storage depletion in Pahrump Valley, Nevada-California, 1962-75: U.S. Geological Survey Water Supply Paper 2279, 53 p.

Harrill, J.R., Gates, J.S., and Thomas, J.M., 1988, Major ground-water flow systems in the Great Basin region of Nevada, Utah, and adjacent states: U.S. Geological Survey Hydrologic Atlas 694-C, 2 pls.

Harrill, J.R., and Prudic, D.E., 1998, Aquifer systems in the Great Basin region of Nevada, Utah, and adjacent statesSummary report: U.S. Geological Survey Professional Paper 1409-A, 66 p.
Hay, R.L., Pexton, R.E., Teague, T.T., and Kyser, T.K., 1986, Spring-related carbonate rocks, $\mathrm{Mg}$ clays, and associated minerals in Pliocene deposits of the Amargosa Desert, Nevada and California: Geological Society of America Bulletin, v. 97, p. 1488-1503.

Heilweil, V.M., and Brooks, L.E., eds., 2011, Conceptual model of the Great Basin carbonate and alluvial aquifer system: U.S. Geological Survey Scientific Investigations Report 2010-5193, 191 p.

Hem, J.D., 1992, Study and interpretation of the chemical characteristics of natural water: U.S. Geological Survey Water Supply Paper 2254, 264 p., https://pubs.usgs.gov/wsp/wsp2254/.

Hershey, R.L., 1989, Hydrogeology and the hydrogeochemistry of the Spring Mountains, Clark County, Nevada: Las Vegas, University of Nevada, M.S. Thesis, 248 p.

Hershey, R.L., and Acheampong, S.Y., 1997, Estimation of groundwater velocities from Yucca Flat to the Amargosa Desert using geochemistry and environmental isotopes: Desert Research Institute Technical Publication 126, University of Nevada, Las Vegas, 61 p., https://digitalscholarship.unlv.edu/water_pubs/126/.

Hershey, R.L., Mizell, S.A., and Earman, S., 2010, Chemical and physical characteristics of springs discharging from regional flow systems of the carbonate-rock province of the Great Basin, western United States: Hydrogeology Journal, v. 18 , no. 4 , p. 1007-1026.

Hershey, R.L., Thomas, J.M., Rose, T.P., Paces, J.B., Farnham, I.M., and Benedict, F.C.J., 2005, Evaluation of groundwater movement in the Frenchman Flat CAU using geochemical and isotopic analysis: Desert Research Institute Publication No. 45207, Las Vegas, NV, DOE/NV/13609-36, $65 \mathrm{p}$.

Hevesi, J.A., Flint, A.L., and Flint, L.E., 2003, Simulation of net infiltration and potential recharge using a distributed-parameter watershed model of the Death Valley Region, Nevada and California: U.S. Geological Survey Water-Resources Investigations Report 2003-4090, 161 p., accessed July 29, 2005, at https://water.usgs.gov/pubs/wri/wri034090/.

Hewitt, D.F., 1956, Geology and mineral resources of the Ivanpah quadrangle, California and Nevada: U.S. Geological Survey Professional Paper 275, 172 p.

Hillhouse, J.W., 1987, Late Tertiary and Quaternary geology of the Tecopa basin, southeastern California: U.S. Geological Survey Miscellaneous Investigations Map I-1728, scale 1:48,000, 16 p., 1 sheet. 
Huntington, J.L., and Allen, R.G., 2010, Evapotranspiration and net irrigation requirements for Nevada: Nevada Division of Water Resources, Carson City, NV, 133 p.

Huntington, J.L., Morton, C.G., and Bromley, M.R., 2016, Remote sensing of groundwater discharge from Chicago Valley, Shoshone area, and Tecopa/California Valley, California: Report prepared by Desert Research Institute for The Nature Conservancy, Reno, NV, 18 p., 2 appendixes.

Ingraham, N.L., Jacobson, R.L., Hess, J.W., and Lyles, B.F., 1990, Stable isotope study of precipitation and spring discharge on the Nevada Test Site: Desert Research Institute, Water Resources Center Publication no. 45078, $55 \mathrm{p}$.

Kilpatrick, F.A., and Schneider, V.R., 1983, Use of flumes in measuring discharge: U.S. Geological Survey Techniques of Water-Resources Investigations, book 3, chap. A14, 46 p., https://pubs.usgs.gov/twri/twri3-a14/.

Laczniak, R.J., Demeo, G.A., Reiner, S.R., Smith, J.L., and Nylund, W.E., 1999, Estimates of ground-water discharge as determined from measurements of evapotranspiration, Ash Meadows area, Nye County, Nevada: U.S. Geological Survey Water-Resources Investigations Report 99-4079, $70 \mathrm{p}$.

Laczniak, R.J., Smith, J.L.R., Elliott, P.E., DeMeo, G.A., Chatigny, M.A., and Roemer, G.J., 2001, Ground-water discharge determined from estimates of evapotranspiration, Death Valley regional flow system, Nevada and California: U.S. Geological Survey Water-Resources Investigations Report 2001-4195, 51 p., accessed September 22, 2004, at https:/water.usgs.gov/pubs/wri/wri014195/.

Larsen, D., 2008, Revisiting silicate authigenesis in the Pliocene-Pleistocene Lake Tecopa beds, southeastern California-Depositional and hydrological controls: Geosphere, v. 4, no. 3, p. 612-639, https://doi.org/10.1130/GES00152.1.

Larsen, D., Swihart, G.H., and Xiao, Y., 2001, Hydrochemistry and isotope composition of springs in the Tecopa basin, southeastern California, USA: Chemical Geology, v. 179, p. 17-35, https://doi.org/10.1016/S0009-2541(01)00313-8.

Louie, J.N., Cetintas, A., Chekuri, V., Corchuelo, W.D., Lei, Y., Li, L., Mekala, G., Ozalaybey, S., Raskulinecz, J., and Morrison, R.B., 2001, Geophysical constraints on the cessation of extension and thickness of basin fill in Tecopa Valley, California, in Wright, L.A., and Troxel, B.W., eds., Cenozoic basins of the Death Valley region: Geological Society of America Special Paper 333, accessed July 25, 2014, at http:/crack.seismo.unr.edu/ftp/pub/louie/papers/ tecopa/tecopa.html.
Malmberg, G.T., 1967, Hydrology of the valley-fill and carbonate-rock reservoirs, Pahrump Valley, NevadaCalifornia: U.S. Geological Survey Water Supply Paper 1832, $47 \mathrm{p}$.

Marshall, B.D., Moscati, R.J., and Patterson, G.L., 2012, Fluid geochemistry of Yucca Mountain and vicinity, in Stuckless, J.S., ed., Hydrology and geochemistry of Yucca Mountain and vicinity, southern Nevada and California: Geological Society of America Memoir, p. 143-218.

Mason, J.F., 1948, Geology of the Tecopa area: Geological Society of America Bulletin, v. 59, p. 333-352, 2 pls., scale 1:62,500.

Mifflin, M.D., 1988, Region 5, Great Basin, in Back, W., Rosenshein, J.S., and Seaber, P.R., eds., Hydrogeology, The geology of North America 0-2: Boulder, CO, Geological Society of America, p. 69-78.

Miller, R.R., Williams, J.D., and Williams, J.E., 1989, Extinctions of North American fishes during the past century: Fisheries v. 14 , no. 6, p. 22-38, https://doi.org/10.1577/1548-8446(1989)014\%3C0022:EO NAFD\%3E2.0.CO;2.

Miner, R.E., Nelson, S.T., Tingey, D.G., and Murrell, M.T., 2007, Using fossil spring deposits in the Death Valley region, USA to evaluate palaeoflowpaths: Journal of Quaternary Science, v. 22, no. 4, p. 373-386.

Morrison, R.B., 1999, Lake Tecopa: Quaternary geology of Tecopa Valley, California, a multimillion-year record and its relevance to the proposed nuclear waste repository at Yucca Mountain, Nevada, in Wright, L.A., and Troxel, B.W., eds., Cenozoic basins of the Death Valley region: Geological Society of America Special Paper 333, p. 301-344.

National Wild and Scenic Rivers System, 2015, Amargosa River, California: Web page accessed December 8, 2015, at https://www.rivers.gov/rivers/amargosa.php.

Nelson, S.T., Karlsson, H.R., Paces, J.B., Tingey, D.G., Ward, S., and Peters, M.T., 2001, Paleohydrologic record of spring deposits in and around Pleistocene pluvial Lake Tecopa, southeastern California: Geological Society of America Bulletin, v. 113, p. 659-670.

Oatfield, W.J., and Czarnecki, J.B., 1989, Hydrogeologic inferences from drillers' logs and from gravity and resistivity surveys in the Amargosa Desert, southern Nevada: U.S. Geological Survey Open-File Report 89-234, $29 \mathrm{p}$.

Oatfield, W.J., and Czarnecki, J.B., 1991, Hydrogeologic inferences from drillers' logs and from gravity and resistivity surveys in the Amargosa Desert, southern Nevada: Journal of Hydrology, v. 124, p. 131-158. 
Paces, J.B., Ludwig, K.R., Peterman, Z.E., and Neymark, L.A., 2002, 234U/238U evidence for local recharge and patterns of ground-water flow in the vicinity of Yucca Mountain, Nevada, USA: Applied Geochemistry, v. 17, p. 751-779.

Page, W.R., Dixon, G.L., Rowley, P.D, and Brickey, D.W., 2005, Geologic map of parts of the Colorado, White River, and Death Valley groundwater flow systems, Nevada, Utah, and Arizona: Nevada Bureau of Mines and Geology Map 150, scale 1:250,000.

Page, W.R., Lundstrom, S.C., Harris, A.G., Langenheim, V.E., Workman, J.B., Mahan, S.A., Paces, J.B., Dixon, G.L., Rowley, P.D., Burchfiel, B.C., Bell, J.W., and Smith, E.I., 2005, Geologic and geophysical maps of the Las Vegas 30' x 60' quadrangle, Clark and Nye Counties, Nevada, and Inyo County, California: U.S. Geological Survey Scientific Investigations Map SIM-2814, scale 1:100,000.

Page, W.R., Scheirer, D.S., Langenheim, V.E., and Berger, M.A., 2011, Revised geologic cross sections of parts of the Colorado, White River, and Death Valley regional groundwater flow systems, Nevada, Utah, and Arizona: U.S. Geological Survey Open-File Report 2006-1040, 25 p.

Parkhurst, D.L., and Appelo, C.A.J., 2013, Description of input and examples for PHREEQC version 3-A computer program for speciation, batch-reaction, one-dimensional transport, and inverse geochemical calculations: U.S. Geological Survey Techniques and Methods, book 6 , chap. A43, 497 p., accessed July 16, 2018, at https://pubs.usgs.gov/tm/06/a43/.

Pavlis, T.L., Rutkofske, J., Guerrero, F., and Serpa, L.F., 2014, Structural overprinting of Mesozoic thrust systems in eastern California and its importance to reconstruction of Neogene extension in the southern Basin and Range: Geosphere, v. 10, no. 4, p. 732-756.

Plume, R.W., 1996, Hydrogeologic framework of the Great Basin region of Nevada, Utah, and adjacent states: U.S. Geological Survey Professional Paper 1409-B, 64 p.

Ponce, D.A., and Blakely, R.J., 2001, Aeromagnetic map of the Death Valley ground-water model area, Nevada and California: U.S. Geological Survey Miscellaneous Field Studies Map MF-2381-D, scale 1:250,000, 4 p.

Ponce, D.A., Blakely, R.J., Morin, R.L., and Mankinen, E.A., 2001, Isostatic gravity map of the Death Valley groundwater model area, Nevada and California: U.S. Geological Survey Miscellaneous Field Studies Map MF-2381-C, scale $1: 250,000,5 \mathrm{p}$.
Potter, C.J., Sweetkind, D.S., Dickerson, R.P., and Killgore, M.L., 2002, Hydrostructural map of the Death Valley ground-water basin, Nevada and California: U.S. Geological Survey Miscellaneous Field Studies Map MF-2372, scale 1:350,000, 12 p., 2 pls.

Prave, A.R., and McMackin, M.R., 1999, Depositional framework of mid- to late Miocene strata, Dumont Hills and southern margin Kingston Range-Implications for the tectonostratigraphic evolution of the southern Death Valley region, in Wright, L.A., and Troxel, B.W., eds., Cenozoic basins of the Death Valley region: Geological Society of America Special Paper 333, p. 259-275.

Raines, G.L., Connors, K.A., Moyer, L.A., and Miller, R.J. [Geology compiled by J.H. Stewart and J.E. Carlson], 2003, Spatial digital database for the geologic map of Nevada: U.S. Geological Survey Open-File Report 2003-66, 32 p.

Rantz, S.E., and others, 1982, Measurement and computation of streamflow: Volume 1. Measurement of stage and discharge: U.S. Geological Survey Water Supply Paper 2175, 284 p.

Reiner, S.R., Laczniak, R.J., DeMeo, G.A., Smith, J.L., Elliott, P.E., Nylund, W.E., and Fridrich, C.J., 2002, Ground-water discharge determined from measurements of evapotranspiration, other available hydrologic components, and shallow water-level changes, Oasis Valley, Nye County, Nevada: U.S. Geological Survey Water-Resources Investigations Report 01-4239, 65 p.

Rhodes, J.A., 1969, History of hot water well near Tecopa, Inyo County, California: Sundry notices and report on wells (Notice of intention to abandon well), submitted to the U.S. Geological Survey Mining Branch, Salt Lake City, Utah, 5 p.

San Juan, C.A., Belcher, W.R., Laczniak, R.J., and Putnam, H.M., 2010, Hydrologic components for model development, in Belcher, W.R., and Sweetkind, D.S., eds., Death Valley regional groundwater flow system, Nevada and California-Hydrogeologic framework and transient groundwater flow model: U.S. Geological Survey Professional Paper 1711, p. 95-132.

Sass, J.H., Lachenbruch, A.H., Galanis, S.P., Morgan, P., Priest, S.S., Moses, T.H., and Munroe, R.J., 1994, Thermal regime of the southern Basin and Range Province: 1. Heat flow data from Arizona and the Mojave Desert of California and Nevada: Journal of Geophysical Research, v. 99, no. B11, p. 22093-22119.

Saucedo, G.J., Bedford, D.R., Raines, G.L., Miller, R.J., and Wentworth, C.M., 2000, GIS data for the geologic map of California: Sacramento, California Geological Survey CD 2000-07. 
Sauer, V.B., and Meyer, R.W., 1992, Determination of error in individual discharge measurements: U.S. Geological Survey Open-File Report 92-144, 21 p.

Scheirer, D.S., Sweetkind, D.S., and Miller, J.J., 2010, Multiple phases of basin formation along the Stateline fault system in the Pahrump and Mesquite Valleys, Nevada and California: Geosphere, v. 6, p. 93-129, 8 pls., https://doi.org/10.1130/GES00520.1.

Snow, J.K., and Wernicke, B.P., 2000, Cenozoic tectonism in the central Basin and Range-Magnitude, rate, and distribution of upper crustal strain: American Journal of Science, v. 300, p. 659-719.

Source Group, Inc., 2011, State of the basin report-Inyo and San Bernardino Counties, California and Nye County, Nevada: Report submitted to the Amargosa Conservancy, 65 p., 5 appendixes.

Starkey, H.C., and Blackmon, P.D., 1979, Clay mineralogy of Pleistocene Lake Tecopa, Inyo County, California: U.S. Geological Survey Professional Paper 1061, 34 p.

Steinkampf, W.C., and Werrell, W.L., 2001, Ground-water flow to Death Valley as inferred from the chemistry and geohydrology of selected springs in Death Valley National Park, California and Nevada: U.S. Geological Survey Water-Resources Investigations Report 98-4114, 37 p.

Stewart, J.H., 1988, Tectonics of the Walker Lane belt, western Great Basin Mesozoic and Cenozoic deformation in a zone of shear, in Ernst, W.G., ed., Metamorphism and crustal evolution of the western United States: Englewood Cliffs, N.J., Prentice-Hall, v. 7, p. 683-713.

Stewart, J.H., and Crowell, J.C., 1992, Strike-slip tectonics in the Cordilleran region, western United States, in Burchfiel, B.C., Lipman, P.W., and Zoback, M.L., eds., The Cordilleran orogen-Conterminous U.S.: Geological Society of America, Geology of North America, v. H-3, p. 609-628.

Sweetkind, D.S., Dickerson, R.P., Blakely, R.J., and Denning, P.D., 2001, Interpretive geologic cross sections for the Death Valley regional flow system and surrounding areas, Nevada and California: U.S. Geological Survey Miscellaneous Field Studies Map MF-2370, 32 p., 3 pls.

Sweetkind, D.S., Fridrich, C.J., and Taylor, E., 2001, Facies analysis of Tertiary basin-filling rocks of the Death Valley regional ground-water system and surrounding areas, Nevada and California: U.S. Geological Survey Open-File Report 2001-400, 55 p.
Sweetkind, D.S., Taylor, E., and Putnam, H., 2003, Stratigraphic inferences derived from borehole data of Tertiary basin-filling rocks of the Pahrump Valley basin, Nevada and California: U.S. Geological Survey Open-File Report 2003-051, 30 p.

Taylor, E.M., and Sweetkind, D.S., 2014, Three-dimensional geologic mapping of Cenozoic basin fill, Amargosa Desert basin, Nevada and California: U.S. Geological Survey Scientific Investigations Report 2014-5003, 40 p., 2 appendixes.

Thomas, J.M., Benedict, F.C., Rose, T.P., Hershey, R.L., Paces, J.B., Peterman, Z.E., Farnham, K.H., Johannesson, A.K., Singh, A.K., Stetzenbach, K.J., Hudson, G.B., Kenneally, J.M., Eaton, G.F., and Smith, D.K., 2002, Geochemical and isotopic interpretations of groundwater flow in the Oasis Valley flow system, southern Nevada: U.S. Department of Energy, DOE/ NV/11508-56, Publication 45190, 113 p.

Thomas, J.M., Welch, A.H., and Dettinger, M.D., 1996, Geochemistry and isotope hydrology of the representative aquifers in the Great Basin region of Nevada, Utah, and adjacent states: U.S. Geological Survey Professional Paper 1409-C, 100 p., 2 pls.

Toccalino, P.L., Norman, J.E., and Hitt, K.J., 2010, Quality of source water from public-supply wells in the United States, 1993-2007: U.S. Geological Survey Scientific Investigations Report 2010-5024, 209 p.

Topping, D.J., 1993, Paleogeographic reconstruction of the Death Valley extended region-Evidence from Miocene large rock-avalanche deposits in the Amargosa Chaos basin, California: Geological Society of America Bulletin, v. 105, p. 1190-1213.

U.S. Environmental Protection Agency, 2014, Drinking water contaminants - National Primary Drinking Water Regulations and National Secondary Drinking Water Regulations: Web page accessed October 17, 2014, at https://water.epa.gov/drink/contaminants/index.cfm.

U.S. Geological Survey, 2004, Policy on the use of the FlowTracker for discharge measurements: U.S. Geological Survey Office of Surface Water Technical Memorandum 2004.04, 9 p., accessed July 16, 2018, at https:/hydroacoustics.usgs.gov/memos/OSW2004-04.pdf.

U.S. Geological Survey, 2014, USGS water data for the Nation: U.S. Geological Survey National Water Information System database, accessed September 30, 2014, at https://waterdata.usgs.gov/nwis. 
U.S. Geological Survey, variously dated, National field manual for the collection of water-quality data: U.S. Geological Survey Techniques of Water-Resources Investigations, book 9, chaps. A1-A9 [variously paged], https://water.usgs.gov/owq/FieldManual/.

Walker, G.E., and Eakin, T.E., 1963, Geology and ground water of Amargosa Desert, Nevada-California: Nevada Department of Conservation and Natural Resources, Ground-Water Resources-Reconnaissance Series Report 14, $44 \mathrm{p}$.

Winograd, I.J., Fridrich, C.J., Sweetkind, D., Belcher, W.R., and Thomas, J.M., 2005, Comment on "Testing the interbasin flow hypothesis at Death Valley, California": EOS, v. 86, no. 32, p. 295-296.

Winograd, I.J., and Thordarson, W., 1975, Hydrogeologic and hydrogeochemical framework, south-central Great Basin, Nevada-California, with special reference to the Nevada Test Site: U.S. Geological Survey Professional Paper $712-\mathrm{C}, 125 \mathrm{p}$.

Winter, T.C., Harvey, J.W., Franke, O.L., and Alley, W.M., 1998, Ground water and surface water-A single resource: U.S. Geological Survey Circular 1139, 79 p.

Wood, D.B., 2009, Digitally available interval-specific rocksample data compiled from historical records, Nevada Test Site and vicinity, Nye County, Nevada (ver. 2.0): U.S. Geological Survey Data Series 297, 56 p., 6 digital appendixes.

Workman, J.B., Menges, C.M., Page, W.R., Ekren, E.B., Rowley, P.D., and Dixon, G.L., 2002, Tectonic map of the Death Valley ground-water model area, Nevada and California: U.S. Geological Survey Miscellaneous Field Studies Map MF-2381-B, scale 1:350,000, 56 p.
Workman, J.B., Menges, C.M., Page, W.R., Taylor, E.M., Ekren, E.B., Rowley, P.D., Dixon, G.L., Thompson, R.A., and Wright, L.A., 2002, Geologic map of the Death Valley ground-water model area, Nevada and California: U.S. Geological Survey Miscellaneous Field Studies Map MF-2381-A, scale 1:250,000, 26 p.

Wright, L.A., Greene, R.C., Cemen, I., Johnson, F.C., and Prave, A.R., 1999, Tectonostratigraphic development of the Miocene-Pliocene Furnace Creek Basin and related features, Death Valley region, California, in Wright, L.A., and Troxel, B.W., eds., Cenozoic basins of the Death Valley region: Geological Society of America Special Paper 333, p. 87-114.

Wright, L.A., Thompson, R.A., Troxel, B.W., Pavlis, T.L., DeWitt, E., Otton, J.K., Ellis, M.A., Miller, M.G., and Serpa, L.F., 1991, Cenozoic magmatic and tectonic evolution of the east-central Death Valley region, California, in Walawender, M.J., and Hanan, B.B., eds., Geological excursions in southern California and Mexico: Geological Society of America Annual Meeting Guidebook, p. 93-127.

Wright, L.A., and Troxel, B.W., 1984, Geology of the northern half of the Confidence Hills 15-minute quadrangle, Death Valley region, eastern California-Amargosa chaos: California Division of Mines and Geology Map Sheet 34.

Zdon, A., Davisson, M.L., and Love, A.H., 2015, Testing the established hydrogeologic model of source water to the Amargosa River basin, Inyo and San Bernardino Counties, California: Environmental Forensics, v. 16, no. 4, p. 344-355, https://doi.org/10.1080/15275922.2015. 1091406. 
Table 9. Water chemistry of selected samples from the Lower Amargosa Valley and extra-basin contributing areas, California and Nevada.

[All significant figures reflective of what was reported by sources. Data from the U.S. Geological Survey (USGS) from the USGS National Water Information System (NWIS) database. All analyses are assumed to be reported filtered values. Abbreviations: BLS, below land surface; CA, California; E, estimated value; $\mathrm{HCO}_{3}$, bicarbonate; IC, inductively coupled; ICP, inductively coupled plasma; ICP-MS, inductively coupled plasma-mass spectrometry; ID, identification; M, detected but not quantified; mg/L, milligram per liter; mm/dd/yyyy, month/day/year; NAD83, North American Datum of 1983; NA, not applicable; ND, not detected; pMC, percent modern carbon; R, radiochemical non-detect; TU, tritium unit; UTM, Universal Transverse Mercator; $\mu \mathrm{g} / \mathrm{L}$, microgram per liter; $\mu \mathrm{S} / \mathrm{cm}$, microsiemens per centimeter; ${ }^{\circ} \mathrm{C}$, degrees Celsius; \%o, per mil; $\delta$, delta; $<$, less than; - , no data available]

\begin{tabular}{|c|c|c|c|c|c|c|c|c|}
\hline Site name & $\begin{array}{l}\text { Source } \\
\text { of data }\end{array}$ & $\begin{array}{c}\text { Sample } \\
\text { collection date } \\
\text { (mm/dd/yyyy) }\end{array}$ & $\begin{array}{l}\text { USGS site ID } \\
\text { (if applicable) }\end{array}$ & $\begin{array}{c}\text { Water } \\
\text { temperature } \\
\left({ }^{\circ} \mathrm{C}\right)\end{array}$ & $\begin{array}{c}\text { Specific } \\
\text { conductance } \\
(\mu \mathrm{S} / \mathrm{cm} \text { at } \\
\left.25^{\circ} \mathrm{C}\right)\end{array}$ & $\begin{array}{c}\text { Dissolved } \\
\text { oxygen } \\
\text { (mg/L) }\end{array}$ & $\begin{array}{c}\text { Total } \\
\text { dissolved } \\
\text { solids } \\
\text { (mg/L) }\end{array}$ & pH \\
\hline Amargosa Canyon Spring 1 & Source Group, Inc., 2011 & $04 / 25 / 2011$ & - & 23.2 & 1,029 & 8.62 & 650 & 7.93 \\
\hline Amargosa Canyon Spring 1 & Source Group, Inc., 2011 & $12 / 22 / 2011$ & - & 18.7 & 1,009 & 7.96 & 656 & 8.22 \\
\hline Amargosa Canyon Spring 4 & Source Group, Inc., 2011 & $04 / 25 / 2011$ & - & 26.1 & 1,240 & 8.63 & 780 & 8.34 \\
\hline Amargosa Canyon Spring 4 & Source Group, Inc., 2011 & $12 / 22 / 2011$ & - & 26.2 & 1,273 & 7.34 & 828 & 8.33 \\
\hline Willow Spring & Larsen and others, 2001 & $01 / 04 / 1999$ & 10251335 & 18.1 & 1,160 & - & - & 7.0 \\
\hline Willow Spring & Paces and others, 2002 & 03/11/1993 & 10251335 & - & - & - & - & - \\
\hline Willow Spring & Source Group, Inc., 2011 & $04 / 26 / 2011$ & 10251335 & 23.7 & - & - & 740 & 8.26 \\
\hline Willow Spring & Source Group, Inc., 2011 & $09 / 23 / 2011$ & 10251335 & 24.2 & 1,028 & 8.08 & 668 & 8.14 \\
\hline Amargosa River (AR3314; seepage run) & USGS (NWIS) & $03 / 27 / 2014$ & 355427116153201 & 10 & 13,000 & 9.0 & - & 7.5 \\
\hline Amargosa River 2 & Source Group, Inc., 2011 & $11 / 17 / 2010$ & - & 21.4 & 4,295 & 8.64 & 2,793 & 8.89 \\
\hline Amargosa River 2 & Source Group, Inc., 2011 & $05 / 02 / 2011$ & - & 21.4 & - & - & 2,800 & 8.89 \\
\hline Amargosa River at Tecopa, CA & USGS (NWIS) & $03 / 15 / 2005$ & 10251300 & 14 & 6,620 & 10.4 & - & 9.1 \\
\hline Amargosa River at Tecopa, CA & USGS (NWIS) & $03 / 27 / 2014$ & 10251300 & 12.8 & 8,190 & 14 & - & 8.1 \\
\hline Amargosa River in Upper Canyon near Tecopa, CA & USGS (NWIS) & $03 / 15 / 2005$ & 354932116131201 & 20.5 & 3,260 & 10 & - & 8.7 \\
\hline Crystal Pool & Dudley and Larsen, 1976 & $11 / 1966$ & 354932116131201 & 33 & - & - & 432 & - \\
\hline Crystal Pool & Gomez and others, 2013 & - & 354932116131201 & 30.87 & 708.44 & - & - & 7.32 \\
\hline Crystal Pool & Hershey and others, 2010 & 03/17/1992 & 354932116131201 & 31 & 700 & - & 597 & 7.3 \\
\hline Crystal Pool & USGS (NWIS) & 05/07/1997 & 354932116131201 & 30.5 & 737 & 3.7 & 433 & 7.4 \\
\hline Devils Hole (AM-4) & Thomas and others, 1996 & - & 362532116172700 & 33 & 690 & - & - & - \\
\hline Devils Hole (AM-4) & Gomez and others, 2013 & - & 362532116172700 & 32.96 & 684.40 & - & - & 7.43 \\
\hline Devils Hole (AM-4) & Hershey and others, 2010 & 07/09/1992 & 362532116172700 & 34 & 692 & - & 561 & 7.2 \\
\hline Devils Hole (AM-4) & USGS (NWIS) & $06 / 03 / 1984$ & 362532116172700 & 34 & 662 & 2.8 & - & 7.4 \\
\hline Devils Hole (AM-4) & USGS (NWIS) & $06 / 03 / 1984$ & 362532116172700 & 34 & 663 & 2.8 & - & 7.4 \\
\hline Devils Hole (AM-4) & USGS (NWIS) & 03/09/1985 & 362532116172700 & 31.6 & - & - & - & 7.4 \\
\hline Devils Hole (AM-4) & USGS (NWIS) & 03/09/1985 & 362532116172700 & 31.7 & - & - & - & 7.4 \\
\hline Devils Hole (AM-4) & USGS (NWIS) & 03/10/1985 & 362532116172700 & 32 & - & - & - & 7.4 \\
\hline Devils Hole (AM-4) & USGS (NWIS) & $05 / 05 / 1986$ & 362532116172700 & - & - & - & - & - \\
\hline
\end{tabular}


Table 9. Water chemistry of selected samples from the Lower Amargosa Valley and extra-basin contributing areas, California and Nevada.-Continued

[All significant figures reflective of what was reported by sources. Data from the U.S. Geological Survey (USGS) from the USGS National Water Information System (NWIS) database. All analyses are assumed to be reported filtered values. Abbreviations: BLS, below land surface; CA, California; E, estimated value; $\mathrm{HCO}_{3}$, bicarbonate; IC, inductively coupled; ICP, inductively coupled plasma;

ICP-MS, inductively coupled plasma-mass spectrometry; ID, identification; M, detected but not quantified; mg/L, milligram per liter; mm/dd/yyyy, month/day/year; NAD83, North American Datum of 1983; $\mathrm{NA}$, not applicable; ND, not detected; pMC, percent modern carbon; R, radiochemical non-detect; TU, tritium unit; UTM, Universal Transverse Mercator; $\mu \mathrm{g} / \mathrm{L}$, microgram per liter; $\mu \mathrm{S} / \mathrm{cm}$, microsiemens per centimeter; ${ }^{\circ} \mathrm{C}$, degrees Celsius; \%o, per mil; $\delta$, delta; $<$, less than; - , no data available]

\begin{tabular}{|c|c|c|c|c|c|c|c|c|}
\hline Site name & $\begin{array}{l}\text { Source } \\
\text { of data }\end{array}$ & $\begin{array}{c}\text { Sample } \\
\text { collection date } \\
\text { (mm/dd/yyyy) }\end{array}$ & $\begin{array}{l}\text { USGS site ID } \\
\text { (if applicable) }\end{array}$ & $\begin{array}{c}\text { Water } \\
\text { temperature } \\
\left({ }^{\circ} \mathrm{C}\right)\end{array}$ & $\begin{array}{c}\text { Specific } \\
\text { conductance } \\
\text { ( } \mu \mathrm{S} / \mathrm{cm} \text { at } \\
\left.25^{\circ} \mathrm{C}\right)\end{array}$ & $\begin{array}{l}\text { Dissolved } \\
\text { oxygen } \\
\text { (mg/L) }\end{array}$ & $\begin{array}{c}\text { Total } \\
\text { dissolved } \\
\text { solids } \\
\text { (mg/L) }\end{array}$ & $\mathrm{pH}$ \\
\hline Devils Hole (AM-4) & USGS (NWIS) & $05 / 05 / 1986$ & 362532116172700 & - & - & - & - & - \\
\hline Devils Hole (AM-4) & USGS (NWIS) & $11 / 16 / 1986$ & 362532116172700 & - & - & - & - & - \\
\hline Devils Hole (AM-4) & USGS (NWIS) & $11 / 16 / 1986$ & 362532116172700 & - & - & - & - & - \\
\hline Devils Hole (AM-4) & USGS (NWIS) & $06 / 22 / 1987$ & 362532116172700 & - & - & - & - & - \\
\hline Devils Hole (AM-4) & USGS (NWIS) & $06 / 22 / 1987$ & 362532116172700 & - & - & - & - & - \\
\hline Devils Hole (AM-4) & USGS (NWIS) & $03 / 16 / 1988$ & 362532116172700 & - & - & - & - & - \\
\hline Devils Hole (AM-4) & USGS (NWIS) & 03/16/1988 & 362532116172700 & - & - & - & - & - \\
\hline Devils Hole (AM-4) & USGS (NWIS) & $12 / 07 / 1988$ & 362532116172700 & 33.2 & - & - & - & - \\
\hline Devils Hole (AM-4) & USGS (NWIS) & $12 / 07 / 1988$ & 362532116172700 & 34 & - & - & - & - \\
\hline Devils Hole (AM-4) & USGS (NWIS) & $06 / 21 / 1989$ & 362532116172700 & 33 & 679 & 2.5 & - & - \\
\hline Devils Hole (AM-4) & USGS (NWIS) & $06 / 21 / 1989$ & 362532116172700 & - & - & - & - & - \\
\hline Devils Hole (AM-4) & USGS (NWIS) & $06 / 25 / 1990$ & 362532116172700 & - & 695 & - & - & 7.5 \\
\hline Devils Hole (AM-4) & USGS (NWIS) & $06 / 25 / 1990$ & 362532116172700 & 34 & 698 & - & - & 7.5 \\
\hline Devils Hole (AM-4) & USGS (NWIS) & $08 / 22 / 1990$ & 362532116172700 & 33 & 707 & - & 411 & 7.5 \\
\hline Devils Hole (AM-4) & USGS (NWIS) & 08/15/1991 & 362532116172700 & 34.6 & 687 & - & - & 7.3 \\
\hline Devils Hole (AM-4) & USGS (NWIS) & 08/27/1991 & 362532116172700 & 35 & 685 & - & 408 & 7.4 \\
\hline Devils Hole (AM-4) & USGS (NWIS) & 08/19/1992 & 362532116172700 & 34 & 706 & - & 406 & 7.4 \\
\hline Devils Hole (AM-4) & USGS (NWIS) & 08/18/1999 & 362532116172700 & 33 & 709 & 2.9 & 418 & 7.3 \\
\hline Devils Hole (AM-4) & USGS (NWIS) & 08/18/1999 & 362532116172700 & 33.5 & 690 & 3 & - & 7.6 \\
\hline Devils Hole (AM-4) & USGS (NWIS) & 08/18/1999 & 362532116172700 & - & - & - & - & - \\
\hline Devils Hole (AM-4) & USGS (NWIS) & 09/23/1999 & 362532116172700 & 32 & - & - & - & - \\
\hline Devils Hole (AM-4) & USGS (NWIS) & $09 / 10 / 2003$ & 362532116172700 & 33.5 & 677 & 2.6 & - & 7.4 \\
\hline Devils Hole (AM-4) & USGS (NWIS) & $09 / 10 / 2003$ & 362532116172700 & - & - & - & - & - \\
\hline Devils Hole (AM-4) & USGS (NWIS) & $09 / 27 / 2005$ & 362532116172700 & 33 & 704 & 2.9 & - & 6.9 \\
\hline Devils Hole (AM-4) & USGS (NWIS) & $09 / 27 / 2005$ & 362532116172700 & - & - & - & - & - \\
\hline
\end{tabular}


[All significant figures reflective of what was reported by sources. Data from the U.S. Geological Survey (USGS) from the USGS National Water Information System (NWIS) database. All analyses are assumed to be reported filtered values. Abbreviations: BLS, below land surface; CA, California; E, estimated value; $\mathrm{HCO}_{3}$, bicarbonate; IC, inductively coupled; ICP, inductively coupled plasma; ICP-MS, inductively coupled plasma-mass spectrometry; ID, identification; M, detected but not quantified; mg/L, milligram per liter; mm/dd/yyyy, month/day/year; NAD83, North American Datum of 1983; NA, not applicable; ND, not detected; pMC, percent modern carbon; R, radiochemical non-detect; TU, tritium unit; UTM, Universal Transverse Mercator; $\mu \mathrm{g} / \mathrm{L}$, microgram per liter; $\mu \mathrm{S} / \mathrm{cm}$, microsiemens pe centimeter; ${ }^{\circ} \mathrm{C}$, degrees Celsius; \%o, per mil; $\delta$, delta; $<$, less than; - , no data available]

\begin{tabular}{|c|c|c|c|c|c|c|c|c|}
\hline Site name & $\begin{array}{l}\text { Source } \\
\text { of data }\end{array}$ & $\begin{array}{c}\text { Sample } \\
\text { collection date } \\
\text { (mm/dd/yyyy) }\end{array}$ & $\begin{array}{l}\text { USGS site ID } \\
\text { (if applicable) }\end{array}$ & $\begin{array}{c}\text { Water } \\
\text { temperature } \\
\left({ }^{\circ} \mathrm{C}\right)\end{array}$ & $\begin{array}{c}\text { Specific } \\
\text { conductance } \\
\text { ( } \mu \mathrm{S} / \mathrm{cm} \text { at } \\
25^{\circ} \mathrm{C} \text { ) }\end{array}$ & $\begin{array}{c}\text { Dissolved } \\
\text { oxygen } \\
\text { (mg/L) }\end{array}$ & $\begin{array}{c}\text { Total } \\
\text { dissolved } \\
\text { solids } \\
\text { (mg/L) }\end{array}$ & $\mathrm{pH}$ \\
\hline Fairbanks Spring & Dudley and Larsen, 1976 & $11 / 1966$ & 362924116203001 & 27 & - & - & 424 & - \\
\hline Fairbanks Spring & Gomez and others, 2013 & - & 362924116203001 & 27.72 & 690.0 & - & - & 7.33 \\
\hline Fairbanks Spring & Hershey and others, 2010 & 03/17/1992 & 362924116203001 & 27 & 661 & - & 582 & 7.5 \\
\hline Fairbanks Spring & Thomas and others, 1996 & - & 362924116203001 & 27 & 690 & - & - & - \\
\hline Fairbanks Spring & USGS (NWIS) & 05/06/1997 & 362924116203001 & 27.0 & 705 & 3.2 & - & 7.4 \\
\hline Five Springs well (AM-2) & Gomez and others, 2013 & - & 362755116190401 & 33.92 & 695.33 & - & - & 7.33 \\
\hline Five Springs well (AM-2) & Source Group, Inc., 2011 & 05/01/2011 & 362755116190401 & 34.4 & 693 & 4.44 & 454 & 7.60 \\
\hline Five Springs well (AM-2) & USGS (NWIS) & 08/24/1990 & 362755116190401 & 34.0 & 708 & - & - & 7.70 \\
\hline Five Springs well (AM-2) & USGS (NWIS) & 04/28/1992 & 362755116190401 & 32.5 & 697 & - & - & 7.8 \\
\hline Five Springs well (AM-2) & USGS (NWIS) & $10 / 18 / 1994$ & 362755116190401 & 33.0 & 430 & - & 337 & 7.6 \\
\hline Five Springs well (AM-2) & USGS (NWIS) & 09/22/1996 & 362755116190401 & 31.7 & 482 & 0.9 & - & 9.1 \\
\hline Hog Farm well & Zdon and Associates, 2014 & $04 / 25 / 2013$ & - & - & 1,500 & - & 860 & - \\
\hline Point of Rocks Spring & Gomez and others, 2013 & - & 362410116161002 & 30.33 & 665.0 & - & - & 7.50 \\
\hline Point of Rocks Spring & Hershey and others, 2010 & - & 362410116161002 & 32 & - & - & 582 & 7.2 \\
\hline Tule Spring & Hershey, 1989 & 06/30/1985 & 354901116031701 & - & - & - & - & - \\
\hline Tule Spring & USGS (NWIS) & $01 / 16 / 2013$ & 354901116031701 & 8.9 & 820 & 1.9 & 537 & 7.4 \\
\hline Resting Spring & Paces and others, 2002 & 03/11/1993 & - & - & - & - & - & - \\
\hline Resting Spring & Source Group, Inc., 2011 & $01 / 23 / 2011$ & - & 26.8 & 923 & 5.62 & 600 & 8.36 \\
\hline Resting Spring & Source Group, Inc., 2011 & $05 / 25 / 2011$ & - & 26.8 & - & - & 580 & 8.36 \\
\hline Twelvemile Spring & Zdon and Associates, 2014 & $04 / 25 / 2013$ & 360118116091601 & - & 770 & - & 430 & - \\
\hline Twelvemile Spring & Source Group, Inc., 2011 & $11 / 14 / 2010$ & 360118116091601 & 19 & 800 & 1.38 & 520 & 7.7 \\
\hline Twelvemile Spring & USGS (NWIS) & $03 / 21 / 2013$ & 360118116091601 & E22.0 & - & - & 476 & E7.6 \\
\hline Salsberry Spring & Paces and others, 2002 & 06/17/1998 & 355554116250701 & - & - & - & - & - \\
\hline Salsberry Spring & USGS (NWIS) & $03 / 11 / 2013$ & 355554116250701 & E11.5 & 311 & - & 291 & 8.3 \\
\hline Crystal Spring & Drakos and Hodgins, 2013 & 03/14/2012 & - & 10.7 & 479 & - & 290 & 6.86 \\
\hline Crystal Spring & Paces and others, 2002 & 02/05/1990 & - & - & - & - & - & - \\
\hline Crystal Spring & Zdon and Associates, 2014 & $04 / 26 / 2011$ & - & 21.2 & 610 & 5.73 & 397 & 7.52 \\
\hline
\end{tabular}


Table 9. Water chemistry of selected samples from the Lower Amargosa Valley and extra-basin contributing areas, California and Nevada.-Continued

[All significant figures reflective of what was reported by sources. Data from the U.S. Geological Survey (USGS) from the USGS National Water Information System (NWIS) database. All analyses are assumed to be reported filtered values. Abbreviations: BLS, below land surface; CA, California; E, estimated value; $\mathrm{HCO}_{3}$, bicarbonate; IC, inductively coupled; ICP, inductively coupled plasma;

ICP-MS, inductively coupled plasma-mass spectrometry; ID, identification; M, detected but not quantified; mg/L, milligram per liter; mm/dd/yyyy, month/day/year; NAD83, North American Datum of 1983; $\mathrm{NA}$, not applicable; ND, not detected; pMC, percent modern carbon; R, radiochemical non-detect; TU, tritium unit; UTM, Universal Transverse Mercator; $\mu \mathrm{g} / \mathrm{L}$, microgram per liter; $\mu \mathrm{S} / \mathrm{cm}$, microsiemens per centimeter; ${ }^{\circ} \mathrm{C}$, degrees Celsius; \%o, per mil; $\delta$, delta; $<$, less than; - , no data available]

\begin{tabular}{|c|c|c|c|c|c|c|c|c|}
\hline Site name & $\begin{array}{l}\text { Source } \\
\text { of data }\end{array}$ & $\begin{array}{c}\text { Sample } \\
\text { collection date } \\
\text { (mm/dd/yyyy) }\end{array}$ & $\begin{array}{l}\text { USGS site ID } \\
\text { (if applicable) }\end{array}$ & $\begin{array}{c}\text { Water } \\
\text { temperature } \\
\left({ }^{\circ} \mathrm{C}\right)\end{array}$ & $\begin{array}{c}\text { Specific } \\
\text { conductance } \\
\text { ( } \mu \mathrm{S} / \mathrm{cm} \text { at } \\
\left.25^{\circ} \mathrm{C}\right)\end{array}$ & $\begin{array}{l}\text { Dissolved } \\
\text { oxygen } \\
\text { (mg/L) }\end{array}$ & $\begin{array}{c}\text { Total } \\
\text { dissolved } \\
\text { solids } \\
\text { (mg/L) }\end{array}$ & pH \\
\hline Crystal Spring & Zdon and Associates, 2014 & $04 / 27 / 2011$ & - & 21.1 & - & - & 350 & 7.45 \\
\hline Crystal Spring & USGS (NWIS) & 08/10/1994 & - & - & 238 & - & 188 & 7.50 \\
\hline Crystal Spring & USGS (NWIS) & 08/10/1994 & - & 31 & 530 & - & 308 & 7.60 \\
\hline Crystal Spring & USGS (NWIS) & 09/23/1996 & - & - & - & - & - & - \\
\hline Crystal Spring & USGS (NWIS) & $07 / 27 / 1998$ & - & - & 348 & 2 & - & - \\
\hline Nevada National Security Site well & Gomez and others, 2013 & - & - & 41.35 & 485.17 & - & - & 7.27 \\
\hline 162 S20 E 5323 ABAD1 U19 & USGS (NWIS) & $11 / 07 / 2013$ & 361200115580001 & 23.6 & 406 & 5.9 & - & 7.1 \\
\hline Hidden Hills Ranch well & Hershey, 1989 & 07/30/1987 & - & 24 & 476 & - & 298.0 & 7.22 \\
\hline Jeep Trail well & Drakos and Hodgins, 2013 & $03 / 16 / 2012$ & - & 22.8 & 351 & 7.07 & 220 & 7.82 \\
\hline NC-GWE-PV-04 & USGS (NWIS) & $06 / 27 / 2012$ & 360952116021501 & 25.6 & 403 & 6.4 & - & 7.5 \\
\hline NC-GWE-PV-04 & USGS (NWIS) & $10 / 15 / 2012$ & 360952116021501 & 21.5 & 529 & 6.8 & 246 & 7.9 \\
\hline Stump Spring well & Drakos and Hodgins, 2013 & $02 / 28 / 2012$ & - & 18.6 & 325 & 5.71 & 182 & 7.3 \\
\hline Stump Spring well & USGS (NWIS) & $06 / 22 / 2009$ & - & 20.7 & 302 & 6.2 & 213 & 7.7 \\
\hline Stump Spring well & USGS (NWIS) & $05 / 20 / 2010$ & - & 23.7 & 318 & 5.5 & - & 7.5 \\
\hline Black Mountain precipitation & USGS (NWIS) & $03 / 11 / 2013$ & 355243116275301 & - & - & - & - & - \\
\hline Kingston Range precipitation & USGS (NWIS) & $01 / 16 / 2013$ & 354719115563601 & - & - & - & - & - \\
\hline Mt Charleston precipitation & USGS (NWIS) & $05 / 23 / 2013$ & - & - & - & - & - & - \\
\hline Nopah Range precipitation & USGS (NWIS) & 03/19/2013 & 355258116032901 & - & - & - & - & - \\
\hline Borax Spring & Larsen and others, 2001 & 01/03/1999 & 355317116152901 & 29.5 & ND & - & - & 10.5 \\
\hline Borax Spring & Source Group, Inc., 2011 & $04 / 27 / 2011$ & 355317116152901 & 30.5 & - & - & 2,100 & 9.91 \\
\hline Borax Spring & Source Group, Inc., 2011 & $09 / 21 / 2011$ & 355317116152901 & 30.5 & 2,981 & 1.71 & 1,938 & 10.14 \\
\hline Chappo Spring & Paces and others, 2002 & 03/12/1993 & - & - & - & - & - & - \\
\hline Chappo Spring & Source Group, Inc., 2011 & $05 / 01 / 2011$ & - & 23.2 & 755 & 3.81 & 470 & 7.81 \\
\hline Chappo Spring & Larsen and others, 2001 & 01/05/1999 & - & 28.6 & 730 & - & - & 6.8 \\
\hline Cynthia's well & Zdon and Associates, 2014 & $04 / 25 / 2013$ & - & - & - & - & - & 7.90 \\
\hline Cynthia's well & Source Group, Inc., 2011 & 05/11/2011 & - & 20.6 & - & - & 790 & 8.50 \\
\hline Cynthia's well & Zdon and Associates, 2014 & $01 / 16 / 2011$ & - & 20.6 & 898 & 7.10 & 584 & 8.50 \\
\hline
\end{tabular}


[All significant figures reflective of what was reported by sources. Data from the U.S. Geological Survey (USGS) from the USGS National Water Information System (NWIS) database. All analyses are assumed to be reported filtered values. Abbreviations: BLS, below land surface; CA, California; E, estimated value; $\mathrm{HCO}_{3}$, bicarbonate; IC, inductively coupled; ICP, inductively coupled plasma; ICP-MS, inductively coupled plasma-mass spectrometry; ID, identification; M, detected but not quantified; mg/L, milligram per liter; mm/dd/yyyy, month/day/year; NAD83, North American Datum of 1983; NA, not applicable; ND, not detected; pMC, percent modern carbon; R, radiochemical non-detect; TU, tritium unit; UTM, Universal Transverse Mercator; $\mu \mathrm{g} / \mathrm{L}$, microgram per liter; $\mu \mathrm{S} / \mathrm{cm}$, microsiemens pe centimeter; ${ }^{\circ} \mathrm{C}$, degrees Celsius; \%o, per mil; $\delta$, delta; $<$, less than; - , no data available]

\begin{tabular}{|c|c|c|c|c|c|c|c|c|}
\hline Site name & $\begin{array}{l}\text { Source } \\
\text { of data }\end{array}$ & $\begin{array}{c}\text { Sample } \\
\text { collection date } \\
\text { (mm/dd/yyyy) }\end{array}$ & $\begin{array}{l}\text { USGS site ID } \\
\text { (if applicable) }\end{array}$ & $\begin{array}{c}\text { Water } \\
\text { temperature } \\
\left({ }^{\circ} \mathrm{C}\right)\end{array}$ & $\begin{array}{c}\text { Specific } \\
\text { conductance } \\
\text { ( } \mu \mathrm{S} / \mathrm{cm} \text { at } \\
\left.25^{\circ} \mathrm{C}\right)\end{array}$ & $\begin{array}{c}\text { Dissolved } \\
\text { oxygen } \\
\text { (mg/L) }\end{array}$ & $\begin{array}{c}\text { Total } \\
\text { dissolved } \\
\text { solids } \\
\text { (mg/L) }\end{array}$ & $\mathrm{pH}$ \\
\hline Shoshone Spring & Larsen and others, 2001 & $01 / 16 / 1962$ & 355846116161901 & - & - & - & - & 8 \\
\hline Shoshone Spring & Larsen and others, 2001 & $02 / 27 / 1976$ & 355846116161901 & - & - & - & - & 7.7 \\
\hline Shoshone Spring & Larsen and others, 2001 & 01/06/1997 & 355846116161901 & 32.2 & 1,520 & - & - & 7.4 \\
\hline Shoshone Spring & Source Group, Inc., 2011 & $01 / 23 / 2011$ & 355846116161901 & 33.5 & 1,624 & 3.75 & 1,056 & 7.79 \\
\hline Shoshone Spring & Source Group, Inc., 2011 & $04 / 27 / 2011$ & 355846116161901 & 33.5 & - & - & 920 & 7.79 \\
\hline Shoshone Spring & USGS (NWIS) & 03/10/1998 & 355846116161901 & 33.7 & 1,580 & - & - & - \\
\hline Thom Spring & Source Group, Inc., 2011 & $11 / 11 / 2010$ & - & 38.9 & 1,571 & 2.77 & 1,021 & 7.63 \\
\hline Thom Spring & Source Group, Inc., 2011 & $04 / 27 / 2011$ & - & 24.8 & - & - & 990 & 7.63 \\
\hline Wild Bath Spring & USGS (NWIS) & 06/10/1998 & 355222116130601 & 42.5 & 1,150 & - & - & - \\
\hline Wild Bath Spring & Source Group, Inc., 2011 & $04 / 27 / 2011$ & 355222116130601 & 29.9 & - & - & 1,000 & 7.90 \\
\hline Wild Bath Spring & Source Group, Inc., 2011 & $09 / 21 / 2011$ & 355222116130601 & 38.0 & 1,664 & 5.59 & 1,083 & 7.83 \\
\hline Willow Spring & Hershey, 1989 & $06 / 26 / 1985$ & - & 10.5 & 718 & - & 253.7 & 7.53 \\
\hline Horse Springs & Drakos and Hodgins, 2013 & $03 / 05 / 2012$ & - & 15.1 & 509 & 6.15 & 290 & 7.66 \\
\hline Horse Springs & Paces and others, 2002 & $06 / 23 / 1993$ & - & - & - & - & - & - \\
\hline Lost Cabin Spring & Hershey, 1989 & $06 / 17 / 1987$ & 360459115391101 & 33.7 & - & - & - & - \\
\hline Lost Cabin Spring & USGS (NWIS) & $07 / 21 / 2009$ & 360459115391101 & 24.7 & 657 & 3.8 & 432 & 7.7 \\
\hline Lost Cabin Spring & USGS (NWIS) & $12 / 28 / 2009$ & 360459115391101 & 14.2 & 510 & 6.3 & 420 & 7.5 \\
\hline Lost Cabin Spring & USGS (NWIS) & $07 / 23 / 2010$ & 360459115391101 & 21.8 & 634 & 5.3 & 436 & 7.4 \\
\hline Peak Spring & Hershey, 1989 & $06 / 23 / 1987$ & 361541115415001 & 6.9 & 386 & - & 249.9 & 7.61 \\
\hline Peak Spring & USGS (NWIS) & $09 / 03 / 2008$ & 361541115415001 & 4.6 & 127 & 8.2 & 119 & 8 \\
\hline Peak Spring & USGS (NWIS) & $07 / 27 / 2009$ & 361541115415001 & 3.8 & 132 & 8.2 & 123 & 8.1 \\
\hline Peak Spring & USGS (NWIS) & $08 / 10 / 2010$ & 361541115415001 & 4.7 & 126 & - & 112 & 7.8 \\
\hline Rainbow Spring & Hershey, 1989 & $09 / 19 / 1982$ & 360310115303201 & 9.8 & 356 & - & 202.2 & 7.45 \\
\hline Rainbow Spring & Paces and others, 2002 & $06 / 23 / 1993$ & 360310115303201 & - & - & - & - & - \\
\hline Borehole Spring & Source Group, Inc., 2011 & $05 / 02 / 2011$ & 10251290 & 44.0 & 4,176 & 1.95 & 2,711 & 8.71 \\
\hline Borehole Spring & Source Group, Inc., 2011 & $09 / 21 / 2011$ & 10251290 & 47.5 & 4,202 & 1.31 & 2,731 & 8.68 \\
\hline
\end{tabular}


Table 9. Water chemistry of selected samples from the Lower Amargosa Valley and extra-basin contributing areas, California and Nevada.-Continued

[All significant figures reflective of what was reported by sources. Data from the U.S. Geological Survey (USGS) from the USGS National Water Information System (NWIS) database. All analyses are assumed to be reported filtered values. Abbreviations: BLS, below land surface; CA, California; E, estimated value; $\mathrm{HCO}_{3}$, bicarbonate; IC, inductively coupled; ICP, inductively coupled plasma;

ICP-MS, inductively coupled plasma-mass spectrometry; ID, identification; M, detected but not quantified; mg/L, milligram per liter; mm/dd/yyyy, month/day/year; NAD83, North American Datum of 1983; $\mathrm{NA}$, not applicable; ND, not detected; pMC, percent modern carbon; R, radiochemical non-detect; TU, tritium unit; UTM, Universal Transverse Mercator; $\mu \mathrm{g} / \mathrm{L}$, microgram per liter; $\mu \mathrm{S} / \mathrm{cm}$, microsiemens per centimeter; ${ }^{\circ} \mathrm{C}$, degrees Celsius; \%o, per mil; $\delta$, delta; $<$, less than; - , no data available]

\begin{tabular}{|c|c|c|c|c|c|c|c|c|c|}
\hline Site name & $\begin{array}{l}\text { Source } \\
\text { of data }\end{array}$ & $\begin{array}{c}\text { Sample } \\
\text { collection date } \\
\text { (mm/dd/yyyy) }\end{array}$ & \multicolumn{2}{|c|}{$\begin{array}{l}\text { USGS site ID } \\
\text { (if applicable) }\end{array}$} & $\begin{array}{l}\text { Water } \\
\text { emperature } \\
\left({ }^{\circ} \mathrm{C}\right)\end{array}$ & $\begin{array}{c}\text { Specific } \\
\text { conductance } \\
\text { ( } \mu \mathrm{S} / \mathrm{cm} \text { at } \\
\left.25^{\circ} \mathrm{C}\right)\end{array}$ & $\begin{array}{l}\text { Dissolved } \\
\text { oxygen } \\
\text { (mg/L) }\end{array}$ & $\begin{array}{c}\text { Total } \\
\text { dissolved } \\
\text { solids } \\
\text { (mg/L) }\end{array}$ & $\mathrm{pH}$ \\
\hline Tecopa Hot Springs & Hershey and others, 2009 & $05 / 04 / 1992$ & \multicolumn{2}{|c|}{355219116135901} & 42 & 3,700 & - & - & 8.2 \\
\hline Tecopa Hot Springs & Larsen and others, 2001 & $01 / 06 / 1997$ & \multicolumn{2}{|c|}{355219116135901} & 39.0 & 3,550 & - & - & 8.2 \\
\hline Tecopa Hot Springs & Source Group, Inc., 2011 & $04 / 27 / 2011$ & \multicolumn{2}{|c|}{355219116135901} & 40.8 & - & - & 2,300 & 8.61 \\
\hline Tecopa Hot Springs & Source Group, Inc., 2011 & $09 / 21 / 2011$ & \multicolumn{2}{|c|}{355219116135901} & 38.9 & 6,400 & 2.74 & 4,100 & 9.18 \\
\hline Tecopa Hot Springs & Steinkampf and Werrell, 2001 & $06 / 30 / 1985$ & \multicolumn{2}{|c|}{355219116135901} & 42.0 & 1,650 & - & - & 8.2 \\
\hline Site name & $\begin{array}{l}\text { Source } \\
\text { of data }\end{array}$ & $\begin{array}{c}\text { Sample } \\
\text { collection date } \\
\text { (mm/dd/yyyy) }\end{array}$ & $\begin{array}{c}\text { Bicarbonate } \\
\text { (mg/L) }\end{array}$ & $\begin{array}{c}\text { Alkalinity } \\
\text { (mg/L as } \\
\left.\mathrm{HCO}_{3}\right)\end{array}$ & $\begin{array}{cc}\text { Calcium } \\
\text { (mg/L) }\end{array}$ & $\begin{array}{c}\text { Magnesium } \\
(\mathrm{mg} / \mathrm{L})\end{array}$ & $\begin{array}{c}\text { Sodium } \\
\text { (mg/L) }\end{array}$ & $\begin{array}{l}\text { Potassium } \\
\text { (mg/L) }\end{array}$ & $\begin{array}{c}\text { Chloride } \\
\text { (mg/L) }\end{array}$ \\
\hline Amargosa Canyon Spring 1 & Source Group, Inc., 2011 & $04 / 25 / 2011$ & - & 290 & 41 & 30 & 140 & 25 & 53 \\
\hline Amargosa Canyon Spring 1 & Source Group, Inc., 2011 & $12 / 22 / 2011$ & - & - & - & - & - & - & - \\
\hline Amargosa Canyon Spring 4 & Source Group, Inc., 2011 & $04 / 25 / 2011$ & - & 380 & 39 & 31 & 200 & 25 & 52 \\
\hline Amargosa Canyon Spring 4 & Source Group, Inc., 2011 & $12 / 22 / 2011$ & - & - & - & - & - & - & - \\
\hline Willow Spring & Larsen and others, 2001 & $01 / 04 / 1999$ & - & 289 & 62 & 47 & 132 & 18 & 47 \\
\hline Willow Spring & Paces and others, 2002 & 03/11/1993 & - & - & - & - & - & - & - \\
\hline Willow Spring & Source Group, Inc., 2011 & $04 / 26 / 2011$ & - & - & 64 & 43 & 110 & 22 & 53 \\
\hline Willow Spring & Source Group, Inc., 2011 & $09 / 23 / 2011$ & - & - & - & - & - & - & - \\
\hline Amargosa River (AR3314; Seepage Run) & USGS (NWIS) & $03 / 27 / 2014$ & - & 1,620 & 15.7 & 31.2 & 3,140 & 187 & 1,790 \\
\hline Amargosa River 2 & Source Group, Inc., 2011 & $11 / 17 / 2010$ & - & - & - & - & - & - & - \\
\hline Amargosa River 2 & Source Group, Inc., 2011 & $05 / 02 / 2011$ & - & 720 & 58 & 61 & 830 & 64 & 380 \\
\hline Amargosa River at Tecopa, CA & USGS (NWIS) & $03 / 15 / 2005$ & 681 & - & 26.6 & 27 & 1,550 & 63.1 & 845 \\
\hline Amargosa River at Tecopa, CA & USGS (NWIS) & $03 / 27 / 2014$ & - & 1,560 & 11.8 & 7.84 & 2,080 & 46.1 & 1,130 \\
\hline Amargosa River in Upper Canyon near Tecopa, CA & USGS (NWIS) & $03 / 15 / 2005$ & 610 & 580 & 46.5 & 41.9 & 660 & 40.7 & 295 \\
\hline Crystal Pool & Dudley and Larsen, 1976 & $11 / 1966$ & - & - & - & - & - & - & - \\
\hline Crystal Pool & Gomez and others, 2013 & - & 301.13 & - & 45.48 & 20.41 & 73.29 & 9.08 & 22.57 \\
\hline Crystal Pool & Hershey and others, 2010 & $03 / 17 / 1992$ & 305 & - & 46.2 & 21.4 & 76.1 & 9.60 & 23.7 \\
\hline Crystal Pool & USGS (NWIS) & 05/07/1997 & - & 310 & 46.6 & 19.9 & 71.3 & 2.20 & 22.8 \\
\hline
\end{tabular}


[All significant figures reflective of what was reported by sources. Data from the U.S. Geological Survey (USGS) from the USGS National Water Information System (NWIS) database. All analyses are assumed to be reported filtered values. Abbreviations: BLS, below land surface; CA, California; E, estimated value; $\mathrm{HCO}_{3}$, bicarbonate; IC, inductively coupled; ICP, inductively coupled plasma; ICP-MS, inductively coupled plasma-mass spectrometry; ID, identification; M, detected but not quantified; mg/L, milligram per liter; mm/dd/yyyy, month/day/year; NAD83, North American Datum of 1983; NA, not applicable; ND, not detected; pMC, percent modern carbon; R, radiochemical non-detect; TU, tritium unit; UTM, Universal Transverse Mercator; $\mu \mathrm{g} / \mathrm{L}$, microgram per liter; $\mu \mathrm{S} / \mathrm{cm}$, microsiemens per centimeter; ${ }^{\circ} \mathrm{C}$, degrees Celsius; \%o, per mil; $\delta$, delta; <, less than; - , no data available]

\begin{tabular}{|c|c|c|c|c|c|c|c|c|c|}
\hline Site name & $\begin{array}{l}\text { Source } \\
\text { of data }\end{array}$ & $\begin{array}{c}\text { Sample } \\
\text { collection date } \\
\text { (mm/dd/yyyy) }\end{array}$ & $\begin{array}{c}\text { Bicarbonate } \\
\text { (mg/L) }\end{array}$ & $\begin{array}{c}\text { Alkalinity } \\
\text { (mg/L as } \\
\mathrm{HCO}_{3} \text { ) }\end{array}$ & $\begin{array}{l}\text { Calcium } \\
\text { (mg/L) }\end{array}$ & $\begin{array}{l}\text { Magnesium } \\
\text { (mg/L) }\end{array}$ & $\begin{array}{c}\text { Sodium } \\
\text { (mg/L) }\end{array}$ & $\begin{array}{l}\text { Potassium } \\
\text { (mg/L) }\end{array}$ & $\begin{array}{c}\text { Chloride } \\
\text { (mg/L) }\end{array}$ \\
\hline Devils Hole (AM-4) & Thomas and others, 1996 & - & 290 & - & 49 & 21 & 67 & 7.9 & 21 \\
\hline Devils Hole (AM-4) & Gomez and others, 2013 & - & 306.72 & - & 49.74 & 21.42 & 67.75 & 7.86 & 22.43 \\
\hline Devils Hole (AM-4) & Hershey and others, 2009 & 07/09/1992 & 294 & - & 48.6 & 20.4 & 67.7 & 8.8 & 20.7 \\
\hline Devils Hole (AM-4) & USGS (NWIS) & 06/03/1984 & - & - & 48 & 21 & 70 & - & - \\
\hline Devils Hole (AM-4) & USGS (NWIS) & 06/03/1984 & - & - & 48 & 21 & 69 & - & - \\
\hline Devils Hole (AM-4) & USGS (NWIS) & 03/09/1985 & - & - & 46 & 22 & 67 & 7.9 & 22 \\
\hline Devils Hole (AM-4) & USGS (NWIS) & 03/09/1985 & - & - & 53 & 22 & 67 & 8 & 21 \\
\hline Devils Hole (AM-4) & USGS (NWIS) & 03/10/1985 & - & - & 52 & 22 & 67 & 7.9 & 21 \\
\hline Devils Hole (AM-4) & USGS (NWIS) & 05/05/1986 & - & - & - & - & - & - & - \\
\hline Devils Hole (AM-4) & USGS (NWIS) & 05/05/1986 & - & - & - & - & - & - & - \\
\hline Devils Hole (AM-4) & USGS (NWIS) & $11 / 16 / 1986$ & - & - & - & - & - & - & - \\
\hline Devils Hole (AM-4) & USGS (NWIS) & $11 / 16 / 1986$ & - & - & - & - & - & - & - \\
\hline Devils Hole (AM-4) & USGS (NWIS) & $06 / 22 / 1987$ & - & - & - & - & - & - & - \\
\hline Devils Hole (AM-4) & USGS (NWIS) & $06 / 22 / 1987$ & - & - & - & - & - & - & - \\
\hline Devils Hole (AM-4) & USGS (NWIS) & 03/16/1988 & - & - & - & - & - & - & - \\
\hline Devils Hole (AM-4) & USGS (NWIS) & 03/16/1988 & - & - & - & - & - & - & - \\
\hline Devils Hole (AM-4) & USGS (NWIS) & $12 / 07 / 1988$ & - & - & - & - & - & - & - \\
\hline Devils Hole (AM-4) & USGS (NWIS) & $12 / 07 / 1988$ & - & - & - & - & - & - & - \\
\hline Devils Hole (AM-4) & USGS (NWIS) & 06/21/1989 & - & - & - & - & - & - & - \\
\hline Devils Hole (AM-4) & USGS (NWIS) & 06/21/1989 & - & - & - & - & - & - & - \\
\hline Devils Hole (AM-4) & USGS (NWIS) & $06 / 25 / 1990$ & - & - & - & - & - & - & - \\
\hline Devils Hole (AM-4) & USGS (NWIS) & 06/25/1990 & - & - & - & - & - & - & - \\
\hline Devils Hole (AM-4) & USGS (NWIS) & 08/22/1990 & - & - & 50 & 20 & 68 & 7.8 & 24 \\
\hline Devils Hole (AM-4) & USGS (NWIS) & 08/15/1991 & - & - & - & - & - & - & - \\
\hline Devils Hole (AM-4) & USGS (NWIS) & 08/27/1991 & - & - & 49 & 21 & 69 & 7.9 & 24 \\
\hline Devils Hole (AM-4) & USGS (NWIS) & 08/19/1992 & - & - & 51 & 21 & 69 & 7.4 & 25 \\
\hline Devils Hole (AM-4) & USGS (NWIS) & 08/18/1999 & - & - & 45.2 & 19.4 & 64 & 7.8 & 20.3 \\
\hline Devils Hole (AM-4) & USGS (NWIS) & 08/18/1999 & - & - & - & - & - & - & - \\
\hline
\end{tabular}


Table 9. Water chemistry of selected samples from the Lower Amargosa Valley and extra-basin contributing areas, California and Nevada.-Continued

[All significant figures reflective of what was reported by sources. Data from the U.S. Geological Survey (USGS) from the USGS National Water Information System (NWIS) database. All analyses are assumed to be reported filtered values. Abbreviations: BLS, below land surface; CA, California; E, estimated value; $\mathrm{HCO}_{3}$, bicarbonate; IC, inductively coupled; ICP, inductively coupled plasma;

ICP-MS, inductively coupled plasma-mass spectrometry; ID, identification; M, detected but not quantified; mg/L, milligram per liter; mm/dd/yyyy, month/day/year; NAD83, North American Datum of 1983; $\mathrm{NA}$, not applicable; ND, not detected; pMC, percent modern carbon; R, radiochemical non-detect; TU, tritium unit; UTM, Universal Transverse Mercator; $\mu \mathrm{g} / \mathrm{L}$, microgram per liter; $\mu \mathrm{S} / \mathrm{cm}$, microsiemens per centimeter; ${ }^{\circ} \mathrm{C}$, degrees Celsius; \%o, per mil; $\delta$, delta; $<$, less than; - , no data available]

\begin{tabular}{|c|c|c|c|c|c|c|c|c|c|}
\hline Site name & $\begin{array}{l}\text { Source } \\
\text { of data }\end{array}$ & $\begin{array}{c}\text { Sample } \\
\text { collection date } \\
\text { (mm/dd/yyyy) }\end{array}$ & $\begin{array}{c}\text { Bicarbonate } \\
\text { (mg/L) }\end{array}$ & $\begin{array}{c}\text { Alkalinity } \\
\text { (mg/L as } \\
\mathrm{HCO}_{3} \text { ) }\end{array}$ & $\begin{array}{c}\text { Calcium } \\
\text { (mg/L) }\end{array}$ & $\begin{array}{c}\text { Magnesium } \\
\text { (mg/L) }\end{array}$ & $\begin{array}{l}\text { Sodium } \\
\text { (mg/L) }\end{array}$ & $\begin{array}{l}\text { Potassium } \\
\text { (mg/L) }\end{array}$ & $\begin{array}{c}\text { Chloride } \\
\text { (mg/L) }\end{array}$ \\
\hline Devils Hole (AM-4) & USGS (NWIS) & $08 / 18 / 1999$ & - & - & - & - & - & - & - \\
\hline Devils Hole (AM-4) & USGS (NWIS) & 09/23/1999 & - & - & - & - & - & - & - \\
\hline Devils Hole (AM-4) & USGS (NWIS) & $09 / 10 / 2003$ & - & - & 52.2 & 21.2 & 66.5 & 7.95 & 20.9 \\
\hline Devils Hole (AM-4) & USGS (NWIS) & 09/10/2003 & - & - & - & - & - & - & - \\
\hline Devils Hole (AM-4) & USGS (NWIS) & $09 / 27 / 2005$ & - & 205 & 50.3 & 21.4 & 65.1 & 7.36 & 20.8 \\
\hline Devils Hole (AM-4) & USGS (NWIS) & $09 / 27 / 2005$ & - & - & - & - & - & - & - \\
\hline Fairbanks Spring & Dudley and Larsen, 1976 & $11 / 1966$ & - & - & - & - & - & - & - \\
\hline Fairbanks Spring & Gomez and others, 2013 & - & 302.33 & - & 47.13 & 21.10 & 69.31 & 7.97 & 21.40 \\
\hline Fairbanks Spring & Hershey and others, 2010 & 03/17/1992 & 310 & - & 48.6 & 20.4 & 67.7 & 8.80 & 20.7 \\
\hline Fairbanks Spring & Thomas and others, 1996 & - & 310 & - & 48 & 21 & 69 & 8.0 & 21 \\
\hline Fairbanks Spring & USGS (NWIS) & 05/06/1997 & - & 305 & 48.6 & 20.3 & 71.3 & 7.87 & 20.8 \\
\hline Five Springs well (AM-2) & Gomez and others, 2013 & - & 296.86 & - & 45.71 & 20.0 & 67.71 & 8.09 & 22.29 \\
\hline Five Springs well (AM-2) & Source Group, Inc., 2011 & 05/01/2011 & - & 320 & 50 & 19 & 64 & 9 & 20 \\
\hline Five Springs well (AM-2) & USGS (NWIS) & 08/24/1990 & 301 & - & 45.0 & 19.0 & 66.0 & 8.3 & 21.0 \\
\hline Five Springs well (AM-2) & USGS (NWIS) & 04/28/1992 & 307 & - & 49.0 & 20.0 & 67.0 & 8.0 & 26.0 \\
\hline Five Springs well (AM-2) & USGS (NWIS) & $10 / 18 / 1994$ & 141 & - & 23.0 & 2.6 & 56 & 9 & 10 \\
\hline Five Springs well (AM-2) & USGS (NWIS) & 09/22/1996 & 211 & - & 46.0 & 20.0 & 68.0 & 7.9 & 21.0 \\
\hline Hog Farm well & Zdon and Associates, 2014 & $04 / 25 / 2013$ & 440 & 470 & 1.6 & 1.4 & 300 & 24 & 49 \\
\hline Point of Rocks Spring & Gomez and others, 2013 & - & 303.70 & - & 49.0 & 20.25 & 67.25 & 7.53 & 21.75 \\
\hline Point of Rocks Spring & Hershey and others, 2010 & - & 310 & - & 49 & 21 & 69 & 7.7 & 21 \\
\hline Tule Spring & Hershey, 1989 & 06/30/1985 & - & - & - & - & - & - & - \\
\hline Tule Spring & USGS (NWIS) & $01 / 16 / 2013$ & - & - & 56.2 & 32.4 & 72.8 & 11.1 & 35.4 \\
\hline Resting Spring & Paces and others, 2002 & 03/11/1993 & - & - & - & - & - & - & - \\
\hline Resting Spring & Source Group, Inc., 2011 & $01 / 23 / 2011$ & - & - & - & - & - & - & - \\
\hline Resting Spring & Source Group, Inc., 2011 & $05 / 25 / 2011$ & - & 240 & 24 & 25 & 110 & 21 & 54 \\
\hline Twelvemile Spring & Zdon and Associates, 2014 & $04 / 25 / 2013$ & 980 & 980 & 340 & 33 & 79 & 13 & 46 \\
\hline Twelvemile Spring & Source Group, Inc., 2011 & $11 / 14 / 2010$ & - & - & - & - & - & - & - \\
\hline Twelvemile Spring & USGS (NWIS) & $03 / 21 / 2013$ & - & 177 & 43.4 & 24.2 & 75.5 & 11.3 & 46.1 \\
\hline
\end{tabular}


[All significant figures reflective of what was reported by sources. Data from the U.S. Geological Survey (USGS) from the USGS National Water Information System (NWIS) database. All analyses are assumed to be reported filtered values. Abbreviations: BLS, below land surface; CA, California; E, estimated value; $\mathrm{HCO}_{3}$, bicarbonate; IC, inductively coupled; ICP, inductively coupled plasma; ICP-MS, inductively coupled plasma-mass spectrometry; ID, identification; M, detected but not quantified; mg/L, milligram per liter; mm/dd/yyyy, month/day/year; NAD83, North American Datum of 1983; NA, not applicable; ND, not detected; pMC, percent modern carbon; R, radiochemical non-detect; TU, tritium unit; UTM, Universal Transverse Mercator; $\mu \mathrm{g} / \mathrm{L}$, microgram per liter; $\mu \mathrm{S} / \mathrm{cm}$, microsiemens per centimeter; ${ }^{\circ} \mathrm{C}$, degrees Celsius; \%o, per mil; $\delta$, delta; <, less than; - , no data available]

\begin{tabular}{|c|c|c|c|c|c|c|c|c|c|}
\hline Site name & $\begin{array}{l}\text { Source } \\
\text { of data }\end{array}$ & $\begin{array}{c}\text { Sample } \\
\text { collection date } \\
\text { (mm/dd/yyyy) }\end{array}$ & $\begin{array}{c}\text { Bicarbonate } \\
\text { (mg/L) }\end{array}$ & $\begin{array}{c}\text { Alkalinity } \\
\text { (mg/L as } \\
\mathrm{HCO}_{3} \text { ) }\end{array}$ & $\begin{array}{l}\text { Calcium } \\
\text { (mg/L) }\end{array}$ & $\begin{array}{l}\text { Magnesium } \\
\text { (mg/L) }\end{array}$ & $\begin{array}{l}\text { Sodium } \\
\text { (mg/L) }\end{array}$ & $\begin{array}{l}\text { Potassium } \\
\text { (mg/L) }\end{array}$ & $\begin{array}{c}\text { Chloride } \\
\text { (mg/L) }\end{array}$ \\
\hline Salsberry Spring & Paces and others, 2002 & 06/17/1998 & - & - & - & - & - & - & - \\
\hline Salsberry Spring & USGS (NWIS) & $03 / 11 / 2013$ & - & - & 6.89 & 0.955 & 63.3 & 1.34 & 13.9 \\
\hline Crystal Spring & Drakos and Hodgins, 2013 & $03 / 14 / 2012$ & 237.0 & 194 & 59.9 & 22.6 & 13.9 & 0.3 & 9.66 \\
\hline Crystal Spring & Paces and others, 2002 & 02/05/1990 & - & - & - & - & - & - & - \\
\hline Crystal Spring & Zdon and Associates, 2014 & $04 / 26 / 2011$ & - & - & - & - & - & - & - \\
\hline Crystal Spring & Zdon and Associates, 2014 & $04 / 27 / 2011$ & - & 240 & 42 & 43 & 21 & 3.5 & 13 \\
\hline Crystal Spring & USGS (NWIS) & 08/10/1994 & 122 & - & 8.3 & 0.5 & 48.0 & 5.6 & - \\
\hline Crystal Spring & USGS (NWIS) & 08/10/1994 & 258 & - & 44.0 & 22.0 & 36.0 & 6.0 & 12.0 \\
\hline Crystal Spring & USGS (NWIS) & 09/23/1996 & - & - & - & - & - & - & - \\
\hline Crystal Spring & USGS (NWIS) & 07/27/1998 & - & - & 13.0 & 0.2 & 60.0 & 2.6 & 65.0 \\
\hline Nevada National Security Site well & Gomez and others, 2013 & - & 237.70 & - & 32.80 & 12.02 & 55.25 & 8.89 & 13.25 \\
\hline 162 S20 E 5323 ABAD1 U19 & USGS (NWIS) & $11 / 07 / 2013$ & 234 & 193 & 44.7 & 23.2 & 4.2 & 1.12 & 2.55 \\
\hline Hidden Hills Ranch well & Hershey, 1989 & 07/30/1987 & 232 & - & 55.8 & 26.3 & 13.2 & 1.68 & 3.0 \\
\hline Jeep Trail well & Drakos and Hodgins, 2013 & 03/16/2012 & 146.0 & 119 & 35.6 & 19.8 & 7.8 & 1.1 & 2.4 \\
\hline NC-GWE-PV-04 & USGS (NWIS) & $06 / 27 / 2012$ & - & - & - & - & - & - & - \\
\hline NC-GWE-PV-04 & USGS (NWIS) & $10 / 15 / 2012$ & - & 148 & 22.9 & 35.9 & 10.8 & 1.96 & 2.84 \\
\hline Stump Spring well & Drakos and Hodgins, 2013 & $02 / 28 / 2012$ & 136.0 & 111 & 31 & 18.4 & 10.2 & 1.8 & 1.3 \\
\hline Stump Spring well & USGS (NWIS) & $06 / 22 / 2009$ & - & 110 & 30.4 & 19.4 & 9.96 & 1.86 & 0.98 \\
\hline Stump Spring well & USGS (NWIS) & $05 / 20 / 2010$ & - & 110 & - & - & - & - & - \\
\hline Black Mountain precipitation & USGS (NWIS) & $03 / 11 / 2013$ & - & - & - & - & - & - & - \\
\hline Kingston Range precipitation & USGS (NWIS) & $01 / 16 / 2013$ & - & - & - & - & - & - & - \\
\hline Mt Charleston precipitation & USGS (NWIS) & $05 / 23 / 2013$ & - & - & - & - & - & - & - \\
\hline Nopah Range precipitation & USGS (NWIS) & 03/19/2013 & - & - & - & - & - & - & - \\
\hline Borax Spring & Larsen and others, 2001 & 01/03/1999 & - & 918 & 0.3 & 0.1 & 799 & 5.10 & 87 \\
\hline Borax Spring & Source Group, Inc., 2011 & $04 / 27 / 2011$ & - & 1,100 & ND & ND & 690 & 12 & 98 \\
\hline Borax Spring & Source Group, Inc., 2011 & $09 / 21 / 2011$ & - & - & - & - & - & - & - \\
\hline Chappo Spring & Paces and others, 2002 & 03/12/1993 & - & - & - & - & - & - & - \\
\hline Chappo Spring & Source Group, Inc., 2011 & $05 / 01 / 2011$ & - & 220 & 36 & 23 & 85 & 15 & 46 \\
\hline
\end{tabular}


Table 9. Water chemistry of selected samples from the Lower Amargosa Valley and extra-basin contributing areas, California and Nevada.-Continued

[All significant figures reflective of what was reported by sources. Data from the U.S. Geological Survey (USGS) from the USGS National Water Information System (NWIS) database. All analyses are assumed to be reported filtered values. Abbreviations: BLS, below land surface; CA, California; E, estimated value; $\mathrm{HCO}_{3}$, bicarbonate; IC, inductively coupled; ICP, inductively coupled plasma;

ICP-MS, inductively coupled plasma-mass spectrometry; ID, identification; M, detected but not quantified; mg/L, milligram per liter; mm/dd/yyyy, month/day/year; NAD83, North American Datum of 1983; $\mathrm{NA}$, not applicable; ND, not detected; pMC, percent modern carbon; R, radiochemical non-detect; TU, tritium unit; UTM, Universal Transverse Mercator; $\mu \mathrm{g} / \mathrm{L}$, microgram per liter; $\mu \mathrm{S} / \mathrm{cm}$, microsiemens per centimeter; ${ }^{\circ} \mathrm{C}$, degrees Celsius; \%o, per mil; $\delta$, delta; $<$, less than; - , no data available]

\begin{tabular}{|c|c|c|c|c|c|c|c|c|c|}
\hline Site name & $\begin{array}{l}\text { Source } \\
\text { of data }\end{array}$ & $\begin{array}{c}\text { Sample } \\
\text { collection date } \\
\text { (mm/dd/yyyy) }\end{array}$ & $\begin{array}{c}\text { Bicarbonate } \\
\text { (mg/L) }\end{array}$ & $\begin{array}{c}\text { Alkalinity } \\
\text { (mg/L as } \\
\mathrm{HCO}_{3} \text { ) }\end{array}$ & $\begin{array}{l}\text { Calcium } \\
\text { (mg/L) }\end{array}$ & $\begin{array}{l}\text { Magnesium } \\
\text { (mg/L) }\end{array}$ & $\begin{array}{l}\text { Sodium } \\
\text { (mg/L) }\end{array}$ & $\begin{array}{l}\text { Potassium } \\
\text { (mg/L) }\end{array}$ & $\begin{array}{l}\text { Chloride } \\
\text { (mg/L) }\end{array}$ \\
\hline Chappo Spring & Larsen and others, 2001 & 01/05/1999 & - & 157 & 31 & 25 & 85 & 13 & 35 \\
\hline Cynthia's well & Zdon and Associates, 2014 & $04 / 25 / 2013$ & 300 & 320 & 16 & 19 & - & - & 43 \\
\hline Cynthia's well & Source Group, Inc., 2011 & $05 / 11 / 2011$ & - & 390 & 20 & 21 & 210 & 17 & 46 \\
\hline Cynthia's well & Zdon and Associates, 2014 & $01 / 16 / 2011$ & - & - & - & - & - & - & - \\
\hline Shoshone Spring & Larsen and others, 2001 & $01 / 16 / 1962$ & - & 250 & 46 & 24 & 252 & 22 & 148 \\
\hline Shoshone Spring & Larsen and others, 2001 & $02 / 27 / 1976$ & - & 255 & 35 & 32 & 240 & 21 & 144 \\
\hline Shoshone Spring & Larsen and others, 2001 & 01/06/1997 & - & 251 & 37 & 30 & 248 & 24 & 121 \\
\hline Shoshone Spring & Source Group, Inc., 2011 & $01 / 23 / 2011$ & - & - & - & - & - & - & - \\
\hline Shoshone Spring & Source Group, Inc., 2011 & $04 / 27 / 2011$ & - & 300 & 43 & 24 & 220 & 28 & 140 \\
\hline Shoshone Spring & USGS (NWIS) & 03/10/1998 & - & - & - & - & - & - & - \\
\hline Thom Spring & Source Group, Inc., 2011 & $11 / 11 / 2010$ & - & - & - & - & - & - & - \\
\hline Thom Spring & Source Group, Inc., 2011 & $04 / 27 / 2011$ & - & 390 & 23 & 18 & 290 & 31 & 100 \\
\hline Wild Bath Spring & USGS (NWIS) & 06/10/1998 & - & - & - & - & - & - & - \\
\hline Wild Bath Spring & Source Group, Inc., 2011 & $04 / 27 / 2011$ & - & 380 & 20 & 11 & 300 & 29 & 100 \\
\hline Wild Bath Spring & Source Group, Inc., 2011 & $09 / 21 / 2011$ & - & - & - & - & - & - & - \\
\hline Willow Spring & Hershey, 1989 & $06 / 26 / 1985$ & 259 & - & 72.2 & 14.9 & 2.1 & 0.6 & 1.8 \\
\hline Horse Springs & Drakos and Hodgins, 2013 & 03/05/2012 & 265.0 & 217 & 60.7 & 29.6 & 6 & 0.9 & 5.36 \\
\hline Horse Springs & Paces and others, 2002 & $06 / 23 / 1993$ & - & - & - & - & - & - & - \\
\hline Lost Cabin Spring & Hershey, 1989 & 06/17/1987 & - & - & - & - & - & - & - \\
\hline Lost Cabin Spring & USGS (NWIS) & 07/21/2009 & - & 172 & - & - & - & - & 12.6 \\
\hline Lost Cabin Spring & USGS (NWIS) & $12 / 28 / 2009$ & - & 167 & 64.5 & 32.4 & 18 & 1.5 & 11.8 \\
\hline Lost Cabin Spring & USGS (NWIS) & 07/23/2010 & - & 184 & 71.9 & 35.5 & 20.5 & 1.7 & 13.2 \\
\hline Peak Spring & Hershey, 1989 & $06 / 23 / 1987$ & 325 & - & 66.7 & 8.6 & 1.1 & 0.4 & 0.7 \\
\hline Peak Spring & USGS (NWIS) & 09/03/2008 & - & 92 & 30.2 & 7.22 & 0.74 & 0.3 & 0.43 \\
\hline Peak Spring & USGS (NWIS) & 07/27/2009 & - & 92 & - & - & - & - & 0.45 \\
\hline Peak Spring & USGS (NWIS) & $08 / 10 / 2010$ & - & 84 & 31.2 & 7.15 & 0.79 & 0.25 & 0.45 \\
\hline Rainbow Spring & Hershey, 1989 & 09/19/1982 & 360 & - & 58.3 & 41.0 & 5.8 & 1.36 & 5.3 \\
\hline Rainbow Spring & Paces and others, 2002 & 06/23/1993 & - & - & - & - & - & - & - \\
\hline
\end{tabular}


[All significant figures reflective of what was reported by sources. Data from the U.S. Geological Survey (USGS) from the USGS National Water Information System (NWIS) database. All analyses are assumed to be reported filtered values. Abbreviations: BLS, below land surface; CA, California; E, estimated value; $\mathrm{HCO}_{3}$, bicarbonate; IC, inductively coupled; ICP, inductively coupled plasma; ICP-MS, inductively coupled plasma-mass spectrometry; ID, identification; M, detected but not quantified; mg/L, milligram per liter; mm/dd/yyyy, month/day/year; NAD83, North American Datum of 1983; NA, not applicable; ND, not detected; pMC, percent modern carbon; R, radiochemical non-detect; TU, tritium unit; UTM, Universal Transverse Mercator; $\mu \mathrm{g} / \mathrm{L}$, microgram per liter; $\mu \mathrm{S} / \mathrm{cm}$, microsiemens per centimeter; ${ }^{\circ} \mathrm{C}$, degrees Celsius; $\%$, per mil; $\delta$, delta; $<$, less than; - , no data available]

\begin{tabular}{|c|c|c|c|c|c|c|c|c|c|c|}
\hline Site name & $\begin{array}{l}\text { Source } \\
\text { of data }\end{array}$ & $\begin{array}{c}\text { Sample } \\
\text { collection date } \\
\text { (mm/dd/yyyy) }\end{array}$ & $\begin{array}{c}\text { Bicarbonate } \\
\text { (mg/L) }\end{array}$ & \multicolumn{2}{|c|}{$\begin{array}{c}\text { Alkalinity } \\
\text { (mg/L as } \\
\left.\mathrm{HCO}_{3}\right)\end{array}$} & $\begin{array}{l}\text { Calcium } \mathrm{Ma} \\
\text { (mg/L) }\end{array}$ & $\begin{array}{l}\text { Magnesium } \\
\text { (mg/L) }\end{array}$ & $\begin{array}{c}\text { Sodium } \\
\text { (mg/L) }\end{array}$ & $\begin{array}{l}\text { Potassium } \\
\text { (mg/L) }\end{array}$ & $\begin{array}{c}\text { Chloride } \\
\text { (mg/L) }\end{array}$ \\
\hline Borehole Spring & Source Group, Inc., 2011 & $05 / 02 / 2011$ & - & \multicolumn{2}{|c|}{590} & 3.8 & 0.96 & 760 & 27 & 530 \\
\hline Borehole Spring & Source Group, Inc., 2011 & $09 / 21 / 2011$ & - & \multicolumn{2}{|c|}{ - } & - & - & - & - & - \\
\hline Tecopa Hot Springs & Hershey and others, 2009 & 05/04/1992 & 708 & \multicolumn{2}{|c|}{-} & 4.55 & 1.47 & 783 & 17.6 & 423 \\
\hline Tecopa Hot Springs & Larsen and others, 2001 & 01/06/1997 & - & \multicolumn{2}{|c|}{508} & 3.8 & 0.4 & 830 & 18 & 683 \\
\hline Tecopa Hot Springs & Source Group, Inc., 2011 & $04 / 27 / 2011$ & - & \multicolumn{2}{|c|}{540} & 2.3 & 0.34 & 850 & 29 & 570 \\
\hline Tecopa Hot Springs & Source Group, Inc., 2011 & $09 / 21 / 2011$ & - & \multicolumn{2}{|c|}{ - } & - & - & - & - & - \\
\hline Tecopa Hot Springs & Steinkampf and Werrell, 2001 & 06/30/1985 & 730 & \multicolumn{2}{|c|}{ - } & 4.0 & 1.5 & 850 & 16 & 460 \\
\hline Site name & $\begin{array}{l}\text { Source } \\
\text { of data }\end{array}$ & $\begin{array}{c}\text { Sample } \\
\text { collection date } \\
\text { (mm/dd/yyyy) }\end{array}$ & $\begin{array}{c}\text { Sulfate } \\
\text { (mg/L) }\end{array}$ & $\begin{array}{l}\text { luoride } \\
\text { (mg/L) }\end{array}$ & $\begin{array}{c}\text { Bromide } \\
\text { (mg/L) }\end{array}$ & $\begin{array}{l}\text { Silica } \\
\text { (mg/L) }\end{array}$ & $\begin{array}{c}\text { Aluminum } \\
(\mu \mathrm{g} / \mathrm{L})\end{array}$ & $\begin{array}{c}\text { n Antimony } \\
(\mu \mathrm{g} / \mathrm{L})\end{array}$ & $\begin{array}{c}\text { ny Arsenic } \\
(\mu \mathrm{g} / \mathrm{L})\end{array}$ & $\begin{array}{c}\text { Barium } \\
(\mu \mathrm{g} / \mathrm{L})\end{array}$ \\
\hline Amargosa Canyon Spring 1 & Source Group, Inc., 2011 & $04 / 25 / 2011$ & 170 & 2.5 & - & 48 & - & - & 20 & - \\
\hline Amargosa Canyon Spring 1 & Source Group, Inc., 2011 & $12 / 22 / 2011$ & - & - & - & - & - & - & - & - \\
\hline Amargosa Canyon Spring 4 & Source Group, Inc., 2011 & $04 / 25 / 2011$ & 220 & 3.0 & - & 30 & - & - & - & - \\
\hline Amargosa Canyon Spring 4 & Source Group, Inc., 2011 & $12 / 22 / 2011$ & - & - & - & - & - & - & - & - \\
\hline Willow Spring & Larsen and others, 2001 & 01/04/1999 & 202 & 1.4 & - & 48 & - & - & - & - \\
\hline Willow Spring & Paces and others, 2002 & 03/11/1993 & - & - & - & - & - & - & - & - \\
\hline Willow Spring & Source Group, Inc., 2011 & $04 / 26 / 2011$ & 220 & 2.3 & - & 46 & - & - & - & - \\
\hline Willow Spring & Source Group, Inc., 2011 & $09 / 23 / 2011$ & - & - & - & - & - & - & - & - \\
\hline Amargosa River (AR3314; Seepage Run) & USGS (NWIS) & $03 / 27 / 2014$ & 2,310 & 1.97 & 4.74 & 47.2 & $<22.0$ & 1.27 & 1,040 & 28.1 \\
\hline Amargosa River 2 & Source Group, Inc., 2011 & $11 / 17 / 2010$ & - & - & - & - & - & - & - & - \\
\hline Amargosa River 2 & Source Group, Inc., 2011 & $05 / 02 / 2011$ & 960 & 5.4 & - & 43 & - & - & 150 & - \\
\hline Amargosa River at Tecopa, CA & USGS (NWIS) & $03 / 15 / 2005$ & 1,340 & 4.34 & - & 68.9 & E3.8 & 1.2 & 495 & - \\
\hline Amargosa River at Tecopa, CA & USGS (NWIS) & $03 / 27 / 2014$ & 1,470 & 6.39 & 2.06 & 65.1 & 106 & 0.996 & 747 & 23.4 \\
\hline Amargosa River in Upper Canyon near Tecopa, CA & USGS (NWIS) & $03 / 15 / 2005$ & 680 & 3.73 & - & 58 & E1.8 & 0.55 & 166 & - \\
\hline Crystal Pool & Dudley and Larsen, 1976 & $11 / 1966$ & - & - & - & 25 & - & - & - & - \\
\hline Crystal Pool & Gomez and others, 2013 & - & 84.79 & 1.70 & 0.15 & 26.64 & - & - & - & - \\
\hline Crystal Pool & Hershey and others, 2010 & 03/17/1992 & 84.6 & 1.7 & - & 27.3 & - & - & - & 70 \\
\hline Crystal Pool & USGS (NWIS) & 05/07/1997 & 87.7 & 1.77 & 0.14 & - & 3.3 & $<1.00$ & 15 & 66.7 \\
\hline
\end{tabular}


Table 9. Water chemistry of selected samples from the Lower Amargosa Valley and extra-basin contributing areas, California and Nevada.—Continued

[All significant figures reflective of what was reported by sources. Data from the U.S. Geological Survey (USGS) from the USGS National Water Information System (NWIS) database. All analyses are assumed to be reported filtered values. Abbreviations: BLS, below land surface; CA, California; E, estimated value; $\mathrm{HCO}_{3}$, bicarbonate; IC, inductively coupled; ICP, inductively coupled plasma;

ICP-MS, inductively coupled plasma-mass spectrometry; ID, identification; M, detected but not quantified; mg/L, milligram per liter; mm/dd/yyyy, month/day/year; NAD83, North American Datum of 1983; $\mathrm{NA}$, not applicable; ND, not detected; pMC, percent modern carbon; R, radiochemical non-detect; TU, tritium unit; UTM, Universal Transverse Mercator; $\mu \mathrm{g} / \mathrm{L}$, microgram per liter; $\mu \mathrm{S} / \mathrm{cm}$, microsiemens per centimeter; ${ }^{\circ} \mathrm{C}$, degrees Celsius; \%o, per mil; $\delta$, delta; $<$, less than; - , no data available]

\begin{tabular}{|c|c|c|c|c|c|c|c|c|c|c|}
\hline Site name & $\begin{array}{l}\text { Source } \\
\text { of data }\end{array}$ & $\begin{array}{c}\text { Sample } \\
\text { collection date } \\
\text { (mm/dd/yyyy) }\end{array}$ & $\begin{array}{l}\text { Sulfate } \\
\text { (mg/L) }\end{array}$ & $\begin{array}{l}\text { Fluoride } \\
\text { (mg/L) }\end{array}$ & $\begin{array}{c}\text { Bromide } \\
\text { (mg/L) }\end{array}$ & $\begin{array}{l}\text { Silica } \\
\text { (mg/L) }\end{array}$ & $\begin{array}{l}\text { Aluminum } \\
(\mu \mathrm{g} / \mathrm{L})\end{array}$ & $\begin{array}{c}\text { Antimony } \\
(\mu \mathrm{g} / \mathrm{L})\end{array}$ & $\begin{array}{c}\text { Arsenic } \\
(\mu \mathrm{g} / \mathrm{L})\end{array}$ & $\begin{array}{c}\text { Barium } \\
(\mu \mathrm{g} / \mathrm{L})\end{array}$ \\
\hline Devils Hole (AM-4) & Thomas and others, 1996 & - & 80 & - & - & - & - & - & - & - \\
\hline Devils Hole (AM-4) & Gomez and others, 2013 & - & 80.67 & 1.54 & 0.15 & 22.74 & - & - & - & - \\
\hline Devils Hole (AM-4) & Hershey and others, 2009 & 07/09/1992 & 74.4 & 1.8 & - & 22.9 & - & - & - & 80 \\
\hline Devils Hole (AM-4) & USGS (NWIS) & 06/03/1984 & - & - & - & 23 & - & - & - & 85 \\
\hline Devils Hole (AM-4) & USGS (NWIS) & 06/03/1984 & - & - & - & 23 & - & - & - & 86 \\
\hline Devils Hole (AM-4) & USGS (NWIS) & 03/09/1985 & 83 & 1.5 & 0.1 & 23 & - & - & - & 88 \\
\hline Devils Hole (AM-4) & USGS (NWIS) & 03/09/1985 & 83 & 1.5 & 0.1 & 23 & - & - & - & 88 \\
\hline Devils Hole (AM-4) & USGS (NWIS) & 03/10/1985 & 82 & 1.4 & 0.1 & 23 & - & - & - & 87 \\
\hline Devils Hole (AM-4) & USGS (NWIS) & 05/05/1986 & - & - & - & - & - & - & - & - \\
\hline Devils Hole (AM-4) & USGS (NWIS) & 05/05/1986 & - & - & - & - & - & - & - & - \\
\hline Devils Hole (AM-4) & USGS (NWIS) & $11 / 16 / 1986$ & - & - & - & - & - & - & - & - \\
\hline Devils Hole (AM-4) & USGS (NWIS) & $11 / 16 / 1986$ & - & - & - & - & - & - & - & - \\
\hline Devils Hole (AM-4) & USGS (NWIS) & $06 / 22 / 1987$ & - & - & - & - & - & - & - & - \\
\hline Devils Hole (AM-4) & USGS (NWIS) & $06 / 22 / 1987$ & - & - & - & - & - & - & - & - \\
\hline Devils Hole (AM-4) & USGS (NWIS) & 03/16/1988 & - & - & - & - & - & - & - & - \\
\hline Devils Hole (AM-4) & USGS (NWIS) & 03/16/1988 & - & - & - & - & - & - & - & - \\
\hline Devils Hole (AM-4) & USGS (NWIS) & $12 / 07 / 1988$ & - & - & - & - & - & - & - & - \\
\hline Devils Hole (AM-4) & USGS (NWIS) & $12 / 07 / 1988$ & - & - & - & - & - & - & - & - \\
\hline Devils Hole (AM-4) & USGS (NWIS) & $06 / 21 / 1989$ & - & - & - & - & - & - & - & - \\
\hline Devils Hole (AM-4) & USGS (NWIS) & $06 / 21 / 1989$ & - & - & - & - & - & - & - & - \\
\hline Devils Hole (AM-4) & USGS (NWIS) & $06 / 25 / 1990$ & - & - & - & - & - & - & - & - \\
\hline Devils Hole (AM-4) & USGS (NWIS) & $06 / 25 / 1990$ & - & - & - & - & - & - & - & - \\
\hline Devils Hole (AM-4) & USGS (NWIS) & $08 / 22 / 1990$ & 87 & 1.6 & - & 23 & - & - & 14 & 83 \\
\hline Devils Hole (AM-4) & USGS (NWIS) & 08/15/1991 & - & - & - & - & - & - & - & - \\
\hline Devils Hole (AM-4) & USGS (NWIS) & 08/27/1991 & 83 & 1.6 & - & 23 & - & - & 12 & 81 \\
\hline Devils Hole (AM-4) & USGS (NWIS) & 08/19/1992 & 82 & 1.5 & - & 23 & - & - & 14 & 78 \\
\hline Devils Hole (AM-4) & USGS (NWIS) & 08/18/1999 & 73.8 & 1.49 & 0.13 & 21.5 & 7.1 & $<1.00$ & 13 & 80.9 \\
\hline Devils Hole (AM-4) & USGS (NWIS) & 08/18/1999 & - & - & - & - & 8.2 & $<1.00$ & 14 & 82 \\
\hline
\end{tabular}


[All significant figures reflective of what was reported by sources. Data from the U.S. Geological Survey (USGS) from the USGS National Water Information System (NWIS) database. All analyses are assumed to be reported filtered values. Abbreviations: BLS, below land surface; CA, California; E, estimated value; $\mathrm{HCO}_{3}$, bicarbonate; IC, inductively coupled; ICP, inductively coupled plasma; ICP-MS, inductively coupled plasma-mass spectrometry; ID, identification; M, detected but not quantified; mg/L, milligram per liter; mm/dd/yyyy, month/day/year; NAD83, North American Datum of 1983; NA, not applicable; ND, not detected; pMC, percent modern carbon; R, radiochemical non-detect; TU, tritium unit; UTM, Universal Transverse Mercator; $\mu \mathrm{g} / \mathrm{L}$, microgram per liter; $\mu \mathrm{S} / \mathrm{cm}$, microsiemens per centimeter; ${ }^{\circ} \mathrm{C}$, degrees Celsius; $\%$, per mil; $\delta$, delta; $<$, less than; - , no data available]

\begin{tabular}{|c|c|c|c|c|c|c|c|c|c|c|}
\hline Site name & $\begin{array}{l}\text { Source } \\
\text { of data }\end{array}$ & $\begin{array}{c}\text { Sample } \\
\text { collection date } \\
\text { (mm/dd/yyyy) }\end{array}$ & $\begin{array}{c}\text { Sulfate } \\
\text { (mg/L) }\end{array}$ & $\begin{array}{c}\text { Fluoride } \\
\text { (mg/L) }\end{array}$ & $\begin{array}{c}\text { Bromide } \\
\text { (mg/L) }\end{array}$ & $\begin{array}{l}\text { Silica } \\
\text { (mg/L) }\end{array}$ & $\begin{array}{c}\text { Aluminum } \\
(\mu \mathrm{g} / \mathrm{L})\end{array}$ & $\begin{array}{c}\text { Antimony } \\
(\mu \mathrm{g} / \mathrm{L})\end{array}$ & $\begin{array}{c}\text { Arsenic } \\
\text { ( } \mu \mathrm{g} / \mathrm{L})\end{array}$ & $\begin{array}{c}\text { Barium } \\
\text { ( } \mu \mathrm{g} / \mathrm{L})\end{array}$ \\
\hline Devils Hole (AM-4) & USGS (NWIS) & $08 / 18 / 1999$ & - & - & - & - & - & - & - & - \\
\hline Devils Hole (AM-4) & USGS (NWIS) & 09/23/1999 & - & - & - & - & - & - & - & - \\
\hline Devils Hole (AM-4) & USGS (NWIS) & $09 / 10 / 2003$ & 77.4 & 1.53 & 0.15 & - & E1.0 & E0.168 & 17 & 72.5 \\
\hline Devils Hole (AM-4) & USGS (NWIS) & $09 / 10 / 2003$ & - & - & - & - & - & - & - & - \\
\hline Devils Hole (AM-4) & USGS (NWIS) & $09 / 27 / 2005$ & 78.1 & 1.55 & 0.137 & - & 1.7 & E0.170 & 12 & 75.6 \\
\hline Devils Hole (AM-4) & USGS (NWIS) & $09 / 27 / 2005$ & - & - & - & - & - & - & - & - \\
\hline Fairbanks Spring & Dudley and Larsen, 1976 & $11 / 1966$ & - & - & - & 22 & - & - & - & - \\
\hline Fairbanks Spring & Gomez and others, 2013 & - & 81.45 & 1.79 & - & 22.04 & - & - & - & - \\
\hline Fairbanks Spring & Hershey and others, 2010 & 03/17/1992 & 74.4 & 1.8 & - & 22.9 & - & - & - & 80 \\
\hline Fairbanks Spring & Thomas and others, 1996 & - & 82 & - & - & - & - & - & - & - \\
\hline Fairbanks Spring & USGS (NWIS) & 05/06/1997 & 80.1 & 1.76 & 0.13 & 22.8 & 3.9 & - & 10 & 59.8 \\
\hline Five Springs well (AM-2) & Gomez and others, 2013 & - & 81.86 & 1.66 & 0.15 & 21.86 & - & - & - & - \\
\hline Five Springs well (AM-2) & Source Group, Inc., 2011 & 05/01/2011 & 79 & 1.6 & - & 23 & - & - & 16 & - \\
\hline Five Springs well (AM-2) & USGS (NWIS) & 08/24/1990 & 77 & 1.5 & - & 23 & - & - & - & 63 \\
\hline Five Springs well (AM-2) & USGS (NWIS) & 04/28/1992 & 85 & 1.7 & 0.05 & 21 & 22.0 & - & 14 & 64 \\
\hline Five Springs well (AM-2) & USGS (NWIS) & 10/18/1994 & 31 & 1.7 & - & 21 & 100.0 & - & - & - \\
\hline Five Springs well (AM-2) & USGS (NWIS) & 09/22/1996 & 81 & 1.7 & - & 22 & - & - & - & - \\
\hline Hog Farm well & Zdon and Associates, 2014 & $04 / 25 / 2013$ & 140 & 6.2 & - & 33 & $<500$ & $<10$ & 120 & $<3.0$ \\
\hline Point of Rocks Spring & Gomez and others, 2013 & - & 78.25 & - & - & 21.75 & - & - & - & - \\
\hline Point of Rocks Spring & Hershey and others, 2010 & - & 80 & 1.4 & - & 23 & - & - & - & - \\
\hline Tule Spring & Hershey, 1989 & $06 / 30 / 1985$ & - & - & - & - & - & - & - & - \\
\hline Tule Spring & USGS (NWIS) & $01 / 16 / 2013$ & 130 & 1.7 & $<0.010$ & 39.7 & 3.8 & 0.266 & 21.1 & 49 \\
\hline Resting Spring & Paces and others, 2002 & 03/11/1993 & - & - & - & - & - & - & - & - \\
\hline Resting Spring & Source Group, Inc., 2011 & $01 / 23 / 2011$ & - & - & - & - & - & - & - & - \\
\hline Resting Spring & Source Group, Inc., 2011 & $05 / 25 / 2011$ & 120 & 2.1 & - & 65 & - & - & 59 & - \\
\hline Twelvemile Spring & Zdon and Associates, 2014 & $04 / 25 / 2013$ & 100 & 1.6 & - & 110 & - & $<10$ & 41 & 380 \\
\hline Twelvemile Spring & Source Group, Inc., 2011 & $11 / 14 / 2010$ & - & - & - & - & - & - & - & - \\
\hline Twelvemile Spring & USGS (NWIS) & $03 / 21 / 2013$ & 103 & 1.7 & 0.086 & 23.9 & 3.6 & 0.175 & 31.7 & 41.3 \\
\hline
\end{tabular}


Table 9. Water chemistry of selected samples from the Lower Amargosa Valley and extra-basin contributing areas, California and Nevada.—Continued

[All significant figures reflective of what was reported by sources. Data from the U.S. Geological Survey (USGS) from the USGS National Water Information System (NWIS) database. All analyses are assumed to be reported filtered values. Abbreviations: BLS, below land surface; CA, California; E, estimated value; $\mathrm{HCO}_{3}$, bicarbonate; IC, inductively coupled; ICP, inductively coupled plasma;

ICP-MS, inductively coupled plasma-mass spectrometry; ID, identification; M, detected but not quantified; mg/L, milligram per liter; mm/dd/yyyy, month/day/year; NAD83, North American Datum of 1983; $\mathrm{NA}$, not applicable; ND, not detected; pMC, percent modern carbon; R, radiochemical non-detect; TU, tritium unit; UTM, Universal Transverse Mercator; $\mu \mathrm{g} / \mathrm{L}$, microgram per liter; $\mu \mathrm{S} / \mathrm{cm}$, microsiemens per centimeter; ${ }^{\circ} \mathrm{C}$, degrees Celsius; \%o, per mil; $\delta$, delta; $<$, less than; - , no data available]

\begin{tabular}{|c|c|c|c|c|c|c|c|c|c|c|}
\hline Site name & $\begin{array}{l}\text { Source } \\
\text { of data }\end{array}$ & $\begin{array}{c}\text { Sample } \\
\text { collection date } \\
\text { (mm/dd/yyyy) }\end{array}$ & $\begin{array}{c}\text { Sulfate } \\
\text { (mg/L) }\end{array}$ & $\begin{array}{c}\text { Fluoride } \\
\text { (mg/L) }\end{array}$ & $\begin{array}{c}\text { Bromide } \\
\text { (mg/L) }\end{array}$ & $\begin{array}{l}\text { Silica } \\
\text { (mg/L) }\end{array}$ & $\begin{array}{c}\text { Aluminum } \\
(\mu \mathrm{g} / \mathrm{L})\end{array}$ & $\begin{array}{c}\text { Antimony } \\
(\mu \mathrm{g} / \mathrm{L})\end{array}$ & $\begin{array}{c}\text { Arsenic } \\
\text { ( } \mu \mathrm{g} / \mathrm{L})\end{array}$ & $\begin{array}{c}\text { Barium } \\
(\mu \mathrm{g} / \mathrm{L})\end{array}$ \\
\hline Salsberry Spring & Paces and others, 2002 & $06 / 17 / 1998$ & - & - & - & - & - & - & - & - \\
\hline Salsberry Spring & USGS (NWIS) & $03 / 11 / 2013$ & 16.0 & 0.472 & 0.0159 & 35.6 & 903 & 0.485 & 4.46 & 3.01 \\
\hline Crystal Spring & Drakos and Hodgins, 2013 & $03 / 14 / 2012$ & 17.45 & 0.1 & 0.076 & 22.3 & - & - & ND & - \\
\hline Crystal Spring & Paces and others, 2002 & 02/05/1990 & - & - & - & - & - & - & - & - \\
\hline Crystal Spring & Zdon and Associates, 2014 & $04 / 26 / 2011$ & - & - & - & - & - & - & - & - \\
\hline Crystal Spring & Zdon and Associates, 2014 & $04 / 27 / 2011$ & 60 & 0.66 & - & 26 & - & - & - & - \\
\hline Crystal Spring & USGS (NWIS) & 08/10/1994 & - & - & - & - & - & - & - & - \\
\hline Crystal Spring & USGS (NWIS) & 08/10/1994 & 52.0 & 4.50 & - & 62.0 & 100.0 & - & - & - \\
\hline Crystal Spring & USGS (NWIS) & 09/23/1996 & - & - & - & - & - & - & - & - \\
\hline Crystal Spring & USGS (NWIS) & 07/27/1998 & 230.0 & 2.50 & 0.24 & 68.0 & 10.0 & - & 7.0 & 79.0 \\
\hline Nevada National Security Site well & Gomez and others, 2013 & - & 33.44 & 0.75 & 0.68 & 28.73 & - & - & - & - \\
\hline 162 S20 E 5323 ABAD1 U19 & USGS (NWIS) & $11 / 07 / 2013$ & 24.2 & 0.16 & - & 11.1 & $<2.2$ & $<0.027$ & 0.5 & 51.5 \\
\hline Hidden Hills Ranch well & Hershey, 1989 & 07/30/1987 & 56 & 0.40 & - & 24.0 & - & - & - & - \\
\hline Jeep Trail well & Drakos and Hodgins, 2013 & $03 / 16 / 2012$ & 43.68 & 0.14 & ND & 19.9 & - & - & 8.00 & - \\
\hline NC-GWE-PV-04 & USGS (NWIS) & $06 / 27 / 2012$ & - & - & - & - & - & - & - & - \\
\hline NC-GWE-PV-04 & USGS (NWIS) & $10 / 15 / 2012$ & 25.8 & 0.62 & 0.037 & 35.1 & $<2.2$ & 0.092 & 2.6 & 82.8 \\
\hline Stump Spring well & Drakos and Hodgins, 2013 & $02 / 28 / 2012$ & 37.58 & 0.2 & ND & - & - & - & 1.8 & - \\
\hline Stump Spring well & USGS (NWIS) & $06 / 22 / 2009$ & 35.4 & 0.27 & E0.011 & 23.6 & E3.9 & 0.067 & 1.7 & 68.4 \\
\hline Stump Spring well & USGS (NWIS) & $05 / 20 / 2010$ & - & - & - & - & - & - & - & - \\
\hline Black Mountain precipitation & USGS (NWIS) & $03 / 11 / 2013$ & - & - & - & - & - & - & - & - \\
\hline Kingston Range precipitation & USGS (NWIS) & $01 / 16 / 2013$ & - & - & - & - & - & - & - & - \\
\hline Mt Charleston precipitation & USGS (NWIS) & $05 / 23 / 2013$ & - & - & - & - & - & - & - & - \\
\hline Nopah Range precipitation & USGS (NWIS) & 03/19/2013 & - & - & - & - & - & - & - & - \\
\hline Borax Spring & Larsen and others, 2001 & 01/03/1999 & 179 & 9.6 & - & 97 & - & - & - & - \\
\hline Borax Spring & Source Group, Inc., 2011 & $04 / 27 / 2011$ & 200 & 9.4 & - & 95 & - & - & 1,600 & - \\
\hline Borax Spring & Source Group, Inc., 2011 & 09/21/2011 & - & - & - & - & - & - & - & - \\
\hline Chappo Spring & Paces and others, 2002 & 03/12/1993 & - & - & - & - & - & - & - & - \\
\hline Chappo Spring & Source Group, Inc., 2011 & 05/01/2011 & 100 & 1.9 & - & 34 & - & - & 79 & - \\
\hline
\end{tabular}


[All significant figures reflective of what was reported by sources. Data from the U.S. Geological Survey (USGS) from the USGS National Water Information System (NWIS) database. All analyses are assumed to be reported filtered values. Abbreviations: BLS, below land surface; CA, California; E, estimated value; $\mathrm{HCO}_{3}$, bicarbonate; IC, inductively coupled; ICP, inductively coupled plasma; ICP-MS, inductively coupled plasma-mass spectrometry; ID, identification; M, detected but not quantified; mg/L, milligram per liter; mm/dd/yyyy, month/day/year; NAD83, North American Datum of 1983; NA, not applicable; ND, not detected; pMC, percent modern carbon; R, radiochemical non-detect; TU, tritium unit; UTM, Universal Transverse Mercator; $\mu \mathrm{g} / \mathrm{L}$, microgram per liter; $\mu \mathrm{S} / \mathrm{cm}$, microsiemens per centimeter; ${ }^{\circ} \mathrm{C}$, degrees Celsius; \%o, per mil; $\delta$, delta; $<$, less than; - , no data available]

\begin{tabular}{|c|c|c|c|c|c|c|c|c|c|c|}
\hline Site name & $\begin{array}{l}\text { Source } \\
\text { of data }\end{array}$ & $\begin{array}{c}\text { Sample } \\
\text { collection date } \\
\text { (mm/dd/yyyy) }\end{array}$ & $\begin{array}{c}\text { Sulfate } \\
\text { (mg/L) }\end{array}$ & $\begin{array}{c}\text { Fluoride } \\
\text { (mg/L) }\end{array}$ & $\begin{array}{c}\text { Bromide } \\
\text { (mg/L) }\end{array}$ & $\begin{array}{l}\text { Silica } \\
\text { (mg/L) }\end{array}$ & $\begin{array}{c}\text { Aluminum } \\
(\mu \mathrm{g} / \mathrm{L})\end{array}$ & $\begin{array}{c}\text { Antimony } \\
(\mu \mathrm{g} / \mathrm{L})\end{array}$ & $\begin{array}{c}\text { Arsenic } \\
\text { ( } \mu \mathrm{g} / \mathrm{L})\end{array}$ & $\begin{array}{c}\text { Barium } \\
\text { ( } \mu \mathrm{g} / \mathrm{L})\end{array}$ \\
\hline Chappo Spring & Larsen and others, 2001 & $01 / 05 / 1999$ & 88 & 0.80 & - & 32 & - & - & - & - \\
\hline Cynthia's well & Zdon and Associates, 2014 & $04 / 25 / 2013$ & 210 & 2.8 & - & 52 & $<500$ & $<10$ & 11 & 20 \\
\hline Cynthia's well & Source Group, Inc., 2011 & 05/11/2011 & 220 & 2.7 & - & 67.0 & - & - & 13 & - \\
\hline Cynthia's well & Zdon and Associates, 2014 & $01 / 16 / 2011$ & - & - & - & - & - & - & - & - \\
\hline Shoshone Spring & Larsen and others, 2001 & $01 / 16 / 1962$ & 252 & 2 & - & - & - & - & - & - \\
\hline Shoshone Spring & Larsen and others, 2001 & $02 / 27 / 1976$ & 245 & 2 & - & - & - & - & - & - \\
\hline Shoshone Spring & Larsen and others, 2001 & 01/06/1997 & 229 & 0.8 & - & 41 & - & - & - & - \\
\hline Shoshone Spring & Source Group, Inc., 2011 & $01 / 23 / 2011$ & - & - & - & - & - & - & - & - \\
\hline Shoshone Spring & Source Group, Inc., 2011 & $04 / 27 / 2011$ & 230 & 2.2 & - & 40 & - & - & 71 & - \\
\hline Shoshone Spring & USGS (NWIS) & 03/10/1998 & - & - & - & - & - & - & - & - \\
\hline Thom Spring & Source Group, Inc., 2011 & $11 / 11 / 2010$ & - & - & - & - & - & - & - & - \\
\hline Thom Spring & Source Group, Inc., 2011 & $04 / 27 / 2011$ & 240 & 2.4 & - & 81 & - & - & 88 & - \\
\hline Wild Bath Spring & USGS (NWIS) & 06/10/1998 & - & - & - & - & - & - & - & - \\
\hline Wild Bath Spring & Source Group, Inc., 2011 & $04 / 27 / 2011$ & 240 & 2.2 & - & 96 & - & - & 110 & - \\
\hline Wild Bath Spring & Source Group, Inc., 2011 & $09 / 21 / 2011$ & - & - & - & - & - & - & - & - \\
\hline Willow Spring & Hershey, 1989 & $06 / 26 / 1985$ & 9.9 & 0.15 & - & 7.6 & - & - & - & - \\
\hline Horse Springs & Drakos and Hodgins, 2013 & 03/05/2012 & 9.58 & ND & 0.114 & 11.7 & - & - & ND & - \\
\hline Horse Springs & Paces and others, 2002 & $06 / 23 / 1993$ & - & - & - & - & - & - & - & - \\
\hline Lost Cabin Spring & Hershey, 1989 & 06/17/1987 & - & - & - & - & - & - & - & - \\
\hline Lost Cabin Spring & USGS (NWIS) & $07 / 21 / 2009$ & 122 & 0.27 & 0.152 & - & - & - & - & - \\
\hline Lost Cabin Spring & USGS (NWIS) & $12 / 28 / 2009$ & 115 & 0.28 & 0.138 & 20.2 & E3.0 & E0.049 & 0.85 & 28.8 \\
\hline Lost Cabin Spring & USGS (NWIS) & $07 / 23 / 2010$ & 121 & 0.31 & 0.148 & 19.8 & - & - & - & - \\
\hline Peak Spring & Hershey, 1989 & 06/23/1987 & 4.7 & 0.12 & - & 5.0 & - & - & - & - \\
\hline Peak Spring & USGS (NWIS) & 09/03/2008 & 2.47 & E0.08 & $<0.020$ & 3.81 & 2.4 & $<0.140$ & 0.24 & 10.5 \\
\hline Peak Spring & USGS (NWIS) & $07 / 27 / 2009$ & 4.68 & E0.09 & $<0.020$ & - & - & - & - & - \\
\hline Peak Spring & USGS (NWIS) & $08 / 10 / 2010$ & 2.07 & E0.05 & 0.02 & 4.09 & - & - & - & - \\
\hline Rainbow Spring & Hershey, 1989 & 09/19/1982 & 11.8 & 0.13 & - & 12.0 & - & - & - & - \\
\hline Rainbow Spring & Paces and others, 2002 & 06/23/1993 & - & - & - & - & - & - & - & - \\
\hline
\end{tabular}


Table 9. Water chemistry of selected samples from the Lower Amargosa Valley and extra-basin contributing areas, California and Nevada.-Continued

[All significant figures reflective of what was reported by sources. Data from the U.S. Geological Survey (USGS) from the USGS National Water Information System (NWIS) database. All analyses are assumed to be reported filtered values. Abbreviations: BLS, below land surface; CA, California; E, estimated value; $\mathrm{HCO}_{3}$, bicarbonate; IC, inductively coupled; ICP, inductively coupled plasma;

ICP-MS, inductively coupled plasma-mass spectrometry; ID, identification; M, detected but not quantified; mg/L, milligram per liter; mm/dd/yyyy, month/day/year; NAD83, North American Datum of 1983; $\mathrm{NA}$, not applicable; ND, not detected; pMC, percent modern carbon; R, radiochemical non-detect; TU, tritium unit; UTM, Universal Transverse Mercator; $\mu \mathrm{g} / \mathrm{L}$, microgram per liter; $\mu \mathrm{S} / \mathrm{cm}$, microsiemens per centimeter; ${ }^{\circ} \mathrm{C}$, degrees Celsius; \%o, per mil; $\delta$, delta; $<$, less than; - , no data available]

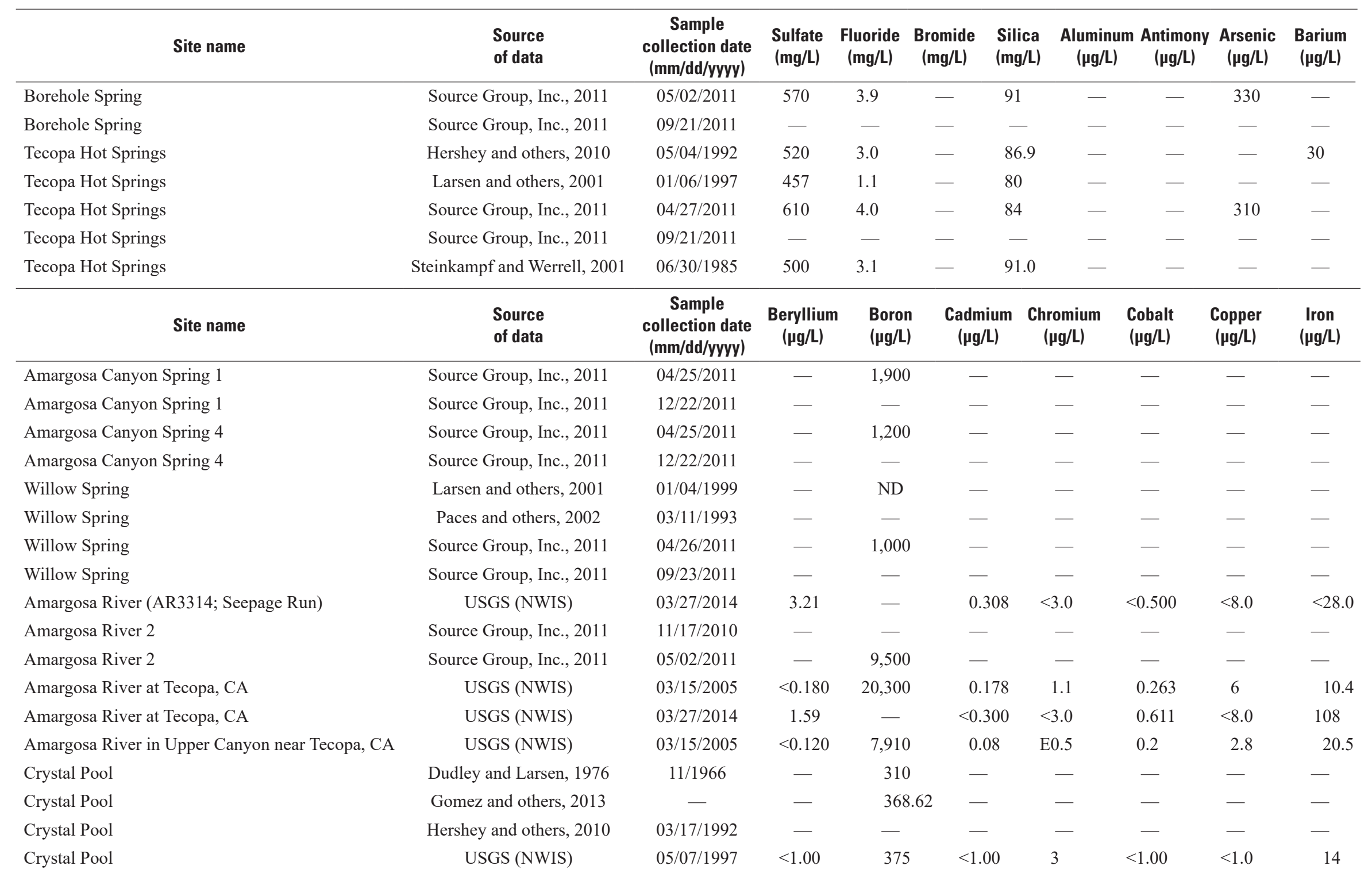


[All significant figures reflective of what was reported by sources. Data from the U.S. Geological Survey (USGS) from the USGS National Water Information System (NWIS) database. All analyses are assumed to be reported filtered values. Abbreviations: BLS, below land surface; CA, California; E, estimated value; $\mathrm{HCO}_{3}$, bicarbonate; IC, inductively coupled; ICP, inductively coupled plasma; ICP-MS, inductively coupled plasma-mass spectrometry; ID, identification; M, detected but not quantified; mg/L, milligram per liter; mm/dd/yyyy, month/day/year; NAD83, North American Datum of 1983; NA, not applicable; ND, not detected; pMC, percent modern carbon; R, radiochemical non-detect; TU, tritium unit; UTM, Universal Transverse Mercator; $\mu \mathrm{g} / \mathrm{L}$, microgram per liter; $\mu \mathrm{S} / \mathrm{cm}$, microsiemens pe centimeter; ${ }^{\circ} \mathrm{C}$, degrees Celsius; \%o, per mil; $\delta$, delta; <, less than; - , no data available]

\begin{tabular}{|c|c|c|c|c|c|c|c|c|c|}
\hline Site name & $\begin{array}{l}\text { Source } \\
\text { of data }\end{array}$ & $\begin{array}{c}\text { Sample } \\
\text { collection date } \\
\text { (mm/dd/yyyy) }\end{array}$ & $\begin{array}{l}\text { Beryllium } \\
(\mu \mathrm{g} / \mathrm{L})\end{array}$ & $\begin{array}{l}\text { Boron } \\
\text { ( } \mu \mathrm{g} / \mathrm{L})\end{array}$ & $\begin{array}{c}\text { Cadmium } \\
\text { ( } \mu \mathrm{g} / \mathrm{L})\end{array}$ & $\begin{array}{c}\text { Chromium } \\
(\mu \mathrm{g} / \mathrm{L})\end{array}$ & $\begin{array}{l}\text { Cobalt } \\
(\mu \mathrm{g} / \mathrm{L})\end{array}$ & $\begin{array}{c}\text { Copper } \\
\text { ( } \mu \mathrm{g} / \mathrm{L})\end{array}$ & $\begin{array}{l}\text { Iron } \\
(\mu \mathrm{g} / \mathrm{L})\end{array}$ \\
\hline Devils Hole (AM-4) & Thomas and others, 1996 & - & - & - & - & - & - & - & - \\
\hline Devils Hole (AM-4) & Gomez and others, 2013 & - & - & 296.86 & - & - & - & - & - \\
\hline Devils Hole (AM-4) & Hershey and others, 2010 & 07/09/1992 & - & - & - & - & - & - & - \\
\hline Devils Hole (AM-4) & USGS (NWIS) & 06/03/1984 & $<1$ & - & $<1$ & - & $<3$ & $<10$ & M \\
\hline Devils Hole (AM-4) & USGS (NWIS) & 06/03/1984 & $<1$ & - & $<1$ & - & $<3$ & $<10$ & 10 \\
\hline Devils Hole (AM-4) & USGS (NWIS) & 03/09/1985 & $<0.5$ & 350 & $<1$ & - & $<3$ & $<10$ & $<3$ \\
\hline Devils Hole (AM-4) & USGS (NWIS) & 03/09/1985 & $<0.5$ & 350 & $<1$ & - & $<3$ & $<10$ & $<3$ \\
\hline Devils Hole (AM-4) & USGS (NWIS) & 03/10/1985 & $<0.5$ & 350 & M & - & $<3$ & $<10$ & $<3$ \\
\hline Devils Hole (AM-4) & USGS (NWIS) & 05/05/1986 & - & - & - & - & - & - & - \\
\hline Devils Hole (AM-4) & USGS (NWIS) & 05/05/1986 & - & - & - & - & - & - & - \\
\hline Devils Hole (AM-4) & USGS (NWIS) & $11 / 16 / 1986$ & - & - & - & - & - & - & - \\
\hline Devils Hole (AM-4) & USGS (NWIS) & $11 / 16 / 1986$ & - & - & - & - & - & - & - \\
\hline Devils Hole (AM-4) & USGS (NWIS) & $06 / 22 / 1987$ & - & - & - & - & - & - & - \\
\hline Devils Hole (AM-4) & USGS (NWIS) & $06 / 22 / 1987$ & - & - & - & - & - & - & - \\
\hline Devils Hole (AM-4) & USGS (NWIS) & 03/16/1988 & - & - & - & - & - & - & - \\
\hline Devils Hole (AM-4) & USGS (NWIS) & 03/16/1988 & - & - & - & - & - & - & - \\
\hline Devils Hole (AM-4) & USGS (NWIS) & $12 / 07 / 1988$ & - & - & - & - & - & - & - \\
\hline Devils Hole (AM-4) & USGS (NWIS) & $12 / 07 / 1988$ & - & - & - & - & - & - & - \\
\hline Devils Hole (AM-4) & USGS (NWIS) & 06/21/1989 & - & - & - & - & - & - & - \\
\hline Devils Hole (AM-4) & USGS (NWIS) & 06/21/1989 & - & - & - & - & - & - & - \\
\hline Devils Hole (AM-4) & USGS (NWIS) & $06 / 25 / 1990$ & - & - & - & - & - & - & - \\
\hline Devils Hole (AM-4) & USGS (NWIS) & 06/25/1990 & - & - & - & - & - & - & - \\
\hline Devils Hole (AM-4) & USGS (NWIS) & $08 / 22 / 1990$ & - & - & $<10$ & 2 & - & $<10$ & 8 \\
\hline Devils Hole (AM-4) & USGS (NWIS) & 08/15/1991 & - & - & - & - & - & - & - \\
\hline Devils Hole (AM-4) & USGS (NWIS) & 08/27/1991 & - & - & $<10$ & $<1$ & - & $<10$ & $<3.0$ \\
\hline Devils Hole (AM-4) & USGS (NWIS) & 08/19/1992 & - & - & $<10$ & $<1$ & - & $<10$ & 6 \\
\hline Devils Hole (AM-4) & USGS (NWIS) & 08/18/1999 & $<1.00$ & 356 & $<1.00$ & $<1.0$ & $<1.00$ & $<1.0$ & $<10.0$ \\
\hline Devils Hole (AM-4) & USGS (NWIS) & 08/18/1999 & $<1.00$ & - & $<1.00$ & $<1.0$ & $<1.00$ & 2.7 & - \\
\hline
\end{tabular}


Table 9. Water chemistry of selected samples from the Lower Amargosa Valley and extra-basin contributing areas, California and Nevada.-Continued

[All significant figures reflective of what was reported by sources. Data from the U.S. Geological Survey (USGS) from the USGS National Water Information System (NWIS) database. All analyses are assumed to be reported filtered values. Abbreviations: BLS, below land surface; CA, California; E, estimated value; $\mathrm{HCO}_{3}$, bicarbonate; IC, inductively coupled; ICP, inductively coupled plasma;

ICP-MS, inductively coupled plasma-mass spectrometry; ID, identification; M, detected but not quantified; mg/L, milligram per liter; mm/dd/yyyy, month/day/year; NAD83, North American Datum of 1983; $\mathrm{NA}$, not applicable; ND, not detected; pMC, percent modern carbon; R, radiochemical non-detect; TU, tritium unit; UTM, Universal Transverse Mercator; $\mu \mathrm{g} / \mathrm{L}$, microgram per liter; $\mu \mathrm{S} / \mathrm{cm}$, microsiemens per centimeter; ${ }^{\circ} \mathrm{C}$, degrees Celsius; \%o, per mil; $\delta$, delta; $<$, less than; - , no data available]

\begin{tabular}{|c|c|c|c|c|c|c|c|c|c|}
\hline Site name & $\begin{array}{l}\text { Source } \\
\text { of data }\end{array}$ & $\begin{array}{c}\text { Sample } \\
\text { collection date } \\
\text { (mm/dd/yyyy) }\end{array}$ & $\begin{array}{c}\text { Beryllium } \\
\text { ( } \mu \mathrm{g} / \mathrm{L})\end{array}$ & $\begin{array}{l}\text { Boron } \\
\text { ( } \mu \mathrm{g} / \mathrm{L})\end{array}$ & $\begin{array}{c}\text { Cadmium } \\
\text { ( } \mu \mathrm{g} / \mathrm{L})\end{array}$ & $\begin{array}{c}\text { Chromium } \\
\text { ( } \mu \mathrm{g} / \mathrm{L})\end{array}$ & $\begin{array}{l}\text { Cobalt } \\
\text { ( } \mu \mathrm{g} / \mathrm{L})\end{array}$ & $\begin{array}{c}\text { Copper } \\
\text { ( } \mu \mathrm{g} / \mathrm{L})\end{array}$ & $\begin{array}{l}\text { Iron } \\
\text { ( } \mu \mathrm{g} / \mathrm{L})\end{array}$ \\
\hline Devils Hole (AM-4) & USGS (NWIS) & 08/18/1999 & - & - & - & - & - & - & - \\
\hline Devils Hole (AM-4) & USGS (NWIS) & 09/23/1999 & - & - & - & - & - & - & - \\
\hline Devils Hole (AM-4) & USGS (NWIS) & $09 / 10 / 2003$ & $<0.060$ & 333 & 0.204 & 5.6 & 0.095 & 2.5 & $<8.0$ \\
\hline Devils Hole (AM-4) & USGS (NWIS) & $09 / 10 / 2003$ & - & - & - & - & - & - & - \\
\hline Devils Hole (AM-4) & USGS (NWIS) & 09/27/2005 & $<0.060$ & 330 & 0.05 & 0.18 & 0.067 & 1.3 & E5.3 \\
\hline Devils Hole (AM-4) & USGS (NWIS) & $09 / 27 / 2005$ & - & - & - & - & - & - & - \\
\hline Fairbanks Spring & Dudley and Larsen, 1976 & $11 / 1966$ & - & 510 & - & - & - & - & - \\
\hline Fairbanks Spring & Gomez and others, 2013 & - & - & 364.33 & - & - & - & - & - \\
\hline Fairbanks Spring & Hershey and others, 2010 & 03/17/1992 & - & - & - & - & - & - & - \\
\hline Fairbanks Spring & Thomas and others, 1996 & - & - & - & - & - & - & - & - \\
\hline Fairbanks Spring & USGS (NWIS) & 05/06/1997 & $<1.00$ & - & - & 2 & $<1.00$ & 1.0 & 12.4 \\
\hline Five Springs well (AM-2) & Gomez and others, 2013 & - & - & 353.0 & - & - & - & - & - \\
\hline Five Springs well (AM-2) & Source Group, Inc., 2011 & 05/01/2011 & - & - & - & - & - & - & - \\
\hline Five Springs well (AM-2) & USGS (NWIS) & 08/24/1990 & - & - & $<10$ & $<1$ & - & $<10$ & 13 \\
\hline Five Springs well (AM-2) & USGS (NWIS) & 04/28/1992 & 1.00 & 150 & $<10$ & $<1$ & 1.00 & $<10$ & 10 \\
\hline Five Springs well (AM-2) & USGS (NWIS) & $10 / 18 / 1994$ & - & - & - & - & - & - & - \\
\hline Five Springs well (AM-2) & USGS (NWIS) & 09/22/1996 & - & - & - & - & - & - & - \\
\hline Hog Farm well & Zdon and Associates, 2014 & $04 / 25 / 2013$ & $<3.0$ & 1,800 & $<3.0$ & $<3.0$ & $<3.0$ & $<5.0$ & $<100$ \\
\hline Point of Rocks Spring & Gomez and others, 2013 & - & - & 280.0 & - & - & - & - & - \\
\hline Point of Rocks Spring & Hershey and others, 2010 & - & - & - & - & - & - & - & - \\
\hline Tule Spring & Hershey, 1989 & 06/30/1985 & - & - & - & - & - & - & - \\
\hline Tule Spring & USGS (NWIS) & $01 / 16 / 2013$ & 0.035 & - & $<0.016$ & $<0.07$ & 0.969 & $<0.80$ & 21.3 \\
\hline Resting Spring & Paces and others, 2002 & 03/11/1993 & - & - & - & - & - & - & - \\
\hline Resting Spring & Source Group, Inc., 2011 & $01 / 23 / 2011$ & - & - & - & - & - & - & - \\
\hline Resting Spring & Source Group, Inc., 2011 & $05 / 25 / 2011$ & - & - & - & - & - & - & 180 \\
\hline Twelvemile Spring & Zdon and Associates, 2014 & $04 / 25 / 2013$ & $<3.0$ & 1,400 & $<3.0$ & 14 & 5.3 & 12 & 11,000 \\
\hline Twelvemile Spring & Source Group, Inc., 2011 & $11 / 14 / 2010$ & - & - & - & - & - & - & - \\
\hline Twelvemile Spring & USGS (NWIS) & $03 / 21 / 2013$ & 0.071 & - & $<0.016$ & 0.1 & 0.042 & $<0.80$ & $<4.0$ \\
\hline
\end{tabular}


[All significant figures reflective of what was reported by sources. Data from the U.S. Geological Survey (USGS) from the USGS National Water Information System (NWIS) database. All analyses are assumed to be reported filtered values. Abbreviations: BLS, below land surface; CA, California; E, estimated value; $\mathrm{HCO}_{3}$, bicarbonate; IC, inductively coupled; ICP, inductively coupled plasma; ICP-MS, inductively coupled plasma-mass spectrometry; ID, identification; M, detected but not quantified; mg/L, milligram per liter; mm/dd/yyyy, month/day/year; NAD83, North American Datum of 1983; NA, not applicable; ND, not detected; pMC, percent modern carbon; R, radiochemical non-detect; TU, tritium unit; UTM, Universal Transverse Mercator; $\mu \mathrm{g} / \mathrm{L}$, microgram per liter; $\mu \mathrm{S} / \mathrm{cm}$, microsiemens pe centimeter; ${ }^{\circ} \mathrm{C}$, degrees Celsius; \%o, per mil; $\delta$, delta; $<$, less than; - , no data available]

\begin{tabular}{|c|c|c|c|c|c|c|c|c|c|}
\hline Site name & $\begin{array}{l}\text { Source } \\
\text { of data }\end{array}$ & $\begin{array}{c}\text { Sample } \\
\text { collection date } \\
\text { (mm/dd/yyyy) }\end{array}$ & $\begin{array}{c}\text { Beryllium } \\
\text { ( } \mu \mathrm{g} / \mathrm{L})\end{array}$ & $\begin{array}{l}\text { Boron } \\
\text { ( } \mu \mathrm{g} / \mathrm{L})\end{array}$ & $\begin{array}{c}\text { Cadmium } \\
(\mu \mathrm{g} / \mathrm{L})\end{array}$ & $\begin{array}{l}\text { Chromium } \\
(\mu \mathrm{g} / \mathrm{L})\end{array}$ & $\begin{array}{l}\text { Cobalt } \\
\text { ( } \mu \mathrm{g} / \mathrm{L})\end{array}$ & $\begin{array}{c}\text { Copper } \\
\text { ( } \mu \mathrm{g} / \mathrm{L})\end{array}$ & $\begin{array}{l}\text { Iron } \\
(\mu \mathrm{g} / \mathrm{L})\end{array}$ \\
\hline Salsberry Spring & Paces and others, 2002 & 06/17/1998 & - & - & - & - & - & - & - \\
\hline Salsberry Spring & USGS (NWIS) & $03 / 11 / 2013$ & 0.325 & - & 0.047 & 0.351 & 2.94 & 3.10 & 470 \\
\hline Crystal Spring & Drakos and Hodgins, 2013 & $03 / 14 / 2012$ & - & - & - & - & - & - & - \\
\hline Crystal Spring & Paces and others, 2002 & 02/05/1990 & - & - & - & - & - & - & - \\
\hline Crystal Spring & Zdon and Associates, 2014 & $04 / 26 / 2011$ & - & - & - & - & - & - & - \\
\hline Crystal Spring & Zdon and Associates, 2014 & $04 / 27 / 2011$ & - & 180 & - & - & - & - & - \\
\hline Crystal Spring & USGS (NWIS) & 08/10/1994 & - & - & - & - & - & - & - \\
\hline Crystal Spring & USGS (NWIS) & 08/10/1994 & - & - & - & - & - & - & 120 \\
\hline Crystal Spring & USGS (NWIS) & 09/23/1996 & - & - & - & - & - & - & - \\
\hline Crystal Spring & USGS (NWIS) & 07/27/1998 & 0.50 & 610 & 1.00 & 5.00 & 3.00 & 10.0 & 7 \\
\hline Nevada National Security Site well & Gomez and others, 2013 & - & - & - & - & - & - & - & - \\
\hline 162 S20 E 5323 ABAD1 U19 & USGS (NWIS) & $11 / 07 / 2013$ & $<0.020$ & 28 & $<0.030$ & 0.56 & $<0.050$ & 1.1 & $<4.0$ \\
\hline Hidden Hills Ranch well & Hershey, 1989 & 07/30/1987 & - & - & - & - & - & - & 10 \\
\hline Jeep Trail well & Drakos and Hodgins, 2013 & 03/16/2012 & - & - & - & - & - & - & - \\
\hline NC-GWE-PV-04 & USGS (NWIS) & $06 / 27 / 2012$ & - & - & - & - & - & - & - \\
\hline NC-GWE-PV-04 & USGS (NWIS) & $10 / 15 / 2012$ & $<0.006$ & - & $<0.016$ & 3 & 0.038 & $<0.80$ & $<4.0$ \\
\hline Stump Spring well & Drakos and Hodgins, 2013 & $02 / 28 / 2012$ & - & - & - & - & - & - & - \\
\hline Stump Spring well & USGS (NWIS) & $06 / 22 / 2009$ & $<0.020$ & 32 & 0.05 & 4.7 & $<1.4$ & 1.3 & E2.2 \\
\hline Stump Spring well & USGS (NWIS) & $05 / 20 / 2010$ & - & - & - & - & - & - & - \\
\hline Black Mountain precipitation & USGS (NWIS) & $03 / 11 / 2013$ & - & - & - & - & - & - & - \\
\hline Kingston Range precipitation & USGS (NWIS) & $01 / 16 / 2013$ & - & - & - & - & - & - & - \\
\hline Mt Charleston precipitation & USGS (NWIS) & $05 / 23 / 2013$ & - & - & - & - & - & - & - \\
\hline Nopah Range precipitation & USGS (NWIS) & 03/19/2013 & - & - & - & - & - & - & - \\
\hline Borax Spring & Larsen and others, 2001 & 01/03/1999 & - & ND & - & - & - & - & - \\
\hline Borax Spring & Source Group, Inc., 2011 & $04 / 27 / 2011$ & - & 130,000 & - & - & - & - & - \\
\hline Borax Spring & Source Group, Inc., 2011 & $09 / 21 / 2011$ & - & - & - & - & - & - & - \\
\hline Chappo Spring & Paces and others, 2002 & 03/12/1993 & - & - & - & - & - & - & - \\
\hline Chappo Spring & Source Group, Inc., 2011 & $05 / 01 / 2011$ & - & 2,000 & - & - & - & - & - \\
\hline Chappo Spring & Larsen and others, 2001 & 01/05/1999 & - & 1,800 & - & - & - & - & - \\
\hline
\end{tabular}


Table 9. Water chemistry of selected samples from the Lower Amargosa Valley and extra-basin contributing areas, California and Nevada.-Continued

[All significant figures reflective of what was reported by sources. Data from the U.S. Geological Survey (USGS) from the USGS National Water Information System (NWIS) database. All analyses are assumed to be reported filtered values. Abbreviations: BLS, below land surface; CA, California; E, estimated value; $\mathrm{HCO}_{3}$, bicarbonate; IC, inductively coupled; ICP, inductively coupled plasma;

ICP-MS, inductively coupled plasma-mass spectrometry; ID, identification; M, detected but not quantified; mg/L, milligram per liter; mm/dd/yyyy, month/day/year; NAD83, North American Datum of 1983; $\mathrm{NA}$, not applicable; ND, not detected; pMC, percent modern carbon; R, radiochemical non-detect; TU, tritium unit; UTM, Universal Transverse Mercator; $\mu \mathrm{g} / \mathrm{L}$, microgram per liter; $\mu \mathrm{S} / \mathrm{cm}$, microsiemens per centimeter; ${ }^{\circ} \mathrm{C}$, degrees Celsius; \%o, per mil; $\delta$, delta; $<$, less than; - , no data available]

\begin{tabular}{|c|c|c|c|c|c|c|c|c|c|}
\hline Site name & $\begin{array}{l}\text { Source } \\
\text { of data }\end{array}$ & $\begin{array}{c}\text { Sample } \\
\text { collection date } \\
\text { (mm/dd/yyyy) }\end{array}$ & $\begin{array}{c}\text { Beryllium } \\
\text { ( } \mu \mathrm{g} / \mathrm{L})\end{array}$ & $\begin{array}{l}\text { Boron } \\
(\mu g / L)\end{array}$ & $\begin{array}{c}\text { Cadmium } \\
(\mu \mathrm{g} / \mathrm{L})\end{array}$ & $\begin{array}{c}\text { Chromium } \\
(\mu \mathrm{g} / \mathrm{L})\end{array}$ & $\begin{array}{l}\text { Cobalt } \\
\text { ( } \mu \mathrm{g} / \mathrm{L} \text { ) }\end{array}$ & $\begin{array}{c}\text { Copper } \\
\text { ( } \mu g / L)\end{array}$ & $\begin{array}{l}\text { Iron } \\
(\mu \mathrm{g} / \mathrm{L})\end{array}$ \\
\hline Cynthia's well & Zdon and Associates, 2014 & $04 / 25 / 2013$ & $<3.0$ & 880 & $<3.0$ & $<3.0$ & $<3.0$ & $<5.0$ & $<100$ \\
\hline Cynthia's well & Source Group, Inc., 2011 & $05 / 11 / 2011$ & - & 1,400 & - & - & - & - & 320 \\
\hline Cynthia's well & Zdon and Associates, 2014 & $01 / 16 / 2011$ & - & - & - & - & - & - & - \\
\hline Shoshone Spring & Larsen and others, 2001 & $01 / 16 / 1962$ & - & - & - & - & - & - & - \\
\hline Shoshone Spring & Larsen and others, 2001 & $02 / 27 / 1976$ & - & 4,000 & - & - & - & - & - \\
\hline Shoshone Spring & Larsen and others, 2001 & 01/06/1997 & - & 4,200 & - & - & - & - & - \\
\hline Shoshone Spring & Source Group, Inc., 2011 & $01 / 23 / 2011$ & - & - & - & - & - & - & - \\
\hline Shoshone Spring & Source Group, Inc., 2011 & $04 / 27 / 2011$ & - & 4,200 & - & - & - & - & - \\
\hline Shoshone Spring & USGS (NWIS) & 03/10/1998 & - & - & - & - & - & - & - \\
\hline Thom Spring & Source Group, Inc., 2011 & $11 / 11 / 2010$ & - & - & - & - & - & - & - \\
\hline Thom Spring & Source Group, Inc., 2011 & $04 / 27 / 2011$ & - & 5,300 & - & - & - & - & 290 \\
\hline Wild Bath Spring & USGS (NWIS) & $06 / 10 / 1998$ & - & - & - & - & - & - & - \\
\hline Wild Bath Spring & Source Group, Inc., 2011 & $04 / 27 / 2011$ & - & 6,500 & - & - & - & - & - \\
\hline Wild Bath Spring & Source Group, Inc., 2011 & $09 / 21 / 2011$ & - & - & - & - & - & - & - \\
\hline Willow Spring & Hershey, 1989 & $06 / 26 / 1985$ & - & - & - & - & - & - & 1,020 \\
\hline Horse Springs & Drakos and Hodgins, 2013 & $03 / 05 / 2012$ & - & - & - & - & - & - & - \\
\hline Horse Springs & Paces and others, 2002 & $06 / 23 / 1993$ & - & - & - & - & - & - & - \\
\hline Lost Cabin Spring & Hershey, 1989 & $06 / 17 / 1987$ & - & - & - & - & - & - & - \\
\hline Lost Cabin Spring & USGS (NWIS) & $07 / 21 / 2009$ & - & - & - & - & - & - & - \\
\hline Lost Cabin Spring & USGS (NWIS) & $12 / 28 / 2009$ & $<0.012$ & 113 & $<0.020$ & E0.08 & 0.117 & $<1.0$ & E4.1 \\
\hline Lost Cabin Spring & USGS (NWIS) & $07 / 23 / 2010$ & - & - & - & - & - & - & 9.9 \\
\hline Peak Spring & Hershey, 1989 & $06 / 23 / 1987$ & - & - & - & - & - & - & - \\
\hline Peak Spring & USGS (NWIS) & $09 / 03 / 2008$ & $<0.008$ & 8.6 & $<0.040$ & 0.44 & $<1.4$ & $<1.0$ & $<8.0$ \\
\hline Peak Spring & USGS (NWIS) & $07 / 27 / 2009$ & - & - & - & - & - & - & - \\
\hline Peak Spring & USGS (NWIS) & $08 / 10 / 2010$ & - & - & - & - & - & - & $<6.0$ \\
\hline Rainbow Spring & Hershey, 1989 & 09/19/1982 & - & - & - & - & - & - & - \\
\hline Rainbow Spring & Paces and others, 2002 & $06 / 23 / 1993$ & - & - & - & - & - & - & - \\
\hline Borehole Spring & Source Group, Inc., 2011 & $05 / 02 / 2011$ & - & 9,200 & - & - & - & - & 320 \\
\hline Borehole Spring & Source Group, Inc., 2011 & $09 / 21 / 2011$ & - & - & - & - & - & - & - \\
\hline
\end{tabular}


[All significant figures reflective of what was reported by sources. Data from the U.S. Geological Survey (USGS) from the USGS National Water Information System (NWIS) database. All analyses are assumed to be reported filtered values. Abbreviations: BLS, below land surface; CA, California; E, estimated value; $\mathrm{HCO}_{3}$, bicarbonate; IC, inductively coupled; ICP, inductively coupled plasma; ICP-MS, inductively coupled plasma-mass spectrometry; ID, identification; M, detected but not quantified; mg/L, milligram per liter; mm/dd/yyyy, month/day/year; NAD83, North American Datum of 1983; NA, not applicable; ND, not detected; pMC, percent modern carbon; R, radiochemical non-detect; TU, tritium unit; UTM, Universal Transverse Mercator; $\mu \mathrm{g} / \mathrm{L}$, microgram per liter; $\mu \mathrm{S} / \mathrm{cm}$, microsiemens pe centimeter; ${ }^{\circ} \mathrm{C}$, degrees Celsius; \%o, per mil; $\delta$, delta; <, less than; - , no data available]

\begin{tabular}{|c|c|c|c|c|c|c|c|c|c|}
\hline Site name & $\begin{array}{l}\text { Source } \\
\text { of data }\end{array}$ & $\begin{array}{c}\text { Sample } \\
\text { collection date } \\
\text { (mm/dd/yyyy) }\end{array}$ & $\begin{array}{c}\text { Beryllium } \\
\text { ( } \mu \mathrm{g} / \mathrm{L})\end{array}$ & $\begin{array}{l}\text { Boron } \\
(\mu \mathrm{g} / \mathrm{L})\end{array}$ & $\begin{array}{c}\text { Cadmium } \\
\text { ( } \mu \mathrm{g} / \mathrm{L})\end{array}$ & $\begin{array}{c}\text { Chromium } \\
(\mu \mathrm{g} / \mathrm{L})\end{array}$ & $\begin{array}{l}\text { Cobalt } \\
\text { ( } \mu \mathrm{g} / \mathrm{L})\end{array}$ & $\begin{array}{l}\text { Copper } \\
\text { ( } \mu \mathrm{g} / \mathrm{L})\end{array}$ & $\begin{array}{l}\text { Iron } \\
\text { ( } \mu \mathrm{g} / \mathrm{L})\end{array}$ \\
\hline Tecopa Hot Springs & Hershey and others, 2009 & $05 / 04 / 1992$ & - & - & - & - & - & - & - \\
\hline Tecopa Hot Springs & Larsen and others, 2001 & 01/06/1997 & - & 8,000 & - & - & - & - & - \\
\hline Tecopa Hot Springs & Source Group, Inc., 2011 & $04 / 27 / 2011$ & - & 11,000 & - & - & - & - & - \\
\hline Tecopa Hot Springs & Source Group, Inc., 2011 & $09 / 21 / 2011$ & - & - & - & - & - & - & - \\
\hline Tecopa Hot Springs & Steinkampf and Werrell, 2001 & 06/30/1985 & - & - & - & - & - & - & - \\
\hline Site name & $\begin{array}{l}\text { Source } \\
\text { of data }\end{array}$ & $\begin{array}{c}\text { Sample } \\
\text { collection date } \\
\text { (mm/dd/yyyy) }\end{array}$ & $\begin{array}{l}\text { Lead } \\
\text { ( } \mu \mathrm{g} / \mathrm{L})\end{array}$ & $\begin{array}{l}\text { Lithium } \\
\text { ( } \mu \mathrm{g} / \mathrm{L})\end{array}$ & $\begin{array}{c}\text { Manganese } \\
(\mu \mathrm{g} / \mathrm{L})\end{array}$ & $\begin{array}{l}\text { Molybdenum } \\
\text { ( } \mu \mathrm{g} / \mathrm{L})\end{array}$ & $\begin{array}{c}\text { Nickel } \\
\text { (pg/L) }\end{array}$ & $\begin{array}{l}\text { Selenium } \\
(\mu \mathrm{g} / \mathrm{L})\end{array}$ & $\begin{array}{c}\text { Strontium } \\
(\mu \mathrm{g} / \mathrm{L})\end{array}$ \\
\hline Amargosa Canyon Spring 1 & Source Group, Inc., 2011 & $04 / 25 / 2011$ & - & - & - & - & - & - & 1,187 \\
\hline Amargosa Canyon Spring 1 & Source Group, Inc., 2011 & $12 / 22 / 2011$ & - & - & - & - & - & - & - \\
\hline Amargosa Canyon Spring 4 & Source Group, Inc., 2011 & $04 / 25 / 2011$ & - & - & - & - & - & - & 1,109 \\
\hline Amargosa Canyon Spring 4 & Source Group, Inc., 2011 & $12 / 22 / 2011$ & - & - & - & - & - & - & - \\
\hline Willow Spring & Larsen and others, 2001 & 01/04/1999 & - & - & - & - & - & - & - \\
\hline Willow Spring & Paces and others, 2002 & 03/11/1993 & - & - & - & - & - & - & - \\
\hline Willow Spring & Source Group, Inc., 2011 & $04 / 26 / 2011$ & - & - & - & - & - & - & 1,466 \\
\hline Willow Spring & Source Group, Inc., 2011 & $09 / 23 / 2011$ & - & - & - & - & - & - & - \\
\hline Amargosa River (AR3314; Seepage Run) & USGS (NWIS) & $03 / 27 / 2014$ & $<0.400$ & - & 5.51 & 118 & $<2.0$ & 1.2 & 2,700 \\
\hline Amargosa River 2 & Source Group, Inc., 2011 & $11 / 17 / 2010$ & - & - & - & - & - & - & - \\
\hline Amargosa River 2 & Source Group, Inc., 2011 & $05 / 02 / 2011$ & - & - & - & - & - & - & 3,800 \\
\hline Amargosa River at Tecopa, CA & USGS (NWIS) & $03 / 15 / 2005$ & 0.231 & - & 5.05 & 82.8 & 1.11 & - & - \\
\hline Amargosa River at Tecopa, CA & USGS (NWIS) & $03 / 27 / 2014$ & $<0.400$ & - & 8.28 & 63.9 & $<2.0$ & $<0.50$ & 703 \\
\hline Amargosa River in Upper Canyon near Tecopa, CA & USGS (NWIS) & $03 / 15 / 2005$ & 0.22 & - & 85.8 & 40.6 & 0.98 & 1 & - \\
\hline Crystal Pool & Dudley and Larsen, 1976 & $11 / 1966$ & - & 90 & - & - & - & - & - \\
\hline Crystal Pool & Gomez and others, 2013 & - & - & 88.60 & - & - & - & - & 942.23 \\
\hline Crystal Pool & Hershey and others, 2010 & 03/17/1992 & - & 30 & - & - & - & - & 230 \\
\hline Crystal Pool & USGS (NWIS) & 05/07/1997 & $<1.00$ & - & $<1.00$ & 7.77 & $<1.00$ & $<1$ & 933 \\
\hline Devils Hole (AM-4) & Thomas and others, 1996 & - & - & - & - & - & - & - & - \\
\hline Devils Hole (AM-4) & Gomez and others, 2013 & - & - & 83.13 & - & - & - & - & 804.63 \\
\hline
\end{tabular}


Table 9. Water chemistry of selected samples from the Lower Amargosa Valley and extra-basin contributing areas, California and Nevada.-Continued

[All significant figures reflective of what was reported by sources. Data from the U.S. Geological Survey (USGS) from the USGS National Water Information System (NWIS) database. All analyses are assumed to be reported filtered values. Abbreviations: BLS, below land surface; CA, California; E, estimated value; $\mathrm{HCO}_{3}$, bicarbonate; IC, inductively coupled; ICP, inductively coupled plasma;

ICP-MS, inductively coupled plasma-mass spectrometry; ID, identification; M, detected but not quantified; mg/L, milligram per liter; mm/dd/yyyy, month/day/year; NAD83, North American Datum of 1983; $\mathrm{NA}$, not applicable; ND, not detected; pMC, percent modern carbon; R, radiochemical non-detect; TU, tritium unit; UTM, Universal Transverse Mercator; $\mu \mathrm{g} / \mathrm{L}$, microgram per liter; $\mu \mathrm{S} / \mathrm{cm}$, microsiemens per centimeter; ${ }^{\circ} \mathrm{C}$, degrees Celsius; \%o, per mil; $\delta$, delta; $<$, less than; - , no data available]

\begin{tabular}{|c|c|c|c|c|c|c|c|c|c|}
\hline Site name & $\begin{array}{l}\text { Source } \\
\text { of data }\end{array}$ & $\begin{array}{c}\text { Sample } \\
\text { collection date } \\
\text { (mm/dd/yyyy) }\end{array}$ & $\begin{array}{l}\text { Lead } \\
\text { ( } \mu \mathrm{g} / \mathrm{L})\end{array}$ & $\begin{array}{l}\text { Lithium } \\
\text { ( } \mu \mathrm{g} / \mathrm{L})\end{array}$ & $\begin{array}{c}\text { Manganese } \\
(\mu \mathrm{g} / \mathrm{L})\end{array}$ & $\begin{array}{l}\text { Molybdenum } \\
\text { ( } \mu \mathrm{g} / \mathrm{L})\end{array}$ & $\begin{array}{c}\text { Nickel } \\
(\mu \mathrm{g} / \mathrm{L})\end{array}$ & $\begin{array}{l}\text { Selenium } \\
(\mu \mathrm{g} / \mathrm{L})\end{array}$ & $\begin{array}{c}\text { Strontium } \\
(\mu \mathrm{g} / \mathrm{L})\end{array}$ \\
\hline Devils Hole (AM-4) & Hershey and others, 2009 & 07/09/1992 & - & 90 & - & - & - & - & 850 \\
\hline Devils Hole (AM-4) & USGS (NWIS) & 06/03/1984 & $<10$ & 90 & $<1$ & $<10$ & - & - & 890 \\
\hline Devils Hole (AM-4) & USGS (NWIS) & 06/03/1984 & $<10$ & 90 & $<1$ & $<10$ & - & - & 880 \\
\hline Devils Hole (AM-4) & USGS (NWIS) & 03/09/1985 & $<10$ & 80 & M & $<10$ & - & - & 890 \\
\hline Devils Hole (AM-4) & USGS (NWIS) & 03/09/1985 & $<10$ & 80 & M & $<10$ & - & - & 890 \\
\hline Devils Hole (AM-4) & USGS (NWIS) & 03/10/1985 & $<10$ & 80 & M & $<10$ & - & - & 890 \\
\hline Devils Hole (AM-4) & USGS (NWIS) & 05/05/1986 & - & - & - & - & - & - & - \\
\hline Devils Hole (AM-4) & USGS (NWIS) & 05/05/1986 & - & - & - & - & - & - & - \\
\hline Devils Hole (AM-4) & USGS (NWIS) & $11 / 16 / 1986$ & - & - & - & - & - & - & - \\
\hline Devils Hole (AM-4) & USGS (NWIS) & $11 / 16 / 1986$ & - & - & - & - & - & - & - \\
\hline Devils Hole (AM-4) & USGS (NWIS) & 06/22/1987 & - & - & - & - & - & - & - \\
\hline Devils Hole (AM-4) & USGS (NWIS) & 06/22/1987 & - & - & - & - & - & - & - \\
\hline Devils Hole (AM-4) & USGS (NWIS) & 03/16/1988 & - & - & - & - & - & - & - \\
\hline Devils Hole (AM-4) & USGS (NWIS) & 03/16/1988 & - & - & - & - & - & - & - \\
\hline Devils Hole (AM-4) & USGS (NWIS) & $12 / 07 / 1988$ & - & - & - & - & - & - & - \\
\hline Devils Hole (AM-4) & USGS (NWIS) & $12 / 07 / 1988$ & - & - & - & - & - & - & - \\
\hline Devils Hole (AM-4) & USGS (NWIS) & 06/21/1989 & - & - & - & - & - & - & - \\
\hline Devils Hole (AM-4) & USGS (NWIS) & 06/21/1989 & - & - & - & - & - & - & - \\
\hline Devils Hole (AM-4) & USGS (NWIS) & 06/25/1990 & - & - & - & - & - & - & - \\
\hline Devils Hole (AM-4) & USGS (NWIS) & 06/25/1990 & - & - & - & - & - & - & - \\
\hline Devils Hole (AM-4) & USGS (NWIS) & 08/22/1990 & $<100$ & - & $<1.00$ & - & - & $<1$ & - \\
\hline Devils Hole (AM-4) & USGS (NWIS) & 08/15/1991 & - & - & - & - & - & - & - \\
\hline Devils Hole (AM-4) & USGS (NWIS) & 08/27/1991 & $<100$ & - & $<1.00$ & - & - & $<1$ & - \\
\hline Devils Hole (AM-4) & USGS (NWIS) & 08/19/1992 & $<100$ & - & $<1.00$ & - & - & $<1$ & - \\
\hline Devils Hole (AM-4) & USGS (NWIS) & 08/18/1999 & $<1.00$ & - & $<1.00$ & 6.78 & 1.23 & $<1$ & 878 \\
\hline Devils Hole (AM-4) & USGS (NWIS) & 08/18/1999 & $<1.00$ & - & $<1.00$ & 6.59 & 1.48 & $<1$ & - \\
\hline Devils Hole (AM-4) & USGS (NWIS) & 08/18/1999 & - & - & - & - & - & - & - \\
\hline Devils Hole (AM-4) & USGS (NWIS) & 09/23/1999 & - & - & - & - & - & - & - \\
\hline
\end{tabular}


[All significant figures reflective of what was reported by sources. Data from the U.S. Geological Survey (USGS) from the USGS National Water Information System (NWIS) database. All analyses are assumed to be reported filtered values. Abbreviations: BLS, below land surface; CA, California; E, estimated value; $\mathrm{HCO}_{3}$, bicarbonate; IC, inductively coupled; ICP, inductively coupled plasma; ICP-MS, inductively coupled plasma-mass spectrometry; ID, identification; M, detected but not quantified; mg/L, milligram per liter; mm/dd/yyyy, month/day/year; NAD83, North American Datum of 1983; NA, not applicable; ND, not detected; pMC, percent modern carbon; R, radiochemical non-detect; TU, tritium unit; UTM, Universal Transverse Mercator; $\mu \mathrm{g} / \mathrm{L}$, microgram per liter; $\mu \mathrm{S} / \mathrm{cm}$, microsiemens per centimeter; ${ }^{\circ} \mathrm{C}$, degrees Celsius; $\%$, per mil; $\delta$, delta; $<$, less than; - , no data available]

\begin{tabular}{|c|c|c|c|c|c|c|c|c|c|}
\hline Site name & $\begin{array}{l}\text { Source } \\
\text { of data }\end{array}$ & $\begin{array}{c}\text { Sample } \\
\text { collection date } \\
\text { (mm/dd/yyyy) }\end{array}$ & $\begin{array}{l}\text { Lead } \\
\text { ( } \mu g / L)\end{array}$ & $\begin{array}{l}\text { Lithium } \\
\text { ( } \mu \mathrm{g} / \mathrm{L} \text { ) }\end{array}$ & $\begin{array}{c}\text { Manganese } \\
(\mu \mathrm{g} / \mathrm{L})\end{array}$ & $\begin{array}{l}\text { Molybdenum } \\
\text { ( } \mu \mathrm{g} / \mathrm{L})\end{array}$ & $\begin{array}{l}\text { Nickel } \\
(\mu \mathrm{g} / \mathrm{L})\end{array}$ & $\begin{array}{l}\text { Selenium } \\
\text { ( } \mu \mathrm{g} / \mathrm{L})\end{array}$ & $\begin{array}{c}\text { Strontium } \\
\text { ( } \mu \mathrm{g} / \mathrm{L})\end{array}$ \\
\hline Devils Hole (AM-4) & USGS (NWIS) & $09 / 10 / 2003$ & $<0.080$ & - & E0.15 & 6.73 & 0.72 & E2 & - \\
\hline Devils Hole (AM-4) & USGS (NWIS) & 09/10/2003 & - & - & - & - & - & - & - \\
\hline Devils Hole (AM-4) & USGS (NWIS) & 09/27/2005 & E0.050 & - & 0.33 & 6.44 & 0.93 & 0.86 & - \\
\hline Devils Hole (AM-4) & USGS (NWIS) & 09/27/2005 & - & - & - & - & - & - & - \\
\hline Fairbanks Spring & Dudley and Larsen, 1976 & $11 / 1966$ & - & 90 & - & - & - & - & - \\
\hline Fairbanks Spring & Gomez and others, 2013 & - & - & 89.67 & - & - & - & - & 825.68 \\
\hline Fairbanks Spring & Hershey and others, 2010 & 03/17/1992 & - & 90 & - & - & - & - & 850 \\
\hline Fairbanks Spring & Thomas and others, 1996 & - & - & - & - & - & - & - & - \\
\hline Fairbanks Spring & USGS (NWIS) & 05/06/1997 & - & - & $<1.00$ & 7.43 & $<1.00$ & $<1$ & 857 \\
\hline Five Springs well (AM-2) & Gomez and others, 2013 & - & - & 84.0 & - & - & - & - & 863.33 \\
\hline Five Springs well (AM-2) & Source Group, Inc., 2011 & 05/01/2011 & - & - & $<1$ & - & - & - & 860 \\
\hline Five Springs well (AM-2) & USGS (NWIS) & $08 / 24 / 1990$ & $<100$ & - & $<1$ & - & - & $<1$ & - \\
\hline Five Springs well (AM-2) & USGS (NWIS) & 04/28/1992 & $<100$ & - & 1.00 & 5.60 & 1.37 & $<1$ & - \\
\hline Five Springs well (AM-2) & USGS (NWIS) & 10/18/1994 & - & - & - & - & - & - & - \\
\hline Five Springs well (AM-2) & USGS (NWIS) & 09/22/1996 & - & - & - & - & - & - & - \\
\hline Hog Farm well & Zdon and Associates, 2014 & $04 / 25 / 2013$ & $<5.0$ & $<100$ & $<500$ & 14 & $<5.0$ & $<10$ & 150 \\
\hline Point of Rocks Spring & Gomez and others, 2013 & - & - & 88.33 & - & - & - & - & 833.33 \\
\hline Point of Rocks Spring & Hershey and others, 2010 & - & - & - & - & - & - & - & - \\
\hline Tule Spring & Hershey, 1989 & 06/30/1985 & - & - & - & - & - & - & - \\
\hline Tule Spring & USGS (NWIS) & $01 / 16 / 2013$ & 0.056 & - & 30.9 & 4.47 & 0.47 & 0.12 & 1,670 \\
\hline Resting Spring & Paces and others, 2002 & 03/11/1993 & - & - & - & - & - & - & - \\
\hline Resting Spring & Source Group, Inc., 2011 & $01 / 23 / 2011$ & - & - & - & - & - & - & - \\
\hline Resting Spring & Source Group, Inc., 2011 & $05 / 25 / 2011$ & - & - & - & - & - & - & 978 \\
\hline Twelvemile Spring & Zdon and Associates, 2014 & $04 / 25 / 2013$ & 6.6 & 130 & $<500$ & $<50$ & 9.8 & $<10$ & 1,000 \\
\hline Twelvemile Spring & Source Group, Inc., 2011 & $11 / 14 / 2010$ & - & - & - & - & - & - & - \\
\hline Twelvemile Spring & USGS (NWIS) & $03 / 21 / 2013$ & 0.031 & - & 1.12 & 5.6 & 0.29 & 0.12 & 1,030 \\
\hline Salsberry Spring & Paces and others, 2002 & 06/17/1998 & - & - & - & - & - & - & - \\
\hline Salsberry Spring & USGS (NWIS) & $03 / 11 / 2013$ & 1.54 & - & 15.1 & 1.33 & 1.21 & 0.301 & 62 \\
\hline
\end{tabular}


Table 9. Water chemistry of selected samples from the Lower Amargosa Valley and extra-basin contributing areas, California and Nevada.-Continued

[All significant figures reflective of what was reported by sources. Data from the U.S. Geological Survey (USGS) from the USGS National Water Information System (NWIS) database. All analyses are assumed to be reported filtered values. Abbreviations: BLS, below land surface; CA, California; E, estimated value; $\mathrm{HCO}_{3}$, bicarbonate; IC, inductively coupled; ICP, inductively coupled plasma;

ICP-MS, inductively coupled plasma-mass spectrometry; ID, identification; M, detected but not quantified; mg/L, milligram per liter; mm/dd/yyyy, month/day/year; NAD83, North American Datum of 1983; $\mathrm{NA}$, not applicable; ND, not detected; pMC, percent modern carbon; R, radiochemical non-detect; TU, tritium unit; UTM, Universal Transverse Mercator; $\mu \mathrm{g} / \mathrm{L}$, microgram per liter; $\mu \mathrm{S} / \mathrm{cm}$, microsiemens per centimeter; ${ }^{\circ} \mathrm{C}$, degrees Celsius; \%o, per mil; $\delta$, delta; $<$, less than; - , no data available]

\begin{tabular}{|c|c|c|c|c|c|c|c|c|c|}
\hline Site name & $\begin{array}{l}\text { Source } \\
\text { of data }\end{array}$ & $\begin{array}{c}\text { Sample } \\
\text { collection date } \\
\text { (mm/dd/yyyy) }\end{array}$ & $\begin{array}{l}\text { Lead } \\
\text { ( } \mu \mathrm{g} / \mathrm{L})\end{array}$ & $\begin{array}{c}\text { Lithium } \\
\text { ( } \mu \mathrm{g} / \mathrm{L})\end{array}$ & $\begin{array}{c}\text { Manganese } \\
(\mu \mathrm{g} / \mathrm{L})\end{array}$ & $\begin{array}{c}\text { Molybdenum } \\
(\mu \mathrm{g} / \mathrm{L})\end{array}$ & $\begin{array}{l}\text { Nickel } \\
(\mu \mathrm{g} / \mathrm{L})\end{array}$ & $\begin{array}{l}\text { Selenium } \\
(\mu \mathrm{g} / \mathrm{L})\end{array}$ & $\begin{array}{c}\text { Strontium } \\
(\mu \mathrm{g} / \mathrm{L})\end{array}$ \\
\hline Crystal Spring & Drakos and Hodgins, 2013 & $03 / 14 / 2012$ & - & - & - & - & - & - & 300 \\
\hline Crystal Spring & Paces and others, 2002 & 02/05/1990 & - & - & - & - & - & - & - \\
\hline Crystal Spring & Zdon and Associates, 2014 & $04 / 26 / 2011$ & - & - & - & - & - & - & - \\
\hline Crystal Spring & Zdon and Associates, 2014 & $04 / 27 / 2011$ & - & - & - & - & - & - & 281 \\
\hline Crystal Spring & USGS (NWIS) & 08/10/1994 & - & - & - & - & - & - & - \\
\hline Crystal Spring & USGS (NWIS) & 08/10/1994 & - & 70 & 10 & - & - & - & 530 \\
\hline Crystal Spring & USGS (NWIS) & 09/23/1996 & - & - & - & - & - & - & 3 \\
\hline Crystal Spring & USGS (NWIS) & 07/27/1998 & 10.0 & - & 330 & 10.0 & 20.0 & - & 690 \\
\hline Nevada National Security Site well & Gomez and others, 2013 & - & - & - & - & - & - & - & 198.33 \\
\hline 162 S20 E 5323 ABAD1 U19 & USGS (NWIS) & $11 / 07 / 2013$ & 0.126 & 5 & $<0.40$ & 0.498 & 0.38 & 0.56 & 344 \\
\hline Hidden Hills Ranch well & Hershey, 1989 & 07/30/1987 & - & - & - & - & - & - & 1,400 \\
\hline Jeep Trail well & Drakos and Hodgins, 2013 & 03/16/2012 & - & - & - & - & - & - & 1,460 \\
\hline NC-GWE-PV-04 & USGS (NWIS) & $06 / 27 / 2012$ & - & - & - & - & - & - & - \\
\hline NC-GWE-PV-04 & USGS (NWIS) & $10 / 15 / 2012$ & $<0.025$ & - & 0.19 & 4.54 & 0.17 & 0.67 & 571 \\
\hline Stump Spring well & Drakos and Hodgins, 2013 & $02 / 28 / 2012$ & - & - & - & - & - & - & - \\
\hline Stump Spring well & USGS (NWIS) & $06 / 22 / 2009$ & 0.133 & - & 1.29 & 2.74 & 0.71 & 0.71 & 1,180 \\
\hline Stump Spring well & USGS (NWIS) & $05 / 20 / 2010$ & - & - & - & - & - & - & 1,220 \\
\hline Black Mountain precipitation & USGS (NWIS) & $03 / 11 / 2013$ & - & - & - & - & - & - & - \\
\hline Kingston Range precipitation & USGS (NWIS) & $01 / 16 / 2013$ & - & - & - & - & - & - & - \\
\hline Mt Charleston precipitation & USGS (NWIS) & $05 / 23 / 2013$ & - & - & - & - & - & - & - \\
\hline Nopah Range precipitation & USGS (NWIS) & 03/19/2013 & - & - & - & - & - & - & - \\
\hline Borax Spring & Larsen and others, 2001 & 01/03/1999 & - & - & - & - & - & - & - \\
\hline Borax Spring & Source Group, Inc., 2011 & $04 / 27 / 2011$ & - & - & - & - & - & - & 44 \\
\hline Borax Spring & Source Group, Inc., 2011 & $09 / 21 / 2011$ & - & - & - & - & - & - & - \\
\hline Chappo Spring & Paces and others, 2002 & 03/12/1993 & - & - & - & - & - & - & - \\
\hline Chappo Spring & Source Group, Inc., 2011 & 05/01/2011 & - & - & - & - & - & - & 917 \\
\hline Chappo Spring & Larsen and others, 2001 & 01/05/1999 & - & - & - & - & - & - & - \\
\hline
\end{tabular}


[All significant figures reflective of what was reported by sources. Data from the U.S. Geological Survey (USGS) from the USGS National Water Information System (NWIS) database. All analyses are assumed to be reported filtered values. Abbreviations: BLS, below land surface; CA, California; E, estimated value; $\mathrm{HCO}_{3}$, bicarbonate; IC, inductively coupled; ICP, inductively coupled plasma; ICP-MS, inductively coupled plasma-mass spectrometry; ID, identification; M, detected but not quantified; mg/L, milligram per liter; mm/dd/yyyy, month/day/year; NAD83, North American Datum of 1983; NA, not applicable; ND, not detected; pMC, percent modern carbon; R, radiochemical non-detect; TU, tritium unit; UTM, Universal Transverse Mercator; $\mu \mathrm{g} / \mathrm{L}$, microgram per liter; $\mu \mathrm{S} / \mathrm{cm}$, microsiemens pe centimeter; ${ }^{\circ} \mathrm{C}$, degrees Celsius; \%o, per mil; $\delta$, delta; <, less than; - , no data available]

\begin{tabular}{|c|c|c|c|c|c|c|c|c|c|}
\hline Site name & $\begin{array}{l}\text { Source } \\
\text { of data }\end{array}$ & $\begin{array}{c}\text { Sample } \\
\text { collection date } \\
\text { (mm/dd/yyyy) }\end{array}$ & $\begin{array}{l}\text { Lead } \\
(\mu \mathrm{g} / \mathrm{L})\end{array}$ & $\begin{array}{l}\text { Lithium } \\
\text { ( } \mu \mathrm{g} / \mathrm{L})\end{array}$ & $\begin{array}{c}\text { Manganese } \\
(\mu \mathrm{g} / \mathrm{L})\end{array}$ & $\begin{array}{c}\text { Molybdenum } \\
(\mu \mathrm{g} / \mathrm{L})\end{array}$ & $\begin{array}{c}\text { Nickel } \\
(\mu \mathrm{g} / \mathrm{L})\end{array}$ & $\begin{array}{c}\text { Selenium } \\
(\mu \mathrm{g} / \mathrm{L})\end{array}$ & $\begin{array}{c}\text { Strontium } \\
(\mu \mathrm{g} / \mathrm{L})\end{array}$ \\
\hline Cynthia's well & Zdon and Associates, 2014 & $04 / 25 / 2013$ & $<5.0$ & - & $<500$ & 13 & $<5.0$ & $<10$ & 690 \\
\hline Cynthia's well & Source Group, Inc., 2011 & $05 / 11 / 2011$ & - & - & - & - & - & - & 928 \\
\hline Cynthia's well & Zdon and Associates, 2014 & $01 / 16 / 2011$ & - & - & - & - & - & - & - \\
\hline Shoshone Spring & Larsen and others, 2001 & $01 / 16 / 1962$ & - & - & - & - & - & - & - \\
\hline Shoshone Spring & Larsen and others, 2001 & $02 / 27 / 1976$ & - & - & - & - & - & - & - \\
\hline Shoshone Spring & Larsen and others, 2001 & 01/06/1997 & - & - & - & - & - & - & - \\
\hline Shoshone Spring & Source Group, Inc., 2011 & $01 / 23 / 2011$ & - & - & - & - & - & - & - \\
\hline Shoshone Spring & Source Group, Inc., 2011 & $04 / 27 / 2011$ & - & - & - & - & - & - & 1,109 \\
\hline Shoshone Spring & USGS (NWIS) & 03/10/1998 & - & - & - & - & - & - & - \\
\hline Thom Spring & Source Group, Inc., 2011 & $11 / 11 / 2010$ & - & - & - & - & - & - & - \\
\hline Thom Spring & Source Group, Inc., 2011 & $04 / 27 / 2011$ & - & - & - & - & - & - & 681 \\
\hline Wild Bath Spring & USGS (NWIS) & 06/10/1998 & - & - & - & - & - & - & - \\
\hline Wild Bath Spring & Source Group, Inc., 2011 & $04 / 27 / 2011$ & - & - & - & - & - & - & 491 \\
\hline Wild Bath Spring & Source Group, Inc., 2011 & $09 / 21 / 2011$ & - & - & - & - & - & - & - \\
\hline Willow Spring & Hershey, 1989 & $06 / 26 / 1985$ & 5 & - & - & - & - & - & 390 \\
\hline Horse Springs & Drakos and Hodgins, 2013 & $03 / 05 / 2012$ & - & - & - & - & - & - & 170 \\
\hline Horse Springs & Paces and others, 2002 & $06 / 23 / 1993$ & - & - & - & - & - & - & - \\
\hline Lost Cabin Spring & Hershey, 1989 & $06 / 17 / 1987$ & - & - & - & - & - & - & - \\
\hline Lost Cabin Spring & USGS (NWIS) & $07 / 21 / 2009$ & - & - & - & - & - & - & - \\
\hline Lost Cabin Spring & USGS (NWIS) & $12 / 28 / 2009$ & E0.015 & 19.4 & 0.96 & 1.41 & 0.87 & 1.6 & 4,730 \\
\hline Lost Cabin Spring & USGS (NWIS) & $07 / 23 / 2010$ & - & - & 2.37 & - & - & - & - \\
\hline Peak Spring & Hershey, 1989 & $06 / 23 / 1987$ & - & - & - & - & - & - & 460 \\
\hline Peak Spring & USGS (NWIS) & $09 / 03 / 2008$ & $<0.080$ & - & $<0.20$ & 0.664 & 0.21 & 0.44 & 93 \\
\hline Peak Spring & USGS (NWIS) & $07 / 27 / 2009$ & - & - & - & - & - & - & - \\
\hline Peak Spring & USGS (NWIS) & $08 / 10 / 2010$ & - & - & $<0.20$ & - & - & - & - \\
\hline Rainbow Spring & Hershey, 1989 & $09 / 19 / 1982$ & - & - & - & - & - & - & 130 \\
\hline Rainbow Spring & Paces and others, 2002 & $06 / 23 / 1993$ & - & - & - & - & - & - & - \\
\hline Borehole Spring & Source Group, Inc., 2011 & $05 / 02 / 2011$ & - & - & - & - & - & - & 93 \\
\hline Borehole Spring & Source Group, Inc., 2011 & $09 / 21 / 2011$ & - & - & - & - & - & - & - \\
\hline
\end{tabular}


Table 9. Water chemistry of selected samples from the Lower Amargosa Valley and extra-basin contributing areas, California and Nevada.-Continued

[All significant figures reflective of what was reported by sources. Data from the U.S. Geological Survey (USGS) from the USGS National Water Information System (NWIS) database. All analyses are assumed to be reported filtered values. Abbreviations: BLS, below land surface; CA, California; E, estimated value; $\mathrm{HCO}_{3}$, bicarbonate; IC, inductively coupled; ICP, inductively coupled plasma;

ICP-MS, inductively coupled plasma-mass spectrometry; ID, identification; M, detected but not quantified; mg/L, milligram per liter; mm/dd/yyyy, month/day/year; NAD83, North American Datum of 1983; NA, not applicable; ND, not detected; pMC, percent modern carbon; R, radiochemical non-detect; TU, tritium unit; UTM, Universal Transverse Mercator; $\mu \mathrm{g} / \mathrm{L}$, microgram per liter; $\mu \mathrm{S} / \mathrm{cm}$, microsiemens per centimeter; ${ }^{\circ} \mathrm{C}$, degrees Celsius; \%o, per mil; $\delta$, delta; $<$, less than; - , no data available]

\begin{tabular}{|c|c|c|c|c|c|c|c|c|c|}
\hline Site name & $\begin{array}{l}\text { Source } \\
\text { of data }\end{array}$ & $\begin{array}{c}\text { Sample } \\
\text { collection date } \\
\text { (mm/dd/yyyy) }\end{array}$ & $\begin{array}{l}\text { Lead } \\
(\mu \mathrm{g} / \mathrm{L})\end{array}$ & $\begin{array}{c}\text { Lithium } \\
\text { ( } \mu \mathrm{g} / \mathrm{L})\end{array}$ & $\begin{array}{c}\text { Manganese } \\
(\mu \mathrm{g} / \mathrm{L})\end{array}$ & $\begin{array}{c}\text { Molybdenum } \\
(\mu \mathrm{g} / \mathrm{L})\end{array}$ & $\begin{array}{c}\text { Nickel } \\
\text { ( } \mu \mathrm{g} / \mathrm{L})\end{array}$ & $\begin{array}{l}\text { Selenium } \\
\text { ( } \mu \mathrm{g} / \mathrm{L})\end{array}$ & $\begin{array}{c}\text { Strontium } \\
(\mu \mathrm{g} / \mathrm{L})\end{array}$ \\
\hline Tecopa Hot Springs & Hershey and others, 2009 & 05/04/1992 & - & 220 & - & - & - & - & 110 \\
\hline Tecopa Hot Springs & Larsen and others, 2001 & 01/06/1997 & - & - & - & - & - & - & - \\
\hline Tecopa Hot Springs & Source Group, Inc., 2011 & $04 / 27 / 2011$ & - & - & - & - & - & - & 89 \\
\hline Tecopa Hot Springs & Source Group, Inc., 2011 & 09/21/2011 & - & - & - & - & - & - & - \\
\hline Tecopa Hot Springs & Steinkampf and Werrell, 2001 & 06/30/1985 & - & - & - & - & - & - & - \\
\hline Site name & $\begin{array}{l}\text { Source } \\
\text { of data }\end{array}$ & $\begin{array}{c}\text { Sample } \\
\text { collection date } \\
\text { (mm/dd/yyyy) }\end{array}$ & $\begin{array}{c}\text { Uranium } \\
\text { ( } \mu \mathrm{g} / \mathrm{L})\end{array}$ & $\begin{array}{l}\text { Zinc } \\
(\mu \mathrm{g} / \mathrm{L})\end{array}$ & \multicolumn{2}{|c|}{$\begin{array}{l}\text { Nitrate + nitrite } \\
\text { as nitrate } \\
(\mathrm{mg} / \mathrm{L})\end{array}$} & \multicolumn{3}{|c|}{$\begin{array}{l}\text { Methods used for analyzing } \\
\text { majors ions and trace elements, } \\
\text { if known }\end{array}$} \\
\hline Amargosa Canyon Spring 1 & Source Group, Inc., 2011 & $04 / 25 / 2011$ & 2.36 & - & - & & \multicolumn{3}{|c|}{ IC and ICP } \\
\hline Amargosa Canyon Spring 1 & Source Group, Inc., 2011 & $12 / 22 / 2011$ & - & - & 一 & & \multicolumn{3}{|c|}{ IC and ICP } \\
\hline Amargosa Canyon Spring 4 & Source Group, Inc., 2011 & $04 / 25 / 2011$ & 8.35 & - & - & & \multicolumn{3}{|c|}{ IC and ICP } \\
\hline Amargosa Canyon Spring 4 & Source Group, Inc., 2011 & $12 / 22 / 2011$ & - & - & - & & \multicolumn{3}{|c|}{ IC and ICP } \\
\hline Willow Spring & Larsen and others, 2001 & 01/04/1999 & - & - & 0.1 & & \multicolumn{3}{|c|}{ IC and spectrophotometry } \\
\hline Willow Spring & Paces and others, 2002 & 03/11/1993 & 0.685 & - & - & & \multicolumn{3}{|c|}{ NA } \\
\hline Willow Spring & Source Group, Inc., 2011 & $04 / 26 / 2011$ & 6.39 & - & - & & \multicolumn{3}{|c|}{ IC and ICP } \\
\hline Willow Spring & Source Group, Inc., 2011 & 09/23/2011 & - & - & - & & \multicolumn{3}{|c|}{ IC and ICP } \\
\hline Amargosa River (AR3314; Seepage Run) & USGS (NWIS) & 03/27/2014 & 16.2 & $<20.0$ & - & & \multicolumn{3}{|c|}{ IC, ICP, and ICP-MS } \\
\hline Amargosa River 2 & Source Group, Inc., 2011 & $11 / 17 / 2010$ & - & - & - & & \multicolumn{3}{|c|}{ IC and ICP } \\
\hline Amargosa River 2 & Source Group, Inc., 2011 & 05/02/2011 & 18.09 & - & - & & \multicolumn{3}{|c|}{ IC and ICP } \\
\hline Amargosa River at Tecopa, CA & USGS (NWIS) & $03 / 15 / 2005$ & - & 4.8 & 0.8 & & \multicolumn{3}{|c|}{ IC, ICP, and ICP-MS } \\
\hline Amargosa River at Tecopa, CA & USGS (NWIS) & $03 / 27 / 2014$ & 13.6 & $<20.0$ & - & & \multicolumn{3}{|c|}{ IC, ICP, and ICP-MS } \\
\hline Amargosa River in Upper Canyon near Tecopa, CA & USGS (NWIS) & 03/15/2005 & - & 2.2 & 0.37 & & \multicolumn{3}{|c|}{ IC, ICP, and ICP-MS } \\
\hline Crystal Pool & Dudley and Larsen, 1976 & $11 / 1966$ & - & - & $<0.1$ & & \multicolumn{3}{|c|}{ No information given } \\
\hline Crystal Pool & Gomez and others, 2013 & - & 3.21 & - & 0.34 & & \multicolumn{3}{|c|}{ No information given } \\
\hline Crystal Pool & Hershey and others, 2010 & 03/17/1992 & - & - & $0.0 \mathrm{~s}$ & & \multicolumn{3}{|c|}{ IC and ICP } \\
\hline Crystal Pool & USGS (NWIS) & 05/07/1997 & 3 & $<1.0$ & 0.08 & & \multicolumn{3}{|c|}{ IC, ICP, and ICP-MS } \\
\hline Devils Hole (AM-4) & Thomas and others, 1996 & - & - & - & - & & \multicolumn{3}{|c|}{ NA } \\
\hline Devils Hole (AM-4) & Gomez and others, 2013 & - & 3.33 & - & 0.72 & & \multicolumn{3}{|c|}{ No information given } \\
\hline
\end{tabular}


[All significant figures reflective of what was reported by sources. Data from the U.S. Geological Survey (USGS) from the USGS National Water Information System (NWIS) database. All analyses are assumed to be reported filtered values. Abbreviations: BLS, below land surface; CA, California; E, estimated value; $\mathrm{HCO}_{3}$, bicarbonate; IC, inductively coupled; ICP, inductively coupled plasma; ICP-MS, inductively coupled plasma-mass spectrometry; ID, identification; M, detected but not quantified; mg/L, milligram per liter; mm/dd/yyyy, month/day/year; NAD83, North American Datum of 1983; NA, not applicable; ND, not detected; pMC, percent modern carbon; R, radiochemical non-detect; TU, tritium unit; UTM, Universal Transverse Mercator; $\mu \mathrm{g} / \mathrm{L}$, microgram per liter; $\mu \mathrm{S} / \mathrm{cm}$, microsiemens pe centimeter; ${ }^{\circ} \mathrm{C}$, degrees Celsius; \%o, per mil; $\delta$, delta; <, less than; - , no data available]

\begin{tabular}{|c|c|c|c|c|c|c|}
\hline Site name & $\begin{array}{l}\text { Source } \\
\text { of data }\end{array}$ & $\begin{array}{c}\text { Sample } \\
\text { collection date } \\
\text { (mm/dd/yyyy) }\end{array}$ & $\begin{array}{c}\text { Uranium } \\
\text { ( } \mu \mathrm{g} / \mathrm{L})\end{array}$ & $\begin{array}{c}\text { Zinc } \\
(\mu \mathrm{g} / \mathrm{L})\end{array}$ & $\begin{array}{l}\text { Nitrate }+ \text { nitrite } \\
\text { as nitrate } \\
(\mathrm{mg} / \mathrm{L})\end{array}$ & $\begin{array}{c}\text { Methods used for analyzing } \\
\text { majors ions and trace elements, } \\
\text { if known }\end{array}$ \\
\hline Devils Hole (AM-4) & Hershey and others, 2009 & $07 / 09 / 1992$ & - & - & 0.18 & IC and ICP \\
\hline Devils Hole (AM-4) & USGS (NWIS) & 06/03/1984 & - & M & 0.147 & IC, ICP, and ICP-MS \\
\hline Devils Hole (AM-4) & USGS (NWIS) & 06/03/1984 & - & 20 & 0.151 & IC, ICP, and ICP-MS \\
\hline Devils Hole (AM-4) & USGS (NWIS) & 03/09/1985 & - & M & 0.15 & IC, ICP, and ICP-MS \\
\hline Devils Hole (AM-4) & USGS (NWIS) & 03/09/1985 & - & M & 0.14 & IC, ICP, and ICP-MS \\
\hline Devils Hole (AM-4) & USGS (NWIS) & 03/10/1985 & - & M & 0.15 & IC, ICP, and ICP-MS \\
\hline Devils Hole (AM-4) & USGS (NWIS) & 05/05/1986 & - & - & 0.155 & IC, ICP, and ICP-MS \\
\hline Devils Hole (AM-4) & USGS (NWIS) & 05/05/1986 & - & - & 0.145 & IC, ICP, and ICP-MS \\
\hline Devils Hole (AM-4) & USGS (NWIS) & $11 / 16 / 1986$ & - & - & 0.164 & IC, ICP, and ICP-MS \\
\hline Devils Hole (AM-4) & USGS (NWIS) & $11 / 16 / 1986$ & - & - & 0.164 & IC, ICP, and ICP-MS \\
\hline Devils Hole (AM-4) & USGS (NWIS) & $06 / 22 / 1987$ & - & - & 0.138 & IC, ICP, and ICP-MS \\
\hline Devils Hole (AM-4) & USGS (NWIS) & $06 / 22 / 1987$ & - & - & 0.151 & IC, ICP, and ICP-MS \\
\hline Devils Hole (AM-4) & USGS (NWIS) & 03/16/1988 & - & - & 0.108 & IC, ICP, and ICP-MS \\
\hline Devils Hole (AM-4) & USGS (NWIS) & 03/16/1988 & - & - & 0.102 & IC, ICP, and ICP-MS \\
\hline Devils Hole (AM-4) & USGS (NWIS) & $12 / 07 / 1988$ & - & - & 0.138 & IC, ICP, and ICP-MS \\
\hline Devils Hole (AM-4) & USGS (NWIS) & $12 / 07 / 1988$ & - & - & 0.138 & IC, ICP, and ICP-MS \\
\hline Devils Hole (AM-4) & USGS (NWIS) & 06/21/1989 & - & - & 0.146 & IC, ICP, and ICP-MS \\
\hline Devils Hole (AM-4) & USGS (NWIS) & 06/21/1989 & - & - & 0.151 & IC, ICP, and ICP-MS \\
\hline Devils Hole (AM-4) & USGS (NWIS) & 06/25/1990 & - & - & 0.126 & IC, ICP, and ICP-MS \\
\hline Devils Hole (AM-4) & USGS (NWIS) & 06/25/1990 & - & - & 0.132 & IC, ICP, and ICP-MS \\
\hline Devils Hole (AM-4) & USGS (NWIS) & 08/22/1990 & - & $<3.0$ & 0.1 & IC, ICP, and ICP-MS \\
\hline Devils Hole (AM-4) & USGS (NWIS) & 08/15/1991 & - & - & 0.406 & IC, ICP, and ICP-MS \\
\hline Devils Hole (AM-4) & USGS (NWIS) & 08/27/1991 & 4 & 3 & 0.14 & IC, ICP, and ICP-MS \\
\hline Devils Hole (AM-4) & USGS (NWIS) & 08/19/1992 & 4 & 4 & 0.16 & IC, ICP, and ICP-MS \\
\hline Devils Hole (AM-4) & USGS (NWIS) & 08/18/1999 & 3.02 & $<1.0$ & 0.141 & IC, ICP, and ICP-MS \\
\hline Devils Hole (AM-4) & USGS (NWIS) & 08/18/1999 & 3.05 & 1.6 & 0.114 & IC, ICP, and ICP-MS \\
\hline Devils Hole (AM-4) & USGS (NWIS) & 08/18/1999 & - & - & - & IC, ICP, and ICP-MS \\
\hline Devils Hole (AM-4) & USGS (NWIS) & 09/23/1999 & - & - & - & IC, ICP, and ICP-MS \\
\hline
\end{tabular}


Table 9. Water chemistry of selected samples from the Lower Amargosa Valley and extra-basin contributing areas, California and Nevada.-Continued

[All significant figures reflective of what was reported by sources. Data from the U.S. Geological Survey (USGS) from the USGS National Water Information System (NWIS) database. All analyses are assumed to be reported filtered values. Abbreviations: BLS, below land surface; CA, California; E, estimated value; $\mathrm{HCO}_{3}$, bicarbonate; IC, inductively coupled; ICP, inductively coupled plasma;

ICP-MS, inductively coupled plasma-mass spectrometry; ID, identification; M, detected but not quantified; mg/L, milligram per liter; mm/dd/yyyy, month/day/year; NAD83, North American Datum of 1983; $\mathrm{NA}$, not applicable; ND, not detected; pMC, percent modern carbon; R, radiochemical non-detect; TU, tritium unit; UTM, Universal Transverse Mercator; $\mu \mathrm{g} / \mathrm{L}$, microgram per liter; $\mu \mathrm{S} / \mathrm{cm}$, microsiemens per centimeter; ${ }^{\circ} \mathrm{C}$, degrees Celsius; \%o, per mil; $\delta$, delta; $<$, less than; - , no data available]

\begin{tabular}{|c|c|c|c|c|c|c|}
\hline Site name & $\begin{array}{l}\text { Source } \\
\text { of data }\end{array}$ & $\begin{array}{c}\text { Sample } \\
\text { collection date } \\
\text { (mm/dd/yyyy) }\end{array}$ & $\begin{array}{c}\text { Uranium } \\
\text { ( } \mu \mathrm{g} / \mathrm{L} \text { ) }\end{array}$ & $\begin{array}{c}\text { Zinc } \\
(\mu \mathrm{g} / \mathrm{L})\end{array}$ & $\begin{array}{l}\text { Nitrate }+ \text { nitrite } \\
\text { as nitrate } \\
(\mathrm{mg} / \mathrm{L})\end{array}$ & $\begin{array}{c}\text { Methods used for analyzing } \\
\text { majors ions and trace elements, } \\
\text { if known }\end{array}$ \\
\hline Devils Hole (AM-4) & USGS (NWIS) & $09 / 10 / 2003$ & 3.18 & 1.5 & 0.138 & IC, ICP, and ICP-MS \\
\hline Devils Hole (AM-4) & USGS (NWIS) & $09 / 10 / 2003$ & - & - & - & IC, ICP, and ICP-MS \\
\hline Devils Hole (AM-4) & USGS (NWIS) & $09 / 27 / 2005$ & 3.16 & 0.9 & 0.134 & IC, ICP, and ICP-MS \\
\hline Devils Hole (AM-4) & USGS (NWIS) & $09 / 27 / 2005$ & - & - & - & IC, ICP, and ICP-MS \\
\hline Fairbanks Spring & Dudley and Larsen, 1976 & $11 / 1966$ & - & - & $<0.1$ & No information given \\
\hline Fairbanks Spring & Gomez and others, 2013 & - & 2.65 & - & - & No information given \\
\hline Fairbanks Spring & Hershey and others, 2010 & 03/17/1992 & - & - & 0.04 & IC and ICP \\
\hline Fairbanks Spring & Thomas and others, 1996 & - & - & - & - & NA \\
\hline Fairbanks Spring & USGS (NWIS) & 05/06/1997 & 3 & $<1.00$ & $<0.05$ & IC, ICP, and ICP-MS \\
\hline Five Springs well (AM-2) & Gomez and others, 2013 & - & 3.05 & - & 0.22 & No information given \\
\hline Five Springs well (AM-2) & Source Group, Inc., 2011 & $05 / 01 / 2011$ & - & - & - & IC and ICP \\
\hline Five Springs well (AM-2) & USGS (NWIS) & 08/24/1990 & - & 7 & $<0.100$ & IC, ICP, and ICP-MS \\
\hline Five Springs well (AM-2) & USGS (NWIS) & 04/28/1992 & 2.00 & 8 & $<0.050$ & IC, ICP, and ICP-MS \\
\hline Five Springs well (AM-2) & USGS (NWIS) & $10 / 18 / 1994$ & - & - & - & IC, ICP, and ICP-MS \\
\hline Five Springs well (AM-2) & USGS (NWIS) & 09/22/1996 & - & - & - & IC, ICP, and ICP-MS \\
\hline Hog Farm well & Zdon and Associates, 2014 & $04 / 25 / 2013$ & - & $<10$ & ND & IC and ICP \\
\hline Point of Rocks Spring & Gomez and others, 2013 & - & 3.10 & - & - & No information given \\
\hline Point of Rocks Spring & Hershey and others, 2010 & - & - & - & - & IC and ICP \\
\hline Tule Spring & Hershey, 1989 & $06 / 30 / 1985$ & - & - & - & Spectrophotometry \\
\hline Tule Spring & USGS (NWIS) & $01 / 16 / 2013$ & 1.33 & $<1.4$ & - & IC, ICP, and ICP-MS \\
\hline Resting Spring & Paces and others, 2002 & 03/11/1993 & 2.39 & - & - & NA \\
\hline Resting Spring & Source Group, Inc., 2011 & $01 / 23 / 2011$ & - & - & - & IC and ICP \\
\hline Resting Spring & Source Group, Inc., 2011 & $05 / 25 / 2011$ & 2.4 & - & - & IC and ICP \\
\hline Twelvemile Spring & Zdon and Associates, 2014 & $04 / 25 / 2013$ & - & 55 & 0.19 & IC and ICP \\
\hline Twelvemile Spring & Source Group, Inc., 2011 & $11 / 14 / 2010$ & - & - & - & IC and ICP \\
\hline Twelvemile Spring & USGS (NWIS) & $03 / 21 / 2013$ & 1.04 & $<1.4$ & - & IC, ICP, and ICP-MS \\
\hline Salsberry Spring & Paces and others, 2002 & 06/17/1998 & 0.010 & - & - & NA \\
\hline Salsberry Spring & USGS (NWIS) & $03 / 11 / 2013$ & 1.30 & 9.02 & - & IC, ICP, and ICP-MS \\
\hline
\end{tabular}


[All significant figures reflective of what was reported by sources. Data from the U.S. Geological Survey (USGS) from the USGS National Water Information System (NWIS) database. All analyses are assumed to be reported filtered values. Abbreviations: BLS, below land surface; CA, California; E, estimated value; $\mathrm{HCO}_{3}$, bicarbonate; IC, inductively coupled; ICP, inductively coupled plasma; ICP-MS, inductively coupled plasma-mass spectrometry; ID, identification; M, detected but not quantified; mg/L, milligram per liter; mm/dd/yyyy, month/day/year; NAD83, North American Datum of 1983; NA, not applicable; ND, not detected; pMC, percent modern carbon; R, radiochemical non-detect; TU, tritium unit; UTM, Universal Transverse Mercator; $\mu \mathrm{g} / \mathrm{L}$, microgram per liter; $\mu \mathrm{S} / \mathrm{cm}$, microsiemens pe centimeter; ${ }^{\circ} \mathrm{C}$, degrees Celsius; \%o, per mil; $\delta$, delta; <, less than; - , no data available]

\begin{tabular}{|c|c|c|c|c|c|c|}
\hline Site name & $\begin{array}{l}\text { Source } \\
\text { of data }\end{array}$ & $\begin{array}{c}\text { Sample } \\
\text { collection date } \\
\text { (mm/dd/yyyy) }\end{array}$ & $\begin{array}{c}\text { Uranium } \\
\text { ( } \mu \mathrm{g} / \mathrm{L})\end{array}$ & $\begin{array}{c}\text { Zinc } \\
(\mu \mathrm{g} / \mathrm{L})\end{array}$ & $\begin{array}{c}\text { Nitrate + nitrite } \\
\text { as nitrate } \\
\text { (mg/L) }\end{array}$ & $\begin{array}{c}\text { Methods used for analyzing } \\
\text { majors ions and trace elements, } \\
\text { if known }\end{array}$ \\
\hline Crystal Spring & Drakos and Hodgins, 2013 & $03 / 14 / 2012$ & - & - & ND & ICP and ICP-MS \\
\hline Crystal Spring & Paces and others, 2002 & $02 / 05 / 1990$ & 3.77 & - & - & NA \\
\hline Crystal Spring & Zdon and Associates, 2014 & $04 / 26 / 2011$ & - & - & - & IC and ICP \\
\hline Crystal Spring & Zdon and Associates, 2014 & $04 / 27 / 2011$ & 1.3 & - & - & IC and ICP \\
\hline Crystal Spring & USGS (NWIS) & 08/10/1994 & - & - & - & IC, ICP, and ICP-MS \\
\hline Crystal Spring & USGS (NWIS) & 08/10/1994 & - & - & - & IC, ICP, and ICP-MS \\
\hline Crystal Spring & USGS (NWIS) & 09/23/1996 & - & - & - & IC, ICP, and ICP-MS \\
\hline Crystal Spring & USGS (NWIS) & $07 / 27 / 1998$ & - & 12.0 & - & IC, ICP, and ICP-MS \\
\hline Nevada National Security Site well & Gomez and others, 2013 & - & 3.06 & - & - & No information given \\
\hline 162 S20 E 5323 ABAD1 U19 & USGS (NWIS) & $11 / 07 / 2013$ & 1.44 & 2.2 & 0.411 & IC, ICP, and ICP-MS \\
\hline Hidden Hills Ranch well & Hershey, 1989 & 07/30/1987 & - & - & 0.53 & Spectrophotometry \\
\hline Jeep Trail well & Drakos and Hodgins, 2013 & $03 / 16 / 2012$ & - & - & 0.24 & ICP and ICP-MS \\
\hline NC-GWE-PV-04 & USGS (NWIS) & $06 / 27 / 2012$ & - & - & 0.435 & IC, ICP, and ICP-MS \\
\hline NC-GWE-PV-04 & USGS (NWIS) & $10 / 15 / 2012$ & 2.3 & 3 & 0.329 & IC, ICP, and ICP-MS \\
\hline Stump Spring well & Drakos and Hodgins, 2013 & $02 / 28 / 2012$ & - & - & 0.17 & ICP and ICP-MS \\
\hline Stump Spring well & USGS (NWIS) & $06 / 22 / 2009$ & 1.25 & 3.3 & 0.18 & IC, ICP, and ICP-MS \\
\hline Stump Spring well & USGS (NWIS) & $05 / 20 / 2010$ & 1.14 & - & - & IC, ICP, and ICP-MS \\
\hline Black Mountain precipitation & USGS (NWIS) & $03 / 11 / 2013$ & - & - & - & IC, ICP, and ICP-MS \\
\hline Kingston Range precipitation & USGS (NWIS) & $01 / 16 / 2013$ & - & - & - & IC, ICP, and ICP-MS \\
\hline Mt Charleston precipitation & USGS (NWIS) & $05 / 23 / 2013$ & - & - & - & NA \\
\hline Nopah Range precipitation & USGS (NWIS) & $03 / 19 / 2013$ & - & - & - & IC, ICP, and ICP-MS \\
\hline Borax Spring & Larsen and others, 2001 & 01/03/1999 & - & - & ND & IC and spectrophotometry \\
\hline Borax Spring & Source Group, Inc., 2011 & $04 / 27 / 2011$ & 1.21 & - & - & IC and ICP \\
\hline Borax Spring & Source Group, Inc., 2011 & $09 / 21 / 2011$ & - & - & - & IC and ICP \\
\hline Chappo Spring & Paces and others, 2002 & 03/12/1993 & 1.82 & - & - & NA \\
\hline Chappo Spring & Source Group, Inc., 2011 & $05 / 01 / 2011$ & 1.8 & - & - & IC and ICP \\
\hline Chappo Spring & Larsen and others, 2001 & 01/05/1999 & - & - & 0.2 & IC and spectrophotometry \\
\hline Cynthia's well & Zdon and Associates, 2014 & $04 / 25 / 2013$ & - & $<10$ & - & IC and ICP \\
\hline
\end{tabular}


Table 9. Water chemistry of selected samples from the Lower Amargosa Valley and extra-basin contributing areas, California and Nevada.-Continued

[All significant figures reflective of what was reported by sources. Data from the U.S. Geological Survey (USGS) from the USGS National Water Information System (NWIS) database. All analyses are assumed to be reported filtered values. Abbreviations: BLS, below land surface; CA, California; E, estimated value; $\mathrm{HCO}_{3}$, bicarbonate; IC, inductively coupled; ICP, inductively coupled plasma;

ICP-MS, inductively coupled plasma-mass spectrometry; ID, identification; M, detected but not quantified; mg/L, milligram per liter; mm/dd/yyyy, month/day/year; NAD83, North American Datum of 1983; $\mathrm{NA}$, not applicable; ND, not detected; pMC, percent modern carbon; R, radiochemical non-detect; TU, tritium unit; UTM, Universal Transverse Mercator; $\mu \mathrm{g} / \mathrm{L}$, microgram per liter; $\mu \mathrm{S} / \mathrm{cm}$, microsiemens per centimeter; ${ }^{\circ} \mathrm{C}$, degrees Celsius; \%o, per mil; $\delta$, delta; $<$, less than; - , no data available]

\begin{tabular}{|c|c|c|c|c|c|c|}
\hline Site name & $\begin{array}{l}\text { Source } \\
\text { of data }\end{array}$ & $\begin{array}{c}\text { Sample } \\
\text { collection date } \\
\text { (mm/dd/yyyy) }\end{array}$ & $\begin{array}{c}\text { Uranium } \\
\text { ( } \mu \mathrm{g} / \mathrm{L})\end{array}$ & $\begin{array}{c}\text { Zinc } \\
(\mu \mathrm{g} / \mathrm{L})\end{array}$ & $\begin{array}{l}\text { Nitrate + nitrite } \\
\text { as nitrate } \\
(\mathrm{mg} / \mathrm{L})\end{array}$ & $\begin{array}{c}\text { Methods used for analyzing } \\
\text { majors ions and trace elements, } \\
\text { if known }\end{array}$ \\
\hline Cynthia's well & Source Group, Inc., 2011 & $05 / 11 / 2011$ & 5.66 & - & - & IC and ICP \\
\hline Cynthia's well & Zdon and Associates, 2014 & 01/16/2011 & - & - & - & IC and ICP \\
\hline Shoshone Spring & Larsen and others, 2001 & $01 / 16 / 1962$ & - & - & 1.1 & IC and spectrophotometry \\
\hline Shoshone Spring & Larsen and others, 2001 & 02/27/1976 & - & - & 1.8 & IC and spectrophotometry \\
\hline Shoshone Spring & Larsen and others, 2001 & 01/06/1997 & - & - & 1.4 & IC and spectrophotometry \\
\hline Shoshone Spring & Source Group, Inc., 2011 & $01 / 23 / 2011$ & - & - & - & IC and ICP \\
\hline Shoshone Spring & Source Group, Inc., 2011 & $04 / 27 / 2011$ & 3.82 & - & - & IC and ICP \\
\hline Shoshone Spring & USGS (NWIS) & 03/10/1998 & - & - & - & IC, ICP, and ICP-MS \\
\hline Thom Spring & Source Group, Inc., 2011 & $11 / 11 / 2010$ & - & - & - & IC and ICP \\
\hline Thom Spring & Source Group, Inc., 2011 & $04 / 27 / 2011$ & 4.47 & - & - & IC and ICP \\
\hline Wild Bath Spring & USGS (NWIS) & 06/10/1998 & - & - & - & - \\
\hline Wild Bath Spring & Source Group, Inc., 2011 & $04 / 27 / 2011$ & 2.88 & - & - & IC and ICP \\
\hline Wild Bath Spring & Source Group, Inc., 2011 & $09 / 21 / 2011$ & - & - & - & IC and ICP \\
\hline Willow Spring & Hershey, 1989 & $06 / 26 / 1985$ & - & - & 1.73 & Spectrophotometry \\
\hline Horse Springs & Drakos and Hodgins, 2013 & $03 / 05 / 2012$ & - & - & 0.61 & ICP and ICP-MS \\
\hline Horse Springs & Paces and others, 2002 & $06 / 23 / 1993$ & 1.44 & - & - & NA \\
\hline Lost Cabin Spring & Hershey, 1989 & 06/17/1987 & - & - & - & Spectrophotometry \\
\hline Lost Cabin Spring & USGS (NWIS) & $07 / 21 / 2009$ & - & - & - & IC, ICP, and ICP-MS \\
\hline Lost Cabin Spring & USGS (NWIS) & $12 / 28 / 2009$ & 2.15 & $<2.8$ & 1.42 & IC, ICP, and ICP-MS \\
\hline Lost Cabin Spring & USGS (NWIS) & $07 / 23 / 2010$ & - & - & - & IC, ICP, and ICP-MS \\
\hline Peak Spring & Hershey, 1989 & 06/23/1987 & - & - & - & IC and ICP \\
\hline Peak Spring & USGS (NWIS) & 09/03/2008 & 0.643 & $<1.8$ & 0.24 & IC, ICP, and ICP-MS \\
\hline Peak Spring & USGS (NWIS) & $07 / 27 / 2009$ & - & - & - & IC, ICP, and ICP-MS \\
\hline Peak Spring & USGS (NWIS) & 08/10/2010 & - & - & - & IC, ICP, and ICP-MS \\
\hline Rainbow Spring & Hershey, 1989 & 09/19/1982 & - & - & 3.19 & Spectrophotometry \\
\hline Rainbow Spring & Paces and others, 2002 & 06/23/1993 & 1.84 & - & - & NA \\
\hline Borehole Spring & Source Group, Inc., 2011 & 05/02/2011 & 6.62 & - & - & IC and ICP \\
\hline Borehole Spring & Source Group, Inc., 2011 & $09 / 21 / 2011$ & - & - & - & $\mathrm{IC}$ and ICP \\
\hline
\end{tabular}


[All significant figures reflective of what was reported by sources. Data from the U.S. Geological Survey (USGS) from the USGS National Water Information System (NWIS) database. All analyses are assumed to be reported filtered values. Abbreviations: BLS, below land surface; CA, California; E, estimated value; $\mathrm{HCO}_{3}$, bicarbonate; IC, inductively coupled; ICP, inductively coupled plasma; ICP-MS, inductively coupled plasma-mass spectrometry; ID, identification; M, detected but not quantified; mg/L, milligram per liter; mm/dd/yyyy, month/day/year; NAD83, North American Datum of 1983; NA, not applicable; ND, not detected; pMC, percent modern carbon; R, radiochemical non-detect; TU, tritium unit; UTM, Universal Transverse Mercator; $\mu \mathrm{g} / \mathrm{L}$, microgram per liter; $\mu \mathrm{S} / \mathrm{cm}$, microsiemens pe centimeter; ${ }^{\circ} \mathrm{C}$, degrees Celsius; \%o, per mil; $\delta$, delta; <, less than; - , no data available]

\begin{tabular}{|c|c|c|c|c|c|c|c|}
\hline Site name & $\begin{array}{l}\text { Source } \\
\text { of data }\end{array}$ & $\begin{array}{c}\text { Sample } \\
\text { collection date } \\
\text { (mm/dd/yyyy) }\end{array}$ & $\begin{array}{c}\text { Uranium } \\
(\mu \mathrm{g} / \mathrm{L})\end{array}$ & \multicolumn{2}{|c|}{$\begin{array}{l}\text { Nitrate + nitrite } \\
\text { as nitrate } \\
(\mathrm{mg} / \mathrm{L})\end{array}$} & \multicolumn{2}{|c|}{$\begin{array}{c}\text { Methods used for analyzing } \\
\text { majors ions and trace elements, } \\
\text { if known }\end{array}$} \\
\hline Tecopa Hot Springs & Hershey and others, 2009 & $05 / 04 / 1992$ & - & \multicolumn{2}{|c|}{0.07} & \multicolumn{2}{|c|}{ IC and ICP } \\
\hline Tecopa Hot Springs & Larsen and others, 2001 & 01/06/1997 & - & \multicolumn{2}{|c|}{0.1} & \multicolumn{2}{|c|}{ IC and spectrophotometry } \\
\hline Tecopa Hot Springs & Source Group, Inc., 2011 & $04 / 27 / 2011$ & 7.07 & \multicolumn{2}{|c|}{ - } & \multicolumn{2}{|c|}{ IC and ICP } \\
\hline Tecopa Hot Springs & Source Group, Inc., 2011 & $09 / 21 / 2011$ & - & \multicolumn{2}{|c|}{-} & \multicolumn{2}{|c|}{ IC and ICP } \\
\hline Tecopa Hot Springs & Steinkampf and Werrell, 2001 & $06 / 30 / 1985$ & - & \multicolumn{2}{|c|}{0.6} & \multicolumn{2}{|c|}{ IC, ICP, and ICP-MS } \\
\hline Site name & $\begin{array}{l}\text { Source } \\
\text { of data }\end{array}$ & $\begin{array}{c}\text { Sample } \\
\text { collection date } \\
\text { (mm/dd/yyyy) }\end{array}$ & $\begin{array}{l}\text { Tritium, } \\
\text { in TU }\end{array}$ & $\begin{array}{l}\delta^{2} H \\
(\%)\end{array}$ & $\begin{array}{l}\delta^{18} 0 \\
(\%)\end{array}$ & $\begin{array}{c}\text { C14 } \\
\text { (pMC) }\end{array}$ & $\begin{array}{l}\delta^{13} \mathbf{C} \\
(\%)\end{array}$ \\
\hline Amargosa Canyon Spring 1 & Source Group, Inc., 2011 & $04 / 25 / 2011$ & 1.10 & -94.0 & -12.9 & - & - \\
\hline Amargosa Canyon Spring 1 & Source Group, Inc., 2011 & $12 / 22 / 2011$ & - & - & - & - & - \\
\hline Amargosa Canyon Spring 4 & Source Group, Inc., 2011 & $04 / 25 / 2011$ & 0.70 & -95.0 & -13.1 & - & - \\
\hline Amargosa Canyon Spring 4 & Source Group, Inc., 2011 & $12 / 22 / 2011$ & - & - & - & - & - \\
\hline Willow Spring & Larsen and others, 2001 & 01/04/1999 & - & -95 & -12.7 & - & - \\
\hline Willow Spring & Paces and others, 2002 & 03/11/1993 & - & - & - & - & - \\
\hline Willow Spring & Source Group, Inc., 2011 & $04 / 26 / 2011$ & $<0.8$ & -95.0 & -12.8 & - & - \\
\hline Willow Spring & Source Group, Inc., 2011 & $09 / 23 / 2011$ & - & - & - & - & - \\
\hline Amargosa River (AR3314; Seepage Run) & USGS (NWIS) & $03 / 27 / 2014$ & - & -81.47 & -9.21 & - & - \\
\hline Amargosa River 2 & Source Group, Inc., 2011 & $11 / 17 / 2010$ & - & - & - & - & - \\
\hline Amargosa River 2 & Source Group, Inc., 2011 & $05 / 02 / 2011$ & 0.70 & -89.0 & -11.3 & - & - \\
\hline Amargosa River at Tecopa, CA & USGS (NWIS) & $03 / 15 / 2005$ & 2.82 & -84.7 & -10.17 & - & - \\
\hline Amargosa River at Tecopa, CA & USGS (NWIS) & $03 / 27 / 2014$ & - & -81.12 & -9.1 & - & - \\
\hline Amargosa River in Upper Canyon near Tecopa, CA & USGS (NWIS) & 03/15/2005 & 1.12 & -91.9 & -11.98 & - & - \\
\hline Crystal Pool & Dudley and Larsen, 1976 & $11 / 1966$ & - & - & - & - & - \\
\hline Crystal Pool & Gomez and others, 2013 & - & - & -102.5 & -13.73 & 11.00 & -4.3 \\
\hline Crystal Pool & Hershey and others, 2010 & 03/17/1992 & $<10$ & -102.0 & -13.7 & 11.2 & -5.7 \\
\hline Crystal Pool & USGS (NWIS) & 05/07/1997 & $<0.30$ & - & - & - & - \\
\hline Devils Hole (AM-4) & Thomas and others, 1996 & - & - & -103 & -13.4 & - & - \\
\hline Devils Hole (AM-4) & Gomez and others, 2013 & - & - & - & -13.60 & 3.15 & -5.9 \\
\hline
\end{tabular}


Table 9. Water chemistry of selected samples from the Lower Amargosa Valley and extra-basin contributing areas, California and Nevada.-Continued

[All significant figures reflective of what was reported by sources. Data from the U.S. Geological Survey (USGS) from the USGS National Water Information System (NWIS) database. All analyses are assumed to be reported filtered values. Abbreviations: BLS, below land surface; CA, California; E, estimated value; $\mathrm{HCO}_{3}$, bicarbonate; IC, inductively coupled; ICP, inductively coupled plasma;

ICP-MS, inductively coupled plasma-mass spectrometry; ID, identification; M, detected but not quantified; mg/L, milligram per liter; mm/dd/yyyy, month/day/year; NAD83, North American Datum of 1983; $\mathrm{NA}$, not applicable; ND, not detected; pMC, percent modern carbon; R, radiochemical non-detect; TU, tritium unit; UTM, Universal Transverse Mercator; $\mu \mathrm{g} / \mathrm{L}$, microgram per liter; $\mu \mathrm{S} / \mathrm{cm}$, microsiemens per centimeter; ${ }^{\circ} \mathrm{C}$, degrees Celsius; \%o, per mil; $\delta$, delta; $<$, less than; - , no data available]

\begin{tabular}{|c|c|c|c|c|c|c|c|}
\hline Site name & $\begin{array}{l}\text { Source } \\
\text { of data }\end{array}$ & $\begin{array}{c}\text { Sample } \\
\text { collection date } \\
\text { (mm/dd/yyyy) }\end{array}$ & $\begin{array}{c}\text { Tritium, } \\
\text { in TU }\end{array}$ & $\begin{array}{c}\delta^{2} H \\
(\%)\end{array}$ & $\begin{array}{l}\delta^{18} 0 \\
(\%)\end{array}$ & $\begin{array}{c}\text { C14 } \\
\text { (pMC) }\end{array}$ & $\begin{array}{l}\delta^{13} \mathrm{C} \\
(\%)\end{array}$ \\
\hline Devils Hole (AM-4) & Hershey and others, 2009 & $07 / 09 / 1992$ & $<10$ & -103 & -13.4 & 2.8 & -6.8 \\
\hline Devils Hole (AM-4) & USGS (NWIS) & $06 / 03 / 1984$ & - & - & - & - & - \\
\hline Devils Hole (AM-4) & USGS (NWIS) & $06 / 03 / 1984$ & - & - & - & - & - \\
\hline Devils Hole (AM-4) & USGS (NWIS) & 03/09/1985 & - & - & - & - & - \\
\hline Devils Hole (AM-4) & USGS (NWIS) & 03/09/1985 & - & - & - & - & - \\
\hline Devils Hole (AM-4) & USGS (NWIS) & 03/10/1985 & - & - & - & - & - \\
\hline Devils Hole (AM-4) & USGS (NWIS) & $05 / 05 / 1986$ & - & - & - & - & - \\
\hline Devils Hole (AM-4) & USGS (NWIS) & $05 / 05 / 1986$ & - & - & - & - & - \\
\hline Devils Hole (AM-4) & USGS (NWIS) & $11 / 16 / 1986$ & - & - & - & - & - \\
\hline Devils Hole (AM-4) & USGS (NWIS) & $11 / 16 / 1986$ & - & - & - & - & - \\
\hline Devils Hole (AM-4) & USGS (NWIS) & $06 / 22 / 1987$ & - & - & - & - & - \\
\hline Devils Hole (AM-4) & USGS (NWIS) & $06 / 22 / 1987$ & - & - & - & - & - \\
\hline Devils Hole (AM-4) & USGS (NWIS) & 03/16/1988 & - & - & - & - & - \\
\hline Devils Hole (AM-4) & USGS (NWIS) & $03 / 16 / 1988$ & - & - & - & - & - \\
\hline Devils Hole (AM-4) & USGS (NWIS) & $12 / 07 / 1988$ & - & - & - & - & - \\
\hline Devils Hole (AM-4) & USGS (NWIS) & $12 / 07 / 1988$ & - & - & - & - & - \\
\hline Devils Hole (AM-4) & USGS (NWIS) & $06 / 21 / 1989$ & - & - & - & - & - \\
\hline Devils Hole (AM-4) & USGS (NWIS) & $06 / 21 / 1989$ & - & - & - & - & - \\
\hline Devils Hole (AM-4) & USGS (NWIS) & $06 / 25 / 1990$ & - & - & - & - & - \\
\hline Devils Hole (AM-4) & USGS (NWIS) & $06 / 25 / 1990$ & - & - & - & - & - \\
\hline Devils Hole (AM-4) & USGS (NWIS) & $08 / 22 / 1990$ & - & - & - & - & - \\
\hline Devils Hole (AM-4) & USGS (NWIS) & 08/15/1991 & - & - & - & - & - \\
\hline Devils Hole (AM-4) & USGS (NWIS) & $08 / 27 / 1991$ & - & - & - & - & - \\
\hline Devils Hole (AM-4) & USGS (NWIS) & 08/19/1992 & - & - & - & - & - \\
\hline Devils Hole (AM-4) & USGS (NWIS) & 08/18/1999 & - & - & - & - & - \\
\hline Devils Hole (AM-4) & USGS (NWIS) & 08/18/1999 & - & - & - & - & - \\
\hline Devils Hole (AM-4) & USGS (NWIS) & 08/18/1999 & - & - & - & - & - \\
\hline Devils Hole (AM-4) & USGS (NWIS) & 09/23/1999 & - & - & - & - & - \\
\hline
\end{tabular}


[All significant figures reflective of what was reported by sources. Data from the U.S. Geological Survey (USGS) from the USGS National Water Information System (NWIS) database. All analyses are assumed to be reported filtered values. Abbreviations: BLS, below land surface; CA, California; E, estimated value; $\mathrm{HCO}_{3}$, bicarbonate; IC, inductively coupled; ICP, inductively coupled plasma; ICP-MS, inductively coupled plasma-mass spectrometry; ID, identification; M, detected but not quantified; mg/L, milligram per liter; mm/dd/yyyy, month/day/year; NAD83, North American Datum of 1983; NA, not applicable; ND, not detected; pMC, percent modern carbon; R, radiochemical non-detect; TU, tritium unit; UTM, Universal Transverse Mercator; $\mu \mathrm{g} / \mathrm{L}$, microgram per liter; $\mu \mathrm{S} / \mathrm{cm}$, microsiemens pe centimeter; ${ }^{\circ} \mathrm{C}$, degrees Celsius; $\%$, per mil; $\delta$, delta; $<$, less than; - , no data available]

\begin{tabular}{|c|c|c|c|c|c|c|c|}
\hline Site name & $\begin{array}{l}\text { Source } \\
\text { of data }\end{array}$ & $\begin{array}{c}\text { Sample } \\
\text { collection date } \\
\text { (mm/dd/yyyy) }\end{array}$ & $\begin{array}{c}\text { Tritium, } \\
\text { in TU }\end{array}$ & $\begin{array}{l}\delta^{2} \mathbf{H} \\
(\%)\end{array}$ & $\begin{array}{l}\delta^{18} 0 \\
(\%)\end{array}$ & $\begin{array}{c}\text { C14 } \\
\text { (pMC) }\end{array}$ & $\begin{array}{l}\delta^{13} \mathrm{C} \\
(\%)\end{array}$ \\
\hline Devils Hole (AM-4) & USGS (NWIS) & $09 / 10 / 2003$ & - & - & - & - & - \\
\hline Devils Hole (AM-4) & USGS (NWIS) & $09 / 10 / 2003$ & - & - & - & - & - \\
\hline Devils Hole (AM-4) & USGS (NWIS) & $09 / 27 / 2005$ & - & - & - & - & - \\
\hline Devils Hole (AM-4) & USGS (NWIS) & $09 / 27 / 2005$ & - & - & - & - & - \\
\hline Fairbanks Spring & Dudley and Larsen, 1976 & $11 / 1966$ & - & - & - & - & - \\
\hline Fairbanks Spring & Gomez and others, 2013 & - & - & -103.66 & -13.88 & 6.28 & -5.16 \\
\hline Fairbanks Spring & Hershey and others, 2010 & 03/17/1992 & $<10$ & -103.0 & -13.4 & 2.8 & -6.8 \\
\hline Fairbanks Spring & Thomas and others, 1996 & - & - & -103.0 & -13.8 & - & - \\
\hline Fairbanks Spring & USGS (NWIS) & 05/06/1997 & $<0.30$ & - & - & - & - \\
\hline Five Springs well (AM-2) & Gomez and others, 2013 & - & - & -103.75 & -14.19 & - & - \\
\hline Five Springs well (AM-2) & Source Group, Inc., 2011 & 05/01/2011 & $<1.2$ & -99.00 & -13.70 & - & - \\
\hline Five Springs well (AM-2) & USGS (NWIS) & 08/24/1990 & - & - & - & - & - \\
\hline Five Springs well (AM-2) & USGS (NWIS) & 04/28/1992 & - & -104.00 & -14.10 & - & - \\
\hline Five Springs well (AM-2) & USGS (NWIS) & $10 / 18 / 1994$ & - & - & - & - & - \\
\hline Five Springs well (AM-2) & USGS (NWIS) & 09/22/1996 & - & -104.00 & -13.57 & - & - \\
\hline Hog Farm well & Zdon and Associates, 2014 & $04 / 25 / 2013$ & - & - & - & - & - \\
\hline Point of Rocks Spring & Gomez and others, 2013 & - & - & -103.00 & -13.65 & 6.40 & -5.55 \\
\hline Point of Rocks Spring & Hershey and others, 2010 & - & - & -104.0 & -13.6 & - & - \\
\hline Tule Spring & Hershey, 1989 & $06 / 30 / 1985$ & $<5.0$ & -99 & -13.4 & 13.9 & -7 \\
\hline Tule Spring & USGS (NWIS) & $01 / 16 / 2013$ & $\mathrm{R}-0.3$ & -93.8 & -12.64 & 33.73 & - \\
\hline Resting Spring & Paces and others, 2002 & 03/11/1993 & - & - & - & - & - \\
\hline Resting Spring & Source Group, Inc., 2011 & $01 / 23 / 2011$ & - & - & - & - & - \\
\hline Resting Spring & Source Group, Inc., 2011 & $05 / 25 / 2011$ & $<1$ & -96.0 & -13.2 & - & - \\
\hline Twelvemile Spring & Zdon and Associates, 2014 & $04 / 25 / 2013$ & - & - & - & - & - \\
\hline Twelvemile Spring & Source Group, Inc., 2011 & $11 / 14 / 2010$ & - & - & - & - & - \\
\hline Twelvemile Spring & USGS (NWIS) & $03 / 21 / 2013$ & R0.1 & -95.5 & -13.02 & 11.07 & -6.1 \\
\hline Salsberry Spring & Paces and others, 2002 & 06/17/1998 & - & - & - & - & - \\
\hline Salsberry Spring & USGS (NWIS) & $03 / 11 / 2013$ & 14 & -87.41 & -11.18 & 104.40 & -10.80 \\
\hline
\end{tabular}


Table 9. Water chemistry of selected samples from the Lower Amargosa Valley and extra-basin contributing areas, California and Nevada.-Continued

[All significant figures reflective of what was reported by sources. Data from the U.S. Geological Survey (USGS) from the USGS National Water Information System (NWIS) database. All analyses are assumed to be reported filtered values. Abbreviations: BLS, below land surface; CA, California; E, estimated value; $\mathrm{HCO}_{3}$, bicarbonate; IC, inductively coupled; ICP, inductively coupled plasma;

ICP-MS, inductively coupled plasma-mass spectrometry; ID, identification; M, detected but not quantified; mg/L, milligram per liter; mm/dd/yyyy, month/day/year; NAD83, North American Datum of 1983; NA, not applicable; ND, not detected; pMC, percent modern carbon; R, radiochemical non-detect; TU, tritium unit; UTM, Universal Transverse Mercator; $\mu \mathrm{g} / \mathrm{L}$, microgram per liter; $\mu \mathrm{S} / \mathrm{cm}$, microsiemens per centimeter; ${ }^{\circ} \mathrm{C}$, degrees Celsius; \%o, per mil; $\delta$, delta; <, less than; - , no data available]

\begin{tabular}{|c|c|c|c|c|c|c|c|}
\hline Site name & $\begin{array}{l}\text { Source } \\
\text { of data }\end{array}$ & $\begin{array}{c}\text { Sample } \\
\text { collection date } \\
\text { (mm/dd/yyyy) }\end{array}$ & $\begin{array}{c}\text { Tritium, } \\
\text { in TU }\end{array}$ & $\begin{array}{l}\delta^{2} \mathbf{H} \\
(\%)\end{array}$ & $\begin{array}{l}\delta^{18} 0 \\
(\%)\end{array}$ & $\begin{array}{c}\text { C14 } \\
\text { (pMC) }\end{array}$ & $\begin{array}{l}\delta^{13} \mathbf{C} \\
(\%)\end{array}$ \\
\hline Crystal Spring & Drakos and Hodgins, 2013 & $03 / 14 / 2012$ & 2.3 & -92.40 & -12.65 & 88.4 & -13.2 \\
\hline Crystal Spring & Paces and others, 2002 & $02 / 05 / 1990$ & - & - & - & - & - \\
\hline Crystal Spring & Zdon and Associates, 2014 & $04 / 26 / 2011$ & - & - & - & - & - \\
\hline Crystal Spring & Zdon and Associates, 2014 & $04 / 27 / 2011$ & 0.90 & -82.0 & -10.8 & - & - \\
\hline Crystal Spring & USGS (NWIS) & 08/10/1994 & 0.19 & -103.5 & - & - & - \\
\hline Crystal Spring & USGS (NWIS) & 08/10/1994 & - & - & - & - & - \\
\hline Crystal Spring & USGS (NWIS) & 09/23/1996 & - & - & - & - & - \\
\hline Crystal Spring & USGS (NWIS) & 07/27/1998 & 0.77 & -105.0 & -13.8 & - & - \\
\hline Nevada National Security Site well & Gomez and others, 2013 & - & - & -107.5 & -14.0 & 2.24 & -4.70 \\
\hline 162 S20 E 5323 ABAD1 U19 & USGS (NWIS) & $11 / 07 / 2013$ & - & -99.70 & -13.52 & 28.76 & -7.38 \\
\hline Hidden Hills Ranch well & Hershey, 1989 & 07/30/1987 & $<5$ & -98.00 & -13.7 & 50.5 & -8.2 \\
\hline Jeep Trail well & Drakos and Hodgins, 2013 & 03/16/2012 & 0.3 & -100.70 & -13.57 & 40.5 & -8.8 \\
\hline NC-GWE-PV-04 & USGS (NWIS) & $06 / 27 / 2012$ & - & - & - & - & - \\
\hline NC-GWE-PV-04 & USGS (NWIS) & $10 / 15 / 2012$ & - & -97.76 & -13.38 & 18.14 & -7 \\
\hline Stump Spring well & Drakos and Hodgins, 2013 & $02 / 28 / 2012$ & 0.5 & -107.30 & -14.06 & 6.9 & -7.7 \\
\hline Stump Spring well & USGS (NWIS) & $06 / 22 / 2009$ & - & -107 & -14.62 & - & - \\
\hline Stump Spring well & USGS (NWIS) & $05 / 20 / 2010$ & - & - & - & - & - \\
\hline Black Mountain precipitation & USGS (NWIS) & $03 / 11 / 2013$ & - & -105.6 & -13.9 & - & - \\
\hline Kingston Range precipitation & USGS (NWIS) & $01 / 16 / 2013$ & - & -61.0 & -7.4 & - & - \\
\hline Mt Charleston precipitation & USGS (NWIS) & $05 / 23 / 2013$ & - & -81.2 & -11.7 & - & - \\
\hline Nopah Range precipitation & USGS (NWIS) & $03 / 19 / 2013$ & - & -78.4 & -9.2 & - & - \\
\hline Borax Spring & Larsen and others, 2001 & 01/03/1999 & - & -104 & -13.6 & - & - \\
\hline Borax Spring & Source Group, Inc., 2011 & $04 / 27 / 2011$ & $<0.9$ & -100.0 & -13.3 & - & - \\
\hline Borax Spring & Source Group, Inc., 2011 & $09 / 21 / 2011$ & - & - & - & - & - \\
\hline Chappo Spring & Paces and others, 2002 & 03/12/1993 & - & - & - & - & - \\
\hline Chappo Spring & Source Group, Inc., 2011 & $05 / 01 / 2011$ & $<1$ & -94.0 & -13.0 & - & 一 \\
\hline Chappo Spring & Larsen and others, 2001 & 01/05/1999 & - & -95 & -13 & - & - \\
\hline
\end{tabular}


[All significant figures reflective of what was reported by sources. Data from the U.S. Geological Survey (USGS) from the USGS National Water Information System (NWIS) database. All analyses are assumed to be reported filtered values. Abbreviations: BLS, below land surface; CA, California; E, estimated value; $\mathrm{HCO}_{3}$, bicarbonate; IC, inductively coupled; ICP, inductively coupled plasma; ICP-MS, inductively coupled plasma-mass spectrometry; ID, identification; M, detected but not quantified; mg/L, milligram per liter; mm/dd/yyyy, month/day/year; NAD83, North American Datum of 1983; NA, not applicable; ND, not detected; pMC, percent modern carbon; R, radiochemical non-detect; TU, tritium unit; UTM, Universal Transverse Mercator; $\mu \mathrm{g} / \mathrm{L}$, microgram per liter; $\mu \mathrm{S} / \mathrm{cm}$, microsiemens pe centimeter; ${ }^{\circ} \mathrm{C}$, degrees Celsius; $\%$, per mil; $\delta$, delta; $<$, less than; - , no data available]

\begin{tabular}{|c|c|c|c|c|c|c|c|}
\hline Site name & $\begin{array}{l}\text { Source } \\
\text { of data }\end{array}$ & $\begin{array}{c}\text { Sample } \\
\text { collection date } \\
\text { (mm/dd/yyyy) }\end{array}$ & $\begin{array}{c}\text { Tritium, } \\
\text { in TU }\end{array}$ & $\begin{array}{c}\delta^{2} \mathbf{H} \\
(\%)\end{array}$ & $\begin{array}{l}\delta^{18} 0 \\
(\%)\end{array}$ & $\begin{array}{c}\text { C14 } \\
\text { (pMC) }\end{array}$ & $\begin{array}{l}\delta^{13} \mathrm{C} \\
(\%)\end{array}$ \\
\hline Cynthia's well & Zdon and Associates, 2014 & $04 / 25 / 2013$ & - & - & - & - & - \\
\hline Cynthia's well & Source Group, Inc., 2011 & $05 / 11 / 2011$ & 1.20 & -93.00 & -12.20 & - & - \\
\hline Cynthia's well & Zdon and Associates, 2014 & $01 / 16 / 2011$ & - & - & - & - & - \\
\hline Shoshone Spring & Larsen and others, 2001 & $01 / 16 / 1962$ & - & - & - & - & - \\
\hline Shoshone Spring & Larsen and others, 2001 & $02 / 27 / 1976$ & - & - & - & - & - \\
\hline Shoshone Spring & Larsen and others, 2001 & 01/06/1997 & - & -95 & -12.6 & - & - \\
\hline Shoshone Spring & Source Group, Inc., 2011 & $01 / 23 / 2011$ & - & - & - & - & - \\
\hline Shoshone Spring & Source Group, Inc., 2011 & $04 / 27 / 2011$ & $<0.6$ & -93.0 & -12.6 & - & - \\
\hline Shoshone Spring & USGS (NWIS) & $03 / 10 / 1998$ & - & - & - & - & - \\
\hline Thom Spring & Source Group, Inc., 2011 & $11 / 11 / 2010$ & - & - & - & - & - \\
\hline Thom Spring & Source Group, Inc., 2011 & $04 / 27 / 2011$ & $<0.9$ & -95.0 & -13.1 & - & - \\
\hline Wild Bath Spring & USGS (NWIS) & 06/10/1998 & - & - & - & - & - \\
\hline Wild Bath Spring & Source Group, Inc., 2011 & $04 / 27 / 2011$ & $<0.6$ & -95.0 & -13.1 & - & - \\
\hline Wild Bath Spring & Source Group, Inc., 2011 & $09 / 21 / 2011$ & - & - & - & - & - \\
\hline Willow Spring & Hershey, 1989 & $06 / 26 / 1985$ & - & - & - & - & - \\
\hline Horse Springs & Drakos and Hodgins, 2013 & $03 / 05 / 2012$ & 0.7 & -99.60 & -13.35 & 45.5 & -10.6 \\
\hline Horse Springs & Paces and others, 2002 & $06 / 23 / 1993$ & - & - & - & - & - \\
\hline Lost Cabin Spring & Hershey, 1989 & $06 / 17 / 1987$ & 9.0 & -88.0 & -12.1 & - & - \\
\hline Lost Cabin Spring & USGS (NWIS) & $07 / 21 / 2009$ & - & -88.47 & -11.86 & - & - \\
\hline Lost Cabin Spring & USGS (NWIS) & $12 / 28 / 2009$ & - & - & - & - & - \\
\hline Lost Cabin Spring & USGS (NWIS) & $07 / 23 / 2010$ & 7 & - & - & - & - \\
\hline Peak Spring & Hershey, 1989 & $06 / 23 / 1987$ & 15.0 & -94.0 & -13.1 & 97.7 & -9.5 \\
\hline Peak Spring & USGS (NWIS) & $09 / 03 / 2008$ & - & - & - & - & - \\
\hline Peak Spring & USGS (NWIS) & $07 / 27 / 2009$ & - & -86.36 & -12.52 & - & - \\
\hline Peak Spring & USGS (NWIS) & $08 / 10 / 2010$ & - & - & - & - & - \\
\hline Rainbow Spring & Hershey, 1989 & $09 / 19 / 1982$ & $<5.0$ & -94.0 & -12.9 & 73.4 & -9.6 \\
\hline Rainbow Spring & Paces and others, 2002 & $06 / 23 / 1993$ & - & - & - & - & - \\
\hline Borehole Spring & Source Group, Inc., 2011 & $05 / 02 / 2011$ & $<1.1$ & -95.0 & -12.9 & - & - \\
\hline Borehole Spring & Source Group, Inc., 2011 & $09 / 21 / 2011$ & - & - & - & - & - \\
\hline
\end{tabular}


Table 9. Water chemistry of selected samples from the Lower Amargosa Valley and extra-basin contributing areas, California and Nevada.-Continued

[All significant figures reflective of what was reported by sources. Data from the U.S. Geological Survey (USGS) from the USGS National Water Information System (NWIS) database. All analyses are assumed to be reported filtered values. Abbreviations: BLS, below land surface; CA, California; E, estimated value; $\mathrm{HCO}_{3}$, bicarbonate; IC, inductively coupled; ICP, inductively coupled plasma;

ICP-MS, inductively coupled plasma-mass spectrometry; ID, identification; M, detected but not quantified; mg/L, milligram per liter; mm/dd/yyyy, month/day/year; NAD83, North American Datum of 1983; $\mathrm{NA}$, not applicable; ND, not detected; pMC, percent modern carbon; R, radiochemical non-detect; TU, tritium unit; UTM, Universal Transverse Mercator; $\mu \mathrm{g} / \mathrm{L}$, microgram per liter; $\mu \mathrm{S} / \mathrm{cm}$, microsiemens per centimeter; ${ }^{\circ} \mathrm{C}$, degrees Celsius; \%o, per mil; $\delta$, delta; $<$, less than; - , no data available]

\begin{tabular}{|c|c|c|c|c|c|c|c|c|}
\hline Site name & $\begin{array}{l}\text { Source } \\
\text { of data }\end{array}$ & $\begin{array}{c}\text { Sample } \\
\text { collection date } \\
\text { (mm/dd/yyyy) }\end{array}$ & $\begin{array}{l}\text { Tritium, } \\
\text { in TU }\end{array}$ & \multicolumn{2}{|c|}{$\begin{array}{l}\delta^{2} H \\
(\%)\end{array}$} & $\begin{array}{l}\delta^{18} 0 \\
(\%)\end{array}$ & $\begin{array}{c}\text { C14 } \\
\text { (pMC) }\end{array}$ & $\begin{array}{l}\delta^{13} \mathrm{C} \\
(\%)\end{array}$ \\
\hline Tecopa Hot Springs & Hershey and others, 2009 & $05 / 04 / 1992$ & $<10$ & \multicolumn{2}{|c|}{-98.0} & -12.7 & 2 & -6.3 \\
\hline Tecopa Hot Springs & Larsen and others, 2001 & 01/06/1997 & - & \multicolumn{2}{|c|}{-97.00} & -12.40 & - & - \\
\hline Tecopa Hot Springs & Source Group, Inc., 2011 & $04 / 27 / 2011$ & $<0.5$ & \multicolumn{2}{|c|}{-91.0} & -11.3 & - & - \\
\hline Tecopa Hot Springs & Source Group, Inc., 2011 & 09/21/2011 & - & \multicolumn{2}{|c|}{-} & - & - & - \\
\hline Tecopa Hot Springs & Steinkampf and Werrell, 2001 & $06 / 30 / 1985$ & $<1.0$ & \multicolumn{2}{|c|}{-98.0} & -12.85 & - & -4.3 \\
\hline \multirow{2}{*}{ Sites in Lower Amargosa Valley/extra-basin areas } & \multirow{2}{*}{ Source } & \multirow{2}{*}{$\begin{array}{c}\text { Sample } \\
\text { collection date } \\
\text { (mm/dd/yyyy) }\end{array}$} & $\begin{array}{c}\text { Decimal } \\
\text { longitude }\end{array}$ & $\begin{array}{l}\text { Decimal } \\
\text { latitude }\end{array}$ & \multirow{2}{*}{$\begin{array}{c}\text { Depth } \\
\text { (if } \\
\text { applicable, } \\
\text { in feet BLS) }\end{array}$} & $\begin{array}{c}\text { UTM } \\
\text { Easting }\end{array}$ & $\begin{array}{c}\text { UTM } \\
\text { Northing } \\
\end{array}$ & \multirow{2}{*}{ Group } \\
\hline & & & \multicolumn{2}{|c|}{ (assumed to be NAD83) } & & \multicolumn{2}{|c|}{$\begin{array}{c}\text { Zone } 11 \text { NAD83 } \\
\text { (in meters) }\end{array}$} & \\
\hline Amargosa Canyon Spring 1 & Source Group, Inc., 2011 & $04 / 25 / 2011$ & -116.22399 & 35.83937 & - & 570083 & 3966410 & Amargosa Canyon \\
\hline Amargosa Canyon Spring 1 & Source Group, Inc., 2011 & $12 / 22 / 2011$ & -116.22399 & 35.83937 & - & 570083 & 3966410 & Amargosa Canyon \\
\hline Amargosa Canyon Spring 4 & Source Group, Inc., 2011 & $04 / 25 / 2011$ & -116.22260 & 35.83480 & - & 570212 & 3965905 & Amargosa Canyon \\
\hline Amargosa Canyon Spring 4 & Source Group, Inc., 2011 & $12 / 22 / 2011$ & -116.22260 & 35.83480 & - & 570212 & 3965905 & Amargosa Canyon \\
\hline Willow Spring & Larsen and others, 2001 & 01/04/1999 & -116.18284 & 35.80556 & - & 573831 & 3962691 & Amargosa Canyon \\
\hline Willow Spring & Paces and others, 2002 & 03/11/1993 & -116.18284 & 35.80556 & - & 573831 & 3962691 & Amargosa Canyon \\
\hline Willow Spring & Source Group, Inc., 2011 & 04/26/2011 & -116.18284 & 35.80556 & - & 573831 & 3962691 & Amargosa Canyon \\
\hline Willow Spring & Source Group, Inc., 2011 & 09/23/2011 & -116.18284 & 35.80556 & - & 573831 & 3962691 & Amargosa Canyon \\
\hline Amargosa River (AR3314; Seepage Run) & USGS (NWIS) & $03 / 27 / 2014$ & -116.25901 & 35.90759 & - & 566863 & 3973952 & Amargosa River \\
\hline Amargosa River 2 & Source Group, Inc., 2011 & $11 / 17 / 2010$ & -116.22219 & 35.74637 & - & 570327 & 3956097 & Amargosa River \\
\hline Amargosa River 2 & Source Group, Inc., 2011 & 05/02/2011 & -116.22219 & 35.74637 & - & 570327 & 3956097 & Amargosa River \\
\hline Amargosa River at Tecopa, CA & USGS (NWIS) & 03/15/2005 & -116.22912 & 35.84861 & - & 569612 & 3967432 & Amargosa River \\
\hline Amargosa River at Tecopa, CA & USGS (NWIS) & $03 / 27 / 2014$ & -116.22912 & 35.84861 & - & 569612 & 3967432 & Amargosa River \\
\hline Amargosa River in Upper Canyon near Tecopa, CA & USGS (NWIS) & $03 / 15 / 2005$ & -116.22000 & 35.82556 & - & 570455 & 3964881 & Amargosa River \\
\hline Crystal Pool & Dudley and Larsen, 1976 & $11 / 1966$ & -116.32417 & 36.42028 & - & 560588 & 4030777 & Ash Meadows \\
\hline Crystal Pool & Gomez and others, 2013 & - & -116.32417 & 36.42028 & - & 560588 & 4030777 & Ash Meadows \\
\hline Crystal Pool & Hershey and others, 2010 & 03/17/1992 & -116.32417 & 36.42028 & - & 560588 & 4030777 & Ash Meadows \\
\hline Crystal Pool & USGS (NWIS) & 05/07/1997 & -116.32417 & 36.42028 & - & 560588 & 4030777 & Ash Meadows \\
\hline
\end{tabular}


[All significant figures reflective of what was reported by sources. Data from the U.S. Geological Survey (USGS) from the USGS National Water Information System (NWIS) database. All analyses are assumed to be reported filtered values. Abbreviations: BLS, below land surface; CA, California; E, estimated value; $\mathrm{HCO}_{3}$, bicarbonate; IC, inductively coupled; ICP, inductively coupled plasma; ICP-MS, inductively coupled plasma-mass spectrometry; ID, identification; M, detected but not quantified; mg/L, milligram per liter; mm/dd/yyyy, month/day/year; NAD83, North American Datum of 1983; NA, not applicable; ND, not detected; pMC, percent modern carbon; R, radiochemical non-detect; TU, tritium unit; UTM, Universal Transverse Mercator; $\mu \mathrm{g} / \mathrm{L}$, microgram per liter; $\mu \mathrm{S} / \mathrm{cm}$, microsiemens per centimeter; ${ }^{\circ} \mathrm{C}$, degrees Celsius; \%o, per mil; $\delta$, delta; <, less than; - , no data available]

\begin{tabular}{|c|c|c|c|c|c|c|c|c|}
\hline \multirow{2}{*}{ Sites in Lower Amargosa Valley/extra-basin areas } & \multirow{2}{*}{ Source } & \multirow{2}{*}{$\begin{array}{c}\text { Sample } \\
\text { collection date } \\
\text { (mm/dd/yyyy) }\end{array}$} & $\begin{array}{c}\text { Decimal } \\
\text { longitude }\end{array}$ & $\begin{array}{l}\text { Decimal } \\
\text { latitude }\end{array}$ & \multirow{2}{*}{$\begin{array}{c}\text { Depth } \\
\text { (if } \\
\text { applicable, } \\
\text { in feet BLS) }\end{array}$} & \multirow{2}{*}{\multicolumn{2}{|c|}{$\begin{array}{c}\begin{array}{c}\text { UTM } \\
\text { Easting }\end{array} \begin{array}{c}\text { UTM } \\
\text { Northing }\end{array} \\
\begin{array}{c}\text { Zone } 11 \text { NAD83 } \\
\text { (in meters) }\end{array}\end{array}$}} & \multirow{2}{*}{ Group } \\
\hline & & & \multicolumn{2}{|c|}{ (assumed to be NAD83) } & & & & \\
\hline Devils Hole (AM-4) & Thomas and others, 1996 & - & -116.29083 & 36.42556 & - & 563572 & 4031384 & Ash Meadows \\
\hline Devils Hole (AM-4) & Gomez and others, 2013 & - & -116.29083 & 36.42556 & - & 563572 & 4031384 & Ash Meadows \\
\hline Devils Hole (AM-4) & Hershey and others, 2009 & 07/09/1992 & -116.29083 & 36.42556 & - & 563572 & 4031384 & Ash Meadows \\
\hline Devils Hole (AM-4) & USGS (NWIS) & 06/03/1984 & -116.29083 & 36.42556 & - & 563572 & 4031384 & Ash Meadows \\
\hline Devils Hole (AM-4) & USGS (NWIS) & 06/03/1984 & -116.29083 & 36.42556 & - & 563572 & 4031384 & Ash Meadows \\
\hline Devils Hole (AM-4) & USGS (NWIS) & 03/09/1985 & -116.29083 & 36.42556 & - & 563572 & 4031384 & Ash Meadows \\
\hline Devils Hole (AM-4) & USGS (NWIS) & 03/09/1985 & -116.29083 & 36.42556 & - & 563572 & 4031384 & Ash Meadows \\
\hline Devils Hole (AM-4) & USGS (NWIS) & 03/10/1985 & -116.29083 & 36.42556 & - & 563572 & 4031384 & Ash Meadows \\
\hline Devils Hole (AM-4) & USGS (NWIS) & 05/05/1986 & -116.29083 & 36.42556 & - & 563572 & 4031384 & Ash Meadows \\
\hline Devils Hole (AM-4) & USGS (NWIS) & 05/05/1986 & -116.29083 & 36.42556 & - & 563572 & 4031384 & Ash Meadows \\
\hline Devils Hole (AM-4) & USGS (NWIS) & $11 / 16 / 1986$ & -116.29083 & 36.42556 & - & 563572 & 4031384 & Ash Meadows \\
\hline Devils Hole (AM-4) & USGS (NWIS) & $11 / 16 / 1986$ & -116.29083 & 36.42556 & - & 563572 & 4031384 & Ash Meadows \\
\hline Devils Hole (AM-4) & USGS (NWIS) & 06/22/1987 & -116.29083 & 36.42556 & - & 563572 & 4031384 & Ash Meadows \\
\hline Devils Hole (AM-4) & USGS (NWIS) & 06/22/1987 & -116.29083 & 36.42556 & - & 563572 & 4031384 & Ash Meadows \\
\hline Devils Hole (AM-4) & USGS (NWIS) & 03/16/1988 & -116.29083 & 36.42556 & - & 563572 & 4031384 & Ash Meadows \\
\hline Devils Hole (AM-4) & USGS (NWIS) & 03/16/1988 & -116.29083 & 36.42556 & - & 563572 & 4031384 & Ash Meadows \\
\hline Devils Hole (AM-4) & USGS (NWIS) & $12 / 07 / 1988$ & -116.29083 & 36.42556 & - & 563572 & 4031384 & Ash Meadows \\
\hline Devils Hole (AM-4) & USGS (NWIS) & $12 / 07 / 1988$ & -116.29083 & 36.42556 & - & 563572 & 4031384 & Ash Meadows \\
\hline Devils Hole (AM-4) & USGS (NWIS) & 06/21/1989 & -116.29083 & 36.42556 & - & 563572 & 4031384 & Ash Meadows \\
\hline Devils Hole (AM-4) & USGS (NWIS) & 06/21/1989 & -116.29083 & 36.42556 & - & 563572 & 4031384 & Ash Meadows \\
\hline Devils Hole (AM-4) & USGS (NWIS) & 06/25/1990 & -116.29083 & 36.42556 & - & 563572 & 4031384 & Ash Meadows \\
\hline Devils Hole (AM-4) & USGS (NWIS) & 06/25/1990 & -116.29083 & 36.42556 & - & 563572 & 4031384 & Ash Meadows \\
\hline Devils Hole (AM-4) & USGS (NWIS) & 08/22/1990 & -116.29083 & 36.42556 & - & 563572 & 4031384 & Ash Meadows \\
\hline Devils Hole (AM-4) & USGS (NWIS) & 08/15/1991 & -116.29083 & 36.42556 & - & 563572 & 4031384 & Ash Meadows \\
\hline Devils Hole (AM-4) & USGS (NWIS) & 08/27/1991 & -116.29083 & 36.42556 & - & 563572 & 4031384 & Ash Meadows \\
\hline Devils Hole (AM-4) & USGS (NWIS) & 08/19/1992 & -116.29083 & 36.42556 & - & 563572 & 4031384 & Ash Meadows \\
\hline Devils Hole (AM-4) & USGS (NWIS) & 08/18/1999 & -116.29083 & 36.42556 & - & 563572 & 4031384 & Ash Meadows \\
\hline
\end{tabular}


Table 9. Water chemistry of selected samples from the Lower Amargosa Valley and extra-basin contributing areas, California and Nevada.-Continued

[All significant figures reflective of what was reported by sources. Data from the U.S. Geological Survey (USGS) from the USGS National Water Information System (NWIS) database. All analyses are assumed to be reported filtered values. Abbreviations: BLS, below land surface; CA, California; E, estimated value; $\mathrm{HCO}_{3}$, bicarbonate; IC, inductively coupled; ICP, inductively coupled plasma;

ICP-MS, inductively coupled plasma-mass spectrometry; ID, identification; M, detected but not quantified; mg/L, milligram per liter; mm/dd/yyyy, month/day/year; NAD83, North American Datum of 1983; $\mathrm{NA}$, not applicable; ND, not detected; pMC, percent modern carbon; R, radiochemical non-detect; TU, tritium unit; UTM, Universal Transverse Mercator; $\mu \mathrm{g} / \mathrm{L}$, microgram per liter; $\mu \mathrm{S} / \mathrm{cm}$, microsiemens per centimeter; ${ }^{\circ} \mathrm{C}$, degrees Celsius; $\%$, per mil; $\delta$, delta; $<$, less than; —, no data available]

\begin{tabular}{|c|c|c|c|c|c|c|c|c|}
\hline \multirow{2}{*}{ Sites in Lower Amargosa Valley/extra-basin areas } & \multirow{2}{*}{ Source } & \multirow{2}{*}{$\begin{array}{c}\text { Sample } \\
\text { collection date } \\
\text { (mm/dd/yyyy) }\end{array}$} & $\begin{array}{l}\text { Decimal } \\
\text { longitude }\end{array}$ & $\begin{array}{l}\text { Decimal } \\
\text { latitude }\end{array}$ & \multirow{2}{*}{$\begin{array}{c}\text { Depth } \\
\text { (if } \\
\text { applicable, } \\
\text { in feet BLS) }\end{array}$} & $\begin{array}{c}\text { UTM } \\
\text { Easting }\end{array}$ & $\begin{array}{c}\text { UTM } \\
\text { Northing } \\
\end{array}$ & \multirow{2}{*}{ Group } \\
\hline & & & \multicolumn{2}{|c|}{ (assumed to be NAD83) } & & $\begin{array}{r}\text { Zone } 1 \\
\quad \text { (in } \mathrm{m}\end{array}$ & $\begin{array}{l}1 \text { NAD83 } \\
\text { leters) }\end{array}$ & \\
\hline Devils Hole (AM-4) & USGS (NWIS) & 08/18/1999 & -116.29083 & 36.42556 & - & 563572 & 4031384 & Ash Meadows \\
\hline Devils Hole (AM-4) & USGS (NWIS) & 08/18/1999 & -116.29083 & 36.42556 & - & 563572 & 4031384 & Ash Meadows \\
\hline Devils Hole (AM-4) & USGS (NWIS) & 09/23/1999 & -116.29083 & 36.42556 & - & 563572 & 4031384 & Ash Meadows \\
\hline Devils Hole (AM-4) & USGS (NWIS) & $09 / 10 / 2003$ & -116.29083 & 36.42556 & - & 563572 & 4031384 & Ash Meadows \\
\hline Devils Hole (AM-4) & USGS (NWIS) & $09 / 10 / 2003$ & -116.29083 & 36.42556 & - & 563572 & 4031384 & Ash Meadows \\
\hline Devils Hole (AM-4) & USGS (NWIS) & $09 / 27 / 2005$ & -116.29083 & 36.42556 & - & 563572 & 4031384 & Ash Meadows \\
\hline Devils Hole (AM-4) & USGS (NWIS) & $09 / 27 / 2005$ & -116.29083 & 36.42556 & - & 563572 & 4031384 & Ash Meadows \\
\hline Fairbanks Spring & Dudley and Larsen, 1976 & $11 / 1966$ & -116.39218 & 36.49049 & - & 554441 & 4038525 & Ash Meadows \\
\hline Fairbanks Spring & Gomez and others, 2013 & - & -116.39218 & 36.49049 & - & 554441 & 4038525 & Ash Meadows \\
\hline Fairbanks Spring & Hershey and others, 2010 & 03/17/1992 & -116.39218 & 36.49049 & - & 554441 & 4038525 & Ash Meadows \\
\hline Fairbanks Spring & Thomas and others, 1996 & - & -116.39218 & 36.49049 & - & 554441 & 4038525 & Ash Meadows \\
\hline Fairbanks Spring & USGS (NWIS) & 05/06/1997 & -116.39218 & 36.49049 & - & 554441 & 4038525 & Ash Meadows \\
\hline Five Springs well (AM-2) & Gomez and others, 2013 & - & -116.31923 & 36.46458 & 140 & 560996 & 4035694 & Ash Meadows \\
\hline Five Springs well (AM-2) & Source Group, Inc., 2011 & 05/01/2011 & -116.31923 & 36.46458 & 140 & 560996 & 4035694 & Ash Meadows \\
\hline Five Springs well (AM-2) & USGS (NWIS) & 08/24/1990 & -116.31923 & 36.46458 & 140 & 560996 & 4035694 & Ash Meadows \\
\hline Five Springs well (AM-2) & USGS (NWIS) & 04/28/1992 & -116.31923 & 36.46458 & 140 & 560996 & 4035694 & Ash Meadows \\
\hline Five Springs well (AM-2) & USGS (NWIS) & $10 / 18 / 1994$ & -116.31923 & 36.46458 & 140 & 560996 & 4035694 & Ash Meadows \\
\hline Five Springs well (AM-2) & USGS (NWIS) & 09/22/1996 & -116.31923 & 36.46458 & 140 & 560996 & 4035694 & Ash Meadows \\
\hline Hog Farm well & Zdon and Associates, 2014 & $04 / 25 / 2013$ & -116.37854 & 36.28748 & - & 555808 & 4016014 & Ash Meadows \\
\hline Point of Rocks Spring & Gomez and others, 2013 & - & -116.27250 & 36.39957 & - & 565237 & 4028514 & Ash Meadows \\
\hline Point of Rocks Spring & Hershey and others, 2010 & - & -116.27250 & 36.39957 & - & 565237 & 4028514 & Ash Meadows \\
\hline Tule Spring & Hershey, 1989 & 06/30/1985 & -116.05472 & 35.81694 & - & 585394 & 3964058 & California Valley \\
\hline Tule Spring & USGS (NWIS) & $01 / 16 / 2013$ & -116.05472 & 35.81694 & - & 585394 & 3964058 & California Valley \\
\hline Resting Spring & Paces and others, 2002 & 03/11/1993 & -116.15631 & 35.87732 & - & 576159 & 3970670 & Chicago Valley \\
\hline Resting Spring & Source Group, Inc., 2011 & $01 / 23 / 2011$ & -116.15631 & 35.87732 & - & 576159 & 3970670 & Chicago Valley \\
\hline Resting Spring & Source Group, Inc., 2011 & $05 / 25 / 2011$ & -116.15631 & 35.87732 & - & 576159 & 3970670 & Chicago Valley \\
\hline
\end{tabular}


[All significant figures reflective of what was reported by sources. Data from the U.S. Geological Survey (USGS) from the USGS National Water Information System (NWIS) database. All analyses are assumed to be reported filtered values. Abbreviations: BLS, below land surface; CA, California; E, estimated value; $\mathrm{HCO}_{3}$, bicarbonate; IC, inductively coupled; ICP, inductively coupled plasma; ICP-MS, inductively coupled plasma-mass spectrometry; ID, identification; M, detected but not quantified; mg/L, milligram per liter; mm/dd/yyyy, month/day/year; NAD83, North American Datum of 1983; NA, not applicable; ND, not detected; pMC, percent modern carbon; R, radiochemical non-detect; TU, tritium unit; UTM, Universal Transverse Mercator; $\mu \mathrm{g} / \mathrm{L}$, microgram per liter; $\mu \mathrm{S} / \mathrm{cm}$, microsiemens per centimeter; ${ }^{\circ} \mathrm{C}$, degrees Celsius; $\%$, per mil; $\delta$, delta; $<$, less than; - , no data available]

\begin{tabular}{|c|c|c|c|c|c|c|c|c|}
\hline \multirow{2}{*}{ Sites in Lower Amargosa Valley/extra-basin areas } & \multirow{2}{*}{ Source } & \multirow{2}{*}{$\begin{array}{c}\text { Sample } \\
\text { collection date } \\
\text { (mm/dd/yyyy) }\end{array}$} & $\begin{array}{c}\text { Decimal } \\
\text { longitude }\end{array}$ & $\begin{array}{l}\text { Decimal } \\
\text { latitude }\end{array}$ & \multirow{2}{*}{$\begin{array}{c}\text { Depth } \\
\text { (if } \\
\text { applicable, } \\
\text { in feet BLS) }\end{array}$} & $\begin{array}{c}\text { UTM } \\
\text { Easting }\end{array}$ & $\begin{array}{c}\text { UTM } \\
\text { Northing } \\
\end{array}$ & \multirow{2}{*}{ Group } \\
\hline & & & \multicolumn{2}{|c|}{ (assumed to be NAD83) } & & \multicolumn{2}{|c|}{$\begin{array}{c}\text { Zone } 11 \text { NAD83 } \\
\text { (in meters) }\end{array}$} & \\
\hline Twelvemile Spring & Zdon and Associates, 2014 & $04 / 25 / 2013$ & -116.15444 & 36.02167 & - & 576189 & 3986682 & Chicago Valley \\
\hline Twelvemile Spring & Source Group, Inc., 2011 & $11 / 14 / 2010$ & -116.15444 & 36.02167 & - & 576189 & 3986682 & Chicago Valley \\
\hline Twelvemile Spring & USGS (NWIS) & $03 / 21 / 2013$ & -116.15444 & 36.02167 & - & 576189 & 3986682 & Chicago Valley \\
\hline Salsberry Spring & Paces and others, 2002 & 06/17/1998 & -116.41869 & 35.93014 & - & 552439 & 3976356 & Greenwater Range \\
\hline Salsberry Spring & USGS (NWIS) & $03 / 11 / 2013$ & -116.41869 & 35.93014 & - & 552439 & 3976356 & Greenwater Range \\
\hline Crystal Spring & Drakos and Hodgins, 2013 & $03 / 14 / 2012$ & -115.96168 & 35.79469 & - & 593826 & 3961674 & Kingston Mountain \\
\hline Crystal Spring & Paces and others, 2002 & $02 / 05 / 1990$ & -115.96168 & 35.79469 & - & 593826 & 3961674 & Kingston Mountain \\
\hline Crystal Spring & Zdon and Associates, 2014 & $04 / 26 / 2011$ & -115.96168 & 35.79469 & - & 593826 & 3961674 & Kingston Mountain \\
\hline Crystal Spring & Zdon and Associates, 2014 & $04 / 27 / 2011$ & -115.96168 & 35.79469 & - & 593826 & 3961674 & Kingston Mountain \\
\hline Crystal Spring & USGS (NWIS) & 08/10/1994 & -115.96168 & 35.79469 & - & 593826 & 3961674 & Kingston Mountain \\
\hline Crystal Spring & USGS (NWIS) & 08/10/1994 & -115.96168 & 35.79469 & - & 593826 & 3961674 & Kingston Mountain \\
\hline Crystal Spring & USGS (NWIS) & 09/23/1996 & -115.96168 & 35.79469 & - & 593826 & 3961674 & Kingston Mountain \\
\hline Crystal Spring & USGS (NWIS) & 07/27/1998 & -115.96168 & 35.79469 & - & 593826 & 3961674 & Kingston Mountain \\
\hline Nevada National Security Site well & Gomez and others, 2013 & - & -115.99286 & 36.98263 & - & 589633 & 4093419 & $\begin{array}{l}\text { Nevada National } \\
\text { Security Site }\end{array}$ \\
\hline 162 S20 E 5323 ABAD1 U19 & USGS (NWIS) & $11 / 07 / 2013$ & -115.96667 & 36.20000 & 430 & 592898 & 4006627 & Pahrump \\
\hline Hidden Hills Ranch well & Hershey, 1989 & 07/30/1987 & -115.86502 & 36.01414 & - & 602277 & 3986112 & Pahrump \\
\hline Jeep Trail well & Drakos and Hodgins, 2013 & $03 / 16 / 2012$ & -115.76802 & 36.00479 & $<160$ & 611032 & 3985181 & Pahrump \\
\hline NC-GWE-PV-04 & USGS (NWIS) & $06 / 27 / 2012$ & -116.03748 & 36.16445 & 150.3 & 586571 & 4002617 & Pahrump \\
\hline NC-GWE-PV-04 & USGS (NWIS) & $10 / 15 / 2012$ & -116.03748 & 36.16445 & 150.3 & 586571 & 4002617 & Pahrump \\
\hline Stump Spring well & Drakos and Hodgins, 2013 & $02 / 28 / 2012$ & -115.81917 & 35.99472 & 120 & 606436 & 3984008 & Pahrump \\
\hline Stump Spring well & USGS (NWIS) & $06 / 22 / 2009$ & -115.81917 & 35.99472 & 120 & 606436 & 3984008 & Pahrump \\
\hline Stump Spring well & USGS (NWIS) & $05 / 20 / 2010$ & -115.81917 & 35.99472 & 120 & 606436 & 3984008 & Pahrump \\
\hline Black Mountain precipitation & USGS (NWIS) & $03 / 11 / 2013$ & -116.46472 & 35.87868 & - & 548318 & 3970625 & Precipitation \\
\hline Kingston Range precipitation & USGS (NWIS) & $01 / 16 / 2013$ & -115.94329 & 35.78871 & - & 595495 & 3961029 & Precipitation \\
\hline Mt Charleston precipitation & USGS (NWIS) & $05 / 23 / 2013$ & -115.66944 & 36.28806 & - & 619486 & 4016720 & Precipitation \\
\hline Nopah Range precipitation & USGS (NWIS) & $03 / 19 / 2013$ & -116.05798 & 35.88285 & - & 585029 & 3971365 & Precipitation \\
\hline
\end{tabular}


Table 9. Water chemistry of selected samples from the Lower Amargosa Valley and extra-basin contributing areas, California and Nevada.-Continued

[All significant figures reflective of what was reported by sources. Data from the U.S. Geological Survey (USGS) from the USGS National Water Information System (NWIS) database. All analyses are assumed to be reported filtered values. Abbreviations: BLS, below land surface; CA, California; E, estimated value; $\mathrm{HCO}_{3}$, bicarbonate; IC, inductively coupled; ICP, inductively coupled plasma;

ICP-MS, inductively coupled plasma-mass spectrometry; ID, identification; M, detected but not quantified; mg/L, milligram per liter; mm/dd/yyyy, month/day/year; NAD83, North American Datum of 1983; $\mathrm{NA}$, not applicable; ND, not detected; pMC, percent modern carbon; R, radiochemical non-detect; TU, tritium unit; UTM, Universal Transverse Mercator; $\mu \mathrm{g} / \mathrm{L}$, microgram per liter; $\mu \mathrm{S} / \mathrm{cm}$, microsiemens per centimeter; ${ }^{\circ} \mathrm{C}$, degrees Celsius; $\%$, per mil; $\delta$, delta; $<$, less than; —, no data available]

\begin{tabular}{|c|c|c|c|c|c|c|c|c|}
\hline \multirow{2}{*}{ Sites in Lower Amargosa Valley/extra-basin areas } & \multirow{2}{*}{ Source } & \multirow{2}{*}{$\begin{array}{c}\text { Sample } \\
\text { collection date } \\
\text { (mm/dd/yyyy) }\end{array}$} & $\begin{array}{l}\text { Decimal } \\
\text { Iongitude }\end{array}$ & $\begin{array}{l}\text { Decimal } \\
\text { latitude }\end{array}$ & \multirow{2}{*}{$\begin{array}{c}\text { Depth } \\
\text { (if } \\
\text { applicable, } \\
\text { in feet BLS) }\end{array}$} & $\begin{array}{c}\text { UTM } \\
\text { Easting }\end{array}$ & $\begin{array}{c}\text { UTM } \\
\text { Northing }\end{array}$ & \multirow{2}{*}{ Group } \\
\hline & & & \multicolumn{2}{|c|}{ (assumed to be NAD83) } & & $\begin{array}{l}\text { Zone } 1 \\
\quad \text { (in } \mathrm{m}\end{array}$ & $\begin{array}{l}1 \text { NAD83 } \\
\text { leters) }\end{array}$ & \\
\hline Borax Spring & Larsen and others, 2001 & 01/03/1999 & -116.25806 & 35.88814 & - & 566965 & 3971796 & Shoshone and Tecopa \\
\hline Borax Spring & Source Group, Inc., 2011 & 04/27/2011 & -116.25806 & 35.88814 & - & 566965 & 3971796 & Shoshone and Tecopa \\
\hline Borax Spring & Source Group, Inc., 2011 & $09 / 21 / 2011$ & -116.25806 & 35.88814 & - & 566965 & 3971796 & Shoshone and Tecopa \\
\hline Chappo Spring & Paces and others, 2002 & 03/12/1993 & -116.18833 & 35.94722 & - & 573204 & 3978399 & Shoshone and Tecopa \\
\hline Chappo Spring & Source Group, Inc., 2011 & 05/01/2011 & -116.18833 & 35.94722 & - & 573204 & 3978399 & Shoshone and Tecopa \\
\hline Chappo Spring & Larsen and others, 2001 & 01/05/1999 & -116.18833 & 35.94722 & - & 573204 & 3978399 & Shoshone and Tecopa \\
\hline Cynthia's well & Zdon and Associates, 2014 & $04 / 25 / 2013$ & -116.20478 & 35.84610 & unknown & 571812 & 3967171 & Shoshone and Tecopa \\
\hline Cynthia's well & Source Group, Inc., 2011 & $05 / 11 / 2011$ & -116.20478 & 35.84610 & unknown & 571812 & 3967171 & Shoshone and Tecopa \\
\hline Cynthia's well & Zdon and Associates, 2014 & 01/16/2011 & -116.20478 & 35.84610 & unknown & 571812 & 3967171 & Shoshone and Tecopa \\
\hline Shoshone Spring & Larsen and others, 2001 & $01 / 16 / 1962$ & -116.27308 & 35.98052 & - & 565533 & 3982032 & Shoshone and Tecopa \\
\hline Shoshone Spring & Larsen and others, 2001 & 02/27/1976 & -116.27308 & 35.98052 & - & 565533 & 3982032 & Shoshone and Tecopa \\
\hline Shoshone Spring & Larsen and others, 2001 & 01/06/1997 & -116.27308 & 35.98052 & - & 565533 & 3982032 & Shoshone and Tecopa \\
\hline Shoshone Spring & Source Group, Inc., 2011 & 01/23/2011 & -116.27308 & 35.98052 & - & 565533 & 3982032 & Shoshone and Tecopa \\
\hline Shoshone Spring & Source Group, Inc., 2011 & 04/27/2011 & -116.27308 & 35.98052 & - & 565533 & 3982032 & Shoshone and Tecopa \\
\hline Shoshone Spring & USGS (NWIS) & 03/10/1998 & -116.27308 & 35.98052 & - & 565533 & 3982032 & Shoshone and Tecopa \\
\hline Thom Spring & Source Group, Inc., 2011 & $11 / 11 / 2010$ & -116.22677 & 35.85661 & - & 569817 & 3968321 & Shoshone and Tecopa \\
\hline Thom Spring & Source Group, Inc., 2011 & 04/27/2011 & -116.22677 & 35.85661 & - & 569817 & 3968321 & Shoshone and Tecopa \\
\hline Wild Bath Spring & USGS (NWIS) & 06/10/1998 & -116.21932 & 35.87277 & - & 570475 & 3970118 & Shoshone and Tecopa \\
\hline Wild Bath Spring & Source Group, Inc., 2011 & $04 / 27 / 2011$ & -116.21932 & 35.87277 & - & 570475 & 3970118 & Shoshone and Tecopa \\
\hline Wild Bath Spring & Source Group, Inc., 2011 & 09/21/2011 & -116.21932 & 35.87277 & - & 570475 & 3970118 & Shoshone and Tecopa \\
\hline Willow Spring & Hershey, 1989 & $06 / 26 / 1985$ & -116.21932 & 35.87277 & - & 570475 & 3970118 & Shoshone and Tecopa \\
\hline Horse Springs & Drakos and Hodgins, 2013 & 03/05/2012 & -115.87083 & 36.29722 & - & 601388 & 4017507 & Spring Mountains \\
\hline Horse Springs & Paces and others, 2002 & $06 / 23 / 1993$ & -115.87083 & 36.29722 & - & 601388 & 4017507 & Spring Mountains \\
\hline Lost Cabin Spring & Hershey, 1989 & 06/17/1987 & -115.65300 & 36.08300 & - & 621279 & 3993994 & Spring Mountains \\
\hline Lost Cabin Spring & USGS (NWIS) & 07/21/2009 & -115.65300 & 36.08300 & - & 621279 & 3993994 & Spring Mountains \\
\hline Lost Cabin Spring & USGS (NWIS) & $12 / 28 / 2009$ & -115.65300 & 36.08300 & - & 621279 & 3993994 & Spring Mountains \\
\hline Lost Cabin Spring & USGS (NWIS) & $07 / 23 / 2010$ & -115.65300 & 36.08300 & - & 621279 & 3993994 & Spring Mountains \\
\hline
\end{tabular}


[All significant figures reflective of what was reported by sources. Data from the U.S. Geological Survey (USGS) from the USGS National Water Information System (NWIS) database. All analyses are assumed to be reported filtered values. Abbreviations: BLS, below land surface; CA, California; E, estimated value; $\mathrm{HCO}_{3}$, bicarbonate; IC, inductively coupled; ICP, inductively coupled plasma; ICP-MS, inductively coupled plasma-mass spectrometry; ID, identification; M, detected but not quantified; mg/L, milligram per liter; mm/dd/yyyy, month/day/year; NAD83, North American Datum of 1983; NA, not applicable; ND, not detected; pMC, percent modern carbon; R, radiochemical non-detect; TU, tritium unit; UTM, Universal Transverse Mercator; $\mu \mathrm{g} / \mathrm{L}$, microgram per liter; $\mu \mathrm{S} / \mathrm{cm}$, microsiemens pe centimeter; ${ }^{\circ} \mathrm{C}$, degrees Celsius; \%o, per mil; $\delta$, delta; <, less than; - , no data available]

\begin{tabular}{|c|c|c|c|c|c|c|c|c|}
\hline \multirow{2}{*}{ Sites in Lower Amargosa Valley/extra-basin areas } & \multirow{2}{*}{ Source } & \multirow{2}{*}{$\begin{array}{c}\text { Sample } \\
\text { collection date } \\
\text { (mm/dd/yyyy) }\end{array}$} & $\begin{array}{c}\text { Decimal } \\
\text { longitude }\end{array}$ & $\begin{array}{l}\text { Decimal } \\
\text { latitude }\end{array}$ & \multirow{2}{*}{$\begin{array}{c}\text { Depth } \\
\text { (if } \\
\text { applicable, } \\
\text { in feet BLS) }\end{array}$} & $\begin{array}{c}\text { UTM } \\
\text { Easting }\end{array}$ & $\begin{array}{c}\text { UTM } \\
\text { Northing } \\
\end{array}$ & \multirow{2}{*}{ Group } \\
\hline & & & \multicolumn{2}{|c|}{$\overline{\text { (assumed to be NAD83) }}$} & & \multicolumn{2}{|c|}{$\begin{array}{l}\text { Zone } 11 \text { NAD83 } \\
\text { (in meters) }\end{array}$} & \\
\hline Peak Spring & Hershey, 1989 & $06 / 23 / 1987$ & -115.69736 & 36.26149 & - & 617019 & 4013739 & Spring Mountains \\
\hline Peak Spring & USGS (NWIS) & $09 / 03 / 2008$ & -115.69736 & 36.26149 & - & 617019 & 4013739 & Spring Mountains \\
\hline Peak Spring & USGS (NWIS) & 07/27/2009 & -115.69736 & 36.26149 & - & 617019 & 4013739 & Spring Mountains \\
\hline Peak Spring & USGS (NWIS) & $08 / 10 / 2010$ & -115.69736 & 36.26149 & - & 617019 & 4013739 & Spring Mountains \\
\hline Rainbow Spring & Hershey, 1989 & $09 / 19 / 1982$ & -115.50889 & 36.05278 & - & 634306 & 3990831 & Spring Mountains \\
\hline Rainbow Spring & Paces and others, 2002 & $06 / 23 / 1993$ & -115.50889 & 36.05278 & - & 634306 & 3990831 & Spring Mountains \\
\hline Borehole Spring & Source Group, Inc., 2011 & $05 / 02 / 2011$ & -116.23416 & 35.88608 & 350 & 569124 & 3971584 & Tecopa Hot Springs \\
\hline Borehole Spring & Source Group, Inc., 2011 & $09 / 21 / 2011$ & -116.23416 & 35.88608 & 350 & 569124 & 3971584 & Tecopa Hot Springs \\
\hline Tecopa Hot Springs & Hershey and others, 2009 & 05/04/1992 & -116.23141 & 35.87191 & - & 569384 & 3970014 & Tecopa Hot Springs \\
\hline Tecopa Hot Springs & Larsen and others, 2001 & 01/06/1997 & -116.23141 & 35.87191 & - & 569384 & 3970014 & Tecopa Hot Springs \\
\hline Tecopa Hot Springs & Source Group, Inc., 2011 & $04 / 27 / 2011$ & -116.23141 & 35.87191 & - & 569384 & 3970014 & Tecopa Hot Springs \\
\hline Tecopa Hot Springs & Source Group, Inc., 2011 & $09 / 21 / 2011$ & -116.23141 & 35.87191 & - & 569384 & 3970014 & Tecopa Hot Springs \\
\hline Tecopa Hot Springs & Steinkampf and Werrell, 2001 & $06 / 30 / 1985$ & -116.23141 & 35.87191 & - & 569384 & 3970014 & Tecopa Hot Springs \\
\hline
\end{tabular}

Tecopa Hot Springs 
Table 10. Selected chemistry of representative samples used in geochemical analysis and modeling, Lower Amargosa Valley and extra-basin contributing areas, California and Nevada.

[B, boron; Ca, calcium; Cl, chloride; $\mathrm{HCO}_{3}$, bicarbonate, $\mathrm{Mg}$, magnesium; mg/L, milligram per liter; Na, sodium; NAD83, North American Datum of 1983; pMC, percent modern carbon; $\mathrm{SO}$, sulfate; Sr, strontium; TU, tritium unit; UTM, Universal Transverse Mercator; $\mu \mathrm{g} / \mathrm{L}$, microgram per liter; $\mu \mathrm{S} / \mathrm{cm}$, microsiemens per centimeter; $\%$, per mil; ${ }^{\circ} \mathrm{C}$, degrees Celsius; $<$, less than; - , no data available]

\begin{tabular}{|c|c|c|c|c|c|c|c|c|c|}
\hline Site name & $\begin{array}{c}\text { Site } \\
\text { reference } \\
\text { number }\end{array}$ & Group & $\begin{array}{c}\text { Water } \\
\text { temperature } \\
\left({ }^{\circ} \mathrm{C}\right)\end{array}$ & $\begin{array}{c}\text { Specific } \\
\text { conductance } \\
(\mu \mathrm{S} / \mathrm{cm} \text { at } \\
\left.25^{\circ} \mathrm{C}\right)\end{array}$ & $\begin{array}{c}\text { Dissolved } \\
\text { oxygen } \\
\text { (mg/L) }\end{array}$ & $\begin{array}{l}\text { Total } \\
\text { dissolved } \\
\text { solids } \\
\text { (mg/L) }\end{array}$ & $\mathrm{pH}$ & Water type & $\begin{array}{c}\text { Alkalinity } \\
\text { (mg/L as } \\
\mathrm{HCO}_{3} \text { ) }\end{array}$ \\
\hline Amargosa Canyon Spring 1 & 1 & Amargosa Canyon & 23 & 1,000 & 8.0 & 650 & 8.2 & $\mathrm{Na}-\mathrm{Mg}-\mathrm{HCO}_{3}-\mathrm{SO}_{4}$ & 290 \\
\hline Amargosa Canyon Spring 4 & 2 & Amargosa Canyon & 26 & 1,300 & 8.6 & 780 & 8.3 & $\mathrm{Na}-\mathrm{HCO}_{3}-\mathrm{SO}_{4}$ & 380 \\
\hline Willow Spring & 3 & Amargosa Canyon & 24 & 1,000 & 8.1 & 740 & 8.3 & $\mathrm{Na}-\mathrm{Mg}-\mathrm{Ca}-\mathrm{HCO}_{3}-\mathrm{SO}_{4}$ & 290 \\
\hline Amargosa River (AR3314; seepage run) & 4 & Amargosa River & 10 & - & 9.0 & - & 7.5 & $\mathrm{Na}-\mathrm{Cl}-\mathrm{SO}_{4}$ & 1,600 \\
\hline Amargosa River 2 & 5 & Amargosa River & 21 & 4,300 & 8.6 & 2,800 & 8.9 & $\mathrm{Na}-\mathrm{SO}_{4}-\mathrm{HCO}_{3}-\mathrm{Cl}$ & 720 \\
\hline Amargosa River at Tecopa, CA & 6 & Amargosa River & 13 & 8,200 & 14 & - & 8.1 & $\mathrm{Na}-\mathrm{SO}_{4}-\mathrm{HCO}_{3}-\mathrm{Cl}$ & 1,600 \\
\hline Amargosa River in Upper Canyon near Tecopa, CA & 7 & Amargosa River & 21 & 3,300 & 10 & - & 8.7 & $\mathrm{Na}-\mathrm{SO}_{4}-\mathrm{HCO}_{3}-\mathrm{Cl}$ & 580 \\
\hline Crystal Pool & 8 & Ash Meadows & 31 & 710 & 3.7 & 430 & 7.3 & $\mathrm{Na}-\mathrm{Ca}-\mathrm{Mg}-\mathrm{HCO}_{3}-\mathrm{SO}_{4}$ & 310 \\
\hline Devils Hole (AM-4) & 9 & Ash Meadows & 33 & 700 & 2.9 & 420 & 6.9 & $\mathrm{Na}-\mathrm{Ca}-\mathrm{Mg}-\mathrm{HCO}_{3}-\mathrm{SO}_{4}$ & 210 \\
\hline Fairbanks Spring & 10 & Ash Meadows & 27 & 690 & 3.2 & 580 & 7.4 & $\mathrm{Na}-\mathrm{Ca}-\mathrm{Mg}-\mathrm{HCO}_{3}-\mathrm{SO}_{4}$ & 310 \\
\hline Five Springs well (AM-2) & 11 & Ash Meadows & 34 & 700 & 4.4 & 450 & 7.6 & $\mathrm{Na}-\mathrm{Ca}-\mathrm{Mg}-\mathrm{HCO}_{3}-\mathrm{SO}_{4}$ & 320 \\
\hline Hog Farm well & 12 & Ash Meadows & - & 1,500 & - & 860 & - & $\mathrm{Na}-\mathrm{HCO}_{3}-\mathrm{SO}_{4}$ & 470 \\
\hline Point of Rocks Spring & 13 & Ash Meadows & 32 & 670 & - & 580 & 7.2 & $\mathrm{Ca}-\mathrm{Mg}-\mathrm{Na}-\mathrm{HCO}_{3}-\mathrm{SO}_{4}$ & 310 \\
\hline Tule Spring & 14 & California Valley & 8.9 & 820 & 1.9 & 540 & 7.4 & $\mathrm{Ca}-\mathrm{HCO}_{3}$ & 2,500 \\
\hline Twelvemile Spring & 15 & Chicago Valley & 19 & 800 & 1.4 & 480 & 7.6 & $\mathrm{Na}-\mathrm{Ca}-\mathrm{Mg}-\mathrm{HCO}_{3}-\mathrm{SO}_{4}$ & 180 \\
\hline Resting Spring & 16 & Chicago Valley & 27 & 920 & 5.6 & 580 & 8.4 & $\mathrm{Na}-\mathrm{HCO}_{3}$ & 240 \\
\hline Salsberry Spring & 17 & Greenwater Range & 12 & 310 & - & 290 & 8.3 & $\mathrm{Na}-\mathrm{HCO}_{3}$ & 1,300 \\
\hline Crystal Spring & 18 & Kingston Range & 11 & 480 & 5.7 & 290 & 6.9 & $\mathrm{Ca}-\mathrm{Mg}-\mathrm{HCO}_{3}$ & 240 \\
\hline Nevada National Security Site well & 19 & $\begin{array}{c}\text { Nevada National } \\
\text { Security Site }\end{array}$ & 41 & 490 & - & - & 7.3 & $\mathrm{Na}-\mathrm{Ca}-\mathrm{HCO}_{3}$ & 240 \\
\hline 162 S20 E 5323 ABAD1 U19 & 20 & Pahrump Valley & 24 & 410 & 5.9 & - & 7.1 & $\mathrm{Ca}-\mathrm{Mg}-\mathrm{HCO}_{3}$ & 190 \\
\hline Hidden Hills Ranch well & 21 & Pahrump Valley & 24 & 480 & - & 300 & 7.2 & $\mathrm{Ca}-\mathrm{Mg}-\mathrm{HCO}_{3}$ & 230 \\
\hline Jeep Trail well & 22 & Pahrump Valley & 23 & 350 & 7.1 & 220 & 7.8 & $\mathrm{Ca}-\mathrm{Mg}-\mathrm{HCO}_{3}$ & 120 \\
\hline NC-GWE-PV-04 & 23 & Pahrump Valley & 22 & 530 & 6.8 & 250 & 7.9 & $\mathrm{Ca}-\mathrm{HCO}_{3}$ & 216 \\
\hline Stump Spring well & 24 & Pahrump Valley & 24 & 320 & 5.5 & 210 & 7.5 & $\mathrm{Mg}-\mathrm{Ca}-\mathrm{HCO}_{3}$ & 110 \\
\hline Black Mountain precipitation & 25 & Precipitation & - & - & - & - & - & - & - \\
\hline Kingston Range precipitation & 26 & Precipitation & - & - & - & - & - & - & - \\
\hline Mt. Charleston precipitation & 27 & Precipitation & - & - & - & - & - & - & - \\
\hline
\end{tabular}


Table 10. Selected chemistry of representative samples used in geochemical analysis and modeling, Lower Amargosa Valley and extra-basin contributing areas, California and Nevada.-Continued

[B, boron; Ca, calcium; $\mathrm{Cl}$, chloride; $\mathrm{HCO}_{3}$, bicarbonate, $\mathrm{Mg}$, magnesium; mg/L, milligram per liter; Na, sodium; NAD83, North American Datum of 1983; pMC, percent modern carbon; $\mathrm{SO}$, sulfate; Sr, strontium; TU, tritium unit; UTM, Universal Transverse Mercator; $\mu \mathrm{g} / \mathrm{L}$, microgram per liter; $\mu \mathrm{S} / \mathrm{cm}$, microsiemens per centimeter; \% $\%$ per mil; ${ }^{\circ} \mathrm{C}$, degrees Celsius; $<$, less than; - , no data available]

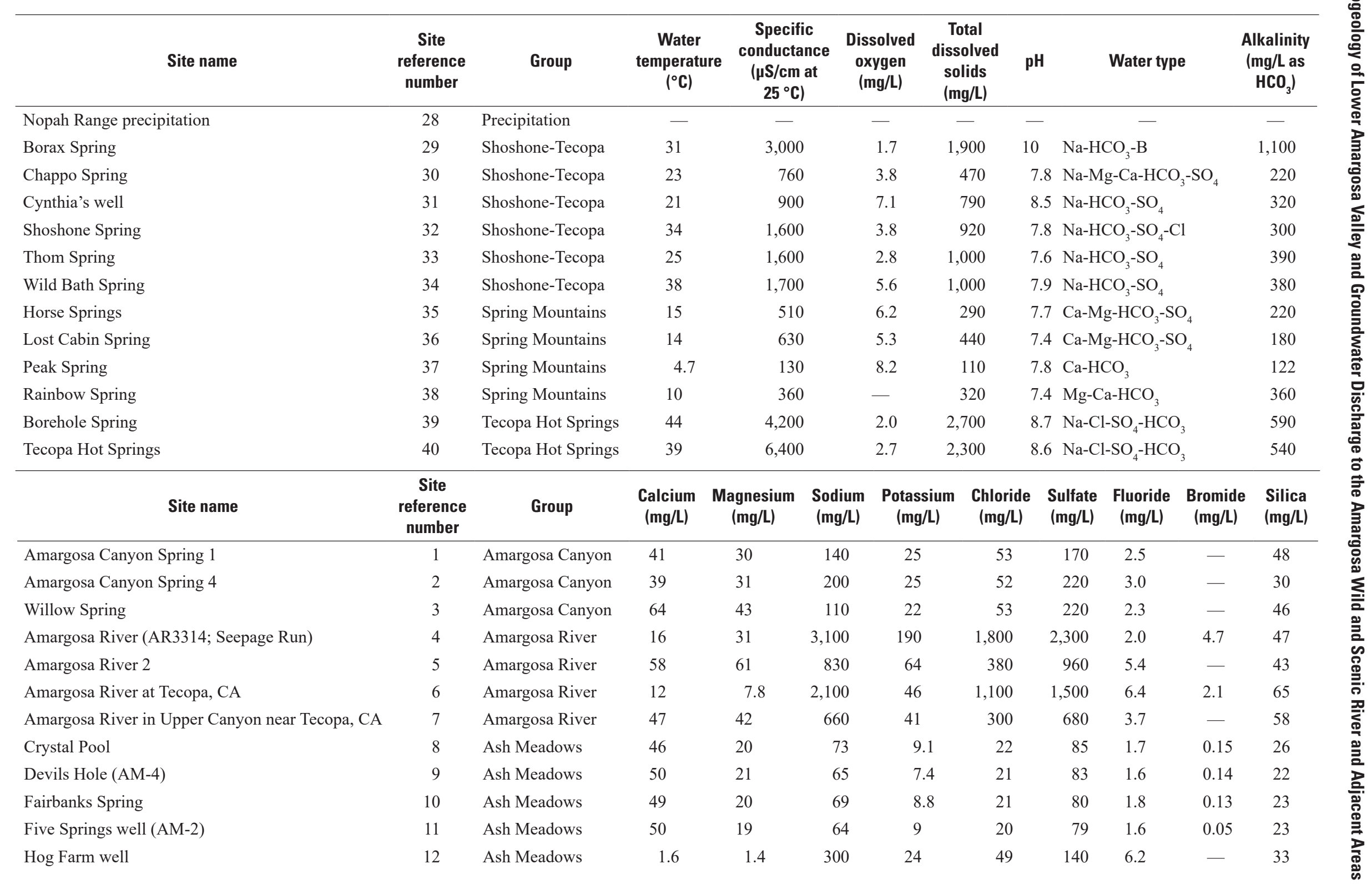


Table 10. Selected chemistry of representative samples used in geochemical analysis and modeling, Lower Amargosa Valley and extra-basin contributing areas, California and Nevada.-Continued

[B, boron; Ca, calcium; Cl, chloride; $\mathrm{HCO}_{3}$, bicarbonate, $\mathrm{Mg}$, magnesium; mg/L, milligram per liter; $\mathrm{Na}$, sodium; NAD83, North American Datum of 1983; pMC, percent modern carbon; $\mathrm{SO}$, sulfate; Sr, strontium; TU, tritium unit; UTM, Universal Transverse Mercator; $\mu \mathrm{g} / \mathrm{L}$, microgram per liter; $\mu \mathrm{S} / \mathrm{cm}$, microsiemens per centimeter; \%o, per mil; ${ }^{\circ} \mathrm{C}$, degrees Celsius; $<$, less than; - , no data available]

\begin{tabular}{|c|c|c|c|c|c|c|c|c|c|c|c|}
\hline Site name & $\begin{array}{c}\text { Site } \\
\text { reference } \\
\text { number }\end{array}$ & Group & $\begin{array}{l}\text { Calcium } \\
\text { (mg/L) }\end{array}$ & $\begin{array}{l}\text { Magnesium } \\
(\mathrm{mg} / \mathrm{L})\end{array}$ & $\begin{array}{l}\text { Sodium } \\
\text { (mg/L) }\end{array}$ & $\begin{array}{l}\text { Potassium } \\
\text { (mg/L) }\end{array}$ & $\begin{array}{l}\text { Chloride } \\
\text { (mg/L) }\end{array}$ & $\begin{array}{l}\text { Sulfate } \\
\text { (mg/L) }\end{array}$ & $\begin{array}{l}\text { Fluoride } \\
\text { (mg/L) }\end{array}$ & $\begin{array}{c}\text { Bromide } \\
\text { (mg/L) }\end{array}$ & $\begin{array}{l}\text { Silica } \\
\text { (mg/L) }\end{array}$ \\
\hline Point of Rocks Spring & 13 & Ash Meadows & 49 & 21 & 69 & 7.7 & 21 & 80 & 1.4 & - & 23 \\
\hline Tule Spring & 14 & California Valley & 56 & 32 & 73 & 11 & 35 & 130 & 1.7 & $<0.010$ & 40 \\
\hline Twelvemile Spring & 15 & Chicago Valley & 43 & 24 & 76 & 11 & 46 & 100 & 1.6 & 0.086 & 24 \\
\hline Resting Spring & 16 & Chicago Valley & 24 & 25 & 110 & 21 & 54 & 120 & 2.1 & - & 65 \\
\hline Salsberry Spring & 17 & Greenwater Range & 6.9 & 1.0 & 63 & 1.3 & 14 & 16 & 0.47 & 0.016 & 36 \\
\hline Crystal Spring & 18 & Kingston Range & 13 & 23 & 60 & 2.6 & 65 & 230 & 2.5 & 0.240 & 68 \\
\hline Nevada National Security Site well & 19 & $\begin{array}{c}\text { Nevada National } \\
\text { Security Site }\end{array}$ & 33 & 12 & 55 & 8.9 & 13 & 33 & 0.75 & 0.68 & 29 \\
\hline 162 S20 E 5323 ABAD1 U19 & 20 & Pahrump Valley & 45 & 23 & 4.2 & 1.1 & 2.6 & 24 & 0.16 & - & 11 \\
\hline Hidden Hills Ranch well & 21 & Pahrump Valley & 56 & 26 & 13 & 1.7 & 3.0 & 56 & 0.40 & - & 51 \\
\hline Jeep Trail well & 22 & Pahrump Valley & 36 & 20 & 7.8 & 1.1 & 2.4 & 44 & 0.14 & - & 20 \\
\hline NC-GWE-PV-04 & 23 & Pahrump Valley & 23 & 36 & 11 & 2.0 & 2.8 & 26 & 0.62 & 0.04 & 35 \\
\hline Stump Spring well & 24 & Pahrump Valley & 30 & 19 & 10 & 1.9 & 0.98 & 36 & 0.27 & 0.011 & 24 \\
\hline Black Mountain precipitation & 25 & Precipitation & - & - & - & - & - & - & - & - & - \\
\hline Kingston Range precipitation & 26 & Precipitation & - & - & - & - & - & - & - & - & - \\
\hline Mt. Charleston precipitation & 27 & Precipitation & - & - & - & - & - & - & - & - & - \\
\hline Nopah Range precipitation & 28 & Precipitation & - & - & - & - & - & - & - & - & - \\
\hline Borax Spring & 29 & Shoshone-Tecopa & 0.30 & 0.10 & 690 & 12 & 98 & 200 & 9.4 & - & 95 \\
\hline Chappo Spring & 30 & Shoshone-Tecopa & 36 & 23 & 85 & 15 & 46 & 100 & 1.9 & - & 34 \\
\hline Cynthia's well & 31 & Shoshone-Tecopa & 20 & 21 & 210 & 17 & 46 & 220 & 2.7 & - & 67 \\
\hline Shoshone Spring & 32 & Shoshone-Tecopa & 43 & 24 & 220 & 28 & 140 & 230 & 2.2 & - & 40 \\
\hline Thom Spring & 33 & Shoshone-Tecopa & 23 & 18 & 290 & 31 & 100 & 240 & 2.4 & - & 81 \\
\hline Wild Bath Spring & 34 & Shoshone-Tecopa & 20 & 11 & 300 & 29 & 100 & 240 & 2.2 & - & 96 \\
\hline Horse Springs & 35 & Spring Mountains & 61 & 30 & 6.0 & 0.90 & 5.4 & 9.6 & - & 0.11 & 12 \\
\hline Lost Cabin Spring & 36 & Spring Mountains & 65 & 32 & 18 & 1.5 & 12 & 120 & 0.28 & 0.14 & 20 \\
\hline Peak Spring & 37 & Spring Mountains & 31 & 7.2 & 0.79 & 0.25 & 0.45 & 2.4 & 0.050 & 0.020 & 4.1 \\
\hline Rainbow Spring & 38 & Spring Mountains & 58 & 41 & 5.8 & 1.4 & 5.3 & 12 & 0.13 & - & 12 \\
\hline Borehole Spring & 39 & Tecopa Hot Springs & 3.8 & 0.96 & 760 & 27 & 530 & 570 & 3.9 & - & 91 \\
\hline Tecopa Hot Springs & 40 & Tecopa Hot Springs & 2.3 & 0.34 & 850 & 29 & 570 & 610 & 4.0 & - & 84 \\
\hline
\end{tabular}


Table 10. Selected chemistry of representative samples used in geochemical analysis and modeling, Lower Amargosa Valley and extra-basin contributing areas, California and Nevada.-Continued

[B, boron; Ca, calcium; $\mathrm{Cl}$, chloride; $\mathrm{HCO}$, bicarbonate, $\mathrm{Mg}$, magnesium; mg/L, milligram per liter; Na, sodium; NAD83, North American Datum of 1983; pMC, percent modern carbon; SO , sulfate; Sr, strontium; TU, tritium unit; UTM, Universal Transverse Mercator; $\mu \mathrm{g} / \mathrm{L}$, microgram per liter; $\mu \mathrm{S} / \mathrm{cm}$, microsiemens per centimeter; \%o, per mil; ${ }^{\circ} \mathrm{C}$, degrees Celsius; $<$, less than; - , no data available]

\begin{tabular}{|c|c|c|c|c|c|c|c|c|c|c|}
\hline Site name & $\begin{array}{c}\text { Site } \\
\text { reference } \\
\text { number }\end{array}$ & Group & $\begin{array}{l}\text { Aluminum } \\
(\mu \mathrm{g} / \mathrm{L})\end{array}$ & $\begin{array}{c}\text { Antimony } \\
(\mu \mathrm{g} / \mathrm{L})\end{array}$ & $\begin{array}{c}\text { Arsenic } \\
\text { ( } \mu \mathrm{g} / \mathrm{L})\end{array}$ & $\begin{array}{l}\text { Barium } \\
(\mu \mathrm{g} / \mathrm{L})\end{array}$ & $\begin{array}{l}\text { Beryllium } \\
(\mu \mathrm{g} / \mathrm{L})\end{array}$ & $\begin{array}{l}\text { Boron } \\
(\mu \mathrm{g} / \mathrm{L})\end{array}$ & $\begin{array}{l}\text { Cadmium } \\
(\mu \mathrm{g} / \mathrm{L})\end{array}$ & $\begin{array}{l}\text { Chromium } \\
(\mu \mathrm{g} / \mathrm{L})\end{array}$ \\
\hline Amargosa Canyon Spring 1 & 1 & Amargosa Canyon & - & - & 20 & - & - & 1,900 & - & - \\
\hline Amargosa Canyon Spring 4 & 2 & Amargosa Canyon & - & - & - & - & - & 1,200 & - & - \\
\hline Willow Spring & 3 & Amargosa Canyon & - & - & - & - & - & 1,000 & - & - \\
\hline Amargosa River (AR3314; Seepage Run) & 4 & Amargosa River & $<22$ & 1.3 & 1,000 & 28 & 3.2 & - & 0.31 & $<3.0$ \\
\hline Amargosa River 2 & 5 & Amargosa River & - & - & 150 & - & - & 9,500 & - & - \\
\hline Amargosa River at Tecopa, CA & 6 & Amargosa River & 110 & 1.0 & 750 & 23 & 1.6 & 20,000 & $<0.30$ & $<3.0$ \\
\hline Amargosa River in Upper Canyon near Tecopa, CA & 7 & Amargosa River & 1.8 & 0.55 & 170 & - & $<0.12$ & 7,900 & 0.08 & 0.50 \\
\hline Crystal Pool & 8 & Ash Meadows & 3.3 & $<1.0$ & 15 & 67 & $<1.0$ & 380 & $<1.0$ & 3.0 \\
\hline Devils Hole (AM-4) & 9 & Ash Meadows & 1.7 & 0.17 & 12 & 76 & $<0.060$ & 360 & 0.05 & 0.18 \\
\hline Fairbanks Spring & 10 & Ash Meadows & 3.9 & - & 10 & 80 & $<1.0$ & 360 & - & 2.0 \\
\hline Five Springs well (AM-2) & 11 & Ash Meadows & 100 & - & 16 & 64 & 1.00 & 150 & $<10$ & $<1.0$ \\
\hline Hog Farm well & 12 & Ash Meadows & $<500$ & $<10$ & 120 & $<3.0$ & $<3.0$ & 1,800 & $<3.0$ & $<3.0$ \\
\hline Point of Rocks Spring & 13 & Ash Meadows & - & - & - & - & - & 280 & - & - \\
\hline Tule Spring & 14 & California Valley & 3.8 & 0.27 & 21 & 49 & 0.035 & - & $<0.016$ & $<0.07$ \\
\hline Twelvemile Spring & 15 & Chicago Valley & 3.6 & 0.18 & 32 & 41 & 0.071 & 1,400 & $<0.016$ & 0.10 \\
\hline Resting Spring & 16 & Chicago Valley & - & - & 59 & - & - & - & - & - \\
\hline Salsberry Spring & 17 & Greenwater Range & 900 & 0.49 & 4.5 & 3.0 & 0.33 & - & 0.047 & 0.35 \\
\hline Crystal Spring & 18 & Kingston Range & 10 & - & 7.0 & 79 & 0.50 & 610 & 1.0 & 5.0 \\
\hline Nevada National Security Site well & 19 & $\begin{array}{c}\text { Nevada National } \\
\text { Security Site }\end{array}$ & - & - & - & - & - & - & - & - \\
\hline 162 S20 E 5323 ABAD1 U19 & 20 & Pahrump Valley & $<2.2$ & $<0.027$ & 0.50 & 52 & $<0.020$ & 28 & $<0.030$ & 0.56 \\
\hline Hidden Hills Ranch well & 21 & Pahrump Valley & - & - & - & - & - & - & - & - \\
\hline Jeep Trail well & 22 & Pahrump Valley & - & - & 8.0 & - & - & - & - & - \\
\hline NC-GWE-PV-04 & 23 & Pahrump Valley & $<2.2$ & 0.092 & 2.6 & 83 & $<0.006$ & - & $<0.016$ & 3.0 \\
\hline Stump Spring well & 24 & Pahrump Valley & 3.9 & 0.067 & 1.7 & 68 & $<0.020$ & 32 & 0.050 & 4.7 \\
\hline Black Mountain Precipitation & 25 & Precipitation & - & - & - & - & - & - & - & - \\
\hline Kingston Range Precipitation & 26 & Precipitation & - & - & - & - & - & - & - & - \\
\hline Mt. Charleston Precipitation & 27 & Precipitation & - & - & - & - & - & - & - & - \\
\hline Nopah Range Precipitation & 28 & Precipitation & - & - & - & - & - & - & - & - \\
\hline
\end{tabular}


Table 10. Selected chemistry of representative samples used in geochemical analysis and modeling, Lower Amargosa Valley and extra-basin contributing areas, California and Nevada.-Continued

[B, boron; Ca, calcium; $\mathrm{Cl}$, chloride; $\mathrm{HCO}_{3}$, bicarbonate, $\mathrm{Mg}$, magnesium; mg/L, milligram per liter; Na, sodium; NAD83, North American Datum of 1983; pMC, percent modern carbon; $\mathrm{SO}$, sulfate; Sr, strontium; TU, tritium unit; UTM, Universal Transverse Mercator; $\mu \mathrm{g} / \mathrm{L}$, microgram per liter; $\mu \mathrm{S} / \mathrm{cm}$, microsiemens per centimeter; \%, per mil; ${ }^{\circ} \mathrm{C}$, degrees Celsius; <, less than; - , no data available]

\begin{tabular}{|c|c|c|c|c|c|c|c|c|c|c|c|}
\hline Site name & $\begin{array}{c}\text { Site } \\
\text { reference } \\
\text { number }\end{array}$ & Group & $\begin{array}{c}\text { Aluminum } \\
\text { ( } \mu \mathrm{g} / \mathrm{L})\end{array}$ & \multicolumn{2}{|c|}{$\begin{array}{c}\text { Antimony } \\
(\mu \mathrm{g} / \mathrm{L})\end{array}$} & $\begin{array}{c}\text { Arsenic } \\
\text { ( } \mu \mathrm{g} / \mathrm{L})\end{array}$ & $\begin{array}{c}\text { Barium } \\
\text { ( } \mu \mathrm{g} / \mathrm{L})\end{array}$ & $\begin{array}{l}\text { Beryllium } \\
\text { ( } \mu \mathrm{g} / \mathrm{L})\end{array}$ & $\begin{array}{l}\text { Boron } \\
(\mu \mathrm{g} / \mathrm{L})\end{array}$ & $\begin{array}{l}\text { Cadmium } \\
\text { ( } \mu \mathrm{g} / \mathrm{L})\end{array}$ & $\begin{array}{c}\text { Chromium } \\
\text { ( } \mu \mathrm{g} / \mathrm{L})\end{array}$ \\
\hline Borax Spring & 29 & Shoshone-Tecopa & - & \multicolumn{2}{|c|}{-} & 1,600 & - & - & 130,000 & - & - \\
\hline Chappo Spring & 30 & Shoshone-Tecopa & - & \multicolumn{2}{|c|}{ - } & 79 & - & - & 2,000 & - & - \\
\hline Cynthia's well & 31 & Shoshone-Tecopa & $<500$ & \multicolumn{2}{|l|}{$<10$} & 13 & 20 & $<3.0$ & 1,400 & $<3.0$ & $<3.0$ \\
\hline Shoshone Spring & 32 & Shoshone-Tecopa & - & \multicolumn{2}{|c|}{ - } & 71 & - & - & 4,200 & - & - \\
\hline Thom Spring & 33 & Shoshone-Tecopa & - & \multicolumn{2}{|c|}{ - } & 88 & - & - & 5,300 & - & - \\
\hline Wild Bath Spring & 34 & Shoshone-Tecopa & - & \multicolumn{2}{|c|}{ - } & 110 & - & - & 6,500 & - & 一 \\
\hline Horse Springs & 35 & Spring Mountains & - & \multicolumn{2}{|c|}{ - } & - & - & - & - & - & - \\
\hline Lost Cabin Spring & 36 & Spring Mountains & 3.0 & \multicolumn{2}{|c|}{0.049} & 0.85 & 29 & $<0.012$ & 110 & $<0.020$ & 0.080 \\
\hline Peak Spring & 37 & Spring Mountains & 2.40 & \multicolumn{2}{|c|}{$<0.014$} & 0.2 & 11 & $<0.008$ & 8.6 & $<0.040$ & 0.44 \\
\hline Rainbow Spring & 38 & Spring Mountains & - & \multicolumn{2}{|c|}{ - } & - & - & - & - & - & - \\
\hline Borehole Spring & 39 & Tecopa Hot Springs & - & \multicolumn{2}{|c|}{ - } & 330 & - & - & 9,200 & - & - \\
\hline \multirow{2}{*}{ Tecopa Hot Springs } & 40 & Tecopa Hot Springs & - & \multicolumn{2}{|c|}{ - } & 310 & 30 & - & 11,000 & - & - \\
\hline & $\begin{array}{c}\text { Site } \\
\text { reference } \\
\text { number }\end{array}$ & Group & $\begin{array}{l}\text { Cobalt } \\
(\mu \mathrm{g} / \mathrm{L})\end{array}$ & $\begin{array}{c}\text { Copper } \\
(\mu \mathrm{g} / \mathrm{L})\end{array}$ & $\begin{array}{l}\text { Iron } \\
(\mu \mathrm{g} / \mathrm{L})\end{array}$ & $\begin{array}{c}\text { Lead } \\
\text { ( } \mu \mathrm{g} / \mathrm{L})\end{array}$ & $\begin{array}{l}\text { Lithium } \\
\text { ( } \mu \mathrm{g} / \mathrm{L} \text { ) }\end{array}$ & $\begin{array}{c}\text { Manganese } \\
\text { ( } \mu \mathrm{g} / \mathrm{L})\end{array}$ & $\begin{array}{c}\text { Molybdenum } \\
(\mu \mathrm{g} / \mathrm{L})\end{array}$ & $\begin{array}{c}\text { Nickel } \\
(\mu \mathrm{g} / \mathrm{L})\end{array}$ & $\begin{array}{c}\text { Selenium } \\
\text { ( } \mu \mathrm{g} / \mathrm{L})\end{array}$ \\
\hline Amargosa Canyon Spring 1 & 1 & Amargosa Canyon & - & - & - & - & - & - & - & - & - \\
\hline Amargosa Canyon Spring 4 & 2 & Amargosa Canyon & - & - & - & - & - & - & - & - & - \\
\hline Willow Spring & 3 & Amargosa Canyon & - & - & - & - & - & - & - & - & - \\
\hline Amargosa River (AR3314; Seepage Run) & 4 & Amargosa River & $<0.50$ & $<8.0$ & $<28.0$ & $<0.40$ & - & 5.5 & 120 & $<2$ & 1.20 \\
\hline Amargosa River 2 & 5 & Amargosa River & - & - & - & - & - & - & - & - & - \\
\hline Amargosa River at Tecopa, CA & 6 & Amargosa River & 0.61 & $<8.0$ & 110 & $<0.40$ & - & 8.3 & 64 & $<2.0$ & $<0.50$ \\
\hline Amargosa River in Upper Canyon near Tecopa, CA & 7 & Amargosa River & 0.20 & 2.8 & 21 & 0.22 & - & 86 & 41 & 1.0 & 1.0 \\
\hline Crystal Pool & 8 & Ash Meadows & $<1.0$ & $<1.0$ & 14 & $<1.0$ & 90 & $<1.0$ & 7.8 & $<1.0$ & $<1.0$ \\
\hline Devils Hole (AM-4) & 9 & Ash Meadows & 0.067 & 1.3 & 5.3 & 0.05 & 80 & 0.33 & 6.4 & 0.93 & 0.86 \\
\hline Fairbanks Spring & 10 & Ash Meadows & $<1.0$ & 1.0 & 12 & - & 90 & $<1.0$ & 7.40 & $<1.0$ & $<1.0$ \\
\hline Five Springs well (AM-2) & 11 & Ash Meadows & 1.0 & $<10$ & 10 & $<100$ & 84 & 1.00 & 5.6 & 1.4 & $<1.0$ \\
\hline Hog Farm well & 12 & Ash Meadows & $<3.0$ & $<5.0$ & $<100$ & $<5.0$ & $<100$ & $<500$ & 14 & $<5.0$ & $<10$ \\
\hline Point of Rocks Spring & 13 & Ash Meadows & - & - & - & - & 88 & - & - & - & - \\
\hline Tule Spring & 14 & California Valley & 0.97 & $<0.80$ & 21 & 0.056 & - & 30.9 & 4.5 & 0.47 & 0.12 \\
\hline
\end{tabular}


Table 10. Selected chemistry of representative samples used in geochemical analysis and modeling, Lower Amargosa Valley and extra-basin contributing areas, California and Nevada.-Continued

[B, boron; Ca, calcium; $\mathrm{Cl}$, chloride; $\mathrm{HCO}$, bicarbonate, $\mathrm{Mg}$, magnesium; mg/L, milligram per liter; Na, sodium; NAD83, North American Datum of 1983; pMC, percent modern carbon; SO , sulfate; Sr, strontium; TU, tritium unit; UTM, Universal Transverse Mercator; $\mu \mathrm{g} / \mathrm{L}$, microgram per liter; $\mu \mathrm{S} / \mathrm{cm}$, microsiemens per centimeter; \%o, per mil; ${ }^{\circ} \mathrm{C}$, degrees Celsius; $<$, less than; - , no data available]

\begin{tabular}{|c|c|c|c|c|c|c|c|c|c|c|c|}
\hline Site name & $\begin{array}{c}\text { Site } \\
\text { reference } \\
\text { number }\end{array}$ & Group & $\begin{array}{l}\text { Cobalt } \\
(\mu \mathrm{g} / \mathrm{L})\end{array}$ & $\begin{array}{l}\text { Copper } \\
\text { ( } \mu \mathrm{g} / \mathrm{L})\end{array}$ & $\begin{array}{l}\text { Iron } \\
(\mu g / L)\end{array}$ & $\begin{array}{l}\text { Lead } \\
(\mu \mathrm{g} / \mathrm{L})\end{array}$ & $\begin{array}{l}\text { Lithium } \\
\text { ( } \mu \mathrm{g} / \mathrm{L})\end{array}$ & $\begin{array}{l}\text { Manganese } \\
(\mu \mathrm{g} / \mathrm{L})\end{array}$ & $\begin{array}{l}\text { Molybdenum } \\
\text { ( } \mu \mathrm{g} / \mathrm{L})\end{array}$ & $\begin{array}{c}\text { Nickel } \\
\text { ( } \mu \mathrm{g} / \mathrm{L})\end{array}$ & $\begin{array}{l}\text { Selenium } \\
\text { ( } \mu \mathrm{g} / \mathrm{L})\end{array}$ \\
\hline Twelvemile Spring & 15 & Chicago Valley & 0.042 & $<0.80$ & $<4.0$ & 0.031 & 130 & 1.12 & 5.6 & 0.29 & 0.12 \\
\hline Resting Spring & 16 & Chicago Valley & - & - & 180 & - & - & - & - & - & - \\
\hline Salsberry Spring & 17 & Greenwater Range & 2.9 & 3.1 & 470 & 1.5 & - & 15 & 1.3 & 1.2 & 0.30 \\
\hline Crystal Spring & 18 & Kingston Range & 3.0 & 10 & 7.0 & 10 & 70 & 330 & 10 & 20 & - \\
\hline Nevada National Security Site well & 19 & $\begin{array}{c}\text { Nevada National } \\
\text { Security Site }\end{array}$ & - & - & - & - & - & - & - & - & - \\
\hline 162 S20 E 5323 ABAD1 U19 & 20 & Pahrump Valley & $<0.050$ & 1.1 & $<4.0$ & 0.13 & 4.9 & $<0.40$ & 0.50 & 0.38 & 0.56 \\
\hline Hidden Hills Ranch well & 21 & Pahrump Valley & - & - & 10 & - & - & - & - & - & - \\
\hline Jeep Trail well & 22 & Pahrump Valley & - & - & - & - & - & - & - & - & - \\
\hline NC-GWE-PV-04 & 23 & Pahrump Valley & 0.038 & $<0.80$ & $<4.0$ & $<0.025$ & - & 0.19 & 4.5 & 0.17 & 0.67 \\
\hline Stump Spring well & 24 & Pahrump Valley & $<1.4$ & 1.3 & 2.2 & 0.13 & - & 1.3 & 2.7 & 0.71 & 0.71 \\
\hline Black Mountain Precipitation & 25 & Precipitation & - & - & - & - & - & - & - & - & - \\
\hline Kingston Range Precipitation & 26 & Precipitation & - & - & - & - & - & - & - & - & - \\
\hline Mt. Charleston Precipitation & 27 & Precipitation & - & - & - & - & - & - & - & - & - \\
\hline Nopah Range Precipitation & 28 & Precipitation & - & - & - & - & - & - & - & - & - \\
\hline Borax Spring & 29 & Shoshone-Tecopa & - & - & - & - & - & - & - & - & - \\
\hline Chappo Spring & 30 & Shoshone-Tecopa & - & - & - & - & - & - & - & - & - \\
\hline Cynthia's well & 31 & Shoshone-Tecopa & $<3.0$ & $<5.0$ & 320 & $<5.0$ & - & $<500$ & 13 & $<5.0$ & $<10$ \\
\hline Shoshone Spring & 32 & Shoshone-Tecopa & - & - & - & - & - & - & - & - & - \\
\hline Thom Spring & 33 & Shoshone-Tecopa & - & - & 290 & - & - & - & - & - & - \\
\hline Wild Bath Spring & 34 & Shoshone-Tecopa & - & - & - & - & - & - & - & - & - \\
\hline Horse Springs & 35 & Spring Mountains & - & - & - & - & - & - & - & - & - \\
\hline Lost Cabin Spring & 36 & Spring Mountains & 0.12 & $<1.0$ & 9.9 & 0.015 & 19 & 2.4 & 1.4 & 0.87 & 1.6 \\
\hline Peak Spring & 37 & Spring Mountains & $<1.4$ & $<1.0$ & $<6.0$ & $<0.080$ & - & $<0.20$ & 0.66 & 0.21 & 0.44 \\
\hline Rainbow Spring & 38 & Spring Mountains & - & - & - & - & - & - & - & - & - \\
\hline Borehole Spring & 39 & Tecopa Hot Springs & - & - & 320 & - & - & - & - & - & - \\
\hline Tecopa Hot Springs & 40 & Tecopa Hot Springs & - & - & - & - & 220 & - & - & - & - \\
\hline
\end{tabular}


Table 10. Selected chemistry of representative samples used in geochemical analysis and modeling, Lower Amargosa Valley and extra-basin contributing areas, California and Nevada.-Continued

[B, boron; Ca, calcium; $\mathrm{Cl}$, chloride; $\mathrm{HCO}_{3}$, bicarbonate, $\mathrm{Mg}$, magnesium; mg/L, milligram per liter; Na, sodium; NAD83, North American Datum of 1983; pMC, percent modern carbon; $\mathrm{SO}$, sulfate; Sr, strontium; TU, tritium unit; UTM, Universal Transverse Mercator; $\mu \mathrm{g} / \mathrm{L}$, microgram per liter; $\mu \mathrm{S} / \mathrm{cm}$, microsiemens per centimeter; $\%$, per mil; ${ }^{\circ} \mathrm{C}$, degrees Celsius; $<$, less than; - , no data available]

\begin{tabular}{|c|c|c|c|c|c|c|c|c|c|c|c|}
\hline Site name & $\begin{array}{c}\text { Site } \\
\text { reference } \\
\text { number }\end{array}$ & Group & $\begin{array}{l}\text { Strontium } \\
(\mu \mathrm{g} / \mathrm{L})\end{array}$ & $\begin{array}{c}\text { Uranium } \\
\text { ( } \mu \mathrm{g} / \mathrm{L})\end{array}$ & $\begin{array}{l}\text { Zinc } \\
(\mu g / L)\end{array}$ & $\begin{array}{l}\text { Nitrate + nitrite } \\
\text { as nitrate } \\
(\mathrm{mg} / \mathrm{L})\end{array}$ & $\begin{array}{l}\mathrm{Sr} / \mathrm{Ca} \\
\text { ratio }\end{array}$ & $\begin{array}{c}\mathrm{Na} / \mathrm{Ca} \\
\text { ratio }\end{array}$ & $\begin{array}{l}\text { Tritium } \\
\text { (TU) }\end{array}$ & $\begin{array}{l}\delta^{2} \mathbf{H} \\
(\%)\end{array}$ & $\begin{array}{l}\delta^{18} 0 \\
(\% 0)\end{array}$ \\
\hline Amargosa Canyon Spring 1 & 1 & Amargosa Canyon & 1,200 & 2.4 & - & - & 0.029 & 3.4 & 1.10 & -94.0 & -12.9 \\
\hline Amargosa Canyon Spring 4 & 2 & Amargosa Canyon & 1,100 & 8.4 & - & - & 0.028 & 5.1 & 0.70 & -95.0 & -13.1 \\
\hline Willow Spring & 3 & Amargosa Canyon & 1,500 & 6.4 & - & 0.1 & 0.023 & 1.7 & $<0.8$ & -95.0 & -12.8 \\
\hline Amargosa River (AR3314; Seepage Run) & 4 & Amargosa River & 2,700 & 16 & $<20$ & - & 0.17 & 190 & - & -81.1 & -9.20 \\
\hline Amargosa River 2 & 5 & Amargosa River & 3,800 & 18 & - & - & 0.066 & 14 & 0.70 & -89.0 & -11.3 \\
\hline Amargosa River at Tecopa, CA & 6 & Amargosa River & 700 & 14 & $<20$ & 0.87 & 0.059 & 180 & 2.8 & -81.5 & -9.10 \\
\hline Amargosa River in Upper Canyon near Tecopa, CA & 7 & Amargosa River & - & - & 2.2 & 0.37 & - & 14 & 1.12 & -91.9 & -12.0 \\
\hline Crystal Pool & 8 & Ash Meadows & 930 & 3.2 & $<1.0$ & 0.34 & 0.020 & 1.6 & $<0.3$ & -103 & -13.7 \\
\hline Devils Hole (AM-4) & 9 & Ash Meadows & 880 & 3.2 & 0.90 & 0.59 & 0.017 & 1.3 & $<0.30$ & -103 & -13.4 \\
\hline Fairbanks Spring & 10 & Ash Meadows & 850 & 2.7 & $<1.0$ & 0.04 & 0.017 & 1.4 & $<0.30$ & -103 & -13.8 \\
\hline Five Springs well (AM-2) & 11 & Ash Meadows & 860 & 2.0 & 8.00 & 0.22 & 0.017 & 1.3 & $<1.2$ & -104 & -14.1 \\
\hline Hog Farm well & 12 & Ash Meadows & 150 & - & $<10$ & - & 0.094 & 190 & - & - & - \\
\hline Point of Rocks Spring & 13 & Ash Meadows & 830 & 3.1 & - & - & 0.017 & 1.41 & - & -104 & -13.6 \\
\hline Tule Spring & 14 & California Valley & 1,700 & 1.3 & $<1.4$ & - & 0.030 & 1.30 & $<5.0$ & -93.8 & -12.6 \\
\hline Twelvemile Spring & 15 & Chicago Valley & 1,000 & 1.0 & $<1.4$ & 0.19 & 0.023 & 1.8 & 0.10 & - & - \\
\hline Resting Spring & 16 & Chicago Valley & 980 & 2.4 & - & - & 0.041 & 4.58 & $<1$ & -96.0 & -13.2 \\
\hline Salsberry Spring & 17 & Greenwater Range & 62 & 1.3 & 9.0 & - & 0.0090 & 9.2 & 14.0 & -87.4 & -11.2 \\
\hline Crystal Spring & 18 & Kingston Range & 690 & 1.3 & 12 & - & 0.0531 & 4.62 & 2.3 & -105.0 & -13.8 \\
\hline Nevada National Security Site well & 19 & $\begin{array}{c}\text { Nevada National } \\
\text { Security Site }\end{array}$ & 200 & 3.1 & - & - & 0.0061 & 1.7 & - & -108 & -14.0 \\
\hline 162 S20 E 5323 ABAD1 U19 & 20 & Pahrump Valley & 340 & 1.4 & 2.2 & 0.41 & 0.0076 & 0.09 & - & -99.7 & -13.5 \\
\hline Hidden Hills Ranch well & 21 & Pahrump Valley & 1,000 & - & - & - & 0.018 & 0.24 & $<5$ & -98.0 & -13.7 \\
\hline Jeep Trail well & 22 & Pahrump Valley & 1,500 & - & - & 0.24 & 0.042 & 0.22 & 0.30 & -101 & -13.6 \\
\hline NC-GWE-PV-04 & 23 & Pahrump Valley & 570 & 2.3 & 3.0 & 0.33 & 0.025 & 0.47 & - & -97.8 & -13.4 \\
\hline Stump Spring well & 24 & Pahrump Valley & 1,200 & 1.3 & 3.3 & 0.17 & 0.040 & 0.34 & 0.50 & -107 & -14.6 \\
\hline Black Mountain Precipitation & 25 & Precipitation & - & - & - & - & - & - & - & -106 & -13.9 \\
\hline Kingston Range Precipitation & 26 & Precipitation & - & - & - & - & - & - & - & -61.0 & -7.43 \\
\hline Mt. Charleston Precipitation & 27 & Precipitation & - & - & - & - & - & - & - & -81.2 & -11.7 \\
\hline Nopah Range Precipitation & 28 & Precipitation & - & - & - & - & - & - & - & -78.4 & -9.19 \\
\hline
\end{tabular}


Table 10. Selected chemistry of representative samples used in geochemical analysis and modeling, Lower Amargosa Valley and extra-basin contributing areas, California and Nevada.-Continued

[B, boron; Ca, calcium; $\mathrm{Cl}$, chloride; $\mathrm{HCO}$, bicarbonate, $\mathrm{Mg}$, magnesium; mg/L, milligram per liter; Na, sodium; NAD83, North American Datum of 1983; pMC, percent modern carbon; SO , sulfate; Sr, strontium; TU, tritium unit; UTM, Universal Transverse Mercator; $\mu \mathrm{g} / \mathrm{L}$, microgram per liter; $\mu \mathrm{S} / \mathrm{cm}$, microsiemens per centimeter; \%o, per mil; ${ }^{\circ} \mathrm{C}$, degrees Celsius; $<$, less than; - , no data available]

\begin{tabular}{|c|c|c|c|c|c|c|c|c|c|c|c|}
\hline Site name & $\begin{array}{c}\text { Site } \\
\text { reference } \\
\text { number }\end{array}$ & Group & $\begin{array}{l}\text { Strontium } \\
(\mu \mathrm{g} / \mathrm{L})\end{array}$ & $\begin{array}{l}\text { Uranium } \\
\text { ( } \mu \mathrm{g} / \mathrm{L})\end{array}$ & $\begin{array}{l}\text { Zinc } \\
(\mu g / L)\end{array}$ & $\begin{array}{l}\text { Nitrate }+ \text { nitrite } \\
\text { as nitrate } \\
(\mathrm{mg} / \mathrm{L})\end{array}$ & $\begin{array}{l}\mathrm{Sr} / \mathrm{Ca} \\
\text { ratio }\end{array}$ & $\begin{array}{c}\mathrm{Na} / \mathrm{Ca} \\
\text { ratio }\end{array}$ & $\begin{array}{l}\text { Tritium } \\
\text { (TU) }\end{array}$ & $\begin{array}{l}\delta^{2} \mathbf{H} \\
(\%)\end{array}$ & $\begin{array}{l}\delta^{18} 0 \\
(\%)\end{array}$ \\
\hline Borax Spring & 29 & Shoshone-Tecopa & 44 & 1.2 & - & - & 0.15 & 2,300 & $<0.9$ & -100 & -13.3 \\
\hline Chappo Spring & 30 & Shoshone-Tecopa & 920 & 1.8 & - & - & 0.026 & 2.36 & $<1$ & -94.0 & -13.0 \\
\hline Cynthia's well & 31 & Shoshone-Tecopa & 930 & 5.7 & $<10$ & - & 0.047 & 10.50 & 1.20 & -93.0 & -12.2 \\
\hline Shoshone Spring & 32 & Shoshone-Tecopa & 1,100 & 3.8 & - & 1.4 & 0.026 & 5.12 & $<0.6$ & -93.0 & -12.6 \\
\hline Thom Spring & 33 & Shoshone-Tecopa & 680 & 4.5 & - & - & 0.030 & 12.61 & $<0.9$ & -95.0 & -13.1 \\
\hline Wild Bath Spring & 34 & Shoshone-Tecopa & 490 & 2.9 & - & - & 0.025 & 15.00 & $<0.6$ & -95.0 & -13.1 \\
\hline Horse Springs & 35 & Spring Mountains & 170 & 1.4 & - & 0.61 & 0.003 & 0.10 & 0.7 & -99.6 & -13.4 \\
\hline Lost Cabin Spring & 36 & Spring Mountains & 4,700 & 2.1 & $<2.8$ & 1.4 & 0.072 & 0.28 & 7.0 & -88.5 & -11.9 \\
\hline Peak Spring & 37 & Spring Mountains & 93 & 0.64 & $<1.8$ & 0.24 & 0.0030 & 0.03 & 15 & -86.4 & -12.5 \\
\hline Rainbow Spring & 38 & Spring Mountains & 130 & 1.84 & - & 3.19 & 0.002 & 0.10 & $<5.0$ & -94.0 & -12.9 \\
\hline Borehole Spring & 39 & Tecopa Hot Springs & 93 & 6.6 & - & - & 0.024 & 200.0 & $<1.1$ & -95.0 & -12.9 \\
\hline Tecopa Hot Springs & 40 & Tecopa Hot Springs & 90 & 7.1 & - & 0.07 & 0.039 & 369.57 & $<0.5$ & -98.0 & -12.7 \\
\hline \multirow[b]{2}{*}{ Site name } & \multirow{2}{*}{$\begin{array}{c}\text { Site } \\
\text { reference } \\
\text { number }\end{array}$} & \multirow[b]{2}{*}{ Group } & \multirow[b]{2}{*}{$\begin{array}{c}\text { C14 } \\
\text { (pMC) }\end{array}$} & \multirow[b]{2}{*}{$\begin{array}{l}\delta^{13} \mathrm{C} \\
(\%)\end{array}$} & \multicolumn{3}{|c|}{ Decimal longitude Decimal latitude } & \multicolumn{2}{|c|}{ UTM Easting } & UTM N & lorthing \\
\hline & & & & & \multicolumn{3}{|c|}{ (assumed to be NAD83) } & \multicolumn{4}{|c|}{$\begin{array}{c}\text { Zone } 11 \text { NAD83 } \\
\text { (in meters) }\end{array}$} \\
\hline Amargosa Canyon Spring 1 & 1 & Amargosa Canyon & - & - & \multicolumn{2}{|c|}{-116.22399} & 35.83937 & \multicolumn{2}{|c|}{570083} & \multicolumn{2}{|c|}{3966410} \\
\hline Amargosa Canyon Spring 4 & 2 & Amargosa Canyon & - & - & \multicolumn{2}{|c|}{-116.22260} & 35.83480 & \multicolumn{2}{|c|}{570212} & \multicolumn{2}{|c|}{3965905} \\
\hline Willow Spring & 3 & Amargosa Canyon & - & - & \multicolumn{2}{|c|}{-116.18284} & 35.80556 & \multicolumn{2}{|c|}{573831} & \multicolumn{2}{|c|}{3962691} \\
\hline Amargosa River (AR3314; Seepage Run) & 4 & Amargosa River & - & - & \multicolumn{2}{|c|}{-116.25901} & 35.90759 & \multicolumn{2}{|c|}{566863} & \multicolumn{2}{|c|}{3973952} \\
\hline Amargosa River 2 & 5 & Amargosa River & - & - & \multicolumn{2}{|c|}{-116.22219} & 35.74637 & \multicolumn{2}{|c|}{570327} & \multicolumn{2}{|c|}{3956097} \\
\hline Amargosa River at Tecopa, CA & 6 & Amargosa River & - & - & \multicolumn{2}{|c|}{-116.22912} & 35.84861 & \multicolumn{2}{|c|}{569612} & \multicolumn{2}{|c|}{3967432} \\
\hline Amargosa River in Upper Canyon near Tecopa, CA & 7 & Amargosa River & - & - & -11 & 16.22000 & 35.82556 & & 70455 & 3964 & 4881 \\
\hline Crystal Pool & 8 & Ash Meadows & 11.2 & -5.70 & -11 & 16.32417 & 36.42028 & & 60588 & 4030 & 0777 \\
\hline Devils Hole (AM-4) & 9 & Ash Meadows & 2.8 & -6.80 & -11 & 16.29083 & 36.42556 & & 63572 & 4031 & 1384 \\
\hline Fairbanks Spring & 10 & Ash Meadows & 2.8 & -6.80 & -11 & 16.39218 & 36.49049 & & 54441 & 4038 & 8525 \\
\hline Five Springs well (AM-2) & 11 & Ash Meadows & - & - & -11 & 16.31923 & 36.46458 & & 60996 & 4035 & 5694 \\
\hline Hog Farm well & 12 & Ash Meadows & - & - & -11 & 16.37854 & 36.28748 & & 55808 & 4016 & 6014 \\
\hline Point of Rocks Spring & 13 & Ash Meadows & 6.4 & -5.50 & -11 & 16.27250 & 36.39957 & & 65237 & 4028 & 8514 \\
\hline Tule Spring & 14 & California Valley & 33.7 & -7.00 & -11 & 16.05472 & 35.81694 & & 85394 & 3964 & 4058 \\
\hline
\end{tabular}


Table 10. Selected chemistry of representative samples used in geochemical analysis and modeling, Lower Amargosa Valley and extra-basin contributing areas, California and Nevada.-Continued

[B, boron; Ca, calcium; Cl, chloride; $\mathrm{HCO}_{3}$, bicarbonate, $\mathrm{Mg}$, magnesium; mg/L, milligram per liter; Na, sodium; NAD83, North American Datum of 1983; pMC, percent modern carbon; $\mathrm{SO}$, sulfate; Sr, strontium; TU, tritium unit; UTM, Universal Transverse Mercator; $\mu \mathrm{g} / \mathrm{L}$, microgram per liter; $\mu \mathrm{S} / \mathrm{cm}$, microsiemens per centimeter; \%, per mil; ${ }^{\circ} \mathrm{C}$, degrees Celsius; $<$, less than; - , no data available]

\begin{tabular}{|c|c|c|c|c|c|c|c|c|}
\hline \multirow[b]{2}{*}{ Site name } & \multirow{2}{*}{$\begin{array}{l}\text { Site } \\
\text { reference } \\
\text { number }\end{array}$} & \multirow[b]{2}{*}{ Group } & \multirow{2}{*}{$\begin{array}{c}\text { C14 } \\
\text { (pMC) }\end{array}$} & \multirow{2}{*}{$\begin{array}{l}\delta^{13} \mathrm{C} \\
(\%)\end{array}$} & \multicolumn{2}{|c|}{ Decimal longitude Decimal latitude } & \multirow{2}{*}{\multicolumn{2}{|c|}{$\begin{array}{c}\text { UTM Easting UTM Northing } \\
\text { Zone } 11 \text { NAD83 } \\
\text { (in meters) }\end{array}$}} \\
\hline & & & & & \multicolumn{2}{|c|}{ (assumed to be NAD83) } & & \\
\hline Twelvemile Spring & 15 & Chicago Valley & 11.1 & -6.10 & -116.15444 & 36.02167 & 576189 & 3986682 \\
\hline Resting Spring & 16 & Chicago Valley & - & - & -116.15631 & 35.87732 & 576159 & 3970670 \\
\hline Salsberry Spring & 17 & Greenwater Range & 104 & -10.8 & -116.41869 & 35.93014 & 552439 & 3976356 \\
\hline Crystal Spring & 18 & Kingston Range & 88.4 & -13.2 & -115.96168 & 35.79469 & 593826 & 3961674 \\
\hline Nevada National Security Site well & 19 & $\begin{array}{c}\text { Nevada National } \\
\text { Security Site }\end{array}$ & 2.24 & -4.70 & -115.99286 & 36.98263 & 589633 & 4093419 \\
\hline 162 S20 E 5323 ABAD1 U19 & 20 & Pahrump Valley & 28.8 & -7.4 & -115.96667 & 36.20000 & 592898 & 4006627 \\
\hline Hidden Hills Ranch well & 21 & Pahrump Valley & 50.50 & -8.20 & -115.86502 & 36.01414 & 602277 & 3986112 \\
\hline Jeep Trail well & 22 & Pahrump Valley & 40.5 & -8.80 & -115.76802 & 36.00479 & 611032 & 3985181 \\
\hline NC-GWE-PV-04 & 23 & Pahrump Valley & 18.1 & -7.12 & -116.03748 & 36.16445 & 586571 & 4002617 \\
\hline Stump Spring well & 24 & Pahrump Valley & 6.90 & -7.70 & -115.81917 & 35.99472 & 606436 & 3984008 \\
\hline Black Mountain Precipitation & 25 & Precipitation & - & - & -116.46472 & 35.87868 & 548318 & 3970625 \\
\hline Kingston Range Precipitation & 26 & Precipitation & - & - & -115.94329 & 35.78871 & 595495 & 3961029 \\
\hline Mt. Charleston Precipitation & 27 & Precipitation & - & - & -115.66944 & 36.28806 & 619486 & 4016720 \\
\hline Nopah Range Precipitation & 28 & Precipitation & - & - & -116.05798 & 35.88285 & 585029 & 3971365 \\
\hline Borax Spring & 29 & Shoshone-Tecopa & - & - & -116.25806 & 35.88814 & 566965 & 3971796 \\
\hline Chappo Spring & 30 & Shoshone-Tecopa & - & - & -116.18833 & 35.94722 & 573204 & 3978399 \\
\hline Cynthia's well & 31 & Shoshone-Tecopa & - & - & -116.20478 & 35.84610 & 571812 & 3967171 \\
\hline Shoshone Spring & 32 & Shoshone-Tecopa & - & - & -116.27308 & 35.98052 & 565533 & 3982032 \\
\hline Thom Spring & 33 & Shoshone-Tecopa & - & - & -116.22677 & 35.85661 & 569817 & 3968321 \\
\hline Wild Bath Spring & 34 & Shoshone-Tecopa & - & - & -116.21932 & 35.87277 & 570475 & 3970118 \\
\hline Horse Springs & 35 & Spring Mountains & 45.5 & -10.6 & -115.87083 & 36.29722 & 601388 & 4017507 \\
\hline Lost Cabin Spring & 36 & Spring Mountains & - & - & -115.65300 & 36.08300 & 621279 & 3993994 \\
\hline Peak Spring & 37 & Spring Mountains & 97.7 & -9.5 & -115.69736 & 36.26149 & 617019 & 4013739 \\
\hline Rainbow Spring & 38 & Spring Mountains & 73.4 & -9.6 & -115.50889 & 36.05278 & 634306 & 3990831 \\
\hline Borehole Spring & 39 & Tecopa Hot Springs & - & - & -116.23416 & 35.88608 & 569124 & 3971584 \\
\hline Tecopa Hot Springs & 40 & Tecopa Hot Springs & 2.00 & -6.30 & -116.23141 & 35.87191 & 569384 & 3970014 \\
\hline
\end{tabular}

${ }^{1}$ Sample is not charge balanced.

${ }^{2}$ Alkalinity value created. 
Table 11. Ranges of selected chemical parameters by water group, Lower Amargosa Valley and extra-basin contributing areas, California and Nevada.

$\left[\mathrm{HCO}_{3}\right.$, bicarbonate; mg/L, milligram per liter; pMC, percent modern carbon; TU, tritium units; $\mu \mathrm{g} / \mathrm{L}$, microgram per liter; $\mu \mathrm{S} / \mathrm{cm}$, microsiemens per centimeter; \%o, per mil; $\delta$, delta; ${ }^{\circ} \mathrm{C}$, degrees Celsius; - , no data available]

\begin{tabular}{|c|c|c|c|c|c|c|c|c|c|c|}
\hline Group name & $\begin{array}{c}\text { Number of } \\
\text { sites in group }\end{array}$ & $\begin{array}{l}\text { Water temperature } \\
\left({ }^{\circ} \mathrm{C}\right)\end{array}$ & $\begin{array}{c}\text { Specific conductance } \\
\left(\mu \mathrm{S} / \mathrm{cm} \text { at } 25^{\circ} \mathrm{C}\right)\end{array}$ & pH & $\begin{array}{c}\text { Alkalinity } \\
\left(\mathrm{mg} / \mathrm{L} \text { as } \mathrm{HCO}_{3}\right)\end{array}$ & $\begin{array}{l}\text { Calcium } \\
\text { (mg/L) }\end{array}$ & $\begin{array}{l}\text { Magnesium } \\
(\mathrm{mg} / \mathrm{L})\end{array}$ & $\begin{array}{l}\text { Sodium } \\
\text { (mg/L) }\end{array}$ & $\begin{array}{l}\text { Potassium } \\
\text { (mg/L) }\end{array}$ & $\begin{array}{l}\text { Chloride } \\
\text { (mg/L) }\end{array}$ \\
\hline Amargosa Canyon & 3 & $23-26$ & $1,000-1,300$ & $8.2-8.3$ & $290-380$ & $41-64$ & $30-43$ & $110-200$ & $22-25$ & $52-53$ \\
\hline Amargosa River & 4 & $10-21$ & $3,300-13,000$ & $7.5-8.9$ & $580-1,600$ & $12-58$ & $7.8-61$ & $660-3,100$ & $41-190$ & $300-1,800$ \\
\hline Ash Meadows & 6 & $27-34$ & $670-1,500$ & $6.9-7.6$ & $210-470$ & $1.6-50$ & $1.4-21$ & $39-300$ & $7.4-24$ & $20-49$ \\
\hline California Valley & 1 & 9 & 820 & 7.4 & 250 & 56 & 32 & 73 & 11 & 35 \\
\hline Chicago Valley & 2 & $19-27$ & $800-920$ & $7.6-8.4$ & $180-240$ & $24-43$ & $24-25$ & $76-110$ & $11-21$ & $46-54$ \\
\hline Greenwater Range & 1 & 12 & 310 & 8.3 & 130 & 6.9 & 0.96 & 63 & 1.3 & 14 \\
\hline Kingston Range & 1 & 11 & 480 & 6.9 & 240 & 13 & 23 & 60 & 2.6 & 65 \\
\hline Nevada National Security Site & 1 & 41 & 490 & 7.3 & 240 & 33 & 12 & 55 & 8.9 & 13 \\
\hline Pahrump Valley & 5 & $22-24$ & $320-530$ & $7.1-7.9$ & $110-230$ & $23-56$ & $19-36$ & $4.2-13$ & $1.1-2.0$ & $0.98-3.0$ \\
\hline Precipitation & 4 & - & - & - & - & - & - & - & - & - \\
\hline Shoshone and Tecopa & 6 & $21-38$ & $760-3,000$ & $7.6-10$ & $220-1,100$ & $0.30-43$ & $0.10-23$ & $85-690$ & $12-31$ & $46-140$ \\
\hline Spring Mountains & 4 & $4.7-15$ & $130-630$ & $7.4-7.8$ & $92-360$ & $31-65$ & $7.2-41$ & $0.79-18$ & $0.25-1.5$ & $0.45-12$ \\
\hline Tecopa Hot Springs & 2 & $39-44$ & $4,200-6,400$ & $8.6-8.7$ & $540-590$ & $2.3-3.8$ & $0.34-0.96$ & $760-850$ & $27-29$ & $530-570$ \\
\hline
\end{tabular}

\begin{tabular}{|c|c|c|c|c|c|c|c|c|c|c|}
\hline Group name & $\begin{array}{l}\text { Number of } \\
\text { sites in group }\end{array}$ & $\begin{array}{c}\text { Sulfate } \\
\text { (mg/L) }\end{array}$ & $\begin{array}{l}\text { Fluoride } \\
\text { (mg/L) }\end{array}$ & $\begin{array}{c}\text { Bromide } \\
\text { (mg/L) }\end{array}$ & $\begin{array}{l}\text { Silica } \\
\text { (mg/L) }\end{array}$ & $\begin{array}{c}\text { Arsenic } \\
(\mu \mathrm{g} / \mathrm{L})\end{array}$ & $\begin{array}{l}\text { Boron } \\
(\mu \mathrm{g} / \mathrm{L})\end{array}$ & $\begin{array}{c}\text { Lithium } \\
\text { ( } \mu \mathrm{g} / \mathrm{L})\end{array}$ & $\begin{array}{l}\text { Strontium } \\
(\mu \mathrm{g} / \mathrm{L})\end{array}$ & $\begin{array}{c}\text { Uranium } \\
(\mu \mathrm{g} / \mathrm{L})\end{array}$ \\
\hline Amargosa Canyon & 3 & $170-220$ & $2.3-3.0$ & - & $30-48$ & 20 & $1,000-1,900$ & - & $1,100-1,500$ & $2.4-8.4$ \\
\hline Amargosa River & 4 & $680-2,300$ & $2.0-6.4$ & $2.1-4.7$ & $43-65$ & $150-1,000$ & $7,900-20,000$ & - & $700-3,800$ & $14-18$ \\
\hline Ash Meadows & 6 & $79-140$ & $1.4-6.2$ & $0.005-0.15$ & $22-33$ & $10-120$ & $150-1,800$ & $84-90$ & $150-930$ & $2.0-3.2$ \\
\hline California Valley & 1 & 130 & 1.7 & - & 40 & 21 & - & - & 1,700 & 1.3 \\
\hline Chicago Valley & 2 & $100-120$ & $1.6-2.1$ & $<0.010$ & $24-65$ & $32-59$ & 1,400 & 130 & $980-1,000$ & $1.0-2.4$ \\
\hline Greenwater Range & 1 & 16 & 0.47 & 0.086 & 36 & 4.5 & - & - & 62 & 1.3 \\
\hline Kingston Range & 1 & 230 & 2.5 & 0.016 & 68 & 7.0 & 610 & 70 & 690 & 1.3 \\
\hline Nevada National Security Site & 1 & 33 & 0.75 & 0.24 & 29 & - & - & - & 200 & 3.1 \\
\hline Pahrump Valley & 5 & $24-56$ & $0.14-0.62$ & $0.011-0.04$ & $11-51$ & $0.50-8.0$ & $28-32$ & 4.9 & $340-1,500$ & $1.3-2.3$ \\
\hline Precipitation & 4 & - & - & - & - & - & - & - & - & - \\
\hline Shoshone and Tecopa & 6 & $100-240$ & $1.9-9.4$ & - & $34-96$ & $13-1,600$ & $1,400-130,000$ & - & $44-1,100$ & $1.2-5.7$ \\
\hline Spring Mountains & 4 & $2.4-120$ & $0.05-0.31$ & - & $4.1-20$ & $0.2-0.85$ & $8.6-110$ & 19 & $93-4,700$ & $0.64-2.1$ \\
\hline Tecopa Hot Springs & 2 & $570-610$ & $3.9-4.0$ & - & $84-91$ & $310-330$ & $9,200-11,000$ & 220 & $90-93$ & $6.6-7.1$ \\
\hline
\end{tabular}


Table 11. Ranges of selected chemical parameters by water group, Lower Amargosa Valley and extra-basin contributing areas, California and Nevada.-Continued

$\left[\mathrm{HCO}_{3}\right.$, bicarbonate; mg/L, milligram per liter; pMC, percent modern carbon; $\mathrm{TU}$, tritium units; $\mu \mathrm{g} / \mathrm{L}$, microgram per liter; $\mu \mathrm{S} / \mathrm{cm}$, microsiemens per centimeter; \% $\%$, per mil; $\delta$, delta; ${ }^{\circ} \mathrm{C}$, degrees $\mathrm{Celsius;} \mathrm{-} \mathrm{,} \mathrm{no}$ data available]

\begin{tabular}{|c|c|c|c|c|c|c|c|c|}
\hline Group name & $\begin{array}{c}\text { Number of } \\
\text { sites in group }\end{array}$ & $\begin{array}{c}\delta^{2} H \\
(\%)\end{array}$ & $\begin{array}{l}\delta^{18} 0 \\
(\%)\end{array}$ & $\begin{array}{l}\delta^{87} \mathrm{Sr} \\
(\%)\end{array}$ & $\delta^{87} \mathbf{S r} / \delta^{86} \mathbf{S r}$ & $\begin{array}{l}\delta^{234} \mathrm{U} \\
(\%)\end{array}$ & $\begin{array}{c}\text { C14 } \\
\text { (pMC) }\end{array}$ & $\begin{array}{l}\delta^{13} \mathbf{C} \\
(\%)\end{array}$ \\
\hline Amargosa Canyon & 3 & $-94.0--95.0$ & $-12.8--13.1$ & $4.53-11.4$ & $0.712-0.717$ & $1.92-3.10$ & - & - \\
\hline Amargosa River & 4 & $-81.1--91.9$ & $-9.10--12.0$ & 13.1 & 0.718 & 1.87 & - & - \\
\hline Ash Meadows & 6 & $-103--104$ & $-13.4--13.8$ & $3.40-4.98$ & 0.713 & 2.51 & $2.8-11$ & $-5.50--6.8$ \\
\hline California Valley & 1 & -93.8 & -12.6 & - & - & 3.80 & 34 & -7.00 \\
\hline Chicago Valley & 2 & $-95.5--96.0$ & -13.0 & 2.46 & 0.711 & 3.78 & 11 & -6.10 \\
\hline Greenwater Range & 1 & -87.4 & $-11.2--13.2$ & 3.50 & 0.712 & $1.93-2.78$ & 104 & -10.8 \\
\hline Kingston Range & 1 & -105 & -13.8 & 3.4 & 0.712 & 5.56 & 88 & -13.2 \\
\hline Nevada National Security Site & 1 & -108 & -14.0 & 5.26 & - & - & 2.2 & -4.70 \\
\hline Pahrump Valley & 5 & $-97.8--107$ & $-13.4--14.6$ & 0.36 & 0.709 & 2.29 & $6.9-51$ & $-7.12--8.80$ \\
\hline Precipitation & 4 & $-61.0--106$ & $-7.43--13.9$ & - & - & - & - & - \\
\hline Shoshone and Tecopa & 6 & $-93.0--100$ & $-12.2--13.3$ & $3.63-13.8$ & $0.712-0.719$ & $1.38-3.59$ & - & - \\
\hline Spring Mountains & 4 & $-88.5--99.6$ & $-11.9--13.4$ & 5.51 & 0.713 & $2.42-4.59$ & $45-98$ & $-9.60--10.6$ \\
\hline Tecopa Hot Springs & 2 & $-95.0--98.0$ & $-12.7--12.9$ & $10.5-11.3$ & 0.717 & $2.13-2.28$ & 2.0 & -6.30 \\
\hline
\end{tabular}



Publishing support provided by the U.S. Geological Survey Science Publishing Network, Sacramento Publishing Service Center

For more information concerning the research in this report, contact the Nevada Water Science Center

U.S. Geological Survey

2730 N. Deer Run Road

Carson City, Nevada 95819 


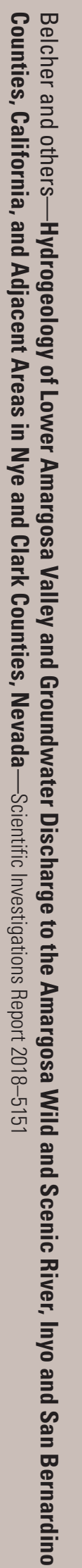

